\title{
Colaboración entre la Bibliotecología y los sectores productivos y económicos
}

ARIEL ALEJANDRO RODRIGUEZ GARCÍA

(coordinador)
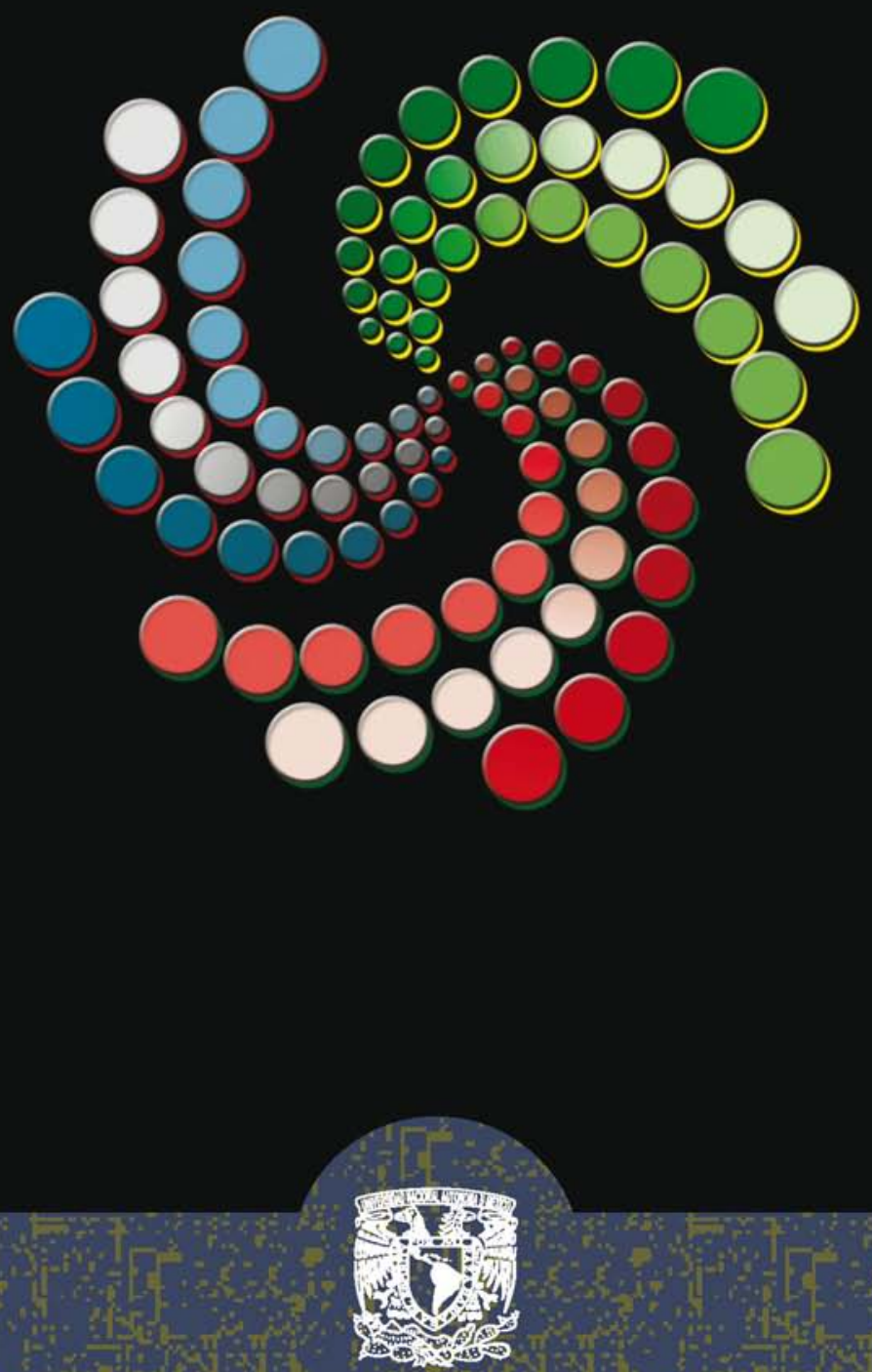


\section{La presente obra está bajo una licencia de:}

\section{http://creativecommons.org/licenses/by-nc-sa/3.0/deed.es MX}

\section{Atribución-No Comercial-Licenciamiento Reciproco 3.0 Unported}

Eres libre de:

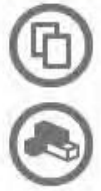

copiar, distribuir y comunicar públicamente la obra

hacer obras derivadas

Bajo las condiciones siguientes:

Atribución - Debes reconocer la autoría de la obra en los términos

especificados por el propio autor o licenciante.

No comercial - No puedes utilizar esta obra para fines comerciales

Licenciamiento Recíproco - Si alteras, transformas o creas una obra a

partir de esta obra, solo podrás distribuir la obra resultante bajo una licencia

igual a ésta.

\section{Esto es un resumen fácilmente legible del: texto legal (de la licencia completa)}

En los casos que sea usada la presente obra, deben respetarse los términos especificados en esta licencia.
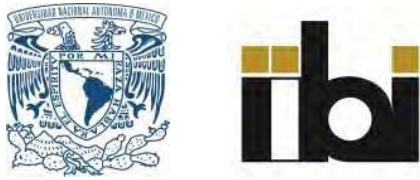
ב-

Colaboración entre la Bibliotecología

y los sectores productivos

y económicos 
COLECCIÓN

Sistemas Bibliotecarios de Información y Sociedad

Instituto de Investigaciones Bibliotecológicas y de la Información 


\title{
Colaboración entre la Bibliotecología y los sectores productivos y económicos
}

\author{
Coordinador \\ Ariel Alejandro Rodríguez García
}

Universidad Nacional Autónoma de México 2017 


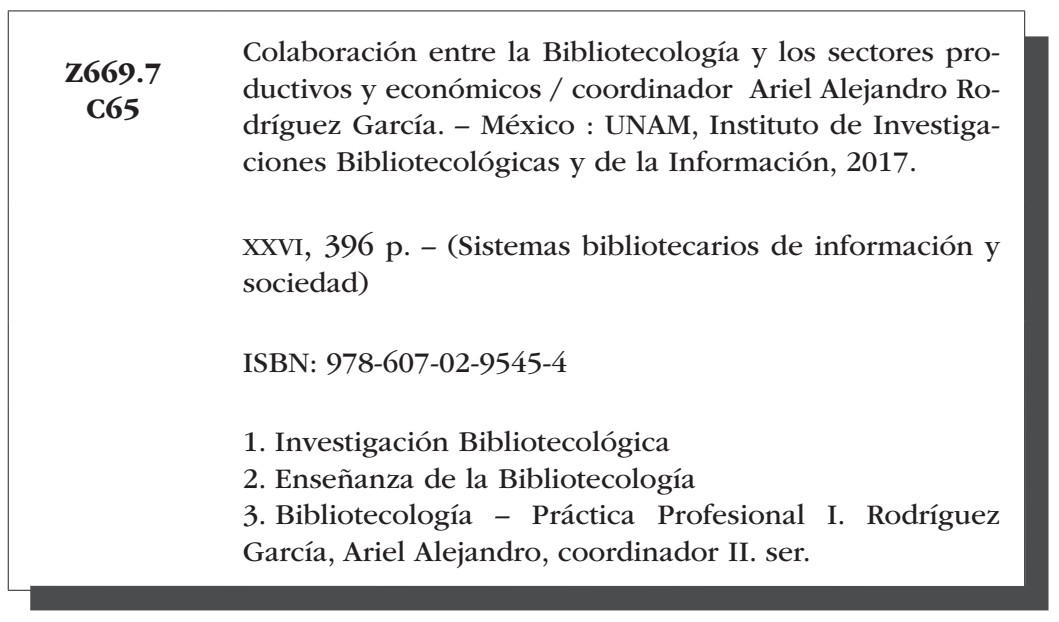

Diseño de portada: Mario Ocampo Chávez

Imagen de portada: Salvador Mendoza López

Primera edición, 2017

D.R. (C) Universidad Nacional Autónoma de México

Ciudad Universitaria, 04510, Ciudad de México

Impreso y hecho en México

ISBN: 978-607-02-9545-4 


\section{Tabla de contenido}

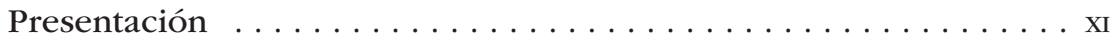

Ariel Alejandro Rodríguez García

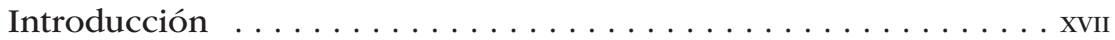

Adolfo Rodríguez Gallardo

Preservación digital de contenidos informativos

en medios de comunicación:

de la producción al archivo

De la PRODUCCIÓN AL ARCHIVO: UNA PERSPECTIVA DE

LA PRESERVACIÓN DIGITAL EN LA RADIO Y LA TELEVISIÓN . . . . . . . . . . 31

Perla Olivia Rodríguez Reséndiz

Preservación digital y confianza en los medios . . . . . . . . . . . 47

Juan Voutssás Márquez

LA IMPORTANCIA DE PRESERVAR EL PATRIMONIO

VIDEOGRÁFICO EN LOS ARCHIVOS DE TELEVISIÓN. . . . . . . . . . . . . 71

Ubaldo P. Candia Reyna

La industria de los contenidos

en el sector editorial

LA INDUSTRIA DE LOS CONTENIDOS EN EL SECTOR EDITORIAL:

CONTENIDOS, SOPORTES, MODELOS DE NEGOCIO, CREATIVIDAD E INNOVACIÓN . . 89

Jenny Teresita Guerra González

LA INDUSTRIA DE LOS CONTENIDOS EN EL SECTOR EDITORIAL.

UN CASO EN LA UNIVERSIDAD PÚBLICA . . . . . . . . . . . . . . . . 107

Edgar García Valencia 


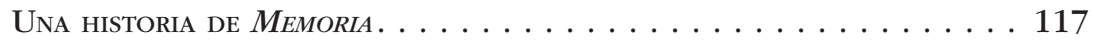
Jaime Ortega Reyna

Políticas de acceso a la información para el desarrollo social y económico

Política de ACCeso a la información PARA

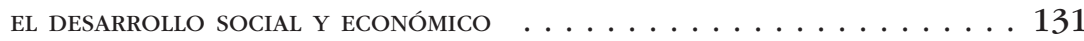
Egbert John Sánchez Vanderkast

LA INFORMACIÓN Y SU IMPORTANCIA EN PROCESOS POLÍtIICOS, ECONÓMICOS Y SOCIALES . . . . . . . . . . . . . . . . . . 149 Héctor Alejandro Ramos Chávez

DIFUSIÓN DE LA INFORMACIÓN: EXPERIENCIAS Y RETOS PARA APORTAR A LA DINAMIZACIÓN ECONÓMICA INCLUYENTE DE LOS TERRITORIOS RURALES . . . . . . . . . . . . . . . . . . . . 167

R. Antonio Riveros-Cañas y François Boucher

Recursos y servicios de información analógicos y digitales para los consumidores

RECURSOS DE INFORMACIÓN ANALÓGICOS Y

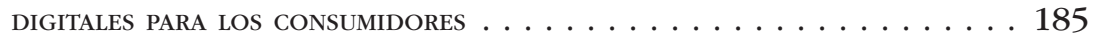
Brenda Cabral Vargas

EL USO DE LA INFORMACIÓN DESDE LA VISIÓN DEL CONSUMIDOR: la Profeco . . . . . . . . . . . . . . . . . . . . . . 195 Rodolfo García García

USO DE LA INFORMACIÓN POR LOS CONSUMIDORES Y FABRICANTES DEL SECTOR TEXTIL $\ldots \ldots \ldots \ldots \ldots \ldots \ldots \ldots$ Cinthya de Jesús Ríos Flores

EL CONSUMIDOR ANTE LOS PRODUCTOS Y SERVICIOS DE CONTENIDOS AUDIOVISUALES. . . . . . . . . . . . . . . 227 Francisco Esquivel del Reyo 


\section{La organización documental \\ en las industrias creativas}

LA ORGANIZACIÓN DOCUMENTAL EN

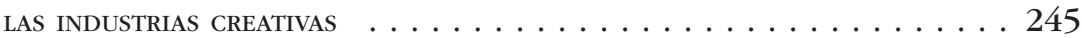

Catalina Naumis Peña

Industrias CREATIVAs. Cultura, MERCADo

Y LIBERTAD EN EL ENTORNO DIGITAL . . . . . . . . . . . . . 251

Raúl Trejo Delarbre

REPRESENTACIÓN TEMÁTICA DE

LOS NOTICIEROS EN LA WEB . . . . . . . . . . . . . . . . . . . . . 269

Silvano Soto Hernández

EL TEXTIL TRADICIONAL COMO

SOPORTE DE INFORMACIÓN.

SU ANÁlISIS Y ORGANIZACIÓN . . . . . . . . . . . . . . . . . . 293

Patricia Alejandra Méndez Zapata

Organización de la COLECCión FÍlmica

del programa Archivo Memoria de

la Cineteca Nacional . . . . . . . . . . . . . . . . . . 305

Hilda Gabriela Lobatón Cruz

El uso de la información en la alta gerencia

LA INNOVACIÓN EN LOS SERVICIOS Y EL USO

DE LA INFORMACIÓN EN LA ALTA GERENCIA . . . . . . . . . . . . . . . 327

Ariel Alejandro Rodríguez García

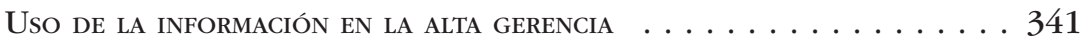

Kenia Olivera González

EL PROFESIONAL DE LA INFORMACIÓN Y SUS SERVICIOS

EN EL ANÁLISIS DE LA INFORMACIÓN FORMAL, INFORMAL

Y ANALÍtICA EN LAS CONFERENCIAS DE NEGOCIOS . . . . . . . . . . . . 351

María de Lourdes Nieto Ponce 
Investigaciones posdoctorales en el IIBI

USABILIDAD DEL SOFTWARE COMO INDICADOR DE LA INFORMATION LITERACY: UNA PROPUESTA PARA LA COMPRENSIÓN DE LA INTELIGENCIA EN

la ERA de la Información. . . . . . . . . . . . . . . . . . 365 Marco Brandão

Asociaciones E INSTITUCIONES CULTURALES:

el Caso de las bibliotecas en MéXico y

Argentina. Trayectos, hipótesis y problemas . . . . . . . . . . . . . . . 379

María de las Nieves Agesta 


\section{Presentación}

I 1 impulso y la intención de observar cómo se ha generado la colaboración entre nuestra disciplina y los sectores productivos y económicos surge de los objetivos prioritarios de "hacer del desarrollo científico, tecnológico y la innovación pilares para el progreso económico y social sostenible", y de hacer especial hincapié en el valor del conocimiento y la información como motor de la competitividad y del desarrollo a largo plazo. La tendencia mundial busca conectar a los grupos de investigación con los intereses comunes de la sociedad para la resolución de problemas prioritarios nacionales.

En este contexto, la información se erige como un factor productivo, y se convierte en el eje de la actividad económica mundial. Es decir, la industria de la información sobresale de entre todas las líneas de la actividad social y de trabajo. Su rasgo esencial es que el conocimiento es el fundamento para la producción en los capitales del primer mundo.

La gestión de la información no es exclusiva de los archivos y las bibliotecas, sino que es necesaria y se lleva a cabo en ámbitos y sectores muy diversos. Los modelos de 
gestión y administración de la información y el conocimiento que se utilizan en los sectores productivos y económicos son muy diferentes y tienen particularidades que posiblemente discrepen de los que habitualmente se conocen en las bibliotecas, centros de enseñanza u otras instituciones más presentes en los estudios bibliotecológicos y de la información.

Este libro es una muestra de la colaboración que se puede generar entre la bibliotecología y los estudios de la información con los sectores productivos y económicos. El tema principal es la gestión de la información y, hasta cierto punto, las derivaciones en la que ésta tiene en cada sector. Los temas que se analizan son los siguientes:

- El papel de la investigación y los problemas en la práctica bibliotecaria con énfasis en la desconexión entre ambos. Se invita a los investigadores a incursionar en la modalidad "investigación y desarrollo."

- La preservación digital de contenidos en la radio y la televisión. Plantea el problema en las emisoras de radio y televisión al destruir sus emisiones y con ello la herencia documental con fines educativos, científicos, artísticos y culturales. Por otra parte, se analiza la presencia de las Tecnologías de la Información y Comunicación en los procesos de producción. En la radio y la televisión, el rol de los archivos ha dejado de ser secundario y ahora es considerado un espacio estratégico para el advenimiento de los medios digitales.

- La industria de los contenidos -media and content industries- en el contexto anglosajón, nos lleva a mirar el sector editorial y la edición contemporánea a partir de sus contenidos, soportes y modelos de negocio (acceso abierto, suscripción, freemium y crowdfunding) y las experiencias y prácticas establecidas por editoriales independientes, así como el presente del libro digital. 
- El acceso a la información. Este tema plantea dos perspectivas, una es la de las sociedades cuya economía está basada en el conocimiento, y la otra se sitúa en su importancia en procesos políticos, económicos y sociales. Las sociedades que se soportan en la economía, perciben la cooperación como un factor importante. De ahí que se identifiquen tres dinámicas latentes que son: el dinamismo de la economía de mercado; la dinámica de la producción del conocimiento, y la gobernabilidad de las interfaces en los distintos niveles de la estructura del país. El acceso a la información asociado a la triple hélice, puesto en el contexto de la colaboración entre la bibliotecología y los sectores productivos y económicos, nos invita a reflexionar sobre las alianzas estratégicas y las interacciones entre las industrias y empresas transnacionales. El acceso a la información en los procesos políticos, es un aspecto fundamental de los valores democráticos de las naciones: la transparencia y la rendición de cuentas.

- Los recursos y servicios de información desde la perspectiva del consumidor son aspectos que ponen en la mesa de discusión la manera en que el consumidor satisface su necesidad de compra desde que se prepara para comprar, hasta que adquiere el bien o producto. El modelo de gestión de información que se genera en el proceso de compra muestra cómo las acciones, los deseos y los procesos emocionales y mentales, requieren de información, la cual deberá ser proporcionada y regulada por las fuerzas del mercado, y por los enfoques metódicos, razonados y formales que permitan enfrentar la complejidad dada por las variables involucradas en el proceso de compra.

- La primera discusión respecto a la organización documental en las industrias creativas se tuvo en el año de 1998. Varios países adoptaron el término y su conceptualización y con el paso del tiempo instituciones como la UNESCO clasificaron las 
industrias creativas en dos ramas: aquellas que están conectadas con alguna expresión cultural y las comerciales. Para la bibliotecología y los estudios de la información, los modelos de gestión desarrollados en esta industria son tan variados dada su diversidad de soportes, expresiones o tecnologías, que se preguntan acerca de los contenidos que están transitando a formatos digitales para hacerlos más asequibles a comunidades de usuarios más grandes. Los estudios de caso que se analizan de la industria creativa, conducen a la reflexión, por una parte, sobre cómo los noticieros televisivos nacionales utilizan el modelo propuesto por Van Djik respecto al análisis del discurso y el texto periodístico. Por la otra, el textil tradicional es revisado desde la perspectiva del análisis documental, donde se observa una forma compleja de revisión del contenido y la forma que tiene. Por otra parte, se aborda el estudio de las colecciones fílmicas, las cuales organizan la información a partir de dos pasos fundamentales: el inventario y la verificación técnica de los documentos visuales.

- El uso de la información en la alta gerencia. Los ejecutivos necesitan de información de valor para tomar decisiones; por este motivo, las estrategias de organización, búsqueda y recuperación de información deben ser tan específicas que inviten a la revisión de un modelo con base en evidencias y deben ser útiles en el sector empresarial y las conferencias de negocios. Ambos modelos surgen de encontrar soluciones para problemáticas operativas, nuevos retos en áreas específicas, para especializar a un grupo de ejecutivos. La alta gerencia vista desde la perspectiva bibliotecológica permite profundizar en la adecuación de los modelos de gestión de información con fines de maximizar los costos en beneficio de la inversión, por ejemplo, en las conferencias in-house.

- La usabilidad del software como indicador de la Information Literacy, así como el tránsito bibliográfico entre Argen- 
tina y México, son estudios que incursionan en dos aspectos muy diversos. El primero observa cómo la tecnología apoya la comprensión de la información desde diferentes sistemas y contextos, y su uso de manera eficiente. El segundo subraya que es momento de atender los estudios comparados latinoamericanos en materia de historia cultural, puesto que hay problemas comunes respecto a los orígenes de los sistemas bibliotecarios.

La utilidad principal de este texto será, esperamos, el desvelamiento de cómo los modelos de gestión y administración de la información en los sectores productivos y económicos se llevan a cabo con criterios específicos para la toma de decisiones que requieren de información organizada, normada y accesible. La necesidad de abordar el asunto de la colaboración bibliotecológica desde la información como un motor de competitividad y desarrollo, pareciera ser el eslabón que hacía falta para incursionar en la modalidad de investigación y desarrollo.

En suma, si nuestra actitud ante la colaboración entre la bibliotecología y los sectores productivos y económicos es positiva, habrá un obstáculo menos que vencer; si es negativa o confusa, será muy difícil emprender distintos retos que apoyen el desarrollo sostenible del país. Lo que ahora presentamos en este texto permitirá a las actuales y futuras generaciones conocer e involucrarse en modalidades de investigación y desarrollo. 


\section{Introducción}

¿Se puede conjuntar la práctica profesional con la investigación bibliotecológica?

T a pregunta que da título a este trabajo tiene la finalidad de llamar a la reflexión sobre la paradoja que parece presentarse en la labor de investigación; a saber, si los problemas que surgen en la práctica bibliotecaria deben ser resueltos por la investigación, o si se está ante dos asuntos totalmente distintos que son unidos en el marco de la misma disciplina. La pregunta, vista con cierta objetividad, parece una cuestión retórica con una respuesta clara y rápida: sí. Sin embargo, existe una serie de circunstancias que matizan esa respuesta, razón por la cual se estima conveniente comentar las tendencias que se observan en la literatura de la especialidad con la finalidad de brindar un panorama de lo que realmente ocurre.

He de confesar que el presente es el tercer documento que elaboro sobre el tema, y aclaro que esta insistencia es una inquietud personal surgida por mi genuino interés tanto en la investigación como en la implantación de servicios bibliotecarios. La aparente falta de relación entre los problemas surgidos en la práctica profesional y la investigación me ha 
llevado a discurrir y tratar de encontrar un área en la que se encuentren tanto los investigadores como los prestadores de servicios y que ambos se beneficien.

Este trabajo tampoco pretende examinar la epistemología de la bibliotecología, simplemente es una invitación a pensar en la interacción que debebría existir entre la práctica profesional y la investigación. Determinar en qué medida la investigación agrega desarrollos conceptuales a partir de los cuales se mejoran los servicios y se vuelven más eficientes es una tarea harto compleja pero impostergable. Este ensayo toma en consideración los cambios de paradigma de la educación bibliotecológica y la práctica profesional para argumentar su influencia en la investigación a través de un análisis breve y general de la literatura.

La enseñanza de la bibliotecología, tanto en Estados Unidos como en México, se basó en la transmisión de las buenas prácticas bibliotecarias. Antes del establecimiento de las escuelas, los bibliotecarios se entrenaban en las grandes bibliotecas y en ellas adquirían los conocimientos básicos para la realización de sus actividades al hacer énfasis en el desarrollo de colecciones. No fue sino muchos años después cuando, las escuelas de bibliotecarios se incorporaron a las universidades, que se intentó cambiar el enfoque de la educación por uno que contuviera las bases de la disciplina e hiciera hincapié en los servicios; de esta manera, algunos problemas bibliotecarios empezaron a tener un enfoque teórico.

Las escuelas de bibliotecología se enfocaron en lo que Shera llama el quadrivium: selección o desarrollo de colecciones, catalogación y clasificación u organización documental, referencia y administración de bibliotecas. A partir de la segunda parte del siglo pasado, se incluyó la tecnología, en particular aquella que utiliza la biblioteca en los servicios de referencia y en la administración. 
Algunas de las características de los planes de estudio de las escuelas en México eran las siguientes: un fuerte contenido práctico de las actividades que se realizaban en las bibliotecas la enseñanza de las mejores prácticas en el trabajo bibliotecario y el fomento de la cultura universal del estudiante, que tenía por objeto que el bibliotecario egresara con conocimientos generales que le permitieran interactuar con otros profesionales. En Estados Unidos se siguió una práctica general en los primeros años, pero con la incorporación de las escuelas a las universidades, los cursos quedaron en el nivel de College y la enseñanza de la bibliotecología se realizó en el nivel de maestría con una duración de dos años.

Con la enseñanza de la bibliotecología en las universidades, aumentaron las publicaciones. Tanto en la elaboración de tesis como en la producción de libros y artículos, se enfatizó en la difusión de prácticas bibliotecarias exitosas. Una parte importante de la producción escrita consiste en memorias de trabajos realizados para resolver una situación problemática en una biblioteca y la descripción del procedimiento empleado para ello. Esta forma de compartir las experiencias entre una biblioteca y otra, entre un bibliotecario y otro, ha nutrido la producción de notas en las revistas de bibliotecología.

Un buen número de revistas de la especialidad publican el resultado de las acciones emprendidas para resolver un problema puntual en una institución, las cuales difícilmente se pueden extender a otras instituciones, por lo tanto son difíciles de generalizar. No hay un planteamiento que busque dar respuesta a un problema de tipo universal; no se emplea una metodología de investigación en la cual exista un planteamiento especulativo o hipótesis. Estos trabajos permiten entender cómo ha sido el desarrollo de los servicios bibliotecarios en una institución y cómo se han operado 
los cambios en el curso del tiempo para simplificar los servicios o bien para volverlos más eficientes. Asimismo, permiten seguir el transcurso de la implementación tecnológica en las bibliotecas.

Tanto en Estados Unidos como en México, con el desarrollo de los programas de posgrado, el enfoque de la enseñanza, la elaboración de tesis y la producción de literatura especializada ha ido transitando hacia un fuerte contenido teórico y métrico.

Generalmente, las instituciones dedicadas a la investigación, así como las que se ocupan de la evaluación, tienden a dar mayor valor a la investigación teórica o básica en cualquier disciplina. Así, las que tienen una fuerte carga de práctica profesional como, por mencionar algunas, la medicina, la ingeniería y la bibliotecología, son subestimadas. Al decir esto, me refiero a que en México los ingenieros y los médicos, por seguir el ejemplo, que publican casos clínicos o bien productos derivados de lo que se llama "investigación y desarrollo" han sufrido para ser reconocidos como investigadores e incorporados al Sistema Nacional de Investigadores o a la Academia Mexicana de Ciencias. Si bien es cierto que los aportes de estos grupos se reconocen como productos de su práctica profesional, también lo es que no han sido valorados propiamente como contribuciones al desarrollo del conocimiento.

Todas las disciplinas tienden, a partir de sus investigaciones, a profundizar el conocimiento y fomentar el surgimiento de nuevas áreas del saber, del mismo modo que buscan comprobar si los resultados de una investigación pueden ser replicados con nuevos métodos de análisis. En todos los casos, un conocimiento reciente permite plantear el problema en otra dimensión, o bien una nueva tecnología puede producir un cambio importante en el conocimiento. 
El patrón de acción de las disciplinas científicas ha sido el mismo desde que se establecieron los protocolos de investigación. Dicho patrón es conocido como método científico. Los trabajos de investigación se valoran por la originalidad de sus planteamientos, su fortaleza metodológica e incluso por la revista en la que ha sido publicado, el número de citas que ha recibido y el impacto que ha tenido en su comunidad. Lo anterior forma parte del andamiaje en el cual se sustenta el trabajo académico de investigación original. También se piensa que la investigación debe contar con una fundamentación metodológica innovadora que permita comprobar que la investigación ha contribuido de una forma importante al avance de la disciplina.

La práctica que han seguido las investigaciones en bibliotecología y ciencias de la información, en especial en América Latina, ha sido fundamentalmente teórica. Lo anterior se comprueba al revisar los índices de las revistas especializadas en la disciplina, en los que se observa un fuerte énfasis en estudios teóricos sobre distintos temas. Es altamente probable que muy pocos bibliotecarios dedicados a la práctica profesional hayan recurrido de manera consistente a la literatura que se incluye en las revistas de mayor impacto de América Latina. En su práctica profesional, los bibliotecarios suelen buscar información en revistas que cubren el ejercicio profesional para satisfacer sus necesidades de información.

Lo mismo sucede con las tesis que se elaboran en los posgrados de América Latina. Los estudiantes, respaldados por sus tutores o directores de tesis, plantean y realizan trabajos con un fuerte contenido teórico; ocasionalmente éstos son elaborados con metodologías muy complejas o especializadas que limitan su utilidad y comprensión para los bibliotecarios no investigadores. 
La bibliotecología se mueve entre dos métodos diferentes en la investigación: el empleado por las ciencias duras y el usado por las ciencias sociales. La investigación basada en las llamadas ciencias duras suele consistir en el planteamiento del problema a investigar, la o las hipótesis que sustentan la investigación, el análisis que se hace de los resultados obtenidos en el laboratorio para comprobar o no las mismas, y, finalmente, las conclusiones. Por otra parte, la investigación en ciencias sociales, que también considera el planteamiento del problema, la hipótesis, el análisis de la información disponible y las conclusiones o comentarios finales, requiere en algunos casos establecer cuál es el marco teórico del trabajo. El marco teórico es una declaración de los principios filosóficos que se utilizarán en el análisis, pero muchas veces resulta más una profesión de fe que un trabajo académico.

La bibliotecología oscila entre estos dos métodos de investigación, pero aún no ha definido claramente en cuáles casos debe usar uno y en cuáles otro. Esta ambivalencia surge del deseo de que la bibliotecología sea considerada por un lado una disciplina científica que siga el método empleado por las ciencias naturales, y por el otro se reconozca a sí misma como una disciplina de las ciencias humanas y sociales.

Las revistas de investigación que publican trabajos con un carácter científico y que están alejadas de la práctica bibliotecaria, incluyen temáticas tratadas de modo especulativo, y en algunos casos los resultados de encuestas de opinión. En otros casos, se utilizan técnicas de medición de citas, factor de impacto e índice $\mathrm{H}$, que tienen como objetivo demostrar resultados científicos en cuanto que son cuantificables.

Si lo que se pretende es tener una disciplina que pueda contar con leyes generales del tipo de las ciencias naturales, 
con la clase de trabajos que se realizan no se puede lograr, pues por más que se usen metrías para estudiar algunos fenómenos bibliotecológicos, no se podrán establecer leyes generales. Y es que la disciplina bibliotecológica es del tipo social, por lo que explica los fenómenos a partir de una relación causa-efecto. Permítaseme ejemplificar lo anterior: sabemos que cuando la temperatura del agua baja de cero grados, ésta se congela. La observación de este fenómeno nos permite establecer una ley general: siempre que dejemos agua a la intemperie y la temperatura baje de cero grados, el agua se congelará, no importa en qué lugar del mundo suceda esto, si es de día o de noche, o si los habitantes de esa región tienen tales o cuales características. No sucede lo mismo cuando se dice que los usuarios necesitan tal o cual servicio y por ello no podemos llegar a una ley general. Se puede establecer una relación entre ese hecho y sus consecuencias, pero no decir que eso pasará en todas las bibliotecas.

Los viejos problemas de la bibliotecología, que durante muchos años preocuparon a los bibliotecarios, han sido dejados de lado. Los invito a que revisen los escritos publicados en las revistas latinoamericanas e identifiquen cuántos artículos están relacionados con los problemas de desarrollo de colecciones, organización documental, servicio de referencia y administración. El uso de la tecnología no puede servir de excusa, ya que la tecnología no resuelve por sí misma los problemas surgidos en la práctica bibliotecaria. Por ejemplo, los bibliotecarios no han decidido aún si los libros electrónicos deben estar registrados en los catálogos de la colección general de la biblioteca o deben estar en un archivo aparte; tampoco si deben usar las mismas reglas de catalogación o aplicar nuevos códigos de descripción documental. Cuando digo que no lo han decidido, es porque con frecuencia oigo opiniones de colegas que abordan el problema de distinta 
forma y no encuentran una definición clara de cuál es la mejor práctica. Los problemas en el área de consulta o referencia no han desaparecido, lo que ha sucedido es que los usuarios tienen mayor autonomía de búsqueda. Al respecto, el punto es determinar cuál debe ser la respuesta o posición que la biblioteca debe asumir ante tal situación: no debe esperar que los usuarios aprendan a buscar por sí solos en el mar de información que los abruma.

La biblioteca se enfrenta a una realidad modificada por la tecnología de la información en la que sólo se verá enriquecida si se incorporan adecuadamente esas tecnologías a sus servicios. Al decir incorporar, no me refiero a que los bibliotecarios entendamos cómo funciona la tecnología, sino a que los usuarios sepan cómo moverse adecuadamente en el torrente de información y, sobre todo, beneficiarse de ella.

Otro motivo de preocupación es el nulo énfasis que se da a los valores de la bibliotecología, tanto en los artículos de investigación como en los que trasmiten experiencias. La libertad de expresión, la oposición a la censura, la ética en el trabajo y el servicio como valores primordiales de la bibliotecología deben estar siempre presentes, ya sea que estemos prestando servicios o investigando.

Es necesario hacer hincapié en que el trabajo de investigación no debe estar subordinado al servicio; lo que se propone es que además de la teórica, se realice una investigación para el desarrollo de los servicios y, en consecuencia, que no se desdeñen los problemas que atañen al mismo. Es decir, hacer una investigación que no se quede en comunicar buenas prácticas, pero que tampoco haga estudios que no tienen una repercusión en la práctica profesional.

Para concluir, ilustraré la desconexión entre lo que sucede en el mundo de la práctica profesional y en el de la investigación observado el interior de nuestro querido Instituto. 
Hace más de dos años, la Dirección General de Bibliotecas de la unam puso a disposición de los usuarios de nuestra casa de estudios un servicio de descubrimiento de información (EDs por sus siglas en inglés). Este instrumento permite que el usuario realice mediante una sola búsqueda la consulta en todos los catálogos y bases de datos que antes estaban dispersos (librunam, tesiunam, seriunam, CLASE, PERIODICA y Scielo) y, al mismo tiempo, en las revistas que tiene suscritas y en los bancos de datos a los que la unam tiene acceso. Además, los resultados de la búsqueda pueden filtrarse por idioma, año de publicación y tipo de documento que se desea consultar sobre la base de un servicio 24/7 con acceso remoto a la información. Buena parte de los recursos están en texto completo. Esto no tendría gran importancia si no fuera porque la página de la biblioteca del IIBI no ofrece la oportunidad de utilizar el EDs, lo que significa que a más de dos años de la puesta en marcha de ese instrumento de búsqueda documental, los usuarios de la biblioteca del IIBI siguen buscando de una forma anticuada y limitada, a menos, claro, que consulten directamente la página bibliotecas unAm. Llama la atención que en la página de la biblioteca del IIBI, especializada en Bibliotecología y estudios de la información, no se haya incorporado ese servicio.

Lo que quiero indicar con las observaciones anteriores es que se percibe una desconexión entre los investigadores y el mundo de la prestación de servicios; en ningún caso se pretende decir que lo que se hace se hace mal. A mi modo de ver las cosas, tal disociación no debería existir. Los primeros en juzgar los nuevos servicios y proyectos implementados en el Sistema Bibliotecario de la uNAM deberían ser los investigadores del IIBI, de la misma forma en que los bibliotecarios al frente de los servicios deben encontrar en los investigadores, o al menos en algunos de ellos, aliados 
que profundicen en la temática de los servicios y propongan soluciones novedosas.

Me parece excelente que los investigadores del IIBI sigan desarrollando investigación teórica como lo han hecho hasta ahora, pero sería conveniente incursionar en la modalidad "investigación y desarrollo" con la implementación de un área o línea de investigación relacionada con los servicios que prestan las bibliotecas. La separación no beneficia ni a la investigación ni a la práctica profesional y, lo más importante, tampoco beneficia a los usuarios de la biblioteca.

Adolfo Rodríguez Gallardo 


\section{Preservación digital de contenidos informativos en medios de comunicación: de la producción al archivo}




\title{
De la producción al archivo:
} una perspectiva de la preservación digital en la radio y la televisión

\author{
Perla Olivia Rodríguez Reséndiz \\ Instituto de Investigaciones Bibliotecológicas y de la Información \\ UNAM
}

\section{INTRODUCCIÓN}

T os programas que han sido transmitidos a través de la radio y la televisión, así como los contenidos publicados en Internet, forman parte de la era mediática (Hoog, 2005). Estos documentos son parte de la herencia documental de la sociedad y, además, son recursos de información para la educación, la ciencia, el arte y la cultura.

Durante muchos años, la radio y la televisión almacenaron, en el mejor de los casos, miles de soportes analógicos. Es sabido que una parte de las producciones radiofónicas y televisivas se destruyeron, tiraron a la basura y deterioraron por el olvido y la falta de valoración como patrimonio. Inclusive, se ha documentado que los programas, una vez que fueron emitidos, se borraron y reutilizaron en la producción de nuevas series. La carencia de recursos económicos para comprar cintas derivó en esta práctica. El reuso de los soportes fue una dinámica recurrente entre los productores de programas de radio y televisión. Por ello, no hay evidencia 
documental de muchas grabaciones y se perdió una gran cantidad de programas que sólo salieron al aire una vez. La poca importancia que las emisoras mostraron hacia sus archivos fue un común denominador en prácticamente todo el mundo. "Las empresas de televisión se concentraban en las áreas de programación, mientras que el archivo era algo lleno de polvo, sin atención" (Estrada, 2001: 295). En la radio, el archivo era el área menos relevante en la producción. Inclusive, durante mucho tiempo se confinó al personal conflictivo al archivo.

Los archivos en la radio y televisión se desarrollaron después del inicio de transmisiones del medio; en algunos casos, fueron unos cuantos años y, en otros, décadas, probablemente porque se desconocía el valor de la producción más allá de su transmisión y porque no se pensaba en retransmitir las series. Los primeros archivos se crearon sobre todo en grandes medios públicos de comunicación. Son muy pocas las emisoras que conservan la totalidad de sus producciones. Algunas de las principales corporaciones de medios públicos que preservan una cuantiosa cantidad de grabaciones son, entre otras, la British Broadcasting Coorporation (BBC) de Londres; la Radio Televisione Italiana (RAI); la Nippon Hoso Kiokai (NHK) de Japón; Radio Netherland; Norwegian Broadcasting Corporation (NRK); Radio Francia Internacional (RFI); Radio Televisión Española (RTVE). Hay casos ejemplares, como el Instituto Nacional del Audiovisual de Francia (INA), una institución que conserva toda la producción de televisión (Saintville, 1986). Por su parte, la $\mathrm{BBC}$ de Londres resguarda una "gran colección de su propia producción, pero sobre todo cubre el periodo después de la II Guerra Mundial" (Hanford, 1986: 32). La mayoría de las estaciones de radio y televisión conservan las producciones recientes, a partir de la década de los setenta. 
En un principio, los archivos televisivos fueron considerados como "centros de recursos para la televisión y se fueron poco a poco estructurando y dotando de medios económicos, técnicos y de personal, todos ellos adaptados a una auténtica política de conservación" (Saintville, 1986: 26). Esta situación fue similar para los archivos de radio.

El reconocimiento del valor patrimonial y documental de los archivos sonoros y audiovisuales (Unesco, 1980) sentó las bases para emprender las tareas de rescate y para que se iniciaran los proyectos pioneros de digitalización. Además, modificó la perspectiva que se tenía del archivo en la radio y la Televisión, medios en los que era considerado como una bodega para el almacenamiento de cintas y como el área de menor importancia dentro del canal o la estación de radio.

INCORPORACIÓN DE LAS TECNOLOGÍAS

DE INFORMACIÓN Y COMUNICACIÓN

La entrada al mundo digital a través de la incorporación de las tecnologías de información y comunicación (TICs) en los procesos de producción de radio y televisión modificó y ensanchó las posibilidades de los medios. Asimismo, fortaleció y dio visibilidad a los archivos.

Además de la incorporación de computadoras para llevar a cabo las tareas administrativas y de gestión, el primer cambio notorio se dio en la producción. La producción digital desplazó a la analógica desde mediados de los años noventa, cuando comenzó la producción radiofónica sin cintas (Frilander, 2006). Al principio, esta nueva modalidad era muy lenta porque los operadores debían familiarizarse con el uso de las nuevas herramientas informáticas. Los operadores técnicos tuvieron que capacitarse y aprender nuevas habilidades. 
Los más jóvenes se adaptaron, en la mayoría de los casos, de inmediato; los de mayor edad, en muchas ocasiones, decidieron jubilarse o bien, desarrollar otras funciones. El aprendizaje de las innovadoras tecnologías de grabación y edición digital provocó que, en algunos casos por la falta de pericia, se perdieran los materiales grabados porque no se habían guardado correctamente. Ante tal situación, el programa debía ser grabado de nuevo.

El productor, por su parte, estaba ante una nueva herramienta de creación que desconocía. En la radio, esta situación provocó que se cuestionara y negara la utilidad que tenía la producción digital. Por ello, durante muchos años se hizo una producción híbrida analógica y digital. Fueron muy pocos los operadores y productores que se aventuraron de inicio a producir en entornos digitales. Con el paso del tiempo, los operadores y productores reconocieron que la producción digital aportó una amplia gama de posibilidades a la radio y la televisión.

La transición de la producción analógica a la digital coincide con una serie de discusiones en foros internacionales en torno a la transferencia de contenidos grabados en una amplia gama de soportes analógicos a plataformas digitales a través de la digitalización.

Los responsables de los archivos sonoros y audiovisuales se dieron cuenta de que "la intención del clásico paradigma de conservar el material original era un esfuerzo en vano debido a la inestabilidad de los carretes o contenedores, así como a la futura carencia de algunos equipos de reproducción altamente sofisticados" (Schüller, 2006: 90). La conservación de los contenidos y no de los soportes fue la idea clave de la preservación y, para ello, fue necesario transferir los contenidos grabados en soportes analógicos a plataformas digitales a través de la digitalización. Ésta fue 
una medida estratégica ante el advenimiento de nuevos medios digitales y la creación de nuevos servicios y productos de información digital. La radio fue pionera en digitalizar colecciones de medios audiovisuales de comunicación. En 1992, el ingeniero Albrecht Haefner tuvo a su cargo el primer proyecto para digitalizar las colecciones radiofónicas de la swr (Südwestrundfunk) de Alemania. Después de esta experiencia, otras emisoras de radio y televisión emprendieron la digitalización de sus colecciones.

El ímpetu por digitalizar la mayor cantidad de grabaciones llevó, en el caso de la radio, a que se cometieran errores, algunos de los cuales fueron insalvables. Se "digitalizaron" cientos de programas en formatos de compresión y se guardaron en discos compactos. Una vez que se establecieron consensos técnicos entre grupos de investigadores y especialistas, entre otros de la Asociación Internacional de Archivos Sonoros y Audiovisuales (IASA) y de la Association for Recorded Sound Collections (ARSC, 2011), en relación con los parámetros y formatos consensuados de digitalización, y que se demostró que el disco compacto no era un soporte estable (Bradley, 2006), fue necesario volver a digitalizar estos materiales.

Las primeras experiencias de digitalización fueron ensayos de prueba y error. Se desconocía cómo poner en marcha la tecnología y los procesos fueron innovadores y complejos para los archivos. No obstante, tras los primeros tropiezos, la digitalización fue formulada como una necesidad inminente en el naciente entorno digital. De acuerdo con Frilander (2006), las razones por las cuales la Yle (Compañía Finlandesa de Radiodifusión) emprendió la digitalización fueron la incorporación de materiales digitales, el deterioro de los soportes antiguos y la necesidad de reutilizar materiales y permitir el acceso en el menor tiempo posible sin importar su ubicación. 
La tecnología digital representó un cambio "muy importante en el papel que desempeña un archivo de difusión. Anteriormente, todo mundo mandaba las cintas y los documentos al archivo central [...] ahora tenemos información en servidores individuales, productos o programas que pueden ser gestionados [...] para manejar la información en forma digital" (Malden, 2009: 63). El archivista debe preservar a largo plazo la información generada en los medios y, al mismo tiempo, atender las necesidades inmediatas de información para la producción de noticias y programas. "El archivo debe responder a este reto y necesita desarrollar una nueva función, mediar entre el personal de la difusora que maneja el contenido y satisfacer las necesidades del archivo" (ídem).

Las ventajas formuladas en los proyectos pioneros de digitalización estuvieron orientadas a señalar que este nuevo proceso enriquecería la producción al dar acceso a todos los documentos en cualquier momento y desde cualquier lugar, al permitir consultar un mismo documento en dos áreas de producción, y al reducir el tiempo en que se hicieran las copias. Además, la disposición para tener acceso a un archivo no estaría determinada por el horario de trabajo del archivista, se podría consultar 24 horas, los 365 días del año. Se evidenció la disminución de costos de operación en el archivo al reducir el espacio destinado para el almacenamiento, eliminar el uso de la estantería e incluso se señaló que se reduciría el staff. Asimismo, se puso en valor la alta velocidad de datos, rápida transferencia de archivos, alta capacidad de almacenamiento y la estandarización de los formatos de grabación (Haefner, 2002). Las desventajas señaladas se centraron sobre todo en el alto costo que implicaba la puesta en marcha de un proyecto de digitalización y la complejidad de su operación, debido a que se incorporarían nuevos procesos documentales inexplorados hasta entonces. 
Desde que iniciaron los primeros proyectos de digitalización hasta ahora, éstos se han desarrollado de forma disímiles en el mundo. Mientras que en Estados Unidos, Europa, Japón y Australia, entre otras regiones, se han alcanzado avances notables, en otros lugares, una gran parte de las colecciones sonoras y audiovisuales están en riesgo de perderse en los próximos años. Hace más de una década, Emmanuel Hoog, Presidente de la Federación Internacional de Archivos de Relevisión señaló: "Sólo los países ricos lograrán salvar una parte de su memoria-imagen. Latinoamérica, África, el Medio Oriente y Próximo Oriente, el Sureste Asiático no serán capaces de movilizar los recursos necesarios para asegurar la gran migración: transformar en digital todo este acervo analógico" (2005: 3-4). A una década de que Hoog advirtiera que el patrimonio audiovisual está en riesgo de desaparecer, recientemente se ha establecido la fecha límite para poder digitalizar y, con ello, preservar este patrimonio. El National Film and Sound Archive de Australia (2015) señaló, con base en un consenso internacional de archivos audiovisuales, que el año 2025 es la fecha límite para poder digitalizar las grabaciones que se hicieron en cintas magnéticas. Después de esta fecha, la obsolescencia y el deterioro de las grabaciones impedirán que se puedan volver a escuchar y ver una parte de los sonidos y las imágenes en movimiento que han narrado la historia contemporánea.

Esta declaración resulta relevante sobre todo para la industria de la radio y la televisión, que ha grabado la mayor parte de sus programas en cintas magnéticas. La cinta magnética es un soporte tecnológico que fue utilizado para grabar audio y video a partir de 1950 (National Film and Sound Archive, 2015). Ésta tuvo un uso industrial y casero. En la industria de la radio y la televisión, tuvo un uso relevante. Una gran parte 
de los programas de radio fueron grabados en cintas de carrete abierto (Ampex, Scotch, Basf, entre otras) y casetes, en tanto que algunos programas de televisión en videocasetes (U-Matic, Betamax, Betacam, Betacam SP, entre otros). Las cintas magnéticas han tenido un desgaste sistemático debido a su uso continuo y a su paso en las máquinas para grabación, lectura o limpieza, así como por el deterioro ocasionado por condiciones inadecuadas de conservación y por la composición "química y física que favorece la oxidación y la hidrólisis [...] otro ejemplo más es el tristemente célebre síndrome de vinagre, esa acidez que corroe los sonidos y que afecta ya al 40\% del material" (Hoog, 2005: 4).

Aun cuando el énfasis se ha puesto en los soportes de cintas magnéticas, el riesgo de pérdida atañe a todos los tipos de documentos. De acuerdo con Schüller, todos los documentos audiovisuales son propensos a deteriorarse debido "a la inestabilidad química de sus respectivos materiales: el celuloide se deteriora con el limo o polvo; las capas de información de discos instantáneos se vuelven quebradizas y se descaman; [y] muchas cintas magnéticas se dañan por el colapso de las capas de pigmentos, haciendo difícil su reproducción y, en ocasiones, imposible" (2006: 88).

Se dispone de menos de una década para digitalizar los programas de radio y televisión que han sido grabados en cintas magnéticas. De no hacerlo, una parte de la herencia intangible creada por estos medios de comunicación se perderá irremediablemente.

\section{LA PRODUCCIÓN Y LA PRESERVACIÓN DIGITAL}

De forma paralela al desafío que representa hacer frente al riesgo de pérdida de los contenidos que fueron grabados en soportes analógicos, la industria de la radio y la televisión 
enfrenta otro reto: la salvaguarda de una gran cantidad de documentos cuyo origen es digital. La producción de documentos de origen digital es cuantiosa y variada. La radio produce día a día decenas de horas de materiales en frío, noticiarios, crónicas, entrevistas, entre otros programas dirigidos a diferentes públicos. Por su parte, la televisión graba imágenes de stock, entrevistas, noticiarios, comerciales, programas de una amplia gama de temas, etcétera. Los documentos de origen digital se producen y transmiten a través de tecnología digital (Bamberger, Rob y Brylaswky, 2010) en los nuevos medios digitales, también denominados nuevos medios o sencillamente medios digitales (Lister, M. et al., 2003).

La industria de la radio y la televisión se ha expandido y diversificado a través del advenimiento de los nuevos medios digitales, que han traído consigo una serie de cambios en la forma tradicional de producir, distribuir y usar los contenidos. Estos cambios no son sólo tecnológicos, también son textuales, convencionales y culturales. Los nuevos medios son digitales, interactivos, hipertextuales, dispersos y virtuales (Lister, M. et al., 2003).

Para definir los nuevos medios digitales, Cebrián (2009) emplea el término cibermedios. Los cibermedios difieren de los medios tradicionales, pero no son radicalmente opuestos, hay vínculos entre unos y otros (idem). Los cibermedios o nuevos medios digitales se generan por la convergencia de tecnologías. Es decir, "todos se integran en el lenguaje digital para el tratamiento por las máquinas, pero para la percepción y seguimiento de los usuarios, aparecen con sus correspondientes representaciones simbólicas: escritas, sonoras, visuales, audiovisuales, que son los modos como el ser humano puede percibirlas" (ibidem:19). A través de la convergencia se integran lenguajes, tecnologías y 
estrategias. La Internet es la plataforma en la cual convergen, se difunden y se distribuyen las señales de cable, satélite, ondas hertzianas y su correspondiente web (Cebrián, 2009) de la industria de la radio y la televisión.

Es notorio que la radio (amplitud modulada y frecuencia modulada) y la televisión (abierta y por cable) pierden presencia frente al advenimiento de nuevos medios digitales. "El consumo de contenidos audiovisuales [y sonoros] se ha visto favorecido tanto por la masificación de los dispositivos inteligentes (televisores, smartphones y tablets) como por el actual entorno de creciente conectividad que favorece la transmisión de datos a mayor y más veloces capacidades" (González, 2016). En el caso de la televisión, plataformas como YouTube, Netflix y Claro Video, entre otras, están ganando a los televidentes que, ante la falta de creatividad en los contenidos, flexibilidad en horarios de transmisión y el exceso de comerciales que interrumpen la narrativa y discurso audiovisual, buscan nuevas propuestas programáticas. La generación de jóvenes que tienen entre 20 y 35 años, prende menos la televisión y consume más contenidos audiovisuales a través de plataformas digitales. "La población con poder adquisitivo y juvenil tiende a ser la más favorecida por los anunciantes. Sin embargo, hay una tendencia hacia el envejecimiento de la población; los espectadores de más edad ven en promedio más televisión al día que los jóvenes" (PwC, 2015:17).

En el caso de la radio, este medio se ha ensanchado a través de la ciberradio con la incorporación de chats, foros y email para la retroalimentación con la audiencia, pero sobre todo a través del podcasting, los audioblogs (Cebrián, 2009) y el streaming on line. En este contexto, se observa el desplazamiento de la radio de amplitud modulada (АM) por la ciberradio o radio por Internet (PwC, 2015). Esta tendencia explica por qué se escuchan más plataformas como Spotify 
que la radio (López, 2016). Las nuevas plataformas digitales sonoras no sólo transmiten los tradicionales contenidos que la radio emite desde hace más de un siglo, también han incursionado en ofrecer a las personas diversidad, mejor calidad de audio y una manera más directa de llegar al radioescucha. Además, ponen a disposición de la audiencia una mayor cantidad de contenidos. En el entorno de producción de nuevos medios digitales, los materiales de archivo adquieren notoriedad e importancia porque pueden ser reutilizados para ser transmitidos nuevamente y pueden crear innovadores servicios y productos de información sonora y audiovisual. Por ello, la preservación digital, a diferencia de la preservación de contenidos analógicos, gana terreno y se integra de manera progresiva en el sistema de producción digital radiofónica y televisiva.

Si la preservación de las colecciones analógicas que durante varias décadas ha producido la industria de la radio y la televisión es una tarea compleja, la incorporación de documentos de origen digital suma nuevas dificultades. La preservación de programas, grabaciones en frío y materiales que no han sido transmitidos cuyo origen es digital presenta muchas diferencias con la tradicional forma de mantener los contenidos de los videotapes (Howard Besser, Karen Cariani y Kara Van Malssen, 2010).

Por ello, tratar de conservar grandes cantidades de contenidos digitales puede ser desalentador y preocupante. Sobre todo cuando los archivistas están conscientes de que ante los tradicionales problemas de obsolescencia y deterioro, los documentos de origen digital presentan nuevos retos, y de que las técnicas para el control de temperatura y humedad, el monitoreo técnico y el copiado como medida de conservación que se emplearon con los documentos analógicos dejan de ser relevantes para los documentos digitales (ídem). 
La esperanza de vida de un documento sonoro o audiovisual de origen digital es más corta que la de un documento analógico. Su riesgo de pérdida es alto y el cambio y actualización del soporte digital en que está contenido, como medida de preservación, debe llevarse a cabo en ciclos más cortos que los utilizados en los analógicos. De manera contraria a lo que sucedía en la producción analógica, las tareas de preservación de un documento cuyo origen es digital no pueden quedarse al final del ciclo de producción. La preservación digital debe formar parte de toda la cadena de producción en la radio y televisión, desde el momento en que una serie es autorizada para ser producida. Este hecho modifica la situación del archivo dentro del canal de televisión o bien la estación de radio. El archivo debe ser parte integral y estratégica de la producción radiofónica y televisiva.

\section{Conclusiones}

Los archivos de la industria de la radio y la televisión han pasado de tener un rol secundario en las actividades de los canales y estaciones, a ser valorados como espacios estratégicos ante el advenimiento de los nuevos medios digitales. Se necesitan más contenidos y los archivos los tienen; para ello deben ser digitalizados. Para llevar a cabo esta tarea se dispone de menos de una década. La preservación digital de las colecciones que han producido la industria de la radio y la televisión no es una tarea aislada que compete sólo al archivista, es un área estratégica en la radio y la televisión, sobre todo ante la presencia y desarrollo de los nuevos medios digitales. Se necesita producir más y mejores contenidos, y en esta tarea los archivos pueden ser recursos de apoyo a la creación de nuevas series. Además, pueden 
ser reutilizados para generar programaciones a la carta de acuerdo con las necesidades de las audiencias. Un programa de radio y televisión una vez emitido no pierde su valor; al contrario, inicia una cadena de valor que debe ser sostenida a largo plazo. Por lo tanto, el vínculo entre la producción y la preservación digital debe ser la base que alimente los nuevos medios digitales.

\section{Bibliografía}

ARSC-Technical Committee (2011). Study of Embedded Metadata Support in Audio Recording Software. Association of Recorded Sound Collections. Disponible el 29 de noviembre de 2016 en: www.arsc-audio.org/pdf/ARSC_TC_MD_Study.pdf.

Bamberger, R. y S. Brylaswky (2010). The State of Recorded Sound Preservation in the United States. Estados Unidos: Council on Library and Information Resources / The Library of Congress.

Besser, H., K. Cariani y K. Van Malssen (2010). Six Strategies for Sustainable Preservation of Born Digital Public Television. A Report by the Preserving Digital Public Television Project Part of the National Digital Information Infrastructure and Preservation Program (NDIIPP) of the Library of Congress. Estados Unidos: Library Congress.

Bradley, K. (2006). Riesgos asociados con el uso de los discos compactos (CDs) y videodiscos (DVDs) como medios confiables de almacenamiento para colecciones de archivo. México: Unesco / Fonoteca Nacional. 
Cebrián, M. (2009). "Comunicación interactiva en los cibermedios”. Comunicar, 16 (33), 15-24. Disponible en: http://doi. org/10.3916/c33-2009-02-001.

Estrada, L. (2001). "Avances tecnológicos en el ámbito de la televisión”. En P. Rodríguez (coord.). Memorias del Primer Seminario Internacional de Archivos Sonoros y Audiovisuales. México: Conaculta.

Frilander, J. (2006). "Experiencias prácticas de control de un archivo digital en el ámbito de la radiodifusión”. En IASA, El significado educativo y cultural de los archivos audiovisuales. México: Radio Educación.

González, S. (2016). "Servicios de video por Internet desplazan tv de paga o abierta". La Jornada en línea. Disponible el 29 de noviembre de 2017 en: http://www.jornada.unam. $\mathrm{mx} / 2016 / 05 / 08 /$ economia/017n2eco.

Haefner, A. (2006). "Strategies and Preservation Policies in the Radio Archive of the German Public Broadcaster SWR". Memorias del primer seminario internacional Los Archivos Sonoros y Audiovisuales en América Latina. México: Radio Educación.

Hanford, A. (1986) "Los archivos de televisión: Conservación y acceso en el Reino Unido". En Panorama de los Archivos Audiovisuales: contribución a la puesa al día de las técnicas de archivo internacionales (31-34) Madrid: Federación Internacional de Archivos de Televisión.

Hoog, E. (2005). ¿Guardar todo? Los dilemas de la memoria en la Edad Mediática. México: Radio Educación.

Lister, M. et al. (2003). New Media: A Critical Introduction. Nueva York: Routledge.

López, J. (2016). "Spotify, la tercera estación de radio más escuchada". El Financiero en línea. Disponible el 28 de noviembre de 2016 en: http://www.elfinanciero.com.mx/tech/spotify-la-tercera-estacion-mas-escuchada.html. 
Malden, S. (2009). "La salvaguarda de los archivos digitales en la sociedad de la información”. En P. Rodríguez. La salvaguarda del patrimonio sonoro y audiovisual: un reto mundial. México: Conaculta.

National Film and Sound Archive. (2015). Deadline 2025. Collections at Risk. Australia. Disponible el 29 de noviembre de 2016 en: http://www.nfsa.gov.au/site_media/uploads/file/2015/10/29/ Deadline_2025_Collections_at_risk.pdf.

PwC (2015). Entertainment and Media Outlook México 2015-2019, $1-48$.

Saintville, D. (1986). "La conservación de las imágenes en movimiento en Francia". En Panorama de los Archivos Audiovisuales: contribución a la puesa al día de las técnicas de archivo internacionales (25-30) Madrid: Federación Internacional de Archivos de Televisión.

Schüller, D. (2006) "La preservación de la herencia digital". En P. Rodríguez, (comp.) Memorias del tercer seminario internacional. La preservación de la memoria audiovisual en la sociedad digital. México: Conaculta.

Unesco (1980). Recomendación sobre la salvaguardia y la conservación de las imágenes en movimiento. Disponible en: http:// portal.unesco.org/es/ev.php-URL_ID=13139\&uRL_DO=DO_TOPIC\&URL_SECTION=201.html. 


\title{
Preservación digital y confianza en los medios
}

\author{
JuAn VouTssás MárQuez \\ Instituto de Investigaciones Bibliotecológicas y de la Información \\ UNAM
}

"El problema con las citas e información

encontradas en la Internet

es que no todas son verdaderas".

Abraham Lincoln

$\mathrm{U}$

no de los signos de la sociedad contemporánea es, sin duda, el incremento en la producción documental. A tal grado se manifestó este fenómeno, que se convirtió en el denominador de esta sociedad: la sociedad de la información. No existe nada en el mundo que crezca al mismo ritmo que la información, no hay ninguna otra actividad, industria, concepto, subproducto, etc., que haya crecido al ritmo en que lo ha hecho la información en las últimas décadas. A causa de esta sobreabundancia, existe una tendencia a que las personas y las organizaciones contemporáneas consuman cada vez más y más información de todo tipo: noticias, TV, radio y cine; sitios web, blogs, publicaciones de toda índole - libros, revistas, diarios, mapas, catálogos, música, etc., principalmente electrónicas-; redes sociales, chats, mensajería, juegos electrónicos, llamadas telefónicas o videollamadas, etcétera. 
De acuerdo con la organización IDC, el mundo produjo 130 exabytes de información en 2005; 1,227 exabytes en 2010; 2,837 exabytes en 2012 ; 8,591 exabytes en 2015 , y proyecta que se producirán 40,026 exabytes en 2020. ${ }^{1}$ De acuerdo con el sitio Worldometers, ${ }^{2}$ en el año 2016 se publicarán en el mundo poco menos de 2 millones de títulos de libros y algo más de 1.5 millones de artículos en revistas; un día cualquiera, a finales de 2016, se publicaron 4 millones de entradas de blogs, además de 300 millones de ejemplares de diarios.

De esa gran producción y consumo de información se deriva una problemática cuya tendencia también es a incrementarse: el cuestionamiento de la calidad y credibilidad de la información que se consume. Cada vez más consumidores se encuentran con información tendenciosa, sesgada o inclusive falsa, y cada vez se preguntan más hasta qué grado confiar en la información a la que acceden, pues evidentemente existen problemas derivados de creer en información que no es fidedigna y de las consecuencias que esto acarrea, así como también existen problemas derivados de dudar de la información recibida cuando es veraz. Esto significa que, en la medida en que la producción y el consumo de la información se incrementa, crecen también los problemas de "confianza" o "desconfianza" en esa información: "[...] el gran enemigo de la verdad no es la mentira deliberada, urdida y deshonesta, sino el mito persistente, persuasivo, e irreal... sometemos los hechos a un conjunto prefabricado de interpretaciones. Nos gusta la

11 exabyte $=1000$ petabytes $=1$ '000,000 terabytes $=1$ '000,000,000 gigabytes $=1$ '000,000,000,000 megabytes $=10^{* * 21}$ bytes o caracteres. John F. Ganz y David Reinsel (2012). "The Digital Universe in 2020". IDC (International Data Corporation). Sponsored by EMC Corporation. Diciembre 2012. Disponible en: http://www.emc.com/collateral/analyst-reports/idc-the-digital-universe-in-2020.pdf

2 http://www.worldometers.info. 
comodidad de la opinión sin la incomodidad de la reflexión [...]" (Kennedy, 1962).

Confianza es un término muy utilizado pero difícil de definir. La principal dificultad consiste en que hay muchos puntos de vista desde los cuales se puede abordar este concepto, según el campo desde el que se estudie: filosofía, sociología, economía, ciencias del comportamiento, lógica, ética, psicología, religión, teoría de las organizaciones, antropología, comunicación, ciencias políticas y, más recientemente -y de nuestro particular interés-, las ciencias de la información; entre ellas, la informática, la bibliotecología y la archivística. Cada una de ellas presenta enfoques muy particulares que conforman su visión y, por tanto, su definición del término. Si bien hay elementos comunes entre todas ellas, esta misma multidisciplinariedad hace imposible llegar a una única definición que las contenga a todas, es un término polisémico y hay que estudiarlo como tal. En palabras de Harrison White (1985: 188), "Confianza es un término que por sí mismo es todo un racimo de definiciones".

El diccionario de la Real Academia de la Lengua Española consigna siete definiciones para la palabra 'confianza', más otras tres adicionales para 'de confianza'. En inglés, el Oxford English Dictionary consigna dieciséis definiciones sólo para la palabra 'trust', y el Merriam-Webster consigna nueve.

Adicionalmente, la falta de consenso incrementa la confusión de los lectores en lengua castellana en la traducción de palabras de otras lenguas, principalmente del inglés. Por ejemplo, las palabras trust y confidence, ambas traducidas con mucha frecuencia al español como confianza, tienen en inglés significados parecidos y relacionados pero diferentes: en inglés no son sinónimos; al traducir ambas como 'confianza', se convierten incorrectamente en sinónimos en español. 
Trust puede ser traducida como 'confianza', pero si confidence es algo distinto a trust, la traducción no puede ser también 'confianza'. Lo mismo sucede con trustworthiness y reliability, las cuales no son sinónimos en inglés - tienen diferencias sutiles - pero con frecuencia son traducidas al español como 'confiabilidad'. La palabra más aproximada para confidence es 'certeza'; se aclara: más aproximado, ya que no hay una idéntica. El punto es que no pueden ser iguales en castellano para no crear confusión. Desde mi punto de vista, el equivalente más aproximado en español para trustworthiness es 'solvencia', “carácter de ser fidedigno, carácter de ser fehaciente, formalidad, integridad, credibilidad". Si existieran las palabras en español, lo más aproximado sería fidedignidad* o fehaciencia*; desgraciadamente no existen. El equivalente de reliability sí es 'fiabilidad' o 'confiabilidad'. Como puede verse, la ambigüedad de las traducciones al español también abona a la confusión acerca del término. Los anteriores son sólo algunos ejemplos al respecto, existen muchos más de ellos.

Confianza es un término que ha sido analizado y definido desde hace casi tres milenios y que ha evolucionado; al respecto, Silver (1985), Misztal (1966) y Seligman (1997) han hecho recuentos extensivos de estudios y definiciones históricas del concepto. Existen además numerosas investigaciones que presentan diversas tipologías de análisis y construcciones de confianza; se han sugerido tipologías de los objetos de la confianza, como la de McKnight y Chervany (2002); de los modos en que se manifiesta, como la de Zucker (1986); de los procesos involucrados, en el caso de Lewicki y Bunker (1995), y del contenido, como la tipología de McAllister (1995) entre otros.

Barbalet (2009) estableció que la confianza se ha definido de diversas maneras en términos de: 
1. Los beneficios que proporciona (cooperación, cohesión política, fiabilidad, orden social, etc.).

2. La disposición de los que dan la confianza (afectiva, calculativa, moral, pragmática, etc.).

3. El carácter de la relación entre el confiante y el confidente (contractual, dependiente, de explotación, de reciprocidad, etc.). Con frecuencia se define con adjetivos: la confianza puede ser básica, cognitiva, emocional, personal, grupal, interpersonal, mutua, social, colectiva, institucional, sistémica, unilateral, organizacional, etcétera.

Además, el concepto de confianza varía sustancialmente en función de época y lugar geográfico.

McKnight y Chervany (1996) realizaron un exhaustivo estudio donde analizaron más de sesenta textos acerca de la confianza provenientes de diferentes campos: administración, comunicación, sociología, ciencia política, psicología y economía, y agruparon los significados en categorías de tratamiento del término. De acuerdo con sus resultados, la confianza fue tratada en esos documentos desde puntos de vista estructural (6\%), disposicional (4\%), como actitud (3\%), como sentimiento (17\%), como expectativa (20\%), como creencia (24\%), como intención ( $8 \%$ ) y como estado cognitivo (18\%). Además, establecieron y cuantificaron diecisiete tipos de atributos relacionados con las diversas conceptualizaciones acerca de la confianza.

Cabe subrayar que aunado a los estudios acerca de la confianza existen numerosos conceptos asociados que se entrelazan con el primero y hacen todavía más complejo su estudio y caracterización: riesgo, desconfianza, credibilidad, solvencia, etcétera. Por su brevedad, en este documento no es el caso hacer un análisis ni de las definiciones y caracterizaciones de la confianza, ni de los términos asociados desde todos los enfoques disciplinarios o metodológicos mencionados. El punto ha sido resaltar que por su 
multidisciplinariedad es imposible llegar a una única definición del concepto que contenga a todas las disciplinas: es un término polisémico y hay que estudiarlo con mucho más detalle. Además, dentro de cada campo de estudio hay diferentes subcampos, visiones, teorías, enfoques, etcétera, que lo caracterizan y definen. No hay tampoco una visión simple dentro de cada disciplina.

Para ilustrar esto, y tomando como ejemplo el punto de vista de la sociología, podemos mencionar algunos de sus diversos enfoques: James Coleman (1990) introdujo el análisis de la confianza como parte del capital social: el componente de capital humano que permite a los miembros de una cierta sociedad confiar entre ellos y cooperar en la formación de nuevos grupos y asociaciones. El término fue introducido por primera vez en los años setenta para contraargumentar la idea de que la sociedad no es más que un agregado de individuos y acciones independientes; el concepto implica además ciertos recursos adicionales implícitos en los procesos sociales a los que las personas pueden recurrir para facilitar sus acciones. Este capital social, a diferencia del capital físico y el humano, está embebido en las relaciones interpersonales, ya que los individuos no actúan de forma independiente unos de otros, sino que desarollan confianza a través de interacciones mutuas continuas. Dicho de otra forma, estos patrones forman las organizaciones sociales y las interacciones determinan el capital social. Para Coleman, el grado de confiabilidad de las organizaciones sociales es la forma más importante de capital social.

Fukuyama (1995) notó que el concepto de capital social, muy utilizado entre los economistas, se está desarrollando con mayor frecuencia bajo la premisa de que el capital está cada vez menos representado por el dinero, la tierra, las fábricas y las máquinas, y cada vez más por el conocimiento y las habilidades de las personas. A partir de estos autores, otros nuevos 
han incursionado en el tratamiento de la confianza como una parte muy importante del capital social. Barber (1983: 164165) establece que la confianza "es la expectativa de persistencia y cumplimiento del orden natural y social".

Luhmann (1996), uno de los mayores teóricos del tema bajo el enfoque sociológico, consideró la confianza como un factor de enorme importancia en la sociedad contemporánea:

La gran complejidad del orden social crea una necesidad más grande de coordinación que se satisface cada vez menos por medio de la familiaridad. [...] En estas circunstancias, la confianza y la familiaridad tienen que buscar una nueva relación, que sea recíprocamente estabilizadora, la cual ya no se basa en un mundo inmediatamente experimentado, asegurado por la tradición, los supuestos, los mitos o la religión.

\section{Resumiendo a Luhmann,}

Laconfianza reducelacomplejidad socialen la medidaquesuperalainformación disponibleygeneraliza las expectativas de conocimiento, al reemplazar la información insuficiente que se tiene por una seguridad internamente garantizada [...] La confianza no es la única razón del mundo, pero no podría establecerse una concepción muy compleja y estructurada del mundo sin una sociedad definitivamente compleja, que a la vez no podría establecerse sin la confianza [...] la confianza es indispensable al propósito de aumentar el potencial de un sistema social para la acción más allá de las formas elementales.

\section{Piotr Sztompka (1999: 71) comenta al respecto:}

La importancia de la confianza se deriva de ciertas cualidades fundamentales de la acción humana. Al interactuar con los demás debemos articular constantemente expectativas sobre sus acciones 
futuras. Con frecuencia carecemos de la posibilidad de predicción precisa y exacta o control eficiente. Frente a esas personas quedamos en un estado de incertidumbre, desconcierto y sorpresa. Empero, a menudo no podemos abstenernos de actuar - ya sea para satisfacer nuestras necesidades o para hacer realidad nuestros objetivos- - Tenemos necesidad entonces de enfrentar el riesgo de que esas personas pudiesen volverse contra nosotros [...] en suma: la confianza es una apuesta sobre las futuras y eventuales acciones de otros.

Stompka (1999) organiza además los "objetos primarios de la confianza" en cinco categorías:

1. Confianza en los íntimos y allegados; esto es, las personas que nos son cercanos: familiares, amigos, colegas, vecinos, socios, etcétera. 2. Confianza en los roles sociales; las personas que por su papel social nos son confiables a priori: el médico, el maestro, el sacerdote, el juez, el notario, el ombudsman.

3. Confianza en las instituciones; la escuela, la universidad, la iglesia, la banca, la bolsa, el periódico, el hospital, la biblioteca o el archivo y, a su vez, en los procesos institucionales, elecciones, representación popular, parlamentos, etcétera.

4. Confianza en los sistemas expertos o abstractos; telecomunicaciones, tráfico aéreo, energía, agua, transportes, redes de cómputo, etcétera.

5. Confianza en los sistemas sociales; es decir, el orden social, la administración pública, el sistema de salud, la democracia, los medios de comunicación, etcétera.

Como puede verse, se han tratado de hacer múltiples tipologías y métodos de comparación y organización del término. Para este tema, son particularmente interesantes las divisiones de estudios de la confianza de Sitkin y Roth (1993) en cuatro categorías: 1) Confianza como un atributo del individuo, 
2) confianza como un comportamiento, 3) confianza como una característica situacional, 4) confianza como un acuerdo institucional. Y también la de Hosmer (1995), quien agrupa los estudios acerca de la confianza en 1) expectativas individuales, 2) relaciones interpersonales, 3) estructuras sociales, 4) intercambios económicos y 5) principios éticos.

Como ha podido verse, no es posible hablar de confianza en términos generales, es necesario plantearla en términos de quién la otorga y la recibe, si es personal, institucional, corporativa, social, etc., y contextualizarla dentro de un enfoque disciplinario: psicológico, filosófico, sociológico, político, económico, informático, etcétera. Esta contextualización es necesaria también dentro de las disciplinas que nos son más cercanas: la bibliotecología, la archivística y la informática. En bibliotecología, puede estudiarse este concepto diversificadamente para libros, revistas, diarios, bancos de datos, repositorios, etcétera. En la archivística, puede estudiarse para documentos de archivos gubernamentales, privados, históricos, científicos, artísticos, entre otros. En la informática, puede estudiarse para sitios web, aplicaciones y programas, blogs, etcétera. Bajo una óptica general que involucre las tres disciplinas, y para ilustrar lo anteriormente dicho, podemos centrarnos en este momento sólo en el enfoque personal y hacia la información que se encuentra en los sitios web.

En el campo de la preservación documental digital de archivos, se han estudiado a fondo en años recientes las técnicas para preservar un documento digital a lo largo de generaciones tecnológicas a pesar de los cambios impuestos por su obsolescencia. Igualmente importante ha sido estudiar y establecer las características y los atributos que al preservarse permiten inferir que un documento digital sigue siendo auténtico, exacto, íntegro, veraz; esto es, confiable. Entre los principales hallazgos, se encuentra el hecho de que además 
de contar con esos atributos, la confianza en la información se ha ido trasladando de ésta en sí, a su custodio (Duranti, 2005). De forma semejante, en el mundo de los medios electrónicos la confianza en la información se da en función de que cuente con ciertos atributos, pero además, esa confianza se ha ido trasladando cada vez más desde la información en sí a su productor. Es decir, la confianza en la información también se evalúa y se otorga cada vez más en función de la persona, organización, sitio o medio que la produce.

La información que se encuentra en la web se piensa generalmente como un todo informacional, pero en realidad esa información dentro de la red está segmentada en múltiples sectores que tienen diferentes propósitos y siguen entre ellos reglas distintas de producción, distribución y uso, y por ende, los factores que inciden en la confianza en esa información varían en función del sector del que se trate. Más allá de algunas consideraciones básicas y superficiales, no es posible ni conveniente generalizar acerca de la confianza que los usuarios tienen en la información proveniente de la red, pues ésta es afectada por factores del sector de la web al que pertenece la información, su calidad intrínseca, las características personales del usuario que varían en función de edad, ubicación geográfica, experiencia, sector socioeconómico, etcétera. En términos generales, a esta compleja interrelación de información, personas y organizaciones se le conoce genéricamente como e-trust, e-confianza o confianza en los ambientes digitales (Taddeo, 2009).

Sztompka (1999) estableció que en cuanto a la confianza como una relación con los demás, su otorgamiento se basa en una estimación de la "solvencia" o "medida de la fiabilidad" -trustworthiness - de la contraparte. Estas estimaciones pueden tener varios niveles. El primero de ellos es la "solvencia primaria" del confidente; es decir, la percepción del 
confiante en la reputación, el desempeño y la apariencia del confidente. La probabilidad de confianza bien fundada aumenta con la cantidad y variedad de información verdadera sobre el confidente.

De acuerdo con esta teoría, el primer elemento para valorar la posible solvencia de un eventual confidente es su reputación. "Reputación es simplemente un recuento de conductas pasadas para crear con ello expectativas de conductas futuras" (ídem.). Por lo general, las personas u organizaciones sujetas a confianza ya han estado ahí por cierto tiempo. "En los casos de intercambio de confianza entre instancias, rara vez se encuentra una situación de nula existencia de historia en ellas" (Good, 1990). La reputación se va conformando por experiencias pasadas, positivas o negativas, historias o relatos, testimonios, evaluaciones, certificaciones, antigüedad, premios y reconocimientos, etcétera.

El segundo elemento para valorar la posible solvencia de un eventual confidente es su desempeño. La reputación tiene que ver con la fama y conducta pasada del objeto de confianza y pretende establecer si su actuación ha sido típica, continua, acumulada.

El desempeño se relaciona con la conducta, las acciones y los resultados presentes del confidente, lo cual se compara con la conducta requerida para cumplir con sus responsabilidades cotidianas, especificadas por el confiante. Pretende evaluar el estado actual del eventual confidente para a partir de ahí hacer una extrapolación con miras a esperar o no una cierta conducta del mismo en el futuro (Sztompka, 1999).

El tercer elemento para valorar la posible solvencia de un eventual confidente, de acuerdo con Sztompka, es su apariencia: el conjunto de características o circunstancias con las que una persona u organización se presenta o es 
percibida, con miras a indicar su solvencia, fama, rango, poder o capacidad. En relación con la confianza, la apariencia tiene que ver con factores psicológicos que el confiante interpreta como valores de personalidad, identidad y estatus. Estos factores son muy numerosos y, como en la reputación, varían dependiendo de la cultura y la época, de persona a persona, y son por tanto subjetivos.

Como ya se estableció, la confianza en el entorno digital está segmentada en múltiples sectores que tienen diferentes propósitos y siguen reglas distintas de producción, distribución y uso y, por consecuencia, los factores que inciden en la confianza en esa información varían en función del sector que la use. Por esto, es necesario desglosar y estudiar los elementos de confianza por cada sector y tipo de material que se encuentra en la red. Esto es algo muy extenso y excede con mucho los alcances y límites de este documento. A guisa de ejemplo, se puede tomar la información existente en sitios web. Muchos autores han reflexionado acerca del hecho de que, con la excepción del comercio electrónico, en la ciencia de la información se ha prestado poca atención a las cuestiones de la relación información-confianza, así como de los motivos para que las personas confíen en un sitio web.

Por lo general, el primer criterio para calificar sitios web consiste en la ponderación que hacen los mecanismos de búsqueda y la recuperación de la información publicada, los cuales en la inmensa mayoría parten del uso de buscadores convencionales de la red. Todos los buscadores de este tipo tienen algoritmos muy semejantes que buscan y asocian palabras para encontrar, ordenar y presentar los resultados al usuario.

Como hemos observado, el enorme número de páginas web existentes, combinado con la búsqueda por palabras o frases, arroja una inmensa cantidad de resultados. El orden 
en que se presentan las páginas al usuario no es aleatorio: está ponderado por los buscadores principalmente en función de cuáles de los sitios resultados tienen más visitas o más referencias hacia ellos. En muchos casos, esto introduce más irrelevancia en lugar de resolverla. La mayoría de los buscadores ponderan el orden de presentación basados en un principio denominado "la sabiduría de las masas", el cual establece que en lugar de que un experto de una organización califique la autoridad de un cierto sitio de manera arbitraria, se deja al conglomerado de la red hacerlo, ya que el consenso de un grupo de personas en la red puede hacer un análisis más exacto y por tanto mejor de una información, comparado con el que un especialista pudiese hacer. En consecuencia, los sitios con más visitas y más hipervínculos deben ser más autorizados que los que tienen menos. Los algoritmos de la mayoría de los buscadores web usan este principio como factor principal y cuentan las visitas y los vínculos para acomodar el orden de presentación de sus resultados. Esto sin contar los ordenamientos derivados de publicidad pagada.

Naturalmente este principio ha sido altamente cuestionado debido a que, como ciertos expertos ya han demostrado (Gladwell, 2002), la "sabiduría de las masas" por lo general es influida por ciertos líderes o personas con autoridad moral, tengan o no la razón, sepan o no del tema. Además, la web ha introducido el fenómeno de la "retransmisión" o "repetición" de información que se vuelve tendencia o moda, independientemente de su importancia, validez y veracidad. Más allá de la ponderación de los buscadores, numerosos autores se han dedicado a estudiar las bases de la credibilidad y confianza de los sitios web. Entre los más relevantes, podemos mencionar los siguientes autores y estudios al respecto: 
Jim Kapoun (1998) sentó las bases de las características sensibles de calidad de las páginas web que debían ser evaluadas. En términos generales, estableció cinco puntos fundamentales a evaluar:

- Exactitud, la cual tiene que ver con la concordancia del tipo de sitio web y su contenido.

- Autoridad, que es proporcional a la calidad y seriedad de los autores y editores.

- Objetividad, que está relacionada con la intención y el rigor de la información de la página.

- Actualidad, que tiene relación con la vigencia y actualidad de los contenidos.

- Cobertura, la cual se relaciona con el número de datos o unidades de información que contiene.

A partir de esta lista, otros autores han ido refinando los elementos a revisar: B. J. Fogg (2002), de la Universidad de Stanford, ha realizado numerosos estudios acerca del comportamiento de usuarios y su relación con la aceptación de sitios web. A partir de esos estudios, concluye que la credibilidad de un sitio web es directamente proporcional a su apariencia de fiable y profesional, y la divide en cuatro tipos:

1. Credibilidad presunta, la que tiene el sitio por supuestos previos generales: prestigio, marcas de renombre, logos o firmas, etcétera.

2. Credibilidad por reputación, la que tiene el sitio por referencias de terceros, recomendaciones, reseñas, experiencias, fuentes, citas, etcétera.

3. Credibilidad aparente, la que el sitio logra a partir de su diseño, imagen, usabilidad, amigabilidad, limpieza de texto, etcétera.

4. Credibilidad ganada, la que el sitio logra en función de las experiencias de los usuarios, servicio a clientes, seriedad en las operaciones, etc. 
Este autor extrae como resumen diez factores determinantes por los que las personas confían en sitios web; en orden de importancia, éstos son:

- El sitio presenta facilidades para verificar los contenidos existentes en él.

- El sitio parece tener una buena organización tras él.

- Se hacen evidentes la experiencia y el conocimiento del sitio a través de contenidos y/o servicios sólidos.

- El sitio hace patente que está conformado y atendido por personas serias, honestas y fiables.

- El sitio permite establecer contacto con él fácilmente.

- El diseño del sitio parece profesional o apropiado a sus propósitos.

- El sitio es fácil de navegar y útil.

- El sitio es actualizado con frecuencia, o al menos hace notar que ha sido revisado recientemente.

- El sitio usa anuncios, avisos, etc. con moderación.

- El sitio no tiene errores de redacción u ortografía.

Lisa Barone (2010) presenta una lista en forma inversa; es decir, once causas de desconfianza en un sitio web. En términos generales, se observa una congruencia con lo consignado en la mayoría de los artículos al respecto:

- Está redactado como un folleto.

- Tiene errores de ortografía o de redacción.

- No explica en qué es diferente a otros sitios semejantes.

- Tiene demasiada información.

- No ha sido actualizado en mucho tiempo.

- Es difícil de navegar.

- Está lleno de palabras técnicas de moda o grandilocuentes.

- Parece una plantilla preestablecida.

- No hay página de "acerca de" o "quiénes somos". 
- No tiene una dirección postal o física.

- No tiene citas, referencias, fuentes, etc., de terceros.

En resumen, los autores y tutoriales consignan como elementos fundamentales para establecer la calidad de un medio o sitio:

1. Información propia del URL. ¿Qué tipo de sitio es?: personal, institucional, corporativa, gubernamental, etc. Cuál es el tipo de dominio: org, edu, com, gov, país, etcétera.

2. Información acerca del o los editores en apartados como "About us", "Philosophy", "Background", "Who am I", etcétera.

3. ¿Cuál es la intención del sitio?: informar, dar hechos, dar datos, explicar, persuadir, enseñar, vender, publicitar, compartir, promover, negar, atacar.

4. Facilidad de identificar a los autores de los textos o información; no anonimidad; cualificaciones de los autores. Qué tan conocidos o reconocidos son.

5. Vigencia y actualidad; fecha de inicio del sitio web; fecha de publicación de la página; fecha de la última actualización; vigencia de la información; número de hipervínculos rotos.

6. Indicadores extras de calidad tales como vínculos, sitios adicionales, bibliografía, notas a pie de página; información complementaria; premios y reconocimientos de excelencia. ¿Qué tan buenos y reales son? 7. Referencias externas al sitio: ¿La página está indizada por sitios nacionales o internacionales recolectores de información? ¿Cuántos y de qué nivel?

8. Originalidad. ¿La información del sitio es original o reproducida? ¿Proviene de un índice o selección?

9. Alcance. ¿Cuántos documentos, datos o unidades de información contiene el sitio web?

El problema de la confianza en los medios, en especial en sitios web, existe y se está estudiando prácticamente desde que la 
red fue creada. Dado el inmenso número de sitios, su inusitada tasa de crecimiento y la falta de control de calidad, es inevitable que existan innumerables sitios que son insulsos, irrelevantes, superficiales, con información deleznable, sesgada o definitivamente falsa, o incluso nocivos y dañinos desde el punto de vista de la seguridad informática. Todo ello ha ido creando una serie de teorías, estudios, guías, metodologías y demás, destinadas a evaluar y calificar sitios web y su información con el propósito de ayudar a sus potenciales usuarios en el proceso de establecer o no una eventual confianza y credibilidad en ellos. Incluso podemos ya encontrar y diferenciar entre técnicas especializadas para evaluar un cierto sector o tipo de información: noticias, comercio, ciencia, etcétera.

James Herring (2011) ha subrayado a lo largo de diversos estudios que el principal aspecto de la enseñanza de habilidades de búsqueda de información a los estudiantes no consiste en cómo hallarla, sino en enseñarles cómo evaluar la información que han encontrado. Él agrega que la alfabetización informacional ya es considerada por los gobiernos de todo el mundo como una habilidad fundamental para la educación y la vida, y que las escuelas tienen un papel clave en el desarrollo de la alfabetización informativa de sus estudiantes. Carl Sagan expresó algo semejante: "saber muchas cosas no es lo mismo que ser inteligente. La inteligencia no es solamente información, sino también juicio, la manera en que se coordina y maneja esa información” (1982: 270).

Gil y Artz (2007: 18) también comentaron algo al respecto:

[...] la valoración para confiar o no en cualquier información o contenido proporcionado por una fuente electrónica es un proceso complejo afectado por muchos factores. La identificación y correlación de los factores que influyen en cómo se toman las 
decisiones de confianza en las tareas de recuperación de información, su integración y análisis, se convierte así en una capacidad crítica en un mundo de fuentes abiertas como la web.

Si se analizan los diversos estudios acerca de la confianza en relación con las fuentes de información en la web, se encuentran elementos muy interesantes. A manera de ejemplo, en el sitio del Global ccs Institute, que se dedica a este tipo de estudios, se consigna que de acuerdo con su origen, la información es confiable, de manera decreciente, al provenir de:

1) Institutos de investigación.

2) Artículos académicos.

3) Familiares y amigos.

4) Libros.

5) Noticias televisivas.

6) Sitios de Internet y blogs.

7) Diarios.

8) Comunicados gubernamentales.

9) Organizaciones ambientales.

10) Radio.

11) Administraciones locales.

12) Comunicados de grupos de interés.

13) Revistas.

14) Industria.

15) Redes sociales.

En la red pueden hallarse muchos estudios semejantes de variada índole que ilustran sobre los elementos de confianza en estos medios.

Lo anterior ha sido sólo un esbozo del estudio de los elementos de la confianza para un espectro muy particular, me he enfocado aquí en unas pocas disciplinas y sólo en la información 
de sitios web. El punto central es que, como ha podido constatarse, existe un campo de acción muy extenso, así como numerosos aspectos que explorar acerca del concepto confianza en la información. Esto puede y debe hacerse bajo muchos enfoques disciplinarios y metodológicos para personas, organizaciones y sistemas, y también para muchos subconceptos: libros, revistas, diarios, blogs, redes sociales, bancos de datos, archivos gubernamentales, archivos privados, repositorios artísticos y científicos, programas y aplicaciones, etcétera. Ello abre un inmenso campo de investigación y estudio, en particular a las disciplinas más cercanas a las ciencias de la información que son de nuestro particular interés: la bibliotecología, la archivística y la informática.

De todo lo anterior, pueden establecerse las siguientes conclusiones:

- Debido al auge de la información y las publicaciones en la red, es cada vez más difícil identificar la calidad de las fuentes, los medios y la información. Cada vez más personas se cuestionan hasta qué punto pueden confiar en la información a la que acceden; por lo mismo, en la medida en que la producción y el consumo de la información incrementa, crecen también los problemas de "confianza" o "desconfianza" en esa información.

- Como ha podido verse, el concepto de confianza no es nada simple, es multidisciplinario. Es por tanto un término polisémico, y debe ser contextualizado y enfocado siempre para poder abordarlo, crearlo y explicarlo, en especial en lo relativo a la confianza en la información. - Los factores de la confianza son múltiples y cuentan con variadas dimensiones: la confianza puede ser básica, cognitiva, emocional, personal, grupal, interpersonal, mutua, social, colectiva, institucional, sistémica, unilateral, organizacional, etcétera.

- Las ciencias de la información tienen un papel muy relevante en estudiar, explicar, crear, interpretar y enseñar la confianza en 
fuentes, medios e información. Esto abre un inmenso campo de investigación y estudio en estas disciplinas.

- Al margen de la técnica o metodología utilizada por cada usuario para evaluar y calificar la información proveniente de la web, se puede concluir que ésta es una habilidad que se vuelve parte indispensable y fundamental de la alfabetización informática de las personas.

- Dado que ésta es una habilidad que no es nata de las personas, esto es, se enseña y se aprende, abre una ventana de oportunidad profesional para los bibliotecarios y archivistas profesionales.

- Los medios y soportes tienen mucho que ver con los factores de confianza en la información por parte de los usuarios. El fenómeno de la confianza en medios y/o sitios web tiene sus elementos y características particulares y debe ser contextualizado y enfocado siempre para poder abordarlo y explicarlo.

- Lo mismo ocurre con otros tipos de materiales documentales (libros, revistas, diarios, mapas, catálogos, música, etcétera), que también tienen características particulares y deben ser contextualizados para su estudio.

\section{BIBLIOGRAFÍA}

(Todas las referencias electrónicas han sido verificadas como exactas y existentes al 30 de noviembre del 2016).

Barbalet, Jack (2009). "A Characterization of Trust and its Consequences". Theorie and Society, 38 (4), 367-382.

Barber, B. ( 1983). The Logic and Limits of Trust. New Brunswick: Rutgers University Press.

Barone, Lisa (2010). “11 Reasons Customers Don't Trust Your Web Site”. Small Business Trends. Entrada del 6 de julio de 2010. 
Disponible en: http://smallbiztrends.com/2010/07/11-reasonscustomers-don't-trust-your-web-site.html.

Coleman, J.C. (1990). Foundations of Social Theory. Cambridge: Harvard University Press.

Duranti, L. (2005). La conservación a largo plazo de documentos electrónicos auténticos: Hallazgos del Proyecto InterPARES. Cartagena: Ayuntamiento de Cartagena.

Fogg, B.J. (2002). "Stanford Guidelines for Web Credibility." A Research Summary from the Stanford Persuasive Technology Lab. Stanford: Universidad de Stanford. Disponible en: https://credibility.stanford.edu/guidelines/.

Fukuyama, F. (1995). Trust: The Social Virtues and the Creation of Prosperity. Nueva York: Free Press.

Ganz, J.F. y D. Reinsel (2012). “The Digital Universe in 2020”. IDC (International Data Corporation). EMC Corporation. Disponible en: http://www.emc.com/collateral/analyst-reports/idc-the-digital-universe-in-2020.pdf.

Gil, Y. y D. Artz (2007). "Towards Content Trust of Web Resources". Journal of Web Semantics, 5 (4), 227-239. Disponible en: http://www.isi.edu/ gil/papers/gil-artz-jws07.pdf.

Gladwell, M. (2002). The Tipping Point. Nueva York: Back Bay Books.

Global ccs Institute. Sitio web disponible en: https://hub.globalccsinstitute.com/publications/public-perceptions-low-carbon-energy-technologies-results-dutch-large-group-workshop/71.

Good, D. (1990). "Individuals, Interpersonal Relations, and Trust". En D. Gambetta (ed.). Trust: Making and Breaking Cooperative Relations. Oxford: Blackwell Pub.

Herring, James E. (2011). "From School to Work and from Work to School: Information Environments and Transferring Information Literacy Practices". Information Research, 16, (2). Disponible en: http://www.informationr.net/ir/16-2/paper473.html. 
Hosmer, L.T. (1975). "Trust: The Connecting Link Between Organizational and Philosophical Ethics". Academy of Management Review, 20 (2), 379-403. Disponible en: http://jstor.org/stable/258851.

Kapoun, J. (1998). "Teaching Undergrads WEB Evaluation: A Guide for Library Instruction”. CERL News (julio/agosto, 522-523.

Lewicki, R.. J. y B. Bunker (1995). "Trust in Relationships: A Model of Development and Decline”. En Rubin Bunker et al. (eds.). Conflict, cooperation and justice (133-173). San Francisco: Jossey-Bass. Disponible en: http://www.researchgate.net/publication/232534885_Trust_in_relationships_A_model_of_development_and_decline.

Kennedy, J.F. (1962). Discurso pronunciado en la Universidad de Yale el 11 de junio de 1962. Disponible en: http://millercenter. org/president/speeches/speech-3370.

Luhmann, Niklas (1996) [1968]. Confianza. Barcelona: Anthropos.

McAllister, D.J. (1995). "Affect and Cognition Based Trust as Foundations for Interpersonal Cooperation in Organizations". Academy of Management Journal, 38 (1), 24-59.

McKnight, H. y N. Chervany (2002). "What Trust Means in ECommerce Customer Relationships: An Interdisciplinary Conceptual Typology". International Journal of Electronic Commerce, 6 (2), 33-57.

(1996). The Meanings of Trust. Minnesota: University of Minnesota Research Center Working Papers Series. Disponible en: http://misrc.umn.edu/wpaper/WorkingPapers/9604.pdf.

Misztal, B.A. (1996). Trust in Modern Societies. Cambridge: Polity Press.

Sagan, C. (1982). "La persistencia de la memoria". Cosmos. (270). Barcelona: Planeta.

Seligman, A.B. (1997). The Problem of Trust. Princeton, Princeton University Press. 
Silver, A. (1985). "Trust in Social and Political Theory". En G.D. Suttles y M.N. Zald (ed.). The Challenge of Social Control (52-67). Nueva Jersey: Ablex.

Sitkin, S.B. y N. L. Roth. (1993). "Explaining the Limited Effectiveness of Legalistic 'Remedies' for Trust/Distrust". Organization Science, 4, 367_392.

Sztompka, Piotr (1999). Trust: A Sociological Theory. Cambridge: Cambridge University Press.

Taddeo, Mariarosaria (2009). "Defining Trust and E-Trust: From Old Theories to New Problems". En A. Mesquita y Chia-Wen Tsai (eds.). International Journal of Technology and Human Interaction, 5 (2).

White, Harrison (1985). "Agency as Control". En J.W. Pratt y R.J. Zeckhauser (eds.).Principals and Agents: The Structure of Business. (187-212) Boston: Harvard Business School Press.

Worldometers. Sitio web disponible en: http://www.worldometers. info.

Zucker, Lynne G. (1986). "Production of Trust: Institutional Source of Economic Structure, 1840-1920". Research in Organizational Behavior, 8, 53-111. 


\title{
La importancia de preservar el patrimonio videográfico en los archivos de televisión
}

\author{
Ubaldo P. Candia Reyna \\ Videoteca del Canal de Televisión \\ UASLP
}

\section{INTRODUCCIÓN}

$\mathbf{L}$

a sociedad de la información está evolucionando a un ritmo considerable. De acuerdo con Documanía (2013), en un estudio publicado en la revista Science en el año 2011, se pretendía cuantificar la información generada en el mundo. Ese año, el cEo de Google, Eric Schmidt, afirmó que la humanidad había creado hasta 2003 una cantidad equivalente a 5 exabytes, y añadió que para el año del artículo esa cifra se generaba en dos días Ese mismo estudio refiere que "la tecnología digital domina claramente a la analógica".

La página Worldometers comparte diariamente las estadísticas mundiales en tiempo real sobre sociedad y medios, entre otras áreas. Ahí se señala que la cantidad de usuarios de Internet en el mundo ha crecido exponencialmente en los últimos años. A su vez, la empresa Domo recoge una infografía en donde se aprecian las magnitudes en cuanto al tráfico de información en el mundo. Una parte considerable de este tráfico se presenta en el formato de video. 


\begin{tabular}{|l|l|}
\hline \multicolumn{2}{|c|}{ Decimal } \\
\hline 1 byte (B) & 8 bits \\
\hline 1 kilobyte (KB) & $1000 \mathrm{~B}$ \\
\hline 1 megabyte $(\mathrm{MB})$ & $1000 \mathrm{~KB}$ \\
\hline 1 gigabyte $(\mathrm{GB})$ & $1000 \mathrm{MB}$ \\
\hline 1 terabyte $(\mathrm{TB})$ & $1000 \mathrm{~GB}$ \\
\hline 1 petabyte $(\mathrm{PB})$ & $1000 \mathrm{~TB}$ \\
\hline 1 exabyte $(\mathrm{EB})$ & $1000 \mathrm{~PB}$ \\
\hline 1 zettabyte $(\mathrm{ZB})$ & $1000 \mathrm{~EB}$ \\
\hline 1 yottabyte $(\mathrm{YB})$ & $1000 \mathrm{ZB}$ \\
\hline
\end{tabular}

Imagen de Documanía 2.0 (2013).

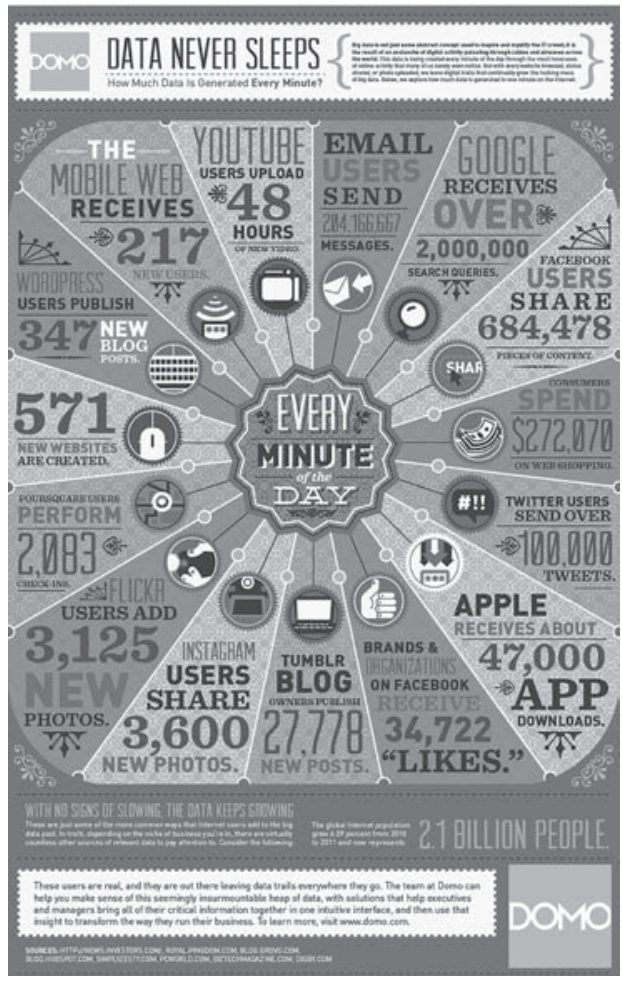

Imagen de Domo (2012). 
Los archivos de televisión están en constante transformación en todo el mundo; día a día se generan grandes cantidades de imágenes en movimiento. Desde que en 1936 la BBC emitió la primera transmisión publica regular en el mundo, se ha vuelto un gran reto en los archivos garantizar el acceso permanente con una mínima pérdida de calidad a los contenidos.

E. Martínez Odriozola (1992) expresa que el hecho de no sólo poder estar presente en los grandes acontecimientos de la historia, sino de permitir su conservación a lo largo del tiempo, hacen de la televisión y del material audiovisual de televisión una fuente de inestimable valor para la sociedad.

El lenguaje videográfico en la actualidad juega un papel fundamental en la enseñanza-aprendizaje; podría decirse que se ha vuelto bidireccional dado que, a diferencia del papel que tenía el consumidor final de ser sólo un espectador que recibía los contenidos, el consumidor de ahora toma un rol de creador, editor y distribuidor de material digital.

La Era digital ha marcado un cambio en el consumo de la información y en la manera de documentar, el video se ha convertido en uno de los formatos estrella de la comunicación y esto exige al profesional de la información preservar de manera responsable lo que se genera en este formato y constituir una memoria y patrimonio audiovisual.

En cuanto a la gestión del patrimonio audiovisual en medios de comunicación, el autor Marcos Recio señala: "El nivel de democracia de una sociedad se mide también por la calidad y gestión de sus archivos, y por el acceso de los ciudadanos a los documentos que estos conservan y a la información que contienen; la comunicación, la información y el saber son pilares importantes en el desarrollo sostenible" (2013: 79). El acceso del patrimonio audiovisual de cada país a la memoria del mundo debe de estar garantizado. 
Patrimonio Audiovisual

La Unesco (1980) ha recomendado la salvaguarda y conservación de las imágenes en movimiento, reconoce oficialmente las películas, la televisión y las grabaciones sonoras, y recomienda considerarlas parte del patrimonio cultural así como la información escrita lo ha sido durante siglos.

Con la proclamación del día 27 de octubre en el año 2005 como Día mundial del patrimonio audiovisual, se determinó que los principales objetivos serían:

1. Fomentar la toma de consciencia de que es imprescindible preservar ese patrimonio.

2. Dar oportunidades para reseñar aspectos locales, nacionales e internacionales específicos de ese patrimonio.

3. Poner de relieve la accesibilidad de los archivos.

4. Llamar la atención de los medios de comunicación sobre la problemática del patrimonio audiovisual.

5. Destacar el patrimonio audiovisual en peligro, especialmente en los países en desarrollo.

Los formatos audiovisuales son extremadamente vulnerables y se estima que no se cuenta con más de diez a quince años para transferirlos a un formato digital y así prevenir su pérdida. Según la Unesco (2005), gran parte del patrimonio audiovisual del mundo ya ha sido irrevocablemente perdido por abandono, destrucción, deterioro y por la falta de recursos, habilidades y estructuras, lo que ha empobrecido la memoria de la humanidad. Su objetivo es desarrollar una infraestructura de archivos audiovisuales, profesionales competentes y puntos de referencia profesionales reconocidos para garantizar la salvaguardia y preservación del patrimonio audiovisual de la humanidad.

Es importante considerar el mensaje de la directora general de la Unesco con motivo del Día mundial del patrimonio au- 
diovisual el 27 de octubre de 2015. Irina Bokova resaltó que es esencial que el patrimonio audiovisual sea accesible para todos. Sin embargo, los documentos audiovisuales son seres vivos y, por ende, también vulnerables y frágiles. La desaparición de este patrimonio nos impide también en ocasiones comprender en profundidad la historia de las sociedades y sus pueblos.

La Unesco creó el programa Memoria del Mundo en 1992. El impulso original de este programa es la consciencia creciente del lamentable estado de conservación del patrimonio y el deficiente acceso a éste en distintas partes del mundo. La guerra y los disturbios sociales, aunados a una grave falta de recursos, han empeorado problemas que existen desde hace siglos.

Otro programa importante a favor de la preservación es Save Your Archive, de la Federación Internacional de Archivos de Televisión (FIAT), presentado en la conferencia mundial de 2012 en Londres. Su propósito fundamental es promover la protección de los archivos audiovisuales vulnerables o en situación de riesgo al proporcionar un pequeño fondo para soportar uno o más proyectos. Cada año se ha centrado en la preservación, digitalización y valoración del contenido de los archivos. El apoyo también puede incluir asesoramiento profesional, el equipo, la formación y la financiación directa.El 10 de octubre de 2015, en Viena, se dieron a conocer los tres ganadores de la financiación y apoyo a su archivo de televisión: La Fundación Patrimonio Colombia, una organización privada de Italia y Televisión Croata HRTV.

Preservación Videográfica en los archivos de TELEVISIÓN

Del Valle Gastaminza (2011) refiere que algunas de las industrias cinematográficas y televisivas desprecian sus propios 
productos en cuanto dejaban de ser rentables. Pocas iniciativas públicas o privadas han asumido la defensa de ese patrimonio y muy pocas de ellas además surgieron de las grandes instituciones relacionadas con la archivística, la bibliotecología o la documentación.

Los archivos de las televisoras recopilan videos físicos o digitales de manera organizada. Esto se hace con el objetivo de mantener en buen estado toda clase de documentos videográficos en soportes como $16 \mathrm{~mm}$, pulgada, 3/4 Umatic, Betacam sp, Betacam Digital, DvcAM, HDCAM, Minidv o en DVD, servidores, discos duros (internos y externos) y LTO.

La decisión de preservar el material de televisión en México ha sido responsabilidad de las televisoras debido a la falta de una legislación en nuestro país sobre la preservación de material de este medio, salvo el depósito legal, que obliga a los editores y productores a contribuir a la integración del patrimonio cultural de la nación entregando ejemplares de sus obras a la Biblioteca Nacional y la Biblioteca del Congreso de la Unión. Los lineamientos sobre qué preservar y qué desechar se rigen por los fines de las televisoras, ya sean públicas o privadas, y obedecen a su capacidad de almacenamiento. La función de preservar e identificar el valor social, cultural e histórico también recae en la persona a quien pertenezcan los derechos morales o patrimoniales de una obra.

Tomar la responsabilidad de preservar y constituir un patrimonio es un asunto trascendental, se deben de considerar las consecuencias financieras, invertir en recursos y actuar con energía, con una visión clara de los objetivos a corto, mediano y largo plazo. Para la Unesco, la calidad de las decisiones dependerá del conocimiento seguro y probable de los objetos considerados, las tareas que serán necesarias, las expectativas de los interesados y los recursos de que se disponga. Para llevar a cabo tan importante labor, se requiere 
contar con personal calificado que conozca los procesos de diagnóstico, identificación, catalogación y clasificación, conservación, almacenamiento, y digitalización y acceso. Se tiene que tomar en cuenta que el acceso permanente es el objetivo de la preservación.

Diversos organismos internacionales coinciden que se deben de tomar en cuenta estos factores para elaborar planes de preservación:

1. El valor intrínseco y extrínseco del material.

2. La obsolescencia del soporte y el formato.

3. Las expectativas de vida del documento.

En estos tiempos, preservar material en formato digital no es una tarea nada fácil, considerando que el video digital ocupa mucho espacio de almacenamiento y esto genera grandes costos. Los programas de preservación requieren sistemas, software y tecnología de punta, así como personal capacitado para llevar acabo las funciones propias de esta tarea. En todo caso, según la Unesco deben preverse sistemas y herramientas que permitan:

- Almacenar y administrar el material de la colección.

- Almacenar y administrar los metadatos.

- Controlar la transferencia del material a la colección, incluida probablemente su recolección.

- Tratar la información relativa a los derechos y controlar el acceso en conformidad con dichos derechos.

- Almacenar y administrar las herramientas que permiten el acceso al material, como programas informáticos originales, programas complementarios y programas de conversión y emulación.

- Ofrecer a los usuarios la función de búsqueda.

- Realizar las copias necesarias para los usuarios. 
- Controlar muchos de los procesos descritos en las presentes directrices, especialmente los que generan información relativa a la gestión, copian material de un lugar o de un formato a otro, o requieren sistemas automáticos de verificación.

Una cuestión a resaltar es la responsabilidad que recae en el profesional de la información encargado de preservar un archivo videográfico; para Ray Edmonson (2004), esta persona se encarga de mantener la autenticidad y garantizar la integridad del material que se le ha confiado, y debe protegerlo de los daños materiales, la censura o la alteración deliberada. Su elección y accesibilidad en nombre del interés público han de regirse por normas objetivas y no por presiones políticas, económicas, sociológicas o ideológicas. Esta profesión no suele ser tan vistosa o sofisticada como las industrias cuya producción protege, carece de fondos adecuados, no es conocida y con frecuencia exige grandes dosis de tiempo y energía. Quienes se ven atraídos por ella y la ejercen son individuos motivados que consideran que el buen desempeño laboral es una recompensa personal.

\section{VIDEOTECA DE TV UASLP}

La Unesco ha señalado en las Directrices para la Preservación del Patrimonio Digital (2003) que entre las entidades de confianza para llevar a cabo las tareas de preservación están las universidades y demás instituciones de investigación y enseñanza, quienes tienen un interés natural en garantizar el acceso permanente a ciertos tipos de objetos digitales, y pueden ofrecer a la vez la viabilidad a largo plazo y la infraestructura técnica para desempeñar una función de preservación. 
En la División de Difusión Cultural de la Universidad Autónoma de San Luis Potosí, se encuentra la Coordinación de Televisión Universitaria. Desde 1988, esta coordinación concentró en una videoteca la memoria audiovisual de la universidad, el estado y algunas colecciones de otros estados del país. Este archivo audiovisual almacena formatos de video 3/4, Betacam, DvcAm, HDvcam, Minidv, DVD y digital, así como una pequeña cantidad fotográfica y de audio. En estas colecciones se encuentra plasmado el devenir histórico, cultural, científico y de diferentes ramas del conocimiento; por su tipo de contenidos y unicidad, estos audiovisuales son considerados un patrimonio, y se llevan diversas tareas a favor de la preservación de las mismos contenidos. Televisión Universitaria los difunde a través de diferentes espacios como la televisión abierta y de paga; desde la videoteca de televisión universitaria se ha contribuido a hacer accesibles estos contenidos a través del catálogo público de la Universidad y dos canales web en YouTube.

Internet se ha convertido en un instrumento de acceso a la información cada vez más eficaz, cuenta con una diversidad de herramientas y programas que otorgan grandes cantidades de contenidos. YouTube, que es un servicio gratuito de acceso compartido a videos en Internet, y cuyo abrumador éxito parece no tener límites, se ha convertido en el más grande, importante y principal canal de comunicación y promoción de videos, y en uno de los iconos de referencia de la web social. En el año de 2010, la videoteca de Televisión Universitaria presentó un proyecto para difundir a través de este portal las colecciones digitales existentes en el archivo, por lo que se dispuso a crear el canal web: http://www.youtube.com/uaslptv; además, tiene otro proyecto para acopiar las muestras de video de la Red Nacional de Televisión y Video de las Instituciones de Educación Superior el canal 
web https://www.youtube.com/redtvIES. Dichos canales se han consolidado dentro y fuera de la universidad y se constituyen como una fuente de referencia.

En un análisis realizado desde la videoteca de Televisión Universitaria en el mes de septiembre de 2016 a algunas universidades autónomas del país que utilizan esta plataforma de videos, se pudieron constatar las siguientes cantidades de reproducción de videos que se han difundido en sus canales más representativos: ver páginas 77-78.

Aunque las cantidades puedan ser mínimas a nivel general, estos esfuerzos por difundir el conocimiento se vuelven representativos y de vital importancia para la suma en el proceso de enseñanza-aprendizaje en México. Es necesario resaltar que las universidades privadas también han hecho esfuerzos importantes de difusión y acceso de contenidos videográficos a través de canales propios en YouTube.

Desde el año 2015, en apoyo a la Federación Internacional de Archivos de Televisión (FIAT), se empezó a trabajar en una campaña de concientización acerca de la preservación del patrimonio audiovisual, y se han llevado a cabo una serie de acciones a favor de esta tarea como talleres, ponencias, rescate de material videográfico, intervenciones en radio y televisión, así como entrevistas a especialistas en documentación audiovisual del ámbito local, nacional e internacional. En el canal web en YouTube se creó un apartado para difundir dichas entrevistas, el cual puede ser consultado en la siguiente liga: https://www.youtube.com/ playlist?list=PLmMt7bThgLunJe9JZjticJQDpApBsrOBb.

Este esfuerzo ha tenido respuestas favorables, no sólo a nivel local, sino también a nivel nacional e internacional. Diversas organizaciones han reconocido y difundido dichas actividades en pro del patrimonio audiovisual. 


\begin{tabular}{|c|c|}
\hline Nombre & Reproducciones \\
\hline Universidad Nacional Autónoma de México & $2,384,059$ \\
\hline Universidad Autónoma de San Luis Potosí & $1,242,261$ \\
\hline Universidad Autónoma de Guadalajara & $1,196,428$ \\
\hline Universidad Autónoma de Nuevo León & $1,029,392$ \\
\hline Benemerita Universidad Autónoma de Puebla & 799,554 \\
\hline Universidad Autónoma de Nayarit & 662,789 \\
\hline Universidad Veracruzana & 633,895 \\
\hline Universidad Autónoma de Tamaulipas & 533,325 \\
\hline Universidad Autónoma de Baja California & 487,395 \\
\hline Universidad Autónoma de Chihuahua & 457,542 \\
\hline Universidad de Colima & 432,677 \\
\hline Universidad Autónoma de Zacatecas & 266,170 \\
\hline Universidad de Guadalajara & 239,663 \\
\hline Universidad Juarez Autónoma de Tabasco & 221,622 \\
\hline Universidad Autónoma de Yucatán & 194,878 \\
\hline Universidad de Guanajuato & 180,176 \\
\hline Universidad Autónoma de Querétaro & 177,928 \\
\hline Universidad Autónoma de Morelos & 126,788 \\
\hline Universidad Autónoma de Guerrero & 102,253 \\
\hline Universidad de Sonora & 100,318 \\
\hline Universidad Autónoma de Sinaloa & 93,584 \\
\hline Universidad Autónoma de Aguascalientes & 54,105 \\
\hline Universidad Autónoma de Coahuila & 31,861 \\
\hline Universidad Autónoma del Estado de México & 31,328 \\
\hline Universidad Autónoma de Chiapas & 29,595 \\
\hline Universidad Autónoma de Durango & 28,789 \\
\hline Universidad Autónoma Benito Júarez de Oaxaca & 28,464 \\
\hline Universidad Autónoma del Estado de Hidalgo & 20,813 \\
\hline Universidad Michoacana San Nicolás de Hidalgo & 17,666 \\
\hline Universidad Autónoma de Campeche & 8,150 \\
\hline Universidad de Quintana Roo & 8,050 \\
\hline Universidad Autónoma de Tlaxcala & 5,102 \\
\hline
\end{tabular}

Imagen de videoteca de TVUASLP (2016). 


\section{- Reproducciones}

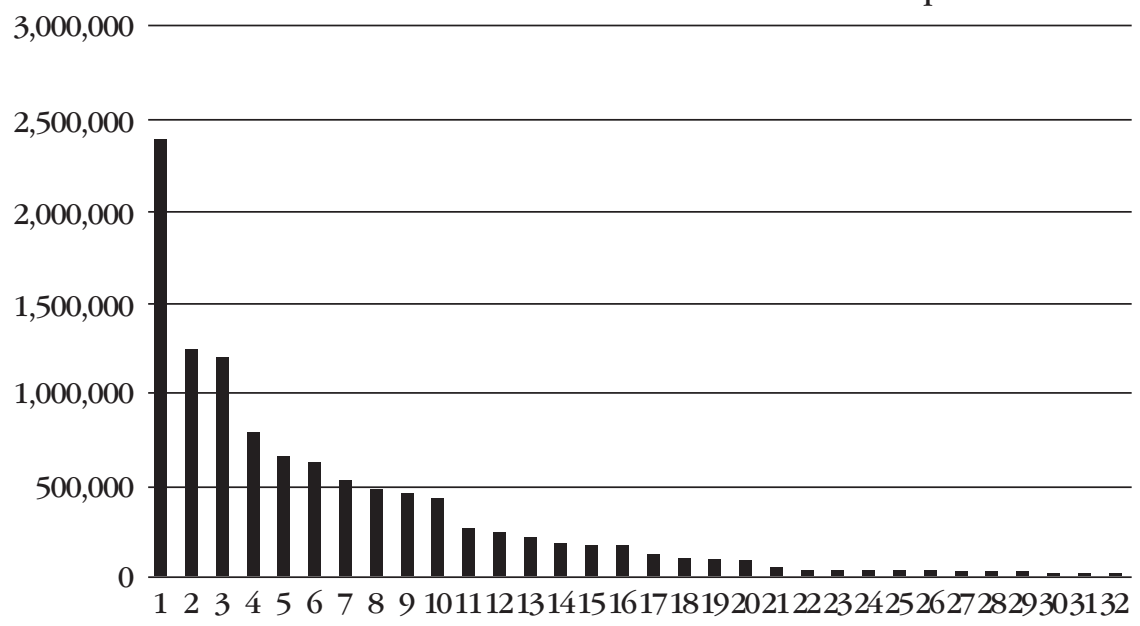

Imagen de videoteca de TVUASLP (2016).

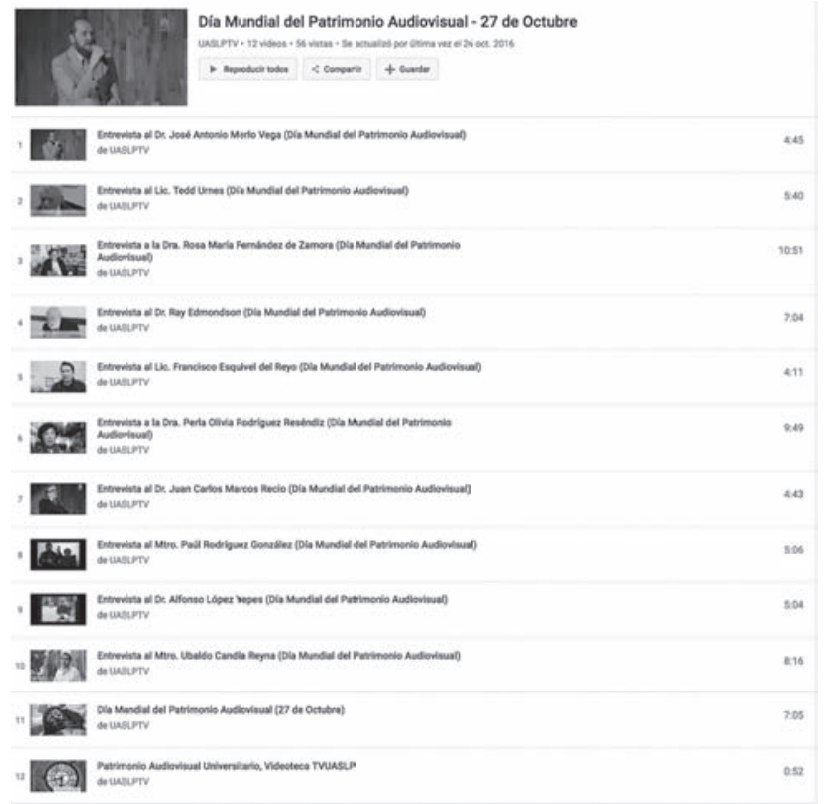

Imagen de videoteca de TvuAslp (2016). 


\section{Conclusiones}

En todos los países se han perdido o han desaparecido documentos audiovisuales que por su contenido y valor histórico son de gran relevancia. Preservar la memoria y el patrimonio videográfico no es una tarea fácil, tomando en cuenta que en muchas partes no existe la consciencia de conservar y hacer accesible un documento, como también en muchos casos no se cuenta con la infraestructura ni el personal adecuado para dicho fin.

En los archivos de televisión se concentran grandes cantidades de imágenes en movimiento, muchas de ellas son imágenes únicas. La Unesco considera que su importancia trasciende los límites del tiempo y la cultura, y que deben preservarse para las generaciones actuales y futuras y ser puestas de alguna forma a disposición de todos los pueblos del mundo.

La demanda de acceso propia de la sociedad de la información estimula la labor de preservación. Los profesionales de la información como bibliotecólogos, archivistas, documentalistas, entre otros, deben asumir el reto de preservar y constituir patrimonios, y considerar que se tendrán que buscar todas las opciones posibles para hacer de esta labor una realidad.

La Unesco ha solicitado a todos los estados miembros (incluido México), a los productores y consumidores de imágenes y de sonidos y a las instituciones encargadas de salvaguardarlos que unan sus fuerzas para proteger y compartir la riqueza audiovisual que tenemos en común.

Se han realizado esfuerzos significativos a nivel nacional; parte del trabajo que se ha realizado en la videoteca de TV UASLP se enfoca en incrementar la consciencia y protección del patrimonio videográfico y lograr su accesibilidad permanente. 


\section{Bibliografía}

Del Valle-Gastaminza, F. (2011). Reseña del libro "Documentación audiovisual: Nuevas tendencias en el entorno digital". Revista Española de Documentación Científica en línea. Disponible el 22 de septiembre de 2016 en: http://redc.revistas.csic.es.

Documanía 2.0 (2013). "Cuánta información se genera y almacena en el mundo". Entrada del16 de septiembre de 2013. Disponible el 22 de septiembre de 2016 en: https://documania20. wordpress.com/2013/09/16/cuanta-informacion-se-genera-y almacena-en-el-mundo/.

Domo (2012). “¿Cuántos datos se crean cada minuto?”. Disponible el 22 de septiembre de 2016 en: http://domo.com/blog/how-muchdata-is-created-every-minute/.

Edmondson, R. (2004). Filosofía y principios de los archivos audiovisuales. París: Unesco. Disponible el 22 de septiembre de 2016 en: http://unesdoc.unesco.org/images/0013/001364/136477s. pdf.

Marcos Recio, J.C. (2013). Gestión del patrimonio audiovisual en medios de Comunicación. Madrid: Síntesis.

Martínez Odriozola, E. (1992). La televisión pública como servicio esencial, el archivo audiovisual. Congreso y Conferencia FID. España: RTVE.

Red Nacional de Televisión y Video de las IEs. (2016). Canal web de YouTube. Disponible el 19 de septiembre de 2016 en: https:// www.youtube.com/redtvIES.

Televisión Universitaria UASLP. (2016). Canal web de Youtube. Disponible el 19 de septiembre de 2016 en: https://www.youtube. com/UASLPTV.

Unesco (2015). Mensaje de Irina Bokova, directora general de la Unesco, con motivo del Día mundial del patrimonio audiovisual. 27 de octubre de 2015. Disponible el 20 de septiembre de 2016 en: http://unesdoc.unesco.org/images/0023/002350/235072s.pdf. 
(2005). Día mundial del patrimonio audiovisual. Disponible el 20 de septiembre de 2016 en http://unesco.org/new/es/communication-and-information/access-to-knowledge/archives/ world-day-for-audiovisual-heritage/.

(2003a). Directrices para la preservación del patrimonio digital. Camberra, Australia: Biblioteca Nacional de Australia. Disponible el 19 de septiembre de 2016 en: http://unesdoc. unesco.org/images/0013/001300/130071s.pdf.

(2003b). Carta sobre la preservación del patrimonio digital. París: Unesco. Disponible el 21 de septiembre de 2016 en: http:// portal.unesco.org/es/ev.phpurL_ID=17721\&URL_DO=DO_TOPIC\&URL_SECTION=201.html.

(2002). Memoria del mundo, directrices para la salvaguardia del patrimonio documental. Disponible el 21 de septiembre de 2016 en: http://unesdoc.unesco.org/images/0012/001256/125637s.pdf.

(1980). Recomendación sobre la salvaguardia y la conservación de las imágenes en movimiento. Disponible el 26 de septiembre de 2016 en: http://portal.unesco.org/es/ev.php-urL_ ID=13139\&URL_DO=DO_TOPIC\&URL_SECTION=201.html. 


\section{La industria de los contenidos en el sector editorial}




\title{
La industria de los contenidos en el sector editorial: contenidos, soportes, modelos de negocio, creatividad e innovación
}

\author{
Jenny Terestita Guerra González \\ Instituto de Investigaciones Bibliotecológicas y de la Información
}

UNAM

\section{INTRODUCCIÓN}

T a génesis de la industria editorial aconteció en el último tercio del siglo XIX con la automatización de la imprenta. Antes de ese periodo es pertinente referirnos a la edición como una práctica artesanal caracterizada por la participación de libreros como editores; y élites económicas y políticas como compradores y lectores de las obras. La automatización del proceso permitió una creciente aparición de revistas literarias, políticas y científicas como productos editoriales, y una comercialización que combinaba la suscripción, la venta directa y la publicación por entregas. De aquel momento a la fecha, el ámbito editorial ha pasado por diferentes etapas vinculadas con los cambios sociales, económicos, políticos y tecnológicos de carácter nacional e internacional. Con el auge de las Tecnologías de la Información y la Comunicación (TICS) y la paulatina masificación de Internet a finales de los años noventa del siglo xx, la industria de los contenidos alcanza al sector editorial, lo trastoca y enriquece. 
La industria de los contenidos - media and content industries en el contexto anglosajón - es conceptualizada como "la conjunción de sectores y actividades vinculados a las publicaciones (libros, periódicos, etc.), al cine y vídeo, a la música (grabación y edición), la creación y emisión de programas de Radio y Televisión, así como también a los videojuegos" (Cuenta Satélite de la Cultura, 2014). Otras acepciones de la industria son: a) producción pensada para las Tecnologías de la Información y la Comunicación (TICS), que convergen con lo digital y plantean la inclusión social (Castro, 2008: 15-18); b) empresas que generan, procesan y distribuyen información en formato electrónico (Mañà, 2000: 4), y c) "an umbrella term that encompasses companies owning and providing mass media, and media metadata" (Jahankhani, 2010: 483).

Entre las características que identifican a la industria de los contenidos, están:

- Se basa en la infraestructura de las telecomunicaciones porque circula a través de éstas.

- Hace posible la personalización de los contenidos debido a su flexibilidad y convergencia.

- Se apoya en un marco legal adaptado a las nuevas características de la información y sus mecanismos de transmisión.

- Para su óptimo desempeño requiere de velocidad de acceso (ancho de banda amplio) que facilite la diseminación de contenidos con alta calidad de visualización y que permita la interactividad con los usuarios.

- Faculta el cambio en los roles tradicionales del ecosistema de la infocomunicación.

- Internet se posiciona como un elemento dinamizador al romper con las barreras espacio-temporales y permitir el consumo de contenidos sin depender del espacio geográfico en que se enmarca su producción ni del momento en que se distribuyen. 
- Las redes sociales se convierten en una herramienta valiosa para que los usuarios participen en el proceso de creación y redistribución de los contenidos (Vivar-Zurita y Vinader-Segura, 2011; Feijóo, 2013).

Un rasgo particular de la industria de los contenidos es que sus sectores presentan una importancia y peso económicos desiguales en función de las distintas áreas geográficas existentes. Así como en Estados Unidos el cine y el audiovisual copan el mercado, en Asia-Pacífico se imponen los videojuegos y en Europa los sectores editorial y de la música marcan la pauta.

En ese sentido, se habla del sector editorial como parte de la industria de los contenidos en la medida en que trabaja como un ecosistema con especialización de sus eslabones productivos, con intervención constante del consumidor en los contenidos ofertados (interacción/producción) y la trascendencia del texto más allá del formato libro.

EL SECTOR EDITORIAL EN SUS CONTENIDOS, SOPORTES Y MODELOS DE NEGOCIO

La edición contemporánea cuenta con subsectores como la edición académica, científico-técnica, didáctica, comercial e independiente que se encuentran definidos a partir de sus contenidos, soportes y modelos de negocio.

Los contenidos son elementos de conocimiento, información, comunicación y cultura que en el escenario digital se estructuran por bits y bytes. Agrupan la creación literaria, la información científica y académica, los datos económicos, y los productos culturales y de entretenimiento. El contenido se pluraliza en multiformatos (aplicaciones para celular, fotografías, e-books, podcast, videos y revistas) para garantizar la compatibilidad, movilidad, convergencia y horizontalidad cuando sus administradores se ven condicionados por las 
lógicas de los mercados y la innovación disruptiva en el terreno de los dispositivos tecnológicos (Abadal y Ollé, 2013; Vivar-Zurita y Vinader-Segura, 2011).

Los soportes son la materialización tecnológica que hace posible la transmisión, reproducción y almacenamiento de los contenidos digitales. Ejemplos de estos son los e-readers, los servidores, teléfonos móviles, tabletas, computadoras personales y consolas de videojuegos (Formatos de difusión, 2011). La unión de contenidos y soportes contribuyen a la creación e implementación de modelos de negocio en las industrias de contenidos y, por antonomasia, en el sector de la edición.

Un modelo de negocio se entiende como la lógica elegida por la empresa para crear y comercializar valor (Leminen et al., 2006: 188). Los modelos de negocio constan de elementos como la relación de aspectos materiales los sistemas de creencias y la evolución de la organización. En el caso del sector editorial, asistimos a un cambio crítico en el sistema de creencias que es producto de la continua transformación y convergencia de las industrias de medios debido a la digitalización del contenido, lo cual incide en sus procesos de gestión. Acorde a esta tónica, subsectores editoriales como el didáctico, el académico, el científico y el comercial tienden a transformarse de proveedores de materiales a prestadores de servicios digitales. Dicha conversión se conoce como extensión del modelo de negocio - business model extension - y se efectúa cuando una compañía agrega nuevos procesos a su modelo. Un ejemplo sería la ampliación del portafolio de negocios de una editorial de los productos impresos a los digitales o a aquellos que se imprimen bajo demanda.

Actualmente, podemos hablar de la existencia de cuatro modelos de negocio en el sector editorial —que están o no 
presentes en otros sectores de la industria de contenidos (Celaya, 2014). El primero de éstos es el acceso abierto (open access), que permite la consulta en línea de manera gratuita sin restricciones técnicas o legales de libros, revistas, folletos y portales interactivos con el propósito de promover su difusión. La edición académica de carácter universitario es un subsector que ha explotado mayormente este modelo de forma creciente a partir de 1990, en la medida en que los fondos con los que lleva a cabo sus procesos de publicación, investigación y/o docencia provienen de fondos públicos. Cada vez más países cuentan con reglamentaciones nacionales que condicionan a sus instituciones educativas y de investigación estatales a disponer sus productos editoriales en portales y plataformas en línea para que el conjunto de la sociedad pueda consultarlos, descargarlos y, en ciertos casos, reelaborarlos en productos o servicios derivados. En México, existen los Lineamientos generales para el repositorio nacional y los repositorios institucionales; en España, la Ley 14/2011 de la ciencia, la tecnología y la innovación; en Perú, la Ley No. 30035 que regula el Repositorio Nacional Digital de Ciencia, Tecnología e Innovación de Acceso Abierto, y en Estados Unidos la National Institutes of Health Public Access Policy. El acceso abierto es eficaz para la edición académica universitaria porque ésta suele perseguir la rentabilidad cultural y social más que la económica. Sus contenidos son publicados por la relevancia y contribución al conocimiento que aportan. Las denominadas Open Access Citation Advantage (OACA) resumen las ventajas que tiene este modelo en el impacto y la citación de los contenidos académicos vía valores añadidos como la indización, los metadatos, la gestión de los derechos de autor y la preservación para la disponibilidad a largo plazo (Abadal y Ollé, 2013: 17, 58, 62; Rius, 2012). 
El segundo es el modelo de suscripción, en el cual el cliente o usuario paga por el acceso a un producto o servicio con una periodicidad fijada y acordada de antemano. Los periódicos y las revistas han sido los primeros en desarrollar modelos de suscripción de diferente naturaleza. Las revistas científicas representan casos ejemplares de este modelo en la edición en tanto que su publicación se lleva a cabo por grandes grupos como Elsevier, Thomson Reuters o Springer, y su gestión y venta es emprendida por agencias de suscripciones del tipo de Ebsco y Swets (Romero Otero, Giménez Toledo y Martín-González, 2010: 21-22). Por el contrario, los e-books científico-técnicos apenas están despegando, pues a sus colecciones y títulos se suscriben básicamente bibliotecas universitarias e instituciones académicas que pagan cuotas anuales, ${ }^{3}$ mientras que en el subsector de la edición comercial sólo recientemente se ha puesto en marcha la suscripción por parte de proveedores de contenido y, de forma más limitada, de las editoriales. ${ }^{4}$

La empresa española 24 symbols, conocida como "el Spotify de los libros", fue pionera en la implementación de este modelo de negocio. En 2014, Amazon lanzó Kindle Unlimited, un servicio de suscripción para dispositivos con soporte Kindle - tablet, iPad, smartphone-, en el que la plataforma ofrece miles de $e$-books y libros de audio por una cuota mensual. A esta iniciativa se han sumado portales españoles como

3 En el subsector científico-técnico hay una mayor oferta de libros y otros productos editoriales de las ciencias exactas y naturales que en el de las humanidades y ciencias sociales, resultado de la demanda que subyace a las primeras disciplinas.

4 Grupo Planeta en colaboración con Telefónica lanzó en 2013 la plataforma de suscripción Nubico. Nubico permite al usuario explorar los e-books de su catálogo y añadirlos, o acceder a una muestra de sus primeros capítulos y descargar apps de lectura gratuita para tablets y smartphones. El sitio de Nubico se encuentra disponible en https://www.nubico.es/. 
Libros del Aire, Ediciones ENI y Sans Soleil Ediciones; Scribd, Playster y Just the Right Book en el mercado anglosajón, y en el área latinoamericana Nube de Libros (portal brasileño con presencia en España) y Novelistik (plataforma mexicana de publicaciones y lectura digital). Tanto en el subsector comercial como en el científico-técnico, se tienen que diseñar licencias que regulen los derechos sobre la consulta y descarga de los contenidos que contraten lectores e instituciones ${ }^{5}$ (Marín, 2014; Mellado, 2014; Picchi, 2016).

La oferta sumada al precio y al servicio son los factores clave en el éxito de las librerías/plataformas que eligen la suscripción como opción de venta. Estas empresas tendrán que enfrentar dos retos importantes: la negociación constante con múltiples editoriales para la adquisición de contenido de novedad, y la competencia con las bibliotecas que conjugan el préstamo de materiales digitales e impresos con la ventaja de la gratuidad.

Por otra parte, el modelo freemium consiste en ofrecer algún producto o contenido de manera gratuita mientras que para tener acceso a otra parte de los contenidos hay que pagar (servicio Premium). En ocasiones, este modelo incluye publicidad o mercadotecnia agregada a dichos contenidos, en espera de que los ingresos provenientes los consumidores Premium sustenten el negocio. El freemium ha funcionado en la web dese tiempo atrás en industrias de contenidos como videojuegos y sitios de información periodística, y fue hasta 2008 que empezó a ser considerado por los editores (Vázquez, 2009). Open Edition y Google Play Books son

5 Entre las opciones que presentan las licencias de suscripción, encontramos que pueden limitar el acceso a un número concreto de usuarios simultáneos; la descarga e impresión tiene variantes en cuanto a número de páginas o capítulos; algunas veces establecen restricciones de acceso a lo largo del tiempo, etcétera. 
ejemplos de iniciativas editoriales que emplean el modelo. La primera es un portal del Centro para la Edición Electrónica Abierta, institución asociada al Centro Nacional de la Investigación Científica de Francia, a la Universidad de Aix-Marseille y a la Escuela de Estudios Superiores de la Universidad de Avignon y de los países de Vaucluse. Open Edition agrupa libros y revistas de editores académicos y científicos mayoritariamente franceses —aunque también hay presencia de italianos, españoles, colombianos y mexicanos - publicados en diez idiomas. Se permite la consulta de su introducción, fragmentos de capítulos y artículos de manera gratuita pero las descargas del texto completo en epUB y PDF tienen un costo; incluso hay materiales que disponen de una versión impresa.

Google combina en la app Google Play Books tanto la disposición de obras completas (de dominio público/común y bajo licencias abiertas/libres) como muestras gratis de libros - con un nivel mínimo de acceso- de géneros que incluyen arte y diversión; biografías y memorias; finanzas e inversión; novela romántica, etc. Al actuar como una plataforma, los libros provienen de diferentes editoriales de tamaños, subsectores y países diversos que se suman a la oferta de la empresa de Internet en una suerte de sistema integrado de contenidos comercializables potenciado por las soluciones tecnológicas (Vercelli, 2012: 6; Castellet, Aguado y Martínez, 2013).

Otro caso es el crowdfunding, que se define como un sistema de cooperación colectiva en el que un grupo de personas apoya económicamente iniciativas de otros individuos $\mathrm{u}$ organizaciones. Como las aportaciones suelen consistir en pequeñas cantidades pero éstas son muy numerosas, al contar con distintos "mecenas" se habla de micromecenazgo. Este modelo de negocio se lleva a cabo por medio de plataformas en línea que permiten canalizar la financiación a dife- 
rentes proyectos que incluyen moda, música, cultura, eventos deportivos, medio ambiente, etc. (Universo crowdfunding, 2013). Las formas de financiación, basadas en el micromecenazgo, son: pago en productos, ventajas, ofertas y participaciones. Bookolia es una editorial independiente española que publica novela gráfica, narrativa tradicional y poesía en un régimen de coedición a partir de su propio canal de crowdfunding: http://www.verkami.com/partners/46-bookolia-editorial. Por medio de este espacio en línea, la editorial, en conjunto con los autores, establece un presupuesto - monto o meta a alcanzar - para la edición, el tiraje, el envío y la promoción de los títulos que los interesados pueden consultar y optar por apoyar (Rueda, 2016). En América Latina, autores como el uruguayo Diego Marín, el argentino Martín Rumbo y el brasileño Leonardo Malinowski han utilizado las plataformas de crowdfunding de las editoriales Pentian, Idea-me y Benfeitoria para publicar novelas, libros de cuentos y libros interactivos entre otros géneros literarios.

El desarrollo de esta creciente y divergente oferta de contenidos, soportes y modelos de negocio responde a factores como la fragmentación de las audiencias, las preferencias de los consumidores por determinados dispositivos tecnológicos, y la colaboración conjunta para la supervivencia y crecimiento de empresas y organizaciones editoriales.

\section{LA CREATIVIDAD Y LA INNOVACIÓN COMO}

\section{INSUMOS DEL DESARROLLO DE CONTENIDOS EDITORIALES}

Las personas y su creatividad son dos elementos fundamentales para la creación innovadora de contenidos digitales de índole editorial, llámense productos, plataformas para la distribución y/o comercialización, nuevos formatos y modelos de negocio, estrategias de producción, etcétera. La creatividad, 
entendida como la capacidad de los individuos para generar nuevas ideas, presenta una dimensión económica, sociológica y psicológica. Por su parte, la innovación se refiere a la ruptura con las rutinas establecidas en el ámbito productivo. La creatividad se adjetiva como innovadora cuando cuestiona cualquier orden instituido, pues consiste en hacer aparecer algo imprevisto (Florida, 2009: 32; Bergua Amores, Pac Salas, Baéz Melián y Serrano Martínez, 2016: 1).

Extrapolando los conceptos de creatividad e innovación al sector editorial, nos topamos de inmediato con la necesidad de contar con especialistas que posean estas habilidades para que se traduzcan en cadenas de valores flexibles y sostenibles. Cualquier subsector editorial productor de contenidos digitales requerirá de personal creativo que conjugue saberes y prácticas en materia de tecnología, talento y tolerancia. El cuadro 1 congrega algunas nuevas profesiones que han emergido en los últimos cinco años como resultado de las demandas de la industria editorial.

Si bien las profesiones y los roles nuevos de los actores del sector editorial evidencian una industria en constante evolución y diversificación, también tenemos que ponderar sus desventajas en cuanto a la pauperización de la labor editorial, su influencia en la construcción y percepción de la cultura escrita y la constante búsqueda de legitimidad de prácticas e intervenciones que se suelen ver como una moda más de las comunidades juveniles alternativas (Schavelzon, 2013; Rodríguez, 2007).

\section{RECOMENDACIONES Y CONCLUSIONES}

La industria de los contenidos digitales representa una parte fundamental en las sociedades modernas por su doble papel de instrumento de creación de la riqueza en el contexto de 


\begin{tabular}{|c|c|c|}
\hline $\begin{array}{c}\text { Nombre de la } \\
\text { profesión }\end{array}$ & $\begin{array}{l}\text { Habilidades } \\
\text { tecnológicas }\end{array}$ & $\begin{array}{l}\text { Habilidades creativas } \\
\text { (talento y tolerancia) }\end{array}$ \\
\hline $\begin{array}{l}\text { Gestor de proyectos } \\
\text { editoriales online }\end{array}$ & $\begin{array}{l}\text { Conocimiento de } \\
\text { Microsoft Project y } \\
\text { OpenProj }\end{array}$ & $\begin{array}{l}\text { Comunicarse de forma } \\
\text { satisfactoria, capacidad de } \\
\text { negociación y de resolución } \\
\text { de conflictos } \\
\text { Transmitir motivación }\end{array}$ \\
\hline $\begin{array}{l}\text { Desarrollador de } \\
\text { aplicaciones móviles }\end{array}$ & $\begin{array}{l}\text { Manejo de entornos } \\
\text { de desarrollo } \\
\text { integrado (Eclipse, } \\
\text { NetBeans, Intelli } \\
\text { IDEA, JDeveloper) }\end{array}$ & $\begin{array}{l}\text { Liderazgo } \\
\text { Proactividad } \\
\text { Capacidad de colaboración } \\
\text { y trabajo en equipo } \\
\text { Transmitir motivación }\end{array}$ \\
\hline $\begin{array}{l}\text { Editor-curador de } \\
\text { contenidos }\end{array}$ & $\begin{array}{l}\text { Conocimiento de } \\
\text { herramientas de } \\
\text { curaduría así como } \\
\text { de agregadores de } \\
\text { contenidos }\end{array}$ & $\begin{array}{l}\text { Curiosidad y actitud de } \\
\text { aprendizaje permanente } \\
\text { Capacidad de síntesis } \\
\text { Actitud crítica y empática }\end{array}$ \\
\hline $\begin{array}{l}\text { Editor de servicios } \\
\text { y contenidos } \\
\text { multimedia }\end{array}$ & $\begin{array}{l}\text { Conocimientos de } \\
\text { programación en } \\
\text { Adobe y en HTML5 } \\
\text { Conocimiento de } \\
\text { editores de video y } \\
\text { audio }\end{array}$ & $\begin{array}{l}\text { Emprendedor } \\
\text { Colaborativo } \\
\text { Curiosidad y actitud de } \\
\text { aprendizaje permanente }\end{array}$ \\
\hline $\begin{array}{l}\text { Diseñador de libros } \\
\text { digitales infantiles }\end{array}$ & $\begin{array}{l}\text { Programación } \\
\text { orientada a objetos } \\
\text { Conocimiento de } \\
\text { lenguajes xML, } \\
\text { Java Script y CSharp }\end{array}$ & $\begin{array}{l}\text { Planeación } \\
\text { Trabajo en equipo } \\
\text { Privilegia el diálogo y la } \\
\text { comunicación; colaborativo } \\
\text { Curiosidad y actitud de } \\
\text { aprendizaje permanente } \\
\text { Incluyente }\end{array}$ \\
\hline
\end{tabular}

Cuadro 1. Nuevas profesiones en la industria editorial.

Fuente: elaboración propia con información de Del Amo (2016), Domínguez (2011) y Morante Bonet (2013). 
la economía del conocimiento, y de motor de la Sociedad de la Información. Teniendo en cuenta que ésta va a seguir transformándose, es necesaria la investigación, identificación y análisis de la oferta y la demanda de sus contenidos.

No existen recetas mágicas para encaminar al éxito a los distintos subsectores de la edición contemporánea. El contexto en que cada uno de ellos se desenvuelve es disímil, su circunstancias y estructuras organizacionales también. Como dice Joaquín Rodríguez en Edición 2.0: los futuros del libro, "no existe un futuro unilateral del libro. Existen futuros del libro porque existen varios tipos de libros y de contenidos en soportes a los que podemos denominar libros" (:28).

A lo que sí se puede apostar es a mantener la función del valor añadido que las prácticas editoriales dan al trabajo creativo inicial, ése que corresponde al autor. Simultáneamente, hay que concebirse como creadores y reintermediarios con un papel determinante en la definición y posibilidades de estructuración de una obra, su difusión y/o comercialización en los soportes, formatos y mercados que se consideren en la planificación previa.

Como señala el informe Staining Scholarly Publishing: New Business Models for University Press (Withey, 2011) de la Association of American University Presses, además de los nuevos modelos de negocio, actores, contenidos y soportes, también surgen nuevos riesgos y dependencias en la edición. Aquí una guía breve de recomendaciones que podrían tomar en cuenta editores de todos tamaños, subsectores y nacionalidades:

a) Incorporar las innovaciones tecnológicas de manera inteligente.

b) Ponderar la adaptabilidad de las publicaciones a los dispositivos disponibles en el mercado.

c) Contemplar e implementar un plan de preservación digital de 
los originales de las obras y de todo el proceso de producción, además de sus distintas versiones para distribuir y comercializar. d) Crear estrategias para construir comunidades de lectores.

e) Establecer redes de apoyo con otras editoriales y sobre todo, con las librerías o plataformas de distribución y comercialización de contenidos.

f) Ajustar los planes editoriales a los momentos de coyuntura económica sin crear un desequilibrio que merme la calidad.

g) Desarrollar sinergias con bibliotecas, museos e instituciones u organizaciones vinculadas con los temas del catálogo.

h) Monitorear al lector.

i) Prestar atención a la demanda de contenidos mixtos (con versión impresa y digital, cuya narrativa sea transmedial, que cuenten con agregados multimedia).

j) Regionalizar su oferta de acuerdo con la demanda de contenidos locales.

k) Apuntar a la coherencia entre promoción y estrategia de precios.

1) No sólo comercializar contenidos como productos editoriales, ampliar en la medida de lo posible la venta de servicios a autores, otras editoriales o instituciones de diversa índole.

\section{BIBLIOGRAFÍA}

Abadal, E. y Ollé, C. (2013). La edición universitaria en el contexto de la ciencia abierta. Barcelona: Editorial UOC.

Bergua Amores, J.A. et al. (2016). "La clase creativa. Una aproximación a la realidad española". Revista Internacional de Sociología, 74 (2), 1-19. Disponible en: http://revintsociologia.revistas.csic.es/index.php/revintsociologia/article/viewArticle/645. 
Borghino, J. y B. Steward (2016). "La empresa editorial y la economía digital". Revista de la OMPI, 3, 32-36. Disponible en: http:// www.wipo.int/wipo_magazine/es/2016/03/article_0007.html.

Castellet, Aguado y Martínez (2013). "Los nuevos actores que cambian las reglas y el juego: cómo Apple y Google han transformado la distribución de contenidos". VII International Conference on Communication and Reality. Barcelona: Universidad Ramón Llull. Disponible en: http://cicr.blanquerna. edu/wp-content/uploads/2014/09/cicr2013english.pdf

Castro, C. (2008). Industrias de contenidos en Latinoamérica. Buenos Aires: CEPAL.

Celaya, J. (2014). Nuevos modelos de negocio en la Era Digital. Barcelona: Dosdoce. Disponible en: http://www.dosdoce.com/ upload/ficheros/noticias/201409/modelos_de_negocio_pdf.pdf.

Cuenta Satélite de la Cultura (2014). Madrid: Observatorio Nacional de las Telecomunicaciones y de la Sociedad de la Información de España. Disponible en: http://www.mecd.gob.es/ servicios-al-ciudadano-mecd/gl/dms/mecd/servicios-al-ciudadano-mecd/estadisticas/cultura/mc/naec/2014/capitulos/Cuenta_satelite_cultura_2014_metodologia.pdf.

Del Amo, E. (2016). "Trabajar en el mundo editorial: carreras que aman las letras". Entrada en el blog Empleo de Aprendemas. com. Disponible en: http://www.aprendemas.com/es/blog/ empleo/trabajar-en-el-mundo-editorial-carreras-que-aman-lasletras/.

Domínguez, E. (2011). "Editores de contenidos multimedia". Entrada en el blog El Cuarto Bit. Notas sobre Comunicación y Nuevas Tecnologías. Disponible en: http://blogs.lavanguardia. com/elcuartobit/editores-de-contenidos-multimedia.

Feijóo, C. (2013). "Soportes digitales y transformación de las industrias de contenidos”. El profesional de la información, 22 (1), 5-9. Disponible en: http://www.elprofesionaldelainformacion. com/contenidos/2013/enero/01.html. 
Florida, R. (2009). La clase creativa. La transformación de la cultura del trabajo y el ocio en el siglo XXI. Barcelona: Paidós.

Formatos de difusión y formatos de preservación de contenidos digitales (2011). San Sebastián: Observatorio Vasco de la Cultura. Disponible en: http://www.kultura.ejgv.euskadi.eus/contenidos/informacion/kultura2_0_prestakuntza/es_k20_form/ adjuntos/cuaderno-DIG-52.pdf.

Giménez-Toledo, E. (2014). "Imposturas en el ecosistema de la publicación científica". Revista de Investigación Educativa, 32 (1), 13-23. Recuperado desde: http://revistas.um.es/rie/article/ view/190251/158261.

Hibbert, B. (1999). "Publishing and the Media Industries in the Digital Age”. Info, 1 (5), 393-403. Disponible en: http://www. emeraldinsight.com/doi/abs/10.1108/14636699910801151.

Jahankhani, H. (2010). Handbook of Electronic Security and Digital Forensics. Londres: World Scientific Publishing.

Leminen, S. et al. (2016). "Business Model Convergence and Divergence in Publishing Industries". Media Convergence Handbook, 1. Disponible en: http://link.springer.com/chapter/10.10 07\%2F978-3-642-54484-2_11.

Mañà, F. (2000). "Posibles escenarios para las industrias digitales". El Profesional de la Información, 9 (1-2), 4-10. Disponible en: http://eprints.rclis.org/11162/1/02.pdf.

Marín, E. (2014). "Amazon ofrecerá libros mediante suscripción: un Netflix para Kindle”. Hipertextual. Recuperado desde: https:// hipertextual.com/2014/07/amazon-kindle-unlimited.

Mellado, A. (2014). “Será la suscripción el principal modelo de negocio del libro?". Anatomía de la Edición. Entrada del 28 de octubre de 2014 disponible en: http://www.actualidadeditorial.com/suscripcion-futuro-modelo-de-negocio-del-libro/.

Morante Bonet, M. (2013). Diseño de libros infantiles digitales. Proyecto Final de Master en Producción Artística. Valencia: Facultad de 
Belles Arts Sant Carles/Universidad de Valencia. Disponible en: https://riunet.upv.es/bitstream/handle/10251/27807/TFM_LibroDigitalInfantil.pdf.

Picchi, A. (2016). "Should you Consider an e-book Subscripcion. Think about Selection and Price". Consumer Reports. Disponible en: http://www.consumerreports.org/money/consider-an-ebook-subscription/.

Plataforma Universo Crowdfunding (2013). "¿Qué es el crowdfunding?”. Disponible en: http://www.universocrowdfunding.com/.

Rius, L. (2012). "A las editoriales universitarias les faltan nuevos modelos". Entrada en el blog BID. Disponible en: http://www.ub.edu/ blokdebid/es/content/las-editoriales-universitarias-les-faltan-nuevos-modelos.

Rodríguez, J. (2007). Edición 2.0: los futuros del libro. Barcelona: Melusina.

Romero-Otero, I.S., E. Giménez-Toledo y J.C. Martín-González (2010). "El e-book científico-técnico en el mercado español a partir del análisis de las agencias de suscripciones". El Profesional de la Información, 19 (1), 21-27. Disponible en: http://recyt.fecyt. es/index.php/EPI/article/view/epi.2010.ene.03/21324.

Rueda, C. (2016). "Una editorial que ayuda a publicar con crowdfunding". Entrada en el blog Capeando la Crisis. Disponible en: http://blogs.20minutos.es/capeando-la-crisis/2016/05/24/ una-editorial-que-ayuda-a-publicar-con-crowdfunding/.

Schavelzon, G. (2013). "El nuevo rol del editor y el futuro del libro y la industria editorial". Trama \& Texturas, 21, 47-58. Disponible en: http://www.revistasculturales.com/xrevistas/PDF/127/1671.pdf.

Vázquez, J.A. (2009). “'Freemium' un nuevo modelo de negocio editorial”. Entrada en el blog Dosdoce. Disponible en: http://www. dosdoce.com/2009/09/28/freemium-un-nuevo-modelo-de-negocio-editorial/. 
Vercelli, A. (2012). "Google Books y los cambios en las industrias editoriales". Educación Superior y Sociedad, 16 (2), 1-12. Disponible en: http://ess.iesalc.unesco.org.ve/index.php/ess/article/view/403/341.

Vivar-Zurita, H. y Vinader-Segura, R. (2011). "El impulso de la industria de los contenidos digitales". CIC Cuadernos de Información y Comunicación, 16, 115-124. Disponible en: http:// revistas.ucm.es/index.php/CIYC/article/view/36990/35799.

Withey, L. et al. (2011). Staining Scholarly Publishing: New Business Models for University Press. Chicago: The Association of American University Presses. Disponible en: http://www.aaupnet. org/images/stories/documents/aaupbusinessmodels2011.pdf. 
La industria de

los contenidos en el sector editorial.

Un caso en la universidad pública

Édgar GARCÍA VALENCIA

Universidad Veracruzana

INTRODUCCIÓN. HACIA DÓNDE VAN LOS CONTENIDOS

1

O es ninguna novedad que el sector editorial se encuentra en cambio constante. Parece que han pasado muchos años, pero sólo era el otoño de 2009 cuando Bob Stein, pionero y gurú del libro digital, fundador del Instituto para el Futuro del Libro, presente en el Foro de Editores de la Feria Internacional del libro de Guadalajara, recibió una pregunta sobre el devenir del libro: ¿cómo imaginaba el futuro uno de los primeros editores en CDROM? Él sólo atinó a responder: "no tengo idea". En los últimos quince años, los cambios han sido tan constantes como imprevisibles, los formatos electrónicos se han diversificado debido en gran parte a la obsolescencia programada de las tecnologías que nos obligan a migrar sistemas operativos (García, Arévalo y Rodero, 2010) y cambiar nuestra información de soportes. Hemos almacenado datos en discos de 51/4 pulgadas, 31/2 pulgadas, ZIP, CDROM, DVD, Blue Ray, USB flash memory, memorias SD y, hasta ahora, la nube. 
Los soportes han favorecido la evolución de formatos electrónicos, que han cambiado también sus propiedades e incluso generado nuevos sistemas de pago que se modifican conforme mutan las posibilidades tecnológicas. Los nuevos modelos de computadoras aparecen de pronto sin unidades de disco, sin ranuras para $\mathrm{CD}$, se van metamorfoseando como si se tratara de una rápida carrera evolutiva.

Un archivo histórico de contenidos en soporte electrónico es involuntariamente también un museo de sus dispositivos. Néstor García Canclini lo vio como resultado de la modificación de la cultura en la sociedad porque: "como revela este nuevo vocabulario, la industrialización de la producción cultural entrelaza a los bienes simbólicos con las innovaciones tecnológicas y con algunas zonas más dinámicas de la economía y las finanzas" (Canclini y Piedras, 2008: 9).

En la edición, el contenido es la esencia. El editor tuvo durante siglos un esquema claro de producción, edición y distribución de sus libros, pero en la última década las Tic han generado un cambio acelerado en la cadena de producción editorial, principalmente porque se han modificado las formas de consumo de contenidos (Palao y Jiménez, 2015). Uno de los campos culturales que se han visto afectados es la edición universitaria, que ha sido permeada profundamente por los nuevos hábitos de consumo y convergencia digital, pero con la característica de generar contenido especializado de alto nivel, especialmente en el surgimiento de la e-ciencia ${ }^{6}$ (Torres Vargas, 2015: 11). Los usuarios llevan la delantera a los editores en la búsqueda de contenidos, pues las necesidades académicas del uso de información hacen que los usuarios hayan acelerado diversas maneras de apropiación y distribución.

6 Se llama así a los trabajos de investigación científica con colaboraciones por medio de Internet en diferentes regiones (Torres Vargas, 2015). 


\begin{tabular}{|l|l|}
\hline \multicolumn{1}{|c|}{ Dominios } & \multicolumn{1}{c|}{ Visitas } \\
\hline ebooks.uv.mx & 236,132 \\
\hline uv.mx & 24,498 \\
\hline m.facebook.com & 6,112 \\
\hline facebook.com & 2,187 \\
\hline catbiblio.uv.mx & 1,070 \\
\hline
\end{tabular}

Tabla 1. De dónde llegan los lectores a la página http://ebooks.uv.mx (periodo del 1 de enero al 31 de diciembre de 2016). Elaboración propia.

Al referirnos a los contenidos, hay que enmarcarlos dentro de las industrias culturales. Ahí se encuentran las industrias de contenido:

Que comprenden la producción pensada para las nuevas tecnologías de la información y comunicación, la convergencia digital y plantean la inclusión social. Es decir, abarcan nuevos modelos de negocio, como los conglomerados multimedia, nuevas estructuras tecnológicas, nuevos lenguajes para esos medios digitales, nuevas maneras de relacionarse con los diferentes públicos y nuevos profesionales capacitados para nuevas demandas, los denominados nuevos intermediarios culturales (Guerra González, 2016: 136).

Acudo a este concepto, relacionado con las industrias culturales, por poner en la mesa esta paradoja: la industria es algo mecánico y automatizable, y la cultura, de naturaleza creativa y única (Piedras, 2013: 66). Pero ¿cómo llevar los contenidos de la edición académica a las Tic? Son las editoriales las intermediarias culturales de esta cadena y deben pensar en las diferentes salidas a su producción. Es la única manera, o por lo menos la más viable, de hacer frente al declive de distribuidores y librerías en México.

Si la lectura sigue siendo una actividad minoritaria respecto a otras de las industrias culturales en México, el segmento 
del libro universitario es tan minoritario como la misma población universitaria en el país, que apenas llega al 3 por ciento respecto a la población total. Acorde con esta cifra, están los porcentajes de libros científico/técnicos y de ciencias sociales que leen los mexicanos, que equivalen, cada uno, al 3 por ciento según la Encuesta nacional de bábitos, prácticas y consumos culturales (Conaculta, 2010).

LOS CONTENIDOS NO SON INMUTABLES.

El Caso de la Universidad VeracruZana

Dentro de las industrias culturales, la del libro tiene una diversidad de opciones para ramificar sus salidas gracias a las TIC: los contenidos no son inmutables. La posibilidad de juntar en un repositorio el artículo publicado, además de los documentos y procesos de la investigación, permite recrear esos contenidos para hacer nuevos, para avanzar en obras derivadas o para nuevos estudios. Existen contenidos que no sólo pueden ser digitales, sino que deben serlo. Algunas cifras de la plataforma de libros digitales de la Universidad Veracruzana (http://ebooks.uv.mx) arrojan que durante 2016, con un año de funcionamiento, los contenidos académicos son los más consultados, principalmente en las ciencias de la salud y ciencias duras, más que la filosofía y la literatura. A pesar de que se cuenta con la obra de escritores de gran renombre como Sergio Galindo o Ernesto Cardenal, por mencionar a dos autores preclaros en la literatura latinoamericana, la literatura ha sido, dentro de la plataforma web universitaria, una minoría. La Universidad Veracruzana surgió hace sesenta años y cultivó, desde sus inicios, un sólido catálogo literario, pero en Internet las obras que se buscan de esa editorial son eminentemente académicas. No 
hay un sólo título literario entre los libros más leídos; algunos ni siquiera han sido consultados.

Los lectores que han llegado a la página de libros digitales de la Universidad Veracruzana buscan información académica en Internet, no lecturas recreativas. Lo importante para los textos académicos es que el contenido esté en digital. La visibilidad no tendría comparación respecto a su correlato en papel. El libro más consultado en la plataforma de Internet, Neurofisiología de la conducta, tuvo cien ejemplares impresos en 2013, y 9 mil lecturas en un año (véase tabla 2). Si puede ser digital, será digital, pero el contenido académico debe ser digital. La competencia para visibilizar un contenido editorial en Internet es brutal. La actividad en la red mundial es enorme. Sólo en un minuto se realizan alrededor de dos millones y medio de con-

\begin{tabular}{|l|c|c|}
\hline \multicolumn{1}{|c|}{ Títulos } & $\begin{array}{c}\text { Lecturas en } \\
\text { línea }\end{array}$ & $\begin{array}{c}\text { Tiraje en } \\
\text { papel }\end{array}$ \\
\hline Neurofisiología de la conducta & 9,081 & 100 \\
\hline Ginecología & 7,503 & 500 \\
\hline Arquitectura básica 2 & 2,095 & 1,000 \\
\hline Líneas de transmisión & 1,848 & 1,000 \\
\hline $\begin{array}{l}\text { A cien años de "Introducción del } \\
\text { narcisismo" (1914-2014) }\end{array}$ & 1,701 & 300 \\
\hline $\begin{array}{l}\text { Diálogos sobre cuencas bosques y agua } \\
\text { en Veracruz: una propuesta metodológica } \\
\text { intercultural }\end{array}$ & 1,667 & 500 \\
\hline $\begin{array}{l}\text { Temas selectos de microbiologia médica e } \\
\text { infectologia }\end{array}$ & 1,371 & 300 \\
\hline Manual de análisis de alimentos & 1,318 & 0 \\
\hline Códices de tierras: los lienzos de Tuxpan & 1,306 & 1,000 \\
\hline Comunicaciones por satélite & 1,063 & 1,000 \\
\hline
\end{tabular}

Tabla 2. Libros más leídos en la plataforma http://ebooks.uv.mx (durante 2016). Elaboración propia. 
sultas en Google (Leboeuf, 2016). No digo ya encontrar, sino saber de la existencia de un libro es ya un milagro si no estamos conectados a las redes adecuadas y si las publicaciones no tienen los metadatos necesarios para ser registrados por los cosechadores de información. Por lo tanto, el contenido académico debe ser digital, pero para ser visible en ese mundo requiere de tener toda la información disponible como metadatos; de lo contrario, será casi invisible en la maraña de información.

ACCESO ABIERTO.

Modelo DE NEGOCIO, MODELO DE DISTRIBUCIÓN

Si algo no podemos dejar de lado al hablar de contenidos académicos, es el acceso abierto. La variedad de modelos de negocio que se tienen para las diversas opciones de distribución de los contenidos permiten que éstos tengan una posibilidad de dirección de acuerdo con la posibilidad de sus canales y la versatilidad de sus soportes. La convergencia digital en los procesos editoriales en los últimos lustros, así como el uso de técnicas digitales para todas las fases de la producción, distribución y consumo del libro, han potenciado la distribución por el acceso abierto (Morales Campos, 2015).

Para hablar del acceso abierto, hay que partir del concepto de cultura libre porque, teóricamente, gran parte del problema radica en las prácticas culturales. Es ahí donde el concepto de cultura libre nos abre una manera de tratar el problema. Nos dice Lawrence Lessig, el creador de esta teoría e ideólogo de Creative Commons: "Una cultura libre no es una cultura sin propiedad, no es una cultura en donde los artistas no son remunerados. Una cultura sin propiedad, en la cual los creadores no puedan ser remunerados, es anarquía, no libertad" (2004: XVI). 
En la edición universitaria, nos encontramos ante distintos tipos de autores, no ante un concepto de autor único. Un caso es la investigación con los datos abiertos, que debería estar tal cual en repositorios, y otro es el libro producto de esa investigación, corregido, legible, resumido, claro, con índices si está impreso, con metadatos si es digital, sin extensos anexos pero con buenas ilustraciones y tablas cuidadas. La investigación no hace un libro, el libro lo hace un editor dentro de una colección con la intención de que dialogue en un catálogo.

Las posibilidades de dar salida parcial o total a esos contenidos, enriquecidos, aumentados, adicionados, aumentan día con día. No está de más pensar que una salida es el acceso abierto, total, parcial o fragmentado. Un texto clásico para la lengua hispánica, por ejemplo, Don Quijote de la Mancha, ha tenido múltiples posibilidades de salida para sus contenidos. Si es en papel, hay ediciones literarias, ilustradas, en rústica o en Cartoné, con tirajes determinados; si es en digital, lo podemos tener como aplicación o como e-book. Como aplicación estaría en una plataforma para determinados sistemas operativos, como recurso multimedia o realidad aumentada; como $e$-book tenemos otras opciones dependiendo del dispositivo, si es para Kindle o como ePub, en texto fijo o líquido, texto plano o interactivo con hipervínculos. Las posibilidades que tenemos se modifican constantemente. Véase simplemente la bibliografía de las ediciones de Don Quijote en los últimos veinte años (Urbina, 2001). La primera vez que Don Quijote se publicó de manera interactiva en CDROM en la edición de Francisco Rico de 1998, el lector tenía la posibilidad de realizar un análisis textual; ordenar por palabra y buscar, por ejemplo, cuáles eran las más usadas en la obra. El contenido se hacía totalmente dúctil, el lector podía deshilar su entramado en las partículas más elementales, sus palabras y analizarlo 
así. Quedarnos con un sólo soporte o una sola y primera edición es tan ocioso como inalcanzable: el contenido se adapta a los nuevos formatos.

Paralelos a esta diversidad de salidas están, además, los clubes de lectura en línea y las redes sociales, que son útiles para fidelizar a los lectores con nuevos contenidos. Las posibilidades y sus combinatorias son ilimitadas, y éstas se conjuntan para lo más importante: permanecer accesibles. "La accesibilidad es lo que organiza al sistema. Ser accesible: no en el sentido de fácil (aunque eso existe y constituye gran parte de los que se publica), sino de estar a la mano. Poder ser extraído del circuito por unas manos ávidas de lectura" (Olcese, 2015: 330).

Ya di el ejemplo de cómo la Universidad Veracruzana tiene muchas posibilidades en acceso abierto: hay títulos de los cuales no se apostaron grandes tirajes que ahora son consultados por miles y que, disponibles en la red, con los metadatos necesarios, circulan la información en los círculos adecuados: se pudo sobrepasar la posible vida útil de algunos contenidos en su distribución en papel. El acceso abierto es una manera inteligente de distribución de contenidos.

La emergencia de nuevos intermediarios culturales (Guerra González, 2016: 136) nos habla de que las editoriales están cambiando desde dentro. No podemos pensar en la estructura editorial de la misma manera que como se había trabajado hasta los últimos años. Dedicar un área exclusivamente a editar en digital, además de ser un lujo que no todos se pueden permitir, implica que todavía hay flujos de trabajo de la vieja guardia. La solución quizá no es incorporar personal, sino la capacitación y el repensar los flujos de trabajo. Éstos ya han mutado. El acceso abierto es un concepto que se ha diseminado gracias a las TIC, su espíritu ya existía desde hace más de mil años: se llamaba biblioteca. 


\section{BiBLIOGRAFÍA}

Canclini, N.G. y E. Piedras (2008). Las industrias culturales y el desarrollo de México. México: Siglo xxi / Flacso.

Conaculta (2015). Encuesta nacional de hábitos, prácticas y consumos culturales. México: Conaculta.

García, J.A.C., J.A. Arévalo y H.M. Rodero (2010). "Los libros electrónicos: la tercera ola de la revolución digital". Anales de Documentación, 13 (0), 53-80.

Guerra González, J.T. (2016). "La producción editorial didáctica de la Universidad Estatal a Distancia de Costa Rica: un diagnóstico a partir del modelo de industrias de contenidos". Investigación Bibliotecológica, 30 (068).

Leboeuf, K. (2016). "2016 Update: What Happens in One Internet Minute?" Disponible el 31 de enero de 2017 en: http:// www.excelacom.com/resources/blog/2016-update-what-happens-in-one-internet-minute.

Lessig, L. (2004). Free Culture: The Nature and Future of Creativity. Nueva York: Penguin

Morales Campos, E. (ed.) (2015). Actores en las redes de infodiversidad y el acceso abierto. México: UnAm.

Olcese, S. (2015). "Circuitos transnacionales de la literatura: Joao Gilberto Noll y el umbral de la convivencia”. Estudios de Literatura Brasileña Contemporanea, 46, 327-342.

Palao, Í. y Jiménez (2015). Observatorio de piratería y hábitos de consumo de contenidos digitales 2015. Madrid: GFK.

Piedras, E. (2013). "Economía creativa y el Homo Telecom". En $L a$ configuración estratégica para las políticas cuturales en México (66-68). Guadalajara: UdeG. 
Colaboración entre la bibliotecología...

Torres Vargas, G.A. (2015). El libro digital universitario. Propuesta de un modelo de negocio. México: unAm.

Urbina, E. (2001). "El Quijote a final de siglo: nuevas prácticas y tendencias editoriales". Iberoamericana, 1 (2), 221-232. 


\title{
Una historia de Memoria
}

\author{
Jaime Ortega Reyna \\ Coordinación de Humanidades
}

UNAM

INTRODUCCIÓN

studiar el producto cultural que son las revistas es una
manera de "ojear" el siglo xx. Su presencia a lo largo y
ancho de la historia cultural es palpable. No hay grupo
cultural, académico o político que no haya pretendido fundar
y mantener una publicación de esta naturaleza. Las revistas
son maneras de llenar huecos que se consideran evidentes,
y también son espacio de socialización y creación de redes.
En términos de revistas políticas, el siglo xx ha visto la apa-
rición de productos tales como Frente a Frente, Futuro, Nueva
Época, Política, Nueva Política, Historia y Sociedad, Coyoa-
cán, Cuadernos Políticos y Dialéctica; algunas de ellas han
sido desde sus inicios estudiadas (Illades, 2012). En América
Latina, son conocidas las referencias a revistas como Amauta,
Los Libros, Sury Pasado y Presente. La lista podría ser intermi-
nable. Lo que sugerimos ahora es acercarnos a una de ellas,
cuya vida ha sido intermitente y que ha estado en medio de
múltiples coyunturas políticas que ha vivido México. 
Conservar la MEMORIA

La revista Memoria es y ha sido una publicación de tipo político y militante, es decir, cuyo objetivo es producir y circular ideas vinculadas con el campo político y que indistintamente llamaremos ahora de izquierda(s); pues dentro de este campo, la revista tenía una poderosa identificación con la tendencia denominada desde hace un siglo como marxista.

Habría posibilidades de distinguir, realizar matices y operaciones teóricas en torno a los conceptos de izquierda y de marxismo; sin embargo, a grandes rasgos podemos decir que ambos significantes, amplios y ambiciosos, rodean el espectro de la búsqueda de la igualdad y la justicia social. En ellos es que se inscribe, desde sus inicios, la publicación de la revista. A ellos debe también gran parte de su producción. Sin los significantes de izquierda y marxismo, la existencia de la revista Memoria no tendría sentido.

Dentro de este amplio campo, Memoria busca intervenir en la vida pública interpelando a un sector de la sociedad, aquél que se identifica con los significantes antes dichos, es decir, no busca convencer a públicos ajenos a esas corrientes, sino incursionar en un público que de entrada se identifica, de alguna u otra manera, con los significantes políticos. Es, al mismo tiempo, un espacio de circulación de ideas, pero sobre todo tiene la alta pretensión de producirlas, pues busca aprender a construir y reproducir un discurso que contribuya a orientar un tipo específico de práctica política. Podemos decir que producir es significar; lo que Memoria busca es contribuir a la conformación de un nuevo sentido común, es decir, colaborar en la generación de un nuevo horizonte conceptual para interpretar las modificaciones a la realidad, y también para intervenir en esas transformaciones aceleradas del mundo moderno. Escribir y leer es un acto productivo, es un acto que genera una nueva concepción 
y que trae herencias previas a nuestro presente para dialogar, construir y problematizar nuestro mundo conceptual, nuestro horizonte de inteligibilidad.

Podemos decir entonces que el proyecto de la revista $\mathrm{Me}$ moria se ubica en un conjunto de coordenadas que la hacen distinta a las revistas "culturales", las académicas y las comerciales. Pretende ser amplia en su público pero éste es limitado en tanto que responde a una concepción de la política: no es una revista para especialistas, su identificación es simbólica e ideológica; tampoco tiene un conjunto de lectores según la edad o el género, sino que más bien apunta lo político con un énfasis en la intervención.

\section{HACER MEMORIA}

Memoria nació en abril de 1983 en un contexto político muy específico: la disolución del Partido Comunista Mexicano (РСм, nacido en 1919) y la fundación del Partido Socialista Unificado de México (psum) (Concheiro, 2006). Aquél fue un contexto que podríamos denominar paradójico: la izquierda adquiría una nueva identidad cuyo eje articulador era la lucha por la democracia (Concheiro, 2013: 266), en tanto que el conjunto de las fuerzas (incluido el partido gobernante) se movía hacia la derecha, es decir, abandonaba el "nacionalismo revolucionario" para pasar directamente al neoliberalismo triunfante. El proceso, por supuesto, no fue sencillo, supuso múltiples resistencias, reordenamientos, cambios en las lealtades ideológicas y políticas. El horizonte paradójico se encuentra en que mientras la izquierda avanzaba más hacia la creación de un nuevo sentido común y ganaba una relativa influencia sobre la sociedad (de la que había carecido con anterioridad) a través de la demanda de 
la democracia como producción de los sectores populares, más se cerraban los espacios de producto política con el arribo de un modelo que expropiaba al Estado y la sociedad sus lugares privilegiados, mientras que los depositaba en el mundo mercantil-capitalista.
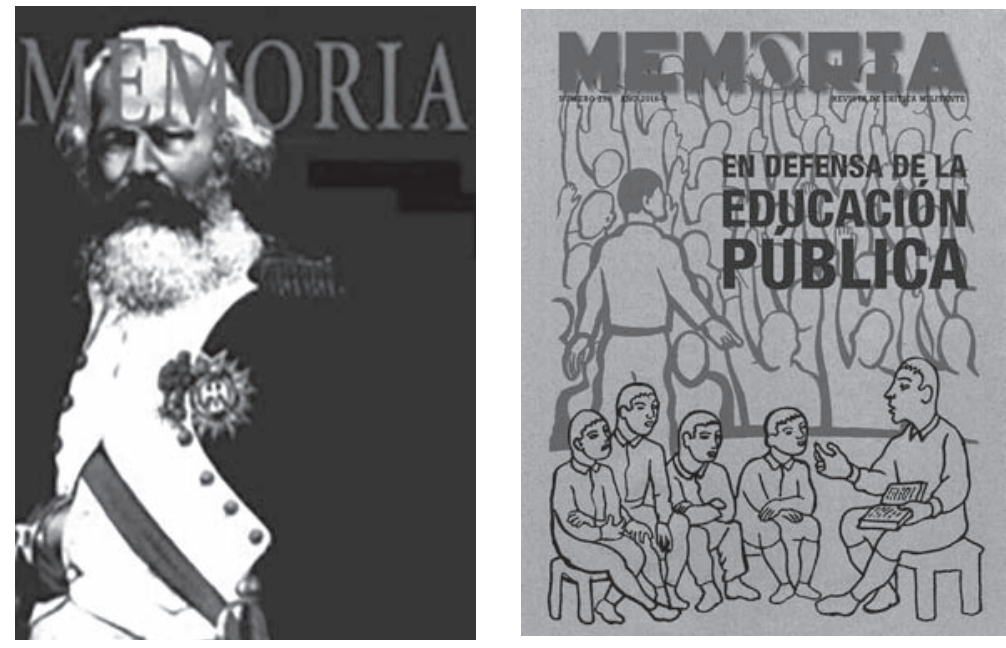

Portadas de la revista Memoria en su primera y segunda época Las imágenes han sido obtenidas del cEMos.

El dominio del mercado, de los poderes "tras las urnas", como los denominó un politólogo italiano, y en general de fuerzas imposibles de controlar por las vías tradicionales, eran apenas los signos de un cambio de época radical. $\mathrm{Na}$ die se encontraba preparado para los cambios y tampoco se sabía cómo afrontarlos; sin embargo, la izquierda política, al menos su sector mayoritario, estaba convencida de que la conquista de la democracia en todos los niveles era la mejor dirección que se podía y debía tomar. 
Memoria apareció en aquel contexto como iniciativa del dirigente comunista Arnoldo Martínez Verdugo, que fundó en el mismo 1983 el Centro de Estudios del Movimiento Obrero Socialista (cEmos). En su origen fue un boletín de aquel centro de estudios y no una revista, y era parte del rescate de una herencia que había nacido en el lejano 1919 con la fundación del Рсм у que había atravesado todo el siglo xx.

La transformación en una revista ocurriró después de veinte ediciones del boletín y siguió así hasta el número 252 en 2013, cuando se cerró una primera y larga época que merecerá tener sus estudios propios. La primera etapa de la revista vio el tránsito del modelo económico y político mexicano, el arribo del neoliberalismo, la transformación de la ideología, la emergencia del cardenismo en 1988 y del zapatismo en 1994; en sus páginas también se presentaron las elecciones del año 2000 y las aún más conflictivas de 2006, así como las huelgas estudiantiles de 1987 y 1999. A partir del año 2015 y del número 253, comenzó una nueva etapa de la revista, pensada para la cotidianidad de la vida política mexicana, las transformaciones a nivel mundial y una reflexión teórica de más largo aliento.

Cabe destacar aquí el lugar que Memoria ocupa en el conjunto de revistas que habían formado parte de la tradición comunista y socialista. Se puede mencionar, por ejemplo, la revista Teoría, que apareció en los años cincuenta y era publicada por el PCM, y por la cual desfilan las contradicciones de la época: el estalinismo, la presencia del Estado mexicano como emisor de una poderosa ideológica nacionalista, los debates internos; poca producción teórica, pero un gran testimonio de una izquierda que ha quedado en la prehistoria.

El verdadero hito de producción y de importancia se dio con la aparición de la revista Historia y Sociedad en 1965, que fue la primera revista impulsada por Arnoldo Martínez 
Verdugo y tuvo su énfasis en la producción teórica e histórica. Ésta fue la primera gran revista de intelectuales marxistas; en diálogo con el mundo académico, incorporó el arte, la historia, la reivindicación de figuras malditas (como Bartolomé de las Casas o José Carlos Mariátegui) y una cantidad de debates de gran trascendencia, todo ello de la mano del reconocido historiador Enrique Semo. Aquella proeza, producida en medio de la represión estatal y de los intentos de renovación, tuvo dos épocas de vida; la segunda concluyó a principios de los años ochenta. Después de ella, siguieron las publicaciones Oposición, Socialismo y El Machete: todas ellas eran signo de renovación, de incorporación de nuevos referentes y del intento de producción de un sentido distinto al seno de las izquierdas: se abrieron espacios para teóricos comunistas como Antonio Gramsci, se tendieron puentes con sujetos sociales que emergían con fuerza, y se apelaba a una cultura mucho más amplia, pues involucraba a sectores populares.

Paralelamente a estas publicaciones auspiciadas directamente desde el PCM, surgieron poco a poco otras que entre la academia y la política plantearon importantes segmentos productivos del pensamiento crítico generado en México: los trotskistas publicaron Coyoacán, una revista que estaba al día de los acontecimientos internacionales; posteriormente, publicaron Viento del Sur, en tanto que el grupo alrededor de la editorial Era publicó Cuadernos Políticos, una revista que navegaba entre la alta erudición teórica y política, y las microcoyunturas. Sin duda, de las revistas mexicanas ésta es la más llamativa por la cantidad de puentes que tendió y por el alto volumen que implicó su intervención en la teoría, aunque a diferencia de otras, planteó con menor fuerza una línea de intervención política inmediata. La filosofía tuvo en la revista Dialéctica, dirigida por Gabriel Vargas Lozano, 
un espacio envidiable de producción y circulación de ideas sobre la doctrina socialista, pues sintetizó lo mejor de la producción latinoamericana, centroeuropea y la de Europa del Este al incorporar al acervo conceptual y teórico las más diversas experiencias. Junto a Memoria, sólo Dialéctica sobrevivió la pesada losa de los años noventa, aquellos del triunfo neoliberal y el derrumbe político del socialismo.

Todas las revistas de las que hemos hablado (y otras, por supuesto) conforman el archivo de la construcción intelectual de la izquierda mexicana. Se trata de un espectro amplio, plural, convencido de la posibilidad de anclar el pensamiento a formas alternativas a las dominantes y de que la intelectualidad tenía algo que decir y formas de decirlo. También, por supuesto, respondía a las necesidades del momento, los discursos en boga y las discusiones a nivel internacional. Ninguna de estas revistas pecó de provincialismo, nunca se miró al ombligo ni fue autocomplaciente; siempre procuraron la apertura, la incorporación de otros discursos, y miraron los bordes del centro imperial de producción, ya fueran hacia América Latina o hacia Europa del Este. México fue un lugar excepcional para la construcción del pensamiento crítico, las revistas que señalamos arriba son un cruce entre una izquierda en busca de una nueva identidad y las tendencias mundiales de renovación de pensamiento.

\section{CONDICIONES DE PRODUCCIÓN}

Tras la caída del Muro de Berlín, la disolución de la Unión Soviética y el triunfo del neoliberalismo como marca de época en la economía y la política, el lugar de una revista identificada con el universo simbólico de la izquierda se vio seriamente modificado. De las revistas antes mencionadas, 
sólo Memoria y Dialéctica se mantuvieron, no sin problemas, como alternativas de producción de pensamiento.

Sin embargo, más allá de la voluntad, existe un hecho innegable: las condiciones políticas, ideológicas y simbólicas habían cambiado radicalmente respecto a la etapa previa. A ello debe sumarse la emergencia de una continua revolución en las fuerzas productivas (en el lenguaje usual identificada como "revolución tecnológica") que ha trastornado la manera de socializar la información.

En menos de veinticinco años, las condiciones han cambiado más rápidamente que en el siglo precedente: la revolución tecnológica ha hecho posible una comunicación más fluida, menos ligada a la materialidad de la producción y ha anclado lo electrónico (y con ello lo visual) como el medio más adecuado para hacer llegar cualquier tipo de mensaje. Estas condiciones han generado nuevas formas de comunicar sustentadas menos en el texto impreso y más en la imagen. A pesar de ello, las revistas siguen existiendo tanto en formatos electrónicos como impresos. A más de uno le asalta la desconfianza ante el imperio de lo efímero que supone la nube electrónica de almacenamiento, constantemente renovada y cuyo riesgo de pérdida es altísimo. Es por ello que la producción de una revista con un sentido político y militante se encuentra atrapada en una pinza: por un lado, el imperio de lo electrónico; por el otro, la importancia que tiene para una cultura política militante la socialización de la opinión.

La izquierda, al menos desde 1903, cuando apareció el opúsculo de Lenin ¿Qué Hacer?, se enganchó en la idea de la centralidad de la publicación impresa. En realidad, esta postura es propia de una cultura política que fue pensada para públicos amplios y no necesariamente letrados sino más bien subalternos, es por ello que en cualquier relato de principios del siglo xx es posible verificar esta coincidencia: 
el papel de la lectura colectiva, de la socialización mano en mano, la preponderancia de la distribución no mercantil; experiencias que igual encontramos entre los anarquistas cubanos, los campesinos revolucionarios mexicanos o los obreros industriales rusos. Lenin, sin embargo, estableció una marca de época para la cultura política de la izquierda: el papel organizador y educador de la opinión impresa.

La revista Memoria forma parte de esa tradición en la que la opinión, el debate y la toma de posición tienden a ser cristalizadas en un medio, en este caso impreso. Sin embargo, aunque deudor de esa tradición, también busca amoldarse a los tiempos. Busca jugar a dos bandas, pensando en que el artefacto impreso es imprescindible, pero también que un mayor impacto se logra en otro lugar.

Las condiciones de producción se encuentran radicalmente transformadas respecto al pasado inmediato. El reto novedoso se encuentra en la combinación y articulación de formas, modos y, sobre todo, en la capacidad de adaptación que permita un mayor impacto, pero también una marca de identidad dentro de la cultura política de la cual la revista y sus integrantes son herederos.

\section{LA CIRCULACIÓN}

El imperio de la circulación es el de aquellos que controlan los espacios que permiten el acceso a los bienes, las mercancías y a lo que Marx categorizó como valores de uso. Es por ello que la circulación de una revista cuyo objetivo es primordialmente político se vuelve una dificultad mayúscula. No sólo porque el público que la consume es restringido (en tanto que interpela a un campo ideológico preciso), sino porque además implica una recomposición de los múltiples 
sentidos de lo que significa ser de izquierda en una época en donde los significantes políticos se han desquiciado radicalmente (no es casual que se cuestionen las nociones de "izquierda-derecha" y se suplanten por "abajo-arriba"). Las certezas del pasado han sido sustituidas por una multiplicidad de toma de posiciones: ello ha vuelto problemático el erosionar fronteras, pero también ha hecho productivo el cuestionar añejas certezas, pues ha permitido diálogos, construcción de puentes y la imperiosa necesidad de pensar de nuevo nuestro mundo, el sentido del programa político, y el lugar de las ideas y de los productores de ideas.

La circulación entonces no puede desprenderse de las condiciones de producción, estas últimas han condicionado de manera radical a las primeras. Menos aun para una revista con las características de Memoria: independiente, sin venta de publicidad, no ligada a una entidad pública. La revista $M e-$ moria es una revista militante no sólo porque tiene un sentido claramente político hacia una dirección, sino porque su hechura y distribución también lo son.

Ediciones MILITANTES

Las nuevas condiciones de producción y distribución, y también las coordenadas políticas e ideológicas, no han impedido la continuidad y emergencia de proyectos similares a Memoria. Además de publicaciones que podríamos denominar como clásicas, como la New Left Review, han aparecido revistas de importancia creciente. Jacobin quizá es la más notable de ellas, ha sido un verdadero hallazgo en la producción en habla inglesa, pues ha convocado a las mejores plumas ubicadas en el ala izquierda del pensamiento, al dar un espacio tanto a reflexiones de coyuntura (por ejemplo las elecciones en Estados Unidos o 
la crisis de la Unión Europea) como a reflexiones teóricas más amplias y menos ajustadas a contextos específicos.

Las revistas de estas características tienen el corazón puesto en un objetivo: realizar una transformación en el horizonte de sentido de la práctica de la izquierda. Si bien su alcance es limitado, su objetivo es necesario. Se trata de pensar continuamente las condiciones sociales y políticas, las transformaciones que se operan desde los poderes económicos y políticos, la emergencia de nuevas formas sociales que buscan hacerse un espacio en la escena pública, y la configuración de fuerzas políticas que forman alianzas antes impensables. Apuestan a un nuevo paradigma, a pensar las viejas preguntas con respuestas nuevas y plantear nuevas interrogantes. Se trata de cristalizar corrientes de pensamiento alternativas, así como desestabilizar los conceptos y las certezas que impiden ver la profundidad de los fenómenos. Podemos arriesgar la hipótesis de que Memoria, con su modesta intervención y junto con otros muchos esfuerzos, tiene por objetivo movilizar la imaginación política: reinventar el pensamiento, las formas de hacer práctica, de relacionarse, de convivir y debatir. Pequeño esfuerzo, pero que será valorado en la medida en que logre convocar a esa imaginación, necesaria e indispensable en tiempos de profunda crisis.

\section{Bibliografía}

Concheiro, E. (2013). "Gramsci en América Latina”. En M. Modonesi (comp.), Horizontes gramscianos (261-276). México: unAM. (2006). "Los comunistas mexicanos: entre la marginalidad y la vanguardia". En E. Concheiro, M. Modonesi y H. Crespo (comp.). El comunismo: otras miradas desde América Latina (527-558). México: СЕICH. Illades, C. (2012). La inteligencia rebelde. México: Océano. 


\section{Políticas de acceso a la información para el desarrollo social y económico}




\title{
Política de acceso a la información para el desarrollo social y económico
}

\author{
EgBert John SÁNChez VANDERKast \\ Instituto de Investigaciones Bibliotecológicas y de la Información \\ UNAM
}

\section{INTRODUCCIÓN}

T a década de los noventa fue trascendental para la información por el auge en el uso de las telecomunicaciones, la incorporación de los medios electrónicos y computacionales para el almacenamiento, y la recuperación de datos e información con miras a brindar un servicio ágil bibliotecario y de información.

Uno de los retos fue atender el constante reclamo de las diversas comunidades para hacer efectivos distintos pronunciamientos como la Declaración de los Derechos Humanos y programas que giran alrededor de la información, concibiéndola como un insumo para el desarrollo. En el ámbito de la bibliotecología, Páez Urdaneta postuló en "La información para el progreso de América Latina" reflexiones que estuvieron basadas en los derechos humanos y los diversos programas relativos a la información auspiciados por la Unesco con el fin de "crear las condiciones necesarias para que la humanidad [...] pueda disponer, usar, generar y preservar la 
información necesaria para su progreso social y cultural" (1990: 5-6). Dicho llamado paulatinamente encontró un eco que sirvió para "fundamentar un conjunto de acciones orientadas hacia la organización y el direccionamiento de los sectores nacionales de información como herramienta del desarrollo social y económico" (6-7), que posteriormente desemboca en lo muy complejo que son las políticas nacionales de información; y lo más evidente es la praxis de la gestión de los recursos básicos de la información.

Mientras que en América Latina se analizaba la información para el desarrollo social, económico y cultural, centrando las reflexiones en las políticas nacionales de información, que deberían "estar orientadas al logro del desarrollo nacional, la reducción de la brecha que separa a los informados y no-informados, al hecho evidente de que la información atraviesa de manera horizontal a todas las actividades del Estado, sean estas culturales, científicas, políticas y sociales; no constituye por lo tanto una política a ejecutar en un periodo determinado de gobierno" (Pájaro Quesada y Betancourt Campos, 2007: 86-93), en otras latitudes la atención estaba siendo puesta en la economía basada en conocimiento para el logro del desarrollo económico en primer lugar, seguido por el social.

De acuerdo con Páez Urdaneta, el desarrollo puede ser comprendido como "un constante incremento en capacidad de agregar valor a los factores de producción, y así llenar el vacío de las necesidades materiales e intelectuales [...] de todos los integrantes de la sociedad" (Páez Urdaneta, 1990: 9). En este sentido, cabe destacar que la información se encuentra presente en múltiples entornos y actividades humanas económicas o culturales, aunque en ocasiones es difícil identificar su influencia y dinamismo entre los sectores económicos, de innovación y desarrollo (I+D) y los productivos 
en general. Esto debido no sólo a la rapidez con la cual se utiliza y se genera dicha información, sino porque las personas involucradas realizan dichas actividades sin plena consciencia de las implicaciones que esto tiene.

Las sociedades que tienen su economía basada en el conocimiento perciben la cooperación como un factor importante. Chang Castillo considera que "la vinculación entre gobierno, universidad y empresas está tomando importancia en el intercambio de conocimiento y por ende de relaciones" (2010: 85). En este orden de ideas, la economía tiene como meta generar riquezas a través de las industrias, y el sector social disfruta de la preventa para proporcionar el bienestar a las comunidades por medio del desarrollo que posteriormente es reflejado en el ciudadano. Por otra parte, el gobierno instrumenta leyes, acuerdos, reglamentos y otras normativas para homologar y hacer efectivos los beneficios para el sector productivo y, como consecuencia, conseguir el desarrollo integral de una sociedad.

Ante este panorama surgen las siguientes interrogantes: ¿Cuál es el papel de la academia en el desarrollo económico y social? y ¿Cómo se configuran las relaciones entre bibliotecología/Academia-Sectorespaulatinamente productivos/ económicos-gobierno en una sociedad con una economía basada en el conocimiento?

\section{LA INFORMACIÓN EN UNA ECONOMÍA} BASADA EN EL CONOCIMIENTO

Los gobiernos de los estados-naciones han sido desde siempre de los mayores consumidores de información; por lo tanto, concuerdo con Cornelius (2010) en que el gobierno es uno de los mayores productores de información y constantemente 
busca el acceso a ésta a través de los distintos sistemas de información, sean éstos bibliotecas, archivos o museos (вам). Por lo general, los gobiernos en gran medida ejercen el control sobre la educación y las telecomunicaciones. Leydesdorff y Etzkowitz (2010) identificaron tres dinámicas latentes en la economía basada en conocimiento y el desarrollo social, que son:

1. El dinamismo de la economía de mercado.

2. La dinámica de la producción del conocimiento.

3. La gobernabilidad de las interfaces en los distintos niveles de estructura del país.

Además, desde "un inicio se partió de la tesis de que la universidad puede incrementar el papel de la innovación en las sociedades con economías basadas en conocimiento" (Leydesdorff y Etzkowitz, 2010: 109). La postura de los autores mencionados hace pertinente reflexionar sobre cómo moldear las relaciones y crear los vínculos necesarios entre academia/instituciones de educación superior/universidades-industrias-gobierno. Por ello, Chang Castillo enfatiza que "las empresas con la cooperación de las universidades han manifestado, que la vinculación entre gobierno, universidad empresa [y] está tomando importancia en el intercambio de conocimiento y por ende de relaciones; lo que propicia un ambiente donde éstas [sic] vinculaciones son consideradas como parte del desarrollo de su país generando nuevo conocimiento" (2010: 86) La economía basada en el conocimiento tiene como aliadas a la academia/IEs/ universidades. La bibliotecología es uno de los sectores académicos, esto debido a que el acceso a la información es sustancial en los tres sectores para la generación de innovación y el desarrollo económico. 


\section{TRIPLE HÉLICE}

La economía basada en conocimiento, es la que interactúan la academia, la industria y el gobierno, ha sido denominada Triple Hélice y ha servido como un parte aguas y una visión que paulatinamente se ha visto fortalecida a partir de los congresos celebrados en Ámsterdam en 1996, y hasta el último sostenido en Heidelberg, Alemania. Este modelo ha sido utilizado como una plataforma para moldear los arreglos y vínculos entre academia, industria y gobierno, y el papel preponderante de las universidades en la transferencia de tecnología y conocimiento.

Esta observación lleva a plantear los sistemas de evolución de la innovación basados en tres distintos momentos:

1. El primero (Triple Hélice I), donde el estado-nación engloba a la industria y la academia y marca las directrices, denominado modelo estático o de Estado.

2. Triple Hélice II, donde cada institución es representada como una esfera con límites bien definidos y sin relaciones, es conocido como modelo laissez-faire.

3. Triple Hélice III, que concentra la infraestructura de conocimiento a través de la intersección entre las esferas mencionadas, lo cual genera normativas diversas, redes de cooperaciones trilaterales y organizaciones híbridas (Leydesdorff y Etzkowitz, 2000: 111-112).

Por tanto, el objetivo de Triple Hélice III debería radicar en un entorno de innovación que consiste en una empresa/ industria derivada de la universidad, las iniciativas trilaterales para el desarrollo de economía basadas en el conocimiento, y las alianzas estratégicas entre las agencias como los laboratorios y los grupos de investigación académicas (idem). Para dichos grupos, la información viene a jugar un rol importante en el desempeño de sus actividades para 
la generación de conocimiento (ciencia y tecnología, y de innovaciones). Por lo anterior, el acceso a la información tiende a ser una piedra angular en los "sistemas nacionales de innovación o sistemas de investigación y/o redes de investigación", como lo denominan Etzkowitz y Leydesdorff (idem), donde participan los flujos de información y conocimiento en las sociedades basadas en este tipo de economía.

Cada red de investigación está centrada por naturaleza en los flujos de información, los controles reflexivos y las características culturales que son los nodos de comunicación, así como las redes y organizaciones que construyen relaciones a través de las iniciativas de sus participantes; organizaciones analistas y hacedoras de política que a su vez establecen estrategias, intenciones y proyectos para crear nuevas dinámicas en las sociedades. Estos dinamismos generan procesos de innovación que deberían de tomar en cuenta otros elementos como la fuerza del mercado y el control institucional. Requieren de acceso a la información y, por qué no, también de una política de acceso a la información. Una política de información en lo que Etzkowitz denomina "la era de la Triple Hélice", que está compuesta por una info-esfera según la concibe Vlahos: "la fusión de las redes de comunicación mundial, las bases de datos y las fuentes de informaciones en el más amplio, entrelazado o heterogéneo para los intercambios electrónicos" (1998: 89). En este contexto, concuerdo con Chang Castillo en que los componentes básicos de un modelo de Triple Hélice lo dotan de las sihuientes caracteristicas:

Supone una mayor importancia en el papel de la universidad en la innovación, a la par con la industria y el gobierno basado en la sociedad del conocimiento. En segundo lugar, hay un movimiento hacia las relaciones de colaboración entre los ámbitos institucionales 
que es cada vez más un resultado de la interacción y no de una propuesta de gobierno. En tercer lugar, además de cumplir con sus funciones tradicionales, cada ámbito institucional también toma el papel de los roles de otro, que operan en un eje de su nuevo, y en otro de su función tradicional. Una universidad empresarial, que toma los papeles tradicionales de la industria y el gobierno, que es la institución central para innovar regiones (2010: 89).

En esta misma sintonía, las instituciones de educación superior deberían de asumir un rol de formadores de empresas y proveedores de personal entrenado y calificado con los conocimientos básicos. Para ello, las actividades de docencia e investigación requieren tanto del acceso a la información como de la disponibilidad de la misma. En este ámbito, quienes son formados para esas labores son los bibliotecólogos.

A su vez, el gobierno tiene que hacerse de información y datos para apoyar a las IEs a través de legislaciones, regulaciones o normativas jurídicas; así como también ofrecer incentivos económicos a las universidades para la gestión de formación de personal y, por otro lado, apoyar por medio de incentivos fiscales a las empresas e industrias. Estos últimos requieren de información para desarrollar y promover avances tecnológicos. Tanto para las IEs como para la industria, el acceso a la información de alto nivel se requiere para generar conocimiento y establecer mecanismos de cooperación,

con el fin de poner en práctica las tecnologías de información y comunicación que contribuyan al desarrollo económico del país, sin perder de vista el desarrollo social que exigen los sistemas de los entornos intra y extra sociales como el Instituto Nacional de Acceso y Transparencia y Protección de los Datos Personales, la Comisión de Derechos Humanos, y las Organizaciones No Gubernamentales. 


\section{ACCESO A LA INFORMACIÓN}

El acceso a la información aunando al modelo de Triple Hélice busca, en primer lugar, aumentar la productividad y el costo beneficio del sector económico y, en segundo, transformar las instituciones estructuralmente a partir de su organización interna. La Triple Hélice, de acuerdo con Etzkowitz y Leydesdorff, persigue los siguientes puntos:

1. El establecimiento de alianzas estratégicas como los tratados comerciales, de cooperación y multilaterales de toda índole. Por ejemplo, los tratados de libre comercio como el tLCAN, el Merco-Sur y el Tras-Pacifico, entre otros.

2. Crear interacciones entre industrias y empresas transnacionales que pueden ser benéficas económicamente hablando.

La Triple Hélice posee una dinámica propia acompañada de poca estabilidad. Al extrapolar esta idea a la bibliotecología, una de las aristas a tomar en cuenta sin lugar a dudas es la misión de la universidad, su papel en el desarrollo económico y en la sociedad. Es sabido que las universidades no sólo son consideradas parte importante del desarrollo de recursos humanos, sino también como un indicador de desarrollo en general, ya que pueden aportar tanto al crecimiento económico como a la transformación de las sociedades a través de la formación de capital humano. La cultura llega a convertirse en uno de los elementos cruciales para el desarrollo de niveles de comunicación y para la conformación de redes y de organizaciones entre los diferentes componentes de los tres grandes elementos de la Triple Hélice. Por ello es determinante el acceso a la información, tanto la transmitida a través de publicaciones periódicas como la contenida en patentes que, como indican Etzkowitz y Leydesdorff (2000), son diferentes sistemas 
de referencias que transforman el conocimiento y la tecnología en productos para el mercado.

En esta línea de ideas, el vínculo entre los sistemas de innovación debe ser entendido como redes de relaciones que generan dinámicas de intención, estrategias y proyectos definidos con expectativas propias. Para ello, el acceso a la información es un elemento clave y concuerdo con Buckland (1991, pp. 78-79) en los siguientes aspectos de dicho acceso:

1. El acceso indicativo o identificar las bibliografías, la documentación, clasificación, recuperación e indización de los ítems son considerados como procesos en dos etapas: seleccionar el instrumento de búsqueda de información e identificar el documento deseado.

2. El acceso físico o disponibilidad del documento, así como su obtención.

3. El pagar un precio: el usuario de la información debe pagar por ella. Éste puede ser uno monetario o el tiempo y esfuerzo en utilizar y sacar provecho de un sistema de información no amigable, que se convierte en una de las barreras para el acceso a la información. 4. El costo del proveedor. Debe ser entendido como los esfuerzos no sólo monetarios, de los espacios y los valores que persiguen las instituciones, sino también como la concepción sobre los servicios de información, que depende en buena parte de la misión y la visión de las instituciones, los valores sociales que persiguen y el rol que juega la institución en la sociedad; por otra parte, hay que considerar los conflictos de valores que varían desde la seguridad nacional, la propiedad intelectual y los intereses comerciales.

5. La aceptabilidad, según la cual el usuario está dispuesto a aceptar una fuente por ser confiable o tener autoridad cognitiva. A partir de ésta, puede surgir una disonancia cognitiva en el momento en el que se forma una "opinión donde hay que adoptar una decisión [...] surge una disonancia entre la cognición de la acción que se 
lleva cabo y las opiniones y conocimiento que señalan una acción diferente" (Ovejero: p. 202). En otras palabras, cuando el usuario recibe nueva información sobre la temática crea una disonancia cognitiva con el conocimiento existente.

6. El acceso cognitivo. El acceso como se ha visto puede ser de tipo indicativo y físico, y también cognitivo. De acuerdo con Buckland, es "entender el contenido del documento", (1991, p. 79) lo cual se busca en la explicación brindada por una persona conocedora de la temática, en una traducción de un texto si éste se encuentra en un idioma que uno no domina y, en el caso de la educación, a través de las fuentes de consulta.

La bibliotecología y el bibliotecólogo actúan como agentes conocedores de los accesos indicativo, físico y cognitivo; de los flujos de información y del ciclo de transferencia de información; además, poseen la capacidad intelectual, las habilidades y competencias para "ayudar a los gobiernos, a las instituciones [e] individuos a transmitir, organizar, estructurar y comprender la información que es importante para el desarrollo" (Declaración de Lyon sobre el acceso a la información y el desarrollo, 2014).

La bibliotecología en marco de la Declaración de Lyon sobre el acceso a la información y el desarrollo de 2014 debe promover acciones generales como las siguientes:

a) Ofrecer información sobre derechos humanos, servicios públicos, medio ambiente, salud, educación, oportunidades laborales y gasto público que apoye a las personas y comunidades locales para orientar su propio desarrollo.

b) Identificar y centrar la atención sobre las necesidades y problemas que sean relevantes y urgentes entre la población.

c) Vincular a las partes interesadas más allá de las barreras regionales, culturales y de otro tipo para facilitar la comunicación y el 
intercambio de soluciones para el desarrollo que puedan adaptarse para conseguir un mayor impacto.

d) Preservar y garantizar el acceso constante del público al patrimonio cultural, a los registros gubernamentales y a la información por medio de la gestión de bibliotecas y archivos nacionales y de otras instituciones del patrimonio público.

e) Proporcionar foros y espacios públicos para una mayor participación y compromiso de la sociedad civil en la toma de decisiones. f) Ofreciendo formación y desarrollo de habilidades que ayuden a las personas a acceder y comprender la información y los servicios que les sean de utilidad (idem).

Esta declaración está dirigida a mejorar la calidad de vida de las personas; sin embargo, coincide con nuestro tema en algunos puntos como ofrecer información sobre aspectos diversos, principalmente gasto público que apoye a las personas $y$ comunidades locales para orientar su propio desarrollo; identificar y centrar la atención sobre las necesidades y los problemas que sean relevantes y urgentes entre la población; y vincular a las partes interesadas más allá de las barreras regionales, culturales y de otro tipo para facilitar la comunicación y el intercambio de soluciones para el desarrollo que puedan adaptarse para conseguir un mayor impacto.

En este sentido, concuerdo con Dijkhuis en que "la innovación no es un bien pre-fabricado, el intercambio de información es una necesidad" (1982: 20). Krupp, por su parte, considera que los vínculos entre las universidades y otras instituciones se puede desarrollar de las siguientes formas:

- Una transferencia de tecnología eficiente que requiere de una comunicación efectiva.

- Eliminar las barreras de interacción cara a cara entre las IES y el sector económico. 
- Considerar que la información y [las acciones y actividades de] la bibliotecología podrían ser necesarias para una comunicación apropiada, aunque no es suficiente (Krupp, 1982: 32).

La bibliotecología y los bibliotecólogos actúan como agentes condicionantes para una comunicación apropiada. Sin embargo, deben incidir en el procesamiento de la información en los bancos de datos y las bibliotecas sin perder de vista la comunicación en todo el proceso de innovación.

Entender la info-esfera de la Triple Hélice permiten a la bibliotecología y sus profesionales diseñar servicios de información para el proceso de toma de decisiones que son:

- Eliminar la duplicidad de trabajos intelectuales.

- Dar nuevas ideas a los científicos y los tecnólogos.

- Sugerir nuevos métodos.

- Conversión de datos en conocimientos (Ljungberg, 1982: 52).

En este mismo sentido, Ljungberg considera que un servicio de información debería de incrementar el proceso de innovación a través de:

- Hacer más corto el proceso de innovación.

- Incrementar la productividad.

- Tener productos de acuerdo al mercado.

- Incrementar la competitividad.

- Tener un mejor medio ambiente.

- Mayor rentabilidad (ibidem: 52-53).

Para ello, el conocimiento de la info-esfera no es lo único que se debería de tomar en cuenta. También tendría que conocerse el proceso de transferencia de información, en particular la fase de reempaquetarla como lo indica 


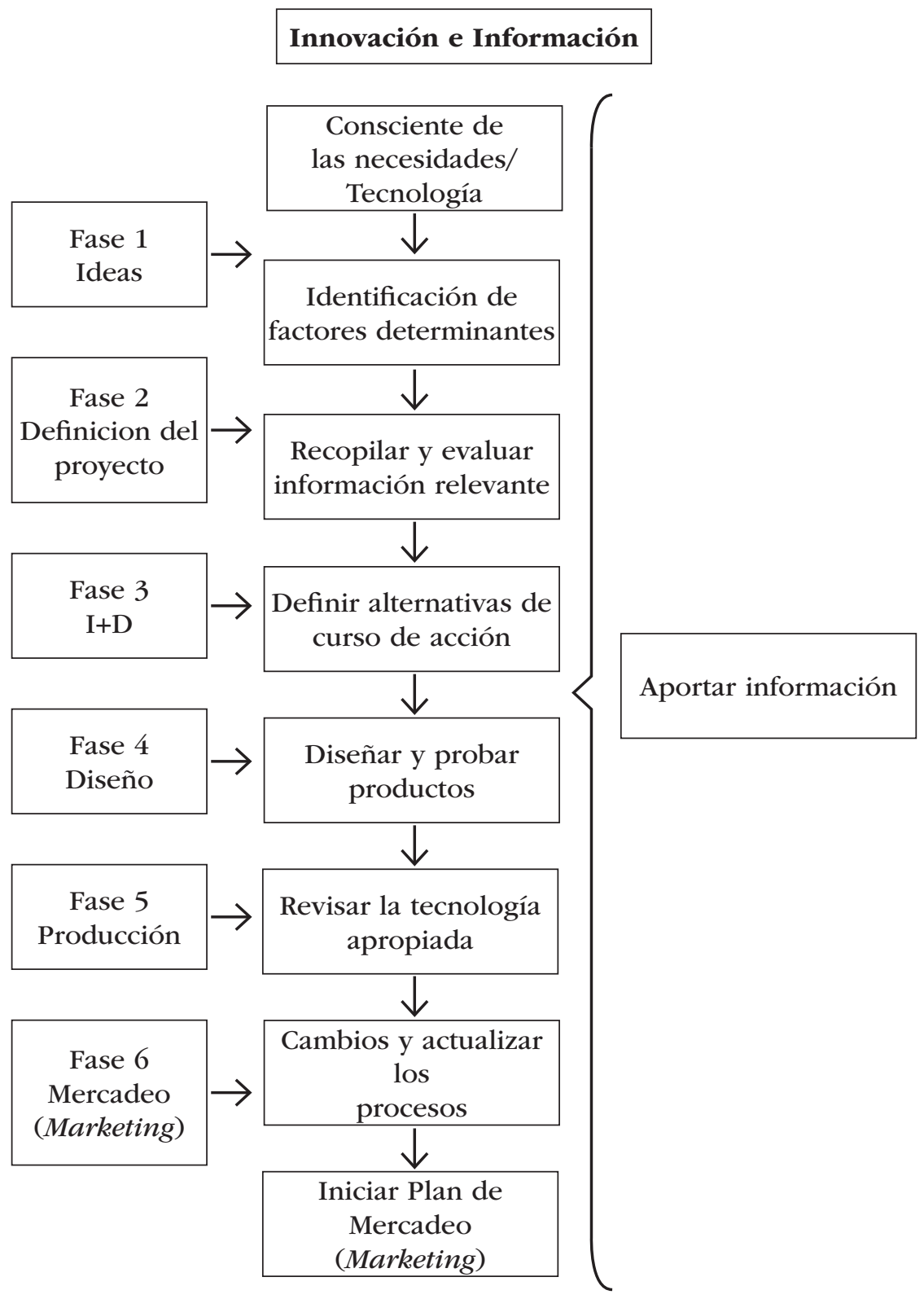

Fuente: Van Houten, R. (1982). 
Browne (1997): Ésta consta de las estrategias de organización (agrupar, clasificar formatear, presentar, visualizar); de síntesis (seleccionar, analizar, interpretar, adaptar y comprimir); de generación de un juicio de valor (presentar los argumentos, empatar las necesidades y problemas, evaluar las ventajas/desventajas, estructurar y compilar), y de toma de decisiones (coincidir con objetivos/las intenciones/los propósitos, comprometer, negociar, seleccionar alternativas y consultar a los expertos) (Ljunbgberg, 1982). El re-empaquetamiento vendría a ser la base para la siguiente fase denominada asimilación por el individuo/usuario experto en esta info-esfera para una toma de decisiones que tiene como resultado acciones y estrategias. Es indispensable que se conozcan los diferentes modelos de procesos de innovación que presentan Du Preez y Louw (2008), y de acuerdo con cada fase de los modelos señalados por ellos, indicar el tipo de información que requiere de apoyo.

Concuerdo con Van Houten (1982) y Eisenschitz (1993) en que cada etapa del proceso de innovación requiere de tipos de información distintos y el bibliotecólogo debería de tener las habilidades y competencias para indagar en los sistemas de información pertinentes.

\section{Conclusiones}

El acceso a la información para el desarrollo social y económico sigue siendo una preocupación de todas las comunidades humanas, sean estos grupos organizados, auto-organizados o familias. Desde el ámbito económico, el modelo de Triple Hélice llega a ser un catalizador de la creación de vínculos entre el gobierno, la academia y las empresas y así puede encaminar a las sociedades hacia una economía basada en conocimiento. 
Este modelo de Triple Hélice basado en la I+D requiere de la información como un insumo crucial en cada una de las fases de los modelos de innovación. Indistintamente del modelo de innovación que elija la empresa, cada fase tiene como pilar la información y, por supuesto, el acceso a la información como factores clave en el sector económico. Los profesionales de la bibliotecología, al tener el conocimiento de los procesos de innovación y de transferencia de información, impulsan la disciplina a un peldaño distinto. El bibliotecólogo, al contar con las habilidades y competencias para brindar acceso indicativo, físico y cognitivo, puede cubrir las solicitudes de cada una de estas fases. La última etapa hace posible en mayor o menor grado el desarrollo social a través de la promoción y difusión de productos que generen una mejora para toda la sociedad. 


\section{Bibliografía}

Benoit, G. y Y. Gingras (2000). "The Place of Universities in the System of Knowledge”. Research Policy, 29, 273-278.

Browne, M. (1997). "The Field of Information Policy: Fundamentals Concepts”. Journal of Information Science, 23 (4), 261-275.

Buckland, M. (1991). Information and Information Systems. Nueva York: Greenwood.

Chang Castillo, H.G. (2010). "El modelo de la Triple Hélice como un medio para la vinculación entre la universidad y empresa". Revista Nacional de Administración, 1 (1), 85-94.

Cornelius, I. (2010). Information Policies and Strategies. Londres: Facet Publishing.

Declaración de Lyon sobre el acceso a la infracción y el desarrollo (2014). Disponible el 24 de enero de 2017 en: http://www. lyondeclaration.org/content/pages/lyon-declaration-es-v2. pdf.

Dijkhuis, W. (1982). "Innovation: Its Evolution and Present State". En B. T. Stern (1982). Information and innovation (3-25). Ámsterdam: North Holland.

Du Preez y L. Louw (2008). A Framework for Managing the Innovation Process. Ciudad del Cabo, Sudáfrica: PICMET.

Eisenschitz, T.S. (1993). Information Transfer Policy. Londres: Library Association.

Etzkowitz, H. (2002). "Networks of Innovation: Science, Technology and Development in the Triple Helix Era”. IJTMSD, 1 (1), 7-20.

Etzkowitz, H. y M. Klofsten (2005). The Innovating Region: Toward a Theory of Knowledge-Based Regional Development. $R \& D$ Management, 35 (3), 243-255.

Etzkowitz, H. y L. Leydesdorff (2000). "The Dynamics of Innovations: from National Systems and 'Mode 2' to a Triple Helix 
University-Industry-Government Relations”. Research Policy, 29, 109-123.

Krupp, H. (1982). "Economic and Societal Consequences of Informatization". En B. T. Stern. Information and Innovation. Pp. (27-47). Ámsterdam: North Holland.

Leydesdorff, L. y H. Etzkowitz (1998). "The Triple Helix as a Model for Innovation Studies". Science and Public Policy, 25 (3), pp. 195-203.

(1996). "Emergence of a Triple Helix of University-Industry-Government Relations". Science and Public Policy, 23 (5), 279286.

Ljungberg, S. (1982). "How Can a Well Organized I\&D Service Help to Improve the Innovation Process in a Company?" En B.T. Stern. Information and Innovation (49-61). Ámsterdam: North Holland.

Ovejero, A. (1993). "La teoría de la disonancia cognitiva". Psicothema, 5 (1), 202.

Páez Urdaneta, I. (1990). Información para el progreso de América Latina. Caracas: Universidad Simón Bolívar/Congreso de la República.

Pájaro Quesada, R. y V. Betancourt Campos. (2007). “QQué es una Política Nacional de Información?” En Hacia la construcción de políticas nacionales de información: la experiencia de América Latina (86-93). Kingston: Unesco-IFAP.

Van Houten, R. (1982). "The Requirements for Specialized Information in an Innovative Process: Research and Technological Applications". En B. T. Stern. Information and Innovation (6385). Ámsterdam: North Holland.

Vlahos, M. (1998). "Entering the Infosphere". Journal of International Affairs, 51, (2), 497- 526. 


\title{
La información y su importancia en procesos políticos, económicos y sociales
}

\author{
Héctor Alejandro Ramos Chávez \\ Instituto de Investigaciones Bibliotecológicas y de la Información \\ UNAM
}

INTRODUCCIÓN

$7 \mathrm{n}$ algunos de los debates más recientes sobre el concepto de ciudadanía, se hace referencia a que para alcanzar niveles amplios de participación social en los asuntos públicos, resulta esencial que los ciudadanos cuenten con información útil, pertinente, suficiente y socialmente relevante, con objeto de que la participación resulte bien fundamentada y coherente con relación a los contextos político, social y económico específicos en los cuales se inserte.

En este sentido, se ha dejado de manifiesto la importancia de contar con políticas públicas eficaces para la obtención y el acceso a la información; muestra de ello han sido los avances normativos que permiten a los ciudadanos acceder a la información pública gubernamental. Con lo anterior, también se refuerzan los procesos de transparencia y rendición de cuentas gubernamentales, con lo que también resulta beneficiada la acción del gobierno. 
Tomando en consideración este contexto, el presente documento está dividido en tres apartados. En el primero, se toma en consideración el tema de la importancia de las políticas de acceso a la información gubernamental, en un contexto en donde la transparencia y la rendición de cuentas son principios insoslayables para la vida democrática de las naciones. En el segundo apartado, se analiza el papel de las políticas de acceso a la información para alcanzar mayores niveles de desarrollo económico, específicamente en comunidades campesinas. Finalmente, en el tercer apartado se toma en consideración la importancia de las políticas de acceso a la información que garanticen el respeto a los derechos humanos de la ciudadanía. Se concluye con algunas observaciones generales.

Políticas de aCCESo A LA INFORMACión GUBERNAMENTAL

Desde hace ya algunos años, han existido tendencias y esfuerzos por parte de muchos gobiernos para apuntalar la consecución de dos principios fundamentales que permiten profundizar en los valores democráticos de las naciones: la transparencia y la rendición de cuentas. En muchos países se han puesto en marcha trabajos encaminados a alcanzar mecanismos de gobierno que le permitan a la sociedad conocer de mejor forma cómo se llevan a cabo los procesos gubernamentales y de gestión pública. En este punto, se ha pasado de una mera enunciación de las actividades llevadas a cabo en el escenario público gubernamental, a un redimensionamiento que apunta a un informe mucho más específico y detallado de la forma en la que se llevan a cabo las actividades públicas, al que se suma el porqué de las decisiones tomadas sobre otras alternativas en el tratamiento de un asunto, así como el cómo y el cuánto en términos presupuestales y de erario público. 
Los temas de la transparencia y la rendición de cuentas no son nuevos, pues existe una amplitud de trabajos tanto académicos como gubernamentales que los han abordado. Un ejemplo de ello es el desarrollo, en la lectura anglosajona, del término accountability (Akutsu y Pinho, 2003; Gray, Owen y Adams, 1996; Przeworski, Stokes y Manin, 1999; Roberts y Scapens, 1985; Seabright, 1996; Sinclair, 1995). Este concepto tiene sus orígenes en la búsqueda por mantener el poder gubernamental bajo control, prevenir los abusos y generar procesos que den certeza del respeto de reglas de conducta en el manejo de los recursos por parte de la administración pública y los funcionarios públicos (Schedler, Diamond y Plattner, 1999). Se llegó a mencionar en la década de los noventa del siglo pasado que el concepto accountability era el término de moda, pues expresaba "la preocupación constante por los controles y la supervisión, la vigilancia y las restricciones institucionales sobre el ejercicio del poder" (Schedler et al., 1999: 13). En términos generales, el concepto de accountability denota una técnica específica para "domesticar" el poder público que abarca tres caminos diferentes para prevenir y coadyuvar a revertir los abusos del poder político y gubernamental. En primer lugar, implica un poder subjetivo aplicable a los ciudadanos consistente en la capacidad o amenaza de sancionar los abusos; en segundo lugar, obliga a los políticos y funcionarios a realizar un ejercicio constante de transparencia; finalmente, obliga a generar justificaciones de los actos realizados (Schedler et al., 1999).

Sin lugar a dudas, existe un estrecho vínculo entre el concepto de accountability y el de rendición de cuentas, éste último mayormente utilizado en la literatura en castellano; sin embargo, existen matices muy importantes que se deben de tomar en consideración y que difieren significativamente 
en ambos conceptos. Quizá la mayor diferencia entre ellos radique en que mientras que el término accountability "conlleva un sentido claro de obligación, la noción de rendición de cuentas parece sugerir que se trata de un acto voluntario, de una concesión generosa del soberano que rinde cuentas por virtud y voluntad propia, no por necesidad" (Schedler, 2004: 10). Esta diferencia resulta esencial, pues dista mucho el reconocimiento, como una obligación, del proceso de transparencia como una suerte de buena voluntad política.

En caso de que el uso del concepto de rendición de cuentas implique una cierta obligatoriedad, su análisis podría surgir en dos dimensiones: "por un lado, la obligación de políticos y funcionarios de informar sobre sus decisiones y de justificarlas en público (answerability). Por otro, incluye la capacidad de sancionar a políticos y funcionarios en caso de que hayan violado sus deberes públicos (enforcement)" (Schedler, 2004: 11). A la par de que estos puntos sirven como dimensiones de análisis académico, también generan un empoderamiento ciudadano en cuanto a la capacidad de vigilar el actuar político y gubernamental y, en determinado caso, su sanción.

Autores como Uvalle (2008: 98) han mencionado que "la transparencia es el camino que permite que el poder no sea inaccesible a los gobernados y es, al mismo tiempo, una fórmula institucional que combina la administración de la información de carácter público (que está a cargo de los cuerpos burocráticos) y la vigencia del derecho a la información que invocan los ciudadanos en las democracias modernas". En esta definición de transparencia, nos damos cuenta del valor fundamental que posee la información en el establecimiento democrático de las naciones, pues se erige como el pilar mediante el cual los ciudadanos pueden poseer herramientas útiles y valiosas para su 
involucramiento en los asuntos públicos, así como en la calidad de su relación e interacción con el gobierno.

Una ciudadanía más participativa en los asuntos que impactan a la sociedad conlleva a la construcción de un modelo de gobernanza, gobernanza que no puede existir sin información que transparente los asuntos públicos y el cómo son tratados por los funcionarios, pues

la transparencia entendida como una política pública, se explica en razón de la gobernanza, porque se relaciona con prácticas horizontales del poder, en las cuales los gobernados tienen el derecho a informarse sobre el comportamiento institucional del Estado. Desde este punto de vista, la transparencia no es sólo una práctica más, sino un derecho muy importante que se relaciona con los nuevos vínculos que se establecen entre el Estado y los ciudadanos (Uvalle, 2008, pp. 98-99).

Desde esta perspectiva, la información que permite un modelo de gobernanza puede generar manifestaciones de poder más amplios para la ciudadanía, no sólo desde una perspectiva de conocimiento, aprobación y/o castigo de las formas en que son atendidos los asuntos y elaboradas las políticas públicas, sino con un rol mucho más participativo en las discusiones sobre el rumbo y las formas de acción gubernamentales.

Con estos antecedentes, podemos ubicar a la información y al acceso a la información pública como elementos insoslayables en los que se pueden edificar los pilares de una sociedad más democrática, en la que la voz de la mayoría tenga un eco en la forma en que la minoría atiende los asuntos públicos y dirige la vida del país. Sin embargo, no podemos sólo circunscribir la importancia de la información en los temas democráticos y político-participativos, 
pues la información es clave en muchos otros temas generales y particulares del desarrollo de las naciones, ejemplo de ello es el papel que juega la información en las discusiones del desarrollo económico, tema que será analizado en el siguiente apartado del documento.

Políticas de ACCESO A LA INFORMACIÓN

PARA EL DESARROLLO ECONÓMICO

Sin lugar a dudas, hay una estrecha relación entre el desarrollo económico y los canales de comunicación y de acceso a la información de los distintos actores involucrados en el entramado económico y socioinstitucional de un sector productivo específico. Dependiendo de la fortaleza del intercambio de información útil, verdadera y relevante entre estos actores, también se verá más o menos fortalecida cada una de las cadenas que se relacionan con el proceso productivo.

Ejemplos de lo anterior han sido ampliamente documentados en los trabajos sobre los distritos industriales (Becattini, 1979, 1990, 2002; Bagnasco, 1977; Marshall, 1890), los clusters (Porter, 2000; Martin, 2001; Markusen, 1996), los sistemas productivos locales (Courlet, 1994; Costa, 1992; Courlet y Pecquer, 1996), y los sistemas agroalimentarios localizados (SIAL) (Muchnik y Sautier, 1998; Correa, Boucher y Requier-Desjardins, 2006; Muchnik, 2009; Muchnik, Sanz y Torres, 2008); trabajos en los que se destaca la importancia de contar en un determinado territorio, y además con interconexiones y relaciones sociales que partan de la confianza y el intercambio de información que mejore los procesos, los productos o la distribución de los mismos.

En los SIAL, por ejemplo, se ha enfatizado en el análisis de los factores sociales que se dan entre los actores de un determinado 
sistema-producto, inclusive se ha llegado a considerar el elemento del capital social como uno fundamental que puede guiar al éxito o fracaso de la producción de un alimento o producto específico (Boucher y Muchnik, 1995; Muchnik, Sanz y Torres, 2008; Torres, 2010, 2013). En este sentido, se destaca en el capital social el elemento de la confianza, que sólo se puede dar si existen relaciones sociales sólidas entre los diversos actores, en las que existan canales veraces y oportunos de comunicación, pero sobre todo de información, que permitan que la toma de decisiones esté racionalizada en un entorno que le proporcione a cada actor seguridad y certeza, así como un conocimiento sobre el sistema en su conjunto.

Los SIAL se intentan diferenciar de otras formas de producción en las que los beneficios y canales de información no son proporcionales ni distribuidos de forma simétrica entre los distintos actores. Ejemplo de lo anterior resultan las formas "caciquiles" o de "coyotaje" en las que comúnmente los productores son los que obtienen menores beneficios de su producción, lo que genera una pauperización de la calidad de vida de los habitantes de las zonas rurales de diversos países, entre ellos México.

En los mismos análisis de los SIAL, se ha incluido recientemente el estudio de un elemento comentado en el apartado anterior de este documento; nos referimos al concepto de gobernanza, modelo que implica canales adecuados de información entre diversos actores con objeto de que tengan la capacidad de interactuar y hacer más horizontal la toma de decisiones. Se ha definido la gobernanza territorial como "un modelo que puede permitir alcanzar mejores niveles de desarrollo de las comunidades campesinas, a la par de que pueda servir como alternativa a la lucha contra la pobreza y las desigualdades a nivel local" (Ramos, 2016: 115). En términos generales, podríamos ubicar la información como un 
elemento transversal que impacta las dimensiones de análisis de la gobernanza territorial. Por lo tanto, la información puede ser entendida

como un factor esencial en la formación de opiniones y conocimientos, por lo que el libre acceso a ella, así como la existencia de correctos canales que permitan los flujos que a su vez generen la interacción de ideas y posturas entre los distintos órdenes de gobierno, y entre estos con los demás actores involucrados en el desarrollo, son temas de nodal importancia para el análisis de la gobernanza, el estudio de los sial y en general en la investigación de los elementos que permitan la gestión de políticas para el desarrollo local (ibidem: 122).

Desde la teoría se han desarrollado conceptos como la inteligencia territorial (Bertacchini et al., 2013; Dumas, Gardère y Bertacchini, 2007; Girardot, 2011; Ormaux, 2006), que enmarca la capacidad de los actores, en un determinado territorio, de actuar con información suficiente para generar conocimiento, y así alcanzar un correcto equilibrio entre la producción y el desgaste de los recursos de uso común. Se han propuesto como fundamentos teóricos del término inteligencia territorial el "desarrollo sostenible como alternativa a una visión puramente económica del desarrollo; la importancia de los territorios como espacio de acción para su comunidad; las ciencias y tecnologías de la información y de la comunicación como vector del desarrollo y como herramientas de construcción de una inteligencia colectiva" (Girardot, 2011: 24). De lo anterior, se puede desprender que la información y los conocimientos que ésta puede generar son vistos como un pilar esencial para alcanzar formas más responsables de producción con un sentido más social, medioambiental y comunitario. 
Un ejemplo que ilustraría lo anterior, situándonos en la realidad mexicana, es el surgimiento de diversos sistemas productivos agroalimentarios en la zona periurbana de la Ciudad de México. Un caso específico es el de la comunidad de Tlalnepantla, Morelos, en donde, teniendo como antecedente la organización de la comunidad relacionada con la producción de avena, se impulsó un proyecto de organización productiva relacionado con el nopal, que hasta el día de hoy representa el producto más importante de comercialización e ingresos de la zona (materializados en la mejora de los datos del ranking del Índice de Desarrollo Humano de la Región).

En este caso, como en muchos otros, queda de manifiesto la importancia de las relaciones sociales sólidas en la constitución de sistemas productivos, en forma de capital social y sustentadas principalmente en bienes intangibles como el de la confianza y el sentido de pertenencia, valores que se relacionan con un equitativo acceso a información socialmente relevante para cada uno de los actores que forman el sistema-producto. Resulta esencial profundizar más en esos mecanismos de acceso a la información que le permiten a los habitantes de un territorio específico alcanzar mayores niveles de desarrollo social y económico. De igual forma, resulta necesario retomar el análisis del acceso a la información como un elemento que permite el respeto a los derechos humanos, tema que será analizado en el siguiente apartado del documento.

LOS DERECHOS HUMANOS

Y LAS POLÍTICAS DE ACCESO A LA INFORMACIÓN

En el análisis de los apartados anteriores, se ha utilizado el concepto de ciudadanía para hacer referencia a la importancia 
de las políticas de acceso a la información, en un primer momento haciendo referencia a la información como elemento que puede generar una mayor y mejor participación ciudadana en los temas de interés público, y posteriormente centrándome en de la importancia de la información en el desarrollo de sistemas productivos. Hasta ahora, en este trabajo, se ha utilizado una definición de ciudadanía más plural, pues no sólo se centra en el reconocimiento de derechos, sino que toma en consideración una dimensión más participativa de los ciudadanos (en términos políticos en la primera parte de este documento, y económicos en la segunda). Sin embargo, para esta parte del documento resulta fundamental retrotraernos y rescatar una de las primeras definiciones que se le ha dado al concepto de ciudadanía, entendiéndola como "el derecho a tener derechos", pues pese a que se considera una definición obsoleta por considerar una postura positiva del ciudadano (Correa y Noé, 1998; Dasí, 2005; Kymlicka y Norman, 1997; Valente, 2000), aún en algunas regiones del mundo no se cumple a cabalidad, por lo que prevalecen diferencias muy marcadas tanto en el tema de acceso a la información, como en la protección de los derechos humanos.

Para el caso específico de México, se encuentra el ejemplo de las comunidades indígenas, comunidades que históricamente se han encontrado en situaciones de vulnerabilidad tan marcada, que inclusive se ha llegado a argumentar que "para los pueblos indígenas, conquistar la plena ciudadanía en su propio país ha sido una carrera de obstáculos" (Stavenhagen, 2011: 87). Estos obstáculos son de carácter económico, social, político y hasta de acceso a información, necesario para defender sus derechos humanos. Lo anterior se enmarca en un esfuerzo político y social que desde hace tiempo ha reconocido la problemática, por lo que se han 
impulsado políticas para la defensa y protección de estas comunidades, yse han generado argumentaciones como las de Stavenhagen en el sentido de que "los indígenas han disfrutado desde hace un siglo los derechos civiles y políticos formales, pero con muchas restricciones en la práctica cotidiana" (2011, p. 96). Tomando en consideración estas problemáticas, se ha argumentado que

a pesar del largo recorrido, en la sociedad mexicana no se ha generado aún consenso sobre la necesidad y manera de regular las cuestiones relacionadas con la información, pues existen profundas divisiones y una enorme confusión sobre esta materia. A lo anterior ha contribuido, al menos en parte, la falta de rigor que ha existido para precisar el contenido y el alcance del derecho a la información (López-Ayllón, 2000: 157-158).

Ante esto, el trabajo bibliotecológico toma un papel fundamental, tanto desde una perspectiva académica para ser incluida en los debates nacionales sobre la temática, como desde el propio quehacer bibliotecológico, pues los conocimientos específicos de los bibliotecólogos y especialistas de la información podrían dar mucha luz para encontrar las mejores formas, herramientas y servicios para regular las cuestiones relacionadas con la información.

Regresando al caso de las comunidades indígenas, el avance legislativo ha quedado de manifiesto, por ejemplo en el artículo $2^{\circ}$ constitucional, que reconoce la composición multicultural del país fincada en las comunidades indígenas, a la par de la capacidad de libre determinación de ellas, así como la obligatoriedad estatal de formular alternativas para alcanzar una igualdad de oportunidades de desarrollo. En este sentido, las políticas del acceso a la información encaminadas a fomentar el respeto de los derechos humanos de estos 
pueblos son una labor fundamental, a la par de ser una tarea en la que diversos actores deben participar en la búsqueda de mejores alternativas que permitan el desarrollo integral de estas comunidades. En estas discusiones, conviene ser reiterativos en ello, el papel de los bibliotecólogos resulta fundamental.

El ejemplo del acceso a la información y el respeto a los derechos humanos de las comunidades indígenas clarifica, la importancia del reconocimiento del acceso a la información como un tema central en las discusiones que apuntan a la necesidad de generar mejores niveles de respeto de los derechos de estas comunidades; sin embargo, no es el único grupo que se encuentra en esta situación. Grupos de ciudadanos como las mujeres, los ancianos, los jóvenes y los niños, suelen ser los grupos con más violaciones a sus derechos humanos; en muchas de esas ocasiones, el problema radica en una falta de información pertinente y adecuada que les permita la defensa de sus derechos. En este sentido, "es necesario reconocer que el debate en torno a la regulación de la información tiene importantes contenidos tecnológicos, políticos, económicos y sociales" (López-Ayllón, 2000: 159). Por lo que para la búsqueda de soluciones se debería de contar con una amplia interacción entre diversos actores que apuntalen a enriquecer el debate y corregir las problemáticas de las brechas para el acceso a la información y para el respeto universal de los derechos humanos.

\section{Conclusiones}

Como se vio en cada uno de los apartados que conforman este documento, la información y el acceso a ella juegan un papel fundamental en diversos aspectos sociales y económicos. La generación de mecanismos y políticas que permitan el 
correcto y oportuno acceso a la información es fundamental para que los ciudadanos puedan, en primer lugar, conocer su situación y las posibilidades de atender sus demandas o problemáticas y, en segundo, tener la capacidad de argumentar sus opiniones para ser escuchados por los gobiernos y considerados en su administración, y con ello generar mecanismos más horizontales en la toma de decisiones públicas.

Por otro lado, el establecimiento de flujos de información entre los diversos actores que intervienen en un proceso político o económico, puede generar ciertos niveles de confianza que redunden en una simplificación de los costes de transacción de los procesos. En este sentido, se podría argumentar que la información va generando confianza que permite la conformación de capital social, así como cohesión entre la sociedad y entre los actores involucrados en un proceso productivo.

Para hacer valer los derechos que como ciudadanos tenemos, y que nos son otorgados por estatutos nacionales e internacionales, es indispensable en un primer momento conocerlos, lo que nuevamente retrotrae la discusión a procesos informativos que permitan conocer los propios derechos, sobre todo a aquellos sectores de la población que históricamente se han encontrado en situaciones de atraso y vulnerabilidad social y económica. Con $^{\circ}$ lo anterior, nos damos cuenta del papel fundamental de la información en distintos procesos políticos, sociales y económicos, por lo cual debe ser un tema esencial en los debates del desarrollo. 


\section{Bibliografía}

Akutsu, L. y J.A. Pinho (2003). "Sociedade da informação, accountability e democracia delegativa: investigação em portais de governo no Brasil". Revista de Administração Pública, 36 (5), 723-746.

Bagnasco, A. (1977). Tre Italie, la problemática territoriales dello sviluppo italiano. Bolonia: Il Mulino.

Becattini, G. (2002). "Del distrito industrial marshalliano a la "teoría del distrito' contemporánea. Una breve reconstrucción crítica”. Investigaciones regionales, (1), 9-35.

(1990). "The Marshallian Industrial District as a Socioeconomic Notion”. En Pyke, Frank et al. (eds.). Industrial districts and Inter-firm Co-Operation in Italy. Génova: International Institute for Labour Studies.

(1979). "Dal settore industriale al distretto industriales. Alcune considerazioni sull'unitá di indagine dell'economia industriale". Rivista di Economia e Politica Industriale, 1.

Bertacchini, Y., P. Maurel, P. Déprez y R. Plant (2013). "Spatial Information \& Communication Arrangements. A Contribution to Territorial Intelligence". Journal of Emerging Trends in Computing and Information Sciences, 4 (1), 19-28.

Boucher, F. y J. Muchnik (1995). Agroindustria rural: recursos técnicos y alimentación. Bib. Orton IICA/CATIE. Disponible en: https://books.google.com.mx/books?hl=es\&lr=\&id=jyAOAQAAIAAJ\&oi=fnd $\& p g=$ PA $7 \& d q=$ Agroindustria + rural, + recursos+t\%C3\%A9cnicos+y+alimentaci $\% \mathrm{C} 3 \% \mathrm{~B} 3$ n\&ots=6stENnoVYF\&sig=w6AaN_GdafKEruiJgKW7fYrIzYM.

Correa, C.A., F. Boucher y D. Requier-Desjardins (2006). “¿Como 'activar' los sistemas agroalimentarios localizados en América Latina? Un análisis comparativo". En Sistemas Agroalimentarios Localizados, memorias del Congreso Internacional ARTE, Agroindustria Rural y Territorio. (17-27). Estado de México: Editorial UAEM. 
Correa, E. y M. Noé (eds.) (1998). Nociones de una ciudadanía que crece. Santiago de Chile: Flacso Chile.

Costa, M.T. (1992). "Cambios en la organización industrial: cooperación local y competitividad internacional”. Panorama general. Economía Industrial, (286), 19-36.

Courlet, C. (1994). Les systemes productifs localisés, de quoi parlet-on?. En C. Courlet y B. Soulage (comps.). Industrie, Territoires et Politiques Publiques. París: Éditions L'Harmattan.

Courlet, C. y B. Pecqueur (1996). "Districts industriels, systemes productifs localisés et développement”. En L. Abdelmaki y C. Courlet. Les Nouvelles Logiques du Développement, (91-102). París: Éditions L'Harmattan.

Dasí, J. (2005). "Nuevas formas de gobernanza para el desarrollo sostenible del espacio relacional”. Ería, 67, 219-235.

Dumas, P., J.P. Gardère e Y. Bertacchini (2007). "Contribution of Socio-technical Systems Theory Concepts to a Framework of Territorial Intelligence" (1-13). Presentado en Huelva Caenti Conference. Disponible en: https://archivesic.ccsd.cnrs.fr/sic_00260338/document.

Girardot, J. J. (2011). "Inteligencia territorial y transición socio-ecológica". Trabajo, Revista Iberoamericana de Relaciones Laborales, $23(0), 15-39$.

Gray, R., D. Owen, D. y C. Adams. (1996). Accounting \& Accountability: Changes and Challenges in Corporate Social and Environmental Reporting. Prentice Hall. Disponible en: http:// eprints.gla.ac.uk/95486/.

Kymlicka, W. y W. Norman (1997). "El retorno del ciudadano. Una revisión de la producción reciente en teoría de la ciudadanía". Ágora, 7, 5-42.

López-Ayllón, S. (2000). "El derecho a la información como derecho fundamental". En J. Carpizo y M. Carbonell (eds.). Derecho a la información y derechos humanos (157-181). Ciudad de México: UNAM. 
Markusen, A. (1996). "Sticky Places in Slippery Space: A Typology of Industrial Districts”. Economic Geography, 73 (3), 293-313.

Marshall, A. (1890). Principles of Economics. Londres: Macmillan.

Martin, R. (2001). A Study on the Factors of Regional Competitiveness, A Draft Final Report for The European Commission Directorate-General Regional Policy. Cambridge: University of Cambridge.

Muchnik, J. (2009). "Localised Agrifood Systems: Concept Development and Diversity of Situations". Ponencia presentada en Annual Meetings of the Agriculture, Food, and Human Values Society and the Association for the Study of Food and Society. Pensilvania, 28-31 de mayo.

Muchnik, J., J. Sanz y G. Torres (2008). "Systèmes agroalimentaires localisés: état des recherches et perspectives”. Cahiers Agricultures, 17 (6), 513-519.

Muchnik, J. y D. Sautier (1998). Systèmes agro-alimentaires localisés et construction de territoires. 46. París: ATP Cirad.

Ormaux, S. (2006). "Methods for Territorial Intelligence". (Vol. 2: 25-27.). Presentado en International Conference of Territorial Intelligence, Aeternitas. Disponible en: https://halshs.archives-ouvertes.fr/halshs-00519796/document.

Porter, M. (2000). "Location, Competition and Economic Development: Local Clusters in a Global Economy". Economic Development Quarterly, 14 (1), 15-34.

Przeworski, A., S. Stokes, S. y B. Manin (eds.) (1999). Democracy, Accountability, and Representation. Cambridge: Cambridge University Press.

Ramos, A. (2016). "Información para la gobernanza y el desarrollo de Sistemas Agroalimentarios Localizados". En G. Torres (ed.). Territorios en movimiento. Sistemas Agroalimentarios Localizados, innovación y gobernanza. (115-134). Ciudad de México: Bonilla Artigas Editores unam. 
Roberts, J. y R. Scapens (1985). "Accounting Systems and Systems of Accountability-Understanding Accounting Practices in their Organisational Contexts". Accounting, Organizations and Society, 10 (4), 443-456. Disponible en: https://doi.org/10.1016/03613682(85)90005-4.

Schedler, A. (2004). ¿Qué es la rendición de cuentas?. Ciudad de México: Instituto Federal de Acceso a la Información Pública.

Schedler, A., L. Diamond y M. Plattner (eds.) (1999). The Self-Restraining State: Power and Accountability in New Democracies. Colorado: Lynne Rienner Publishers.

Seabright, P. (1996). Accountability and Decentralisation in Government: An Incomplete Contracts Model. European Economic Review, 40 (1), 61-89. Disponible en: https://doi.org/10.1016/00142921(95)00055-0.

Sinclair, A. (1995). "The Chameleon of Accountability: Forms and Discourses". Accounting, Organizations and Society, 20 (2), 219-237. Disponible en: https://doi.org/10.1016/0361-3682(93) E0003-Y.

Stavenhagen, R. (2011). "México en el Bicentenario: la ciudadanía indígena a debate". Revista Andaluza de Antropología, (1), 86-98.

Torres, G. (2013). Sistemas agroalimentarios localizados. Innovación y debates desde América Latina. Revista Internacional Interdisciplinar INTERthesis, 10 (2), 68-94.

(2010). "Intensidad de la pobreza alimentaria en las zonas rurales. Localización y nuevas perspectivas para el desarrollo rural. Revista Estudios Agrarios, 16 (44), 47-61.

Uvalle, R. (2008). "Gobernabilidad, transparencia y reconstrucción del Estado”. Revista Mexicana de Ciencias Politicas y Sociales, $L$ (208), 97-116.

Valente, V. (2000). "Una reflexión feminista de la ciudadanía". Estudios feministas, 8 (2), 17. 
Difusión de la información:

experiencias y retos para aportar a la dinamización económica incluyente de los territorios rurales

\author{
R. Antonio Riveros-Cañas y François Boucher \\ IICA-México
}

\title{
INTRODUCCIÓN
}

T a experiencia de los últimos treinta años de trabajo colaborativo entre instituciones de cooperación internacional como el Instituto Interamericano de Cooperación para la Agricultura (IICA), el Centro Internacional de Agricultura Tropical (CIAT), el Centro de Cooperación Internacional en Investigación Agronómica para el Desarrollo (CIRAD) y sus diferentes proyectos ha traído avances conceptuales al conocimiento de las Agroindustrias Rurales (AIR), los Sistemas Agroalimentarios Localizados (sial), la cooperación académica y científica, la formación de capacidades y el desarrollo de herramientas participativas de apoyo a los procesos de tanto de concentraciones de agroindustrias rurales y de desarrollo territorial (Boucher y Reyes, 2011, 2013).

En términos de comunicación, son también importantes los avances logrados a partir de las herramientas de difusión que han sido implementadas a lo largo de estos procesos, y que han contribuido significativamente al alcance de las 
metas y objetivos. Los resultados han permeado hasta las familias rurales y han facilitado el empoderamiento de la información entre ellos.

La comunicación resulta vital para lograr que esta cooperación institucional sea más confiable y respetada, brinde su apoyo de modo más eficiente y contribuya de manera más eficaz a reducir la pobreza y conservar los recursos naturales (IICA, 2016). El caso de las políticas de acceso a la información ha permitido analizar el uso de las redes en respuesta a las problemáticas de los territorios rurales de América Latina y el Caribe.

En estos territorios el 80 por ciento de las explotaciones agrícolas pertenecen a la Agricultura Familiar (AF), que incluye más de sesenta millones de personas y se ha convertido en la principal fuente de empleo rural (Salcedo y Guzmán, 2014). En los territorios rurales, representa más del 75 por ciento de la población, que a su vez tiene altos niveles de marginalización y pobreza que afectan fundamentalmente a mujeres, jóvenes, afrodescendientes e indígenas (IICA, 2014).

En respuesta a esta problemática, el IICA y otras entidades de cooperación promueven una agricultura productiva, competitiva, sustentable y socialmente inclusiva que permita aportar a la reducción de la pobreza procurando el bienestar de sus habitantes. En particular, el IICA impulsa la adaptación de la agricultura al cambio climático al mejorar la utilización de los recursos naturales en la búsqueda de contribuir a la seguridad alimentaria de las Américas (IICA, 2014).

El informe de la CEPAL-FAO e IICA del 2015 sobre las perspectivas de la agricultura y del desarrollo rural en las Américas menciona tres grandes limitantes para su mejora: a) los trabajadores calificados más jóvenes enfrentan escasez de oportunidades de empleo productivo; b) el desajuste de las habilidades o destrezas que se convierten en obsoletas 
debido a los avances tecnológicos en la agricultura; y c) que los jefes de familia mayores dejan las actividades del campo por envejecimiento (CEPAL-FAO-IICA, 2015).

Esta problemática justifica nuevos análisis sobre los pequeños productores y sobre la agricultura familiar que rasalten la importancia de acceder y permanecer en mercados que contribuyan a la seguridad alimentaria. También se buscan alternativas para el alivio de la pobreza rural y la inclusión de ciertos grupos sociales.

Los estudios realizados sobre los procesos de activación de recursos específicos en el marco de los Sistemas Agroalimentarios Localizados (SIAL) han mostrado cómo generar un desarrollo endógeno a partir de las potencialidades de los territorios rurales (Boucher, 2011). También, el estudio de los Sial ha evidenciado que el acceso a mercados dinámicos es uno de los principales frenos del desarrollo económico de los territorios (IICA, 2014). En los últimos años, se ha trabajado en la búsqueda de alternativas para mejorar las condiciones de producción y comercialización en estas areas.

Estas reflexiones tienen como objetivo dar a conocer las formas de acceso y difusión de la información a partir de la experiencia en temas de desarrollo rural y territorial, y responder a la pregunta: ¿cómo se transfiere a los territorios rurales la información generada en los procesos de desarrollo?, además de entender la manera en que las formas de difusión se han vinculado con los avances en la dinamización económica de los territorios rurales.

Este documento se divide en cuatro partes. En la primera, se aborda la importancia de difundir el desarrollo de los territorios rurales con énfasis en la AIR, los SIAL, los procesos de activación de recursos específicos y la dinamización económica de los territorios rurales; la segunda parte comenta las herramientas 
de difusión utilizadas; la tercera reflexiona sobre los impactos generados gracias al uso de las diferentes formas de difusión; y la parte final presenta unas breves conclusiones.

UN TEMA A DIFUNDIR:

EL DESARROLLO DE LOS TERRITORIOS RURALES

En un contexto rural marcado por un mayor dinamismo comercial y por la reducción del rol del Estado, la agroindustria rural enfrenta nuevos desafíos: las nuevas exigencias de los consumidores, la creciente estandarización del modelo de consumo mundial (homogenización de productos alimentarios), los cambios acelerados en los circuitos de distribución y una mayor competencia generada por la importación.

Este entorno resulta más adverso si se agrega la persistencia de altos niveles de marginación y pobreza en las zonas rurales. Una respuesta a esta problemática ha sido el aprovechamiento de las interrelaciones entre la AIR y el territorio, los SIAL, los procesos de activación y los aportes a la dinamización económica de las áreas rurales.

\section{La Agroindustria Rural (air) y}

los Sistemas Agroalimentarios Localizados (sial)

La AIR es entendida como la actividad que permite aumentar y retener, en las zonas rurales, el valor agregado de la producción de las economías campesinas. Esto a través de la ejecución de tareas de poscosecha tales como selección, lavado, clasificación, almacenamiento, conservación, transformación, empaque, transporte y comercialización en los productos provenientes de explotaciones silvo-agropecuarias (Boucher y Riveros, 2000). 
A finales de la década de 1990, los retos de la globalización y la apertura comercial llevaron al límite el modelo de la AIR. Sin embargo, se abrieron nuevas perspectivas para ésta al concentrar geográficamente sus agrupaciones y al aparecer nichos de mercado vinculados a productos tradicionales. Debido a sus características, estas concentraciones de AIR se asimilaron a las nuevas formas de organización descritas como Sistemas Agroalimentarios Localizados (Boucher, 2012).

Los SIAL surgieron como un nuevo modelo de las formas de organización de la AIR. Son definidos como:

Sistemas constituidos por organizaciones de producción y de servicio (unidades agrícolas, empresas agroalimentarias, empresas comerciales, restaurantes, etc.) asociadas, mediante sus características y su funcionamiento a un territorio específico. El medio, los productos, las personas, sus instituciones, su saber-hacer, sus comportamientos alimentarios, sus redes de relaciones, se combinan en un territorio para producir una forma de organización agroalimentaria en una escala espacial dada (Muchnik y Sautier, 1998: 4).

Después de considerar las concentraciones de la AIR como formas de organización tipo SIAL, se iniciaron trabajos para su fortalecimiento mediante los denominados "Procesos de activación de recursos específicos".

\section{ACTIVACIÓN DE RECURSOS ESPECÍFICOS}

Los procesos de activación son definidos como "la capacidad para movilizar de manera colectiva recursos específicos en la perspectiva de mejorar la competitividad de las 
AIR" (Boucher, 2004). En este proceso, las proximidades, las acciones colectivas, las redes de empresas rurales, los procesos de articulación entre territorio, productos y actores, y los saber-hacer locales juegan un papel central.

Un punto importante en los procesos de activación es el impulso a formas alternativas de acceso a nuevos mercados (Boucher, 2015). Dentro de estas alternativas, se considera, por una parte, la conformación de "Canastas territoriales de bienes y servicios", concepto derivado de la noción de canasta de bienes (Pecqueur, 2001), que permite una valorización conjunta de los productos locales articulados a servicios (por ejemplo turísticos). Por otra parte, se toman en cuenta los Circuitos Cortos de Comercialización (ccc) entendidos como una forma de comercio que se fundamenta en la venta directa de productos en los que se reduce al mínimo la intermediación (CEPAL, 2014). En los CCC, prevalece la proximidad y los intermediarios son eliminados o representan una intermediación muy corta entre productores y consumidores (RIMISP-INDAP, 2015).

DiNAMIZACIÓN ECONÓMICA DE LOS TERRITORIOS RURALES

La dinamización económica de los territorios rurales es un concepto en construcción. Los elementos que la definen están ligados a las acciones que permiten agilizar, activar y fortalecer los procesos de desarrollo económico de los territorios.

Los avances en el entendimiento de esta dinamización cuentan con conceptos traídos de la economía industrial (distritos industriales y clusters), la economía territorial, las teorías de la acción colectiva y de las proximidades, y la gestión empresarial. 
El enfoque sial es un elemento fundamental de la noción de dinamización económica por sus aportes al conocimiento de los procesos de activación tanto a nivel de las concentraciones de agroindustrias como al de la gestión del desarrollo de los territorios rurales.

LAS HERRAMIENTAS PARA LA DIFUSIÓN

Y COMUNICACIÓN EN EL DESARROLLO DE

LOS TERRITORIOS RURALES

Las herramientas de difusión de la información han sido fundamentales para el desarrollo de los territorios rurales. La experiencia de los últimos treinta años de trabajo colaborativo ha traído avances significativos en la conformación de redes y programas de cooperación, desde el año de 1983, con la Red Tecnológica Apropiada al Desarrollo Agroindustrial Rural (RETADAR), hasta los avances en la conformación de la Red SIAL-México con productos destacados que permiten dar a conocer la articulación entre los procesos de desarrollo y la difusión (ver cuadro 1).

Los aportes de la AIR y los SIAL, vistos como un sistema, atraviesan el territorio y las cadenas locales facilitando la articulación de los recursos y contribuyendo al desarrollo de los territorios rurales. Desde la década de los ochenta, se inició el trabajo con el Programa Cooperativo de Desarrollo Agroindustrial Rural (PRODAR) y las redes de los países participantes con aportes al fortalecimiento de capacidades científicas y técnicas en los territorios de América Latina y el Caribe (IICA, 1999). En el año 2015, los esfuerzos se centraron en los aportes a la dinamización económica de los territorios (Boucher y Riveros, 2016). A continuación, se presentan algunos de los aportes más significativos de los últimos treinta años. 


\begin{tabular}{|c|c|c|}
\hline $\begin{array}{l}\text { Año de } \\
\text { creación }\end{array}$ & $\begin{array}{c}\text { Redes y } \\
\text { Programas }\end{array}$ & $\begin{array}{l}\text { Productos } \\
\text { destacados }\end{array}$ \\
\hline 1983 & $\begin{array}{l}\text { Red Tecnológica } \\
\text { Apropiada } \\
\text { al Desarrollo } \\
\text { Agroindustrial Rural } \\
\text { (RETADAR) }\end{array}$ & $\begin{array}{l}\text { Boletín impreso } \\
\text { Seminarios anuales } \\
\text { Talleres y capacitaciones } \\
\text { Espacios rurales para } \\
\text { tecnólogos (ERTEC) } \\
\text { Redes electrónicas (con la } \\
\text { aparición de Bitnet) }\end{array}$ \\
\hline 1989 & $\begin{array}{l}\text { Programa de } \\
\text { Desarrollo de la } \\
\text { Agroindustria Rural } \\
\text { para América Latina y } \\
\text { el Caribe (PRODAR) }\end{array}$ & $\begin{array}{l}15 \text { redes nacionales de AIR } \\
\text { Seminarios, capacitaciones, } \\
\text { talleres y cursos } \\
\text { Programa Foodlinks: se } \\
\text { identifican } 200 \text { productos } \\
\text { promisorios obtenidos con } \\
\text { tecnologías que respetan el } \\
\text { medio ambiente } \\
\text { Visualización de la articulación } \\
\text { entre AIR mediante redes } \\
\text { empresariales locales a través } \\
\text { de SIAL }\end{array}$ \\
\hline 2005 & $\begin{array}{l}\text { Agroindustrias rurales } \\
\text { (AIR) }\end{array}$ & $\begin{array}{l}\text { Redes de agroindustrias } \\
\text { rurales en varios países de } \\
\text { América Latina y el Caribe }\end{array}$ \\
\hline 2009 & $\begin{array}{l}\text { Sistemas } \\
\text { Agroalimentarios } \\
\text { Localizados } \\
\text { (SIAL) }\end{array}$ & $\begin{array}{l}\text { Red SIAL México-Europa } 2009 \\
\text { Red SIAL México } 2012 \\
\text { Articulación con Red SIAL } \\
\text { Americana y Red SIAL } \\
\text { Europea. }\end{array}$ \\
\hline
\end{tabular}

Cuadro 1. Redes y programas para el desarrollo de los territorios rurales y productos destacados.

Elaboración propia. 


\section{Aportes AL CONOCIMIENTO}

Los aportes al conocimiento se han hecho en el estudio de las AR, el paso a los SIAL y, posteriormente, en la articulación con procesos de comercialización y gestión de proyectos participativos e incluyentes. Esto a partir de la publicación impresa y digital de artículos, libros, capítulos de libros y estudios de casos. Por ejemplo, la experiencia de las queserías rurales (Boucher y Brun, 2011) y la participación en seminarios y congresos nacionales e internacionales.

\section{CONFORMACIÓN Y DINAMIZACIÓN}

DE REDES Y FOROS CIENTÍFICOS Y TÉCNICOS

Se han creado y promovido redes temáticas de varios niveles SIAL en distintas naciones (Argentina, México, Venezuela y Brasil) articuladas a la red SIAL americana y europea.

FORMACIÓN DE CAPACIDADES

Los avances en la formación se han dado en distintos niveles. Desde el inicio, en los años ochenta, se dieron con los cursos de capacitación Espacio Rural para Tecnólogos (ERTEC). Posteriormente, se promovieron con el paquete de capacitaciones del PRODAR; la formación a nivel de posgrado (doctorantes y maestrantes); la creación y puesta en marcha de la maestría en Agroindustria Rural, Desarrollo Territorial y Turismo Agroalimentario impartida por la Universidad Autónoma del Estado de México; la realización de cursos técnicos en la selva Lacandona para comunidades indígenas de México; y con el diplomado virtual sobre dinamización económica de los territorios rurales con enfoque SIAL en colaboración con el Centro de Cooperación Regional para 
la Educación de Adultos en América Latina y el Caribe (CREFAL). Asimismo, se han impartido cursos presenciales y a distancia, y capacitaciones a nivel técnico a líderes y familias campesinas.

ElABORACIÓN DE METODOLOGÍAS

Se han realizado dos guías impresas y una digital para apoyar los procesos de activación SIAL. La primera, titulada Guía metodológica para la activación de Sistemas Agroalimentarios Localizados (Boucher y Reyes, 2013), fue elaborada como instrumento de acompañamiento para el desarrollo de concentraciones de Agroindustrias Rurales bajo el enfoque sial (denominada como Ruta 1).

La segunda, titulada Guía metodológica para la Activación Territorial con enfoque de Sistemas Agroalimentarios Localizados (AT-SIAL) fue concebida para respaldar la Gestión Territorial mediante la articulación horizontal y vertical de actores de distintas concentraciones de Agroindustrias Rurales y otros agentes en un territorio específico (denominada como Ruta 2).

La guía metodológica digital SIAL es un instrumento dinámico diseñado para apoyar los procesos de activación de recursos específicos en dos niveles: 1 . Concentraciones de AIR. 2. Territorial. En esta guía digital, estos dos niveles están identificados como rutas ( 1 y 2 ) que integran las dos primeras guías metodológicas impresas (Boucher y Reyes, 2011, 2013).

USO DE TECNOLOGÍAS DE LA INFORMACIÓN

Como parte del uso de las tecnologías de la información, se han promovido las redes sociales, las plataformas de información, las capacitaciones a distancia y las listas de correos electrónicos para difusión de la información generada. 


\section{LOS IMPACTOS GENERADOS}

Para responder a la pregunta inicial sobre cómo se transfiere la información generada en los procesos de desarrollo a los territorios rurales, los avances de los últimos treinta años han demostrado una apuesta general por el uso de las redes de colaboración en distintos niveles. A partir de éstas, ha sido posible avanzar de forma significativa en la construcción de institucionalidad, como es el caso de la activación de recursos específicos logrado en la experiencia de las concentraciones de queserías rurales de Cajamarca, Perú (Boucher, 2004).Por otra parte, la difusión de la información ha sido determinante para contribuir a una dinamización económica. A continuación, se presentan algunos de los impactos generados en los últimos treinta años que en gran medida han sido posibles gracias a estrategias decididas de información y comunicación.

Primero, se ha avanzado en el mejoramiento de las condiciones de vida de las comunidades rurales en América Latina y el Caribe gracias a la promoción de la articulación de diferentes actores. Por una parte, con el fortalecimiento de las organizaciones de productores y los grupos de Agroindustrias Rurales que despiertan entre los diferentes actores un espíritu de cooperación-competencia; por otro lado, con el uso de estrategias de comercialización como los circuitos cortos que permiten la proximidad entre productores y consumidores.

Segundo, se ha avanzado en los procesos de dinamización económica al fortalecer el capital social con el aporte de confianza y sentido de pertenencia al patrimonio del territorio. Se han fortalecido también las capacidades de los pequeños productores, quienes a lo largo de estas experiencias han participado activamente en el desarrollo de sus territorios rurales. 
Tercero, a partir de los procesos de activación de recursos específicos se han fomentado la conservación y el mejoramiento de los "saber-hacer" locales (caso de las queserías rurales de Cajamarca y la red de agroindustrias rurales de la selva Lacandona en México) para impulsar la productividad principalmente en los territorios aislados y/o marginados.

Cuarto, a partir de los distintos proyectos de cooperación se ha contribuido a la integración de la agricultura familiar en las dinámicas de desarrollo con proyectos que han abierto espacio a nuevos nichos de mercado para sus productos.

\section{Conclusiones}

Para aportar al desarrollo de los territorios rurales, desde los años ochenta se han usado y aprovechado las herramientas tecnológicas existentes para publicaciones impresas y digitales, se han creado redes y grupos científicos y técnicos, y se han utilizado las redes sociales para difundir la información generada.

Una política clara para la difusión de la información permite la articulación de los procesos técnicos y científicos. El IICA ha mostrado interés en el uso de nuevas tecnologías y en la comunicación mediante plataformas virtuales, que facilitan la cooperación para el fortalecimiento de capacidades en América Latina y el Caribe.

Es imperativo promover la difusión de la información, la investigación científica y la cooperación técnica a distintos niveles para relacionar los sistemas agroalimentarios localizados con las nuevas formas de comercialización (como ejemplo los circuitos cortos) en la búsqueda de nuevas alternativas que aporten a la inclusión de los territorios rurales, principalmente en poblaciones aisladas y en muchos casos excluidas. 


\section{Bibliografía}

Boucher, F. (2015). "Nuevas tendencias y perspectivas de la agroindustria centroamericana". Ponencia presentada en el V Foro Centroamericano de Agroindustria. Octubre de 2015, Santiago de Veraguas, Panamá.

(2012). "De la AIr a los SIAL: reflexiones, retos y desafíos en América Latina”. Agroalimentaria, 18 (34): 79-90.

(2011). "Reflexiones en torno al enfoque siat: evolución y avances desde la agroindustria rural (AIR) hasta los sistemas agroalimentarios localizados (sial)". En G. Torres y R.M. Larroa (coords.). Sistemas Agroalimentarios Localizados en México. Identidad territorial, construcción de capital social e instituciones. México: Juan Pablos Editores.

(2004). Enjeux et difficulté d'une stratégie collective d'activation des concentrations d'Agro-Industries Rurales, le cas des fromageries rurales de Cajamarca, Pérou. Tesis de doctorado. Universidad de Versailles Saint Quentin en Yvelines.

Boucher, F. y V. Brun (eds.) (2011). De la leche al queso: queserías rurales en América Latina. México: Miguel Ángel Porrúa.

Boucher, F. y R.A. Riveros (2016). "Inclusive and Dynamic Economic Growth in Rural Areas: Alternatives from SYAL and Short Chains". Challenges for the New Rurality in a Changing World. Conferencia impartida en Estocolmo, Suecia.

Boucher, F. y J.A. Reyes González (2013). Guía de Activación Territorial con enfoque de Sistemas Agroalimentarios Localizados (SIAL). México: IICA-CIRAD.

(2011). Guía para la Activación de Sistemas Agroalimentarios Localizados (SIAL). México: IICA-CIRAD.

Boucher, F. y H. Riveros (2000). Agroindustria y Agroindustria Rural. Elementos conceptuales y de reflexión. Serie de documentos de trabajo PRODAR, número 12. Lima: IICA-PRODAR. 
CEPAL (2014). Agricultura familiar y circuitos cortos: Nuevos esquemas de producción, de comercialización y de nutrición. Memoria del Seminario sobre Circuitos Cortos. Santiago: CEPAL.

CEPAL-FAO-IICA (2015). Perspectivas de la agricultura y del desarrollo rural en las Américas: una mirada hacia América Latina y el Caribe 2015-2016. San José, Costa Rica: CEPAL/FAO/IICA.

IICA (2016). Política de comunicaciones. Documento interno de trabajo. San José, Costa Rica.

(2014). Proyecto Insignia: Inclusión en la Agricultura y en los territorios rurales. Documento interno de trabajo. San José, Costa Rica.

(1999). Programa de desarrollo de la agroindustria Rural para América Latina y el Caribe. Revista Conmemorativa por el $\mathrm{X}$ Aniversario de PRODAR. IICA/CIRAD/CIID/CIAT.

Muchnik, J. y D. Sautier (1998). Systèmes agro-alimentaires localisés et construction de territoires. Proposition d'action thématique programmée. París: CIRAD.

Pecqueur, B. (2001). "Qualité et développement territorial: l'hypothèse du panier de biens et de services territorialisés. Économie Rurale, 261, 37-49.

RIMISP-INDAP (2015). Cómo vender en circuitos cortos. Desafíos y oportunidades para la agricultura familiar campesina. Serie Manuales y Cursos, número. 4. Chile: Centro Latinoamericano para el Desarrollo Rural, Ministerio de Agricultura.

Salcedo, S. y L. Guzmán (2014). Agricultura familiar en América Latina y el Caribe: Recomendaciones de política. Santiago de Chile: FAO. 


\section{Recursos y servicios de información analógicos y digitales para los consumidores}




\title{
Recursos de información analógicos y digitales para los consumidores
}

\author{
Brenda Cabral Vargas \\ Instituto de Investigaciones Bibliotecológicas y de la Información \\ UNAM
}

\section{INTRODUCCIÓN}

7 valor de la información dentro de esta Sociedad de la 4 Información no puede ser cuestionado debido a que es un factor determinante en los avances científicos y culturales de las sociedades actuales.

Esto se ve constatado en el papel que le dan dentro del Plan Nacional de Desarrollo 2013-2018 de México al conocimiento y la información como pilares para propiciar el desarrollo científico, tecnológico y, por ende, el progreso económico y social sostenible de nuestro país. Este objetivo, desarrollado ampliamente en el Programa Especial de Ciencia, Tecnología e Innovación, hace especial hincapié en la tendencia mundial de conectar a los grupos de investigación con los intereses comunes para la resolución de problemas nacionales prioritarios. 
Los recursos y servicios de información tanto analógicos como digitales son importantes para el desarrollo de cualquier actividad diaria en el mundo actual; sin embargo, en últimas fechas han ido prevaleciendo los recursos digitales en todos los ámbitos y las bibliotecas no han quedado exentas del impacto de lo digital en sus actividades cotidianas. Prueba de ello, como bien menciona Mejía (2016), son los avances en los sistemas de automatización para bibliotecas, la prestación de servicios en línea, la conformación de colecciones electrónicas, la realización de transacciones en tiempo real y la oferta de una amplia gama de recursos de información ofrecidos en red. Asimismo, las reglas, formatos y demás estándares bibliográficos incluyen aportes sobre la administración de la información electrónica y los servicios digitales.

Por otra parte, también se tiene que echar una mirada a los usuarios, los cuales están cada vez más familiarizados con el uso de las tecnologías y reclaman a las organizaciones la opción de acceder a la información en forma remota, de modo que se han convertido en la masa crítica que impulsa y exige servicios en línea de calidad.

Esta situación, aunada al crecimiento de la demanda, la aparición de la modalidad a distancia en la educación y el incremento de aplicaciones de sistemas y software para apuntalar los programas educativos presenciales, obligó a las bibliotecas en general a repensar la prestación de sus servicios y el tipo de recursos de información digital a incluir para sus usuarios. Se ha hecho énfasis en los recursos y servicios de información analógicos y digitales para los consumidores, pues vemos al consumidor como un elemento primordial entre la información y el factor económico, y nos preguntamos cómo éste se enfrenta a la información para satisfacer sus necesidades de información. 
¿LA INFORMACIÓN Y LOS CONSUMIDORES VAN DE LA MANO?

Las necesidades de información están muy relacionadas con las necesidades del consumidor debido a que el término de comportamiento del consumidor refiere al conjunto de actividades que lleva a cabo una persona o una organización desde que tiene una necesidad hasta el momento en que efectúa la compra y usa, posteriormente, el producto. El estudio de tal comportamiento incluye también el análisis de todos los factores que influyen en las acciones realizadas. Las actividades de buscar, comprar, usar y disponer de los bienes para satisfacer las necesidades y deseos, comprenden tanto procesos mentales y emocionales como acciones físicas. Aquí la información es necesaria debido a que entre más información tenga el consumidor, mejores compras podrá realizar, y podrá usar y disponer de los bienes de una forma más adecuada.

A continuación se demuestra de qué manera el conocimiento de las necesidades del consumidor, así como del proceso de decisión y de los factores que lo condicionan, beneficia a ambas partes de la relación de intercambio.

Se sabe que siempre que el usuario realiza una consulta previa a su compra, ésta es realizada de manera más efectiva debido a que se obtienen muchos beneficios para el consumidor. Algunos de esos beneficios son:

- Facilita, orienta y hace más satisfactoria la compra y el consumo de los productos. Si los productos se adaptan a sus necesidades y los precios fijados son los que está dispuesto a pagar, el consumidor se sentirá más satisfecho.

- Si además se conoce el proceso de decisión de compra y los factores que lo influyen, se podrán distribuir y promocionar los productos de forma que la decisión sea más fácil y agradable para el comprador. 
También existen diversos beneficios para las empresas que se informan y que documentan sus procesos antes de lanzar un producto, así como para los que llevan a cabo la planeación de algún aspecto o departamento dentro de la propia institución; algunos de éstos son:

- El desarrollo de una estrategia comercial más adaptada al consumidor hará incrementar la demanda de los productos ofrecidos, lo que aumentará la participación en el mercado y los beneficios de la empresa.

- El conocimiento de las necesidades del consumidor o usuario es el punto de partida para el diseño de la estrategia comercial. Una vez determinadas las necesidades, debe identificarse en qué medida éstas se dan en los distintos segmentos del mercado a los que se van a atender. A continuación, deben posicionarse los productos para satisfacer tales necesidades y desarrollarse estrategias comerciales que comuniquen y suministren los beneficios del producto.

Explicar por qué se considera que los empresarios y los consumidores deben poner un gran interés en mantenerse informados acerca de todo lo que se genera a su alrededor podría parecer ocioso, pero no es así; es necesario sensibilizar a los consumidores en general, debido a que nadie gasta el dinero de otra persona tan cuidadosamente como gasta el suyo. Milton Friedman, economista estadounidense de origen húngaro, dijo en alguna ocasión que "Nadie usa los recursos de otra persona con tanto cuidado como utiliza los suyos. Así que si quieres la eficiencia y la eficacia, si desea que el conocimiento sea utilizado apropiadamente, usted tiene que hacerlo a través de los medios de propiedad privada" (2000).

La información dentro de los sectores económicos y productivos además permite llegar a la innovación y la competitividad, por lo cual podemos afirmar que "La innovación y el 
conocimiento son fundamentales en la competitividad económica porque influyen directamente en las empresas, y porque tienen además un fuerte impacto en la futura dirección de los cambios sociales y económicos" (Pérez, Camacho y Arroyo, 2013). Y esto favorece al consumidor.

El enfoque llamado "visión de la empresa basada en el conocimiento" parte de la teoría de recursos y capacidades, y de la perspectiva de la economía evolutiva. Sostiene que los recursos basados en el conocimiento pueden resultar importantes para lograr una ventaja competitiva sostenida (Pérez, Camacho y Arroyo, 2013).

Estos autores, y otros como Wolfe (1994) y como Becheikh, Landry y Amara (2005), explican que las lagunas existentes en las investigaciones acerca de la relación entre la innovación-imitación y el conocimiento se disminuirían de forma notable si se tuvieran en cuenta tres elementos:

1. La innovación es primordial como un proceso que pasa por múltiples fases, y las variables independientes (causales) deben ser, por lo tanto, diferentes en cada una de ellas.

2. Cada una de las innovaciones va dirigida a un objetivo muy particular que se materializa en diferentes tipos y formas, y las relaciones causales deben ser estudiadas tomando en cuenta cada objetivo particular.

3. Es muy importante el contexto donde se desarrolla cada innovación, así como las fases a través de las que ésta evoluciona.

Al enumerar cada uno de los dos casos presentados en esta mesa, se pudo constatar que los problemas, así como la forma en que se aborda el uso de la información y los recursos informativos con la finalidad de tomar decisiones en el consumo de productos, son diferentes en cada circunstancia; algunos casos presentaron similitudes, pero debido a que las dificultades 
y las finalidades en el uso de la información son distintas, cambia inclusive la forma de comercializar con ella.

La sociedad del conocimiento (distinguida por el uso masivo de TIC, la globalización y los procesos productivos basados en las ciencias) impacta no sólo a las formas de producción, sino también al mundo de investigación. Los procesos de innovación que incluyen a la investigación y la puesta en marcha de sus resultados se producen cada vez más en forma colaborativa, es decir, en redes donde las conexiones entre los diferentes ámbitos son cruciales para el éxito de las innovaciones. Pero el éxito de estas redes depende en gran medida de las competencias de las personas que las integran, es decir, del capital humano. Estas "competencias de actuar en red" son nuevas y de suma importancia para asegurar la competitividad de las empresas, los sectores económicos y regionales, pero, sobre todo, para que las personas puedan desenvolverse en esta nueva "sociedad del conocimiento" (Krügger, 2000).

LOS PROFESIONALES DE LA

INFORMACIÓN Y LOS SECTORES PRODUCTIVOS

El doctor Rodríguez Gallardo dio una palabras muy acertadas en la XII Conferencia Internacional sobre Bibliotecas Universitarias bajo el tema "La biblioteca y el sector productivo", con las que señaló que hoy en día algunas figuras modernas de la administración de negocios como la inteligencia competitiva, la gestión del conocimiento, el estudio y la tecnologización del mercado, la innovación y la reingeniería están basadas en la obtención, organización y análisis de la información especializada. Todos estos aspectos son capitalizados como un activo o insumo por los grandes negocios internacionales. Asimismo, señaló que se llevan a cabo una gran 
cantidad de acciones estratégicas de diversos organismos de todo tipo a nivel mundial que son respaldados con información virtual, y se considera que muchas de estas acciones son encaminadas a mejorar la economía o a desarrollar algunos de los sectores productivos del país.

El doctor Rodríguez Gallardo también señaló que tanto las bibliotecas universitarias como las especializadas y de investigación cuentan en sus acervos con recursos de información, colecciones documentales y obras de técnicas consulta que resultan ser estratégicas y de gran importancia para las diversas acciones que llevan a cabo las empresas en los diferentes sectores que constituyen la actividad económica y de negocios de cualquier país, en este caso, México.

\section{Conclusiones}

El impacto de los recursos y servicios de información, ya sean analógicos o digitales, a través de las Tecnologías de la Información y la Comunicación (Tic) ha tomado una relevancia primordial en los sectores económicos y productivos de nuestro país, por lo que se configura como uno de los pilares de la nueva economía o economía digital. El impacto de la revolución que suponen los contenidos informativos es un fenómeno complejo, objeto de estudios académicos de diversas disciplinas científico-técnicas y socioeconómicas, y está en el centro de las políticas económicas de países avanzados, desarrollados y en desarrollo pues, como se menciona en muchos ámbitos, "la información es poder". La información, por ende, es el núcleo que permite que se concreten los acuerdos comerciales tanto a nivel nacional como internacional. Además, sirve para llevar a cabo la integración de mercados globales, acelerar la innovación y 
favorecer la gestión de las organizaciones, así como para mejorar la calidad de vida de los individuos.

Brindar información a estos sectores es una labor que indudablemente los profesionales de la información tienen que llevar a cabo con la finalidad de ofrecer respuestas eficientes y efectivas ante las necesidades humanas cada vez más complejas. Los sectores productivos han evolucionado de manera paralela a las actividades de la vida actual. Su devenir está fundamentalmente condicionado por el desarrollo de nuevas soluciones tecnológicas, que no sólo han determinado el grado de eficiencia y eficacia de las respuestas ofrecidas a las nuevas necesidades que han ido surgiendo en las distintas etapas históricas, incluyendo las de índole informativo, sino también han guiado las transformaciones y los avances de ciertas ramas de la actividad económica que, finalmente, han terminado por emanciparse de su sector originario y troncal, dando lugar a nuevos sectores productivos. Esto ha ocurrido con el terciario, que se considera un sector no productivo puesto que no produce bienes tangibles, y también con otros sectores como el cuaternario o de la información y el quinario, en donde entra la industria del entretenimiento. 


\section{Bibliografía}

Becheik, N., R. Landry y N. Amara. (2006) "Lessons from Innovation Empirical Studies in the Manufacturing Sector: A Systematic Review of the Literature from 1993-2003." Technovation, 25 (5-6), 644-664. doi:doi.org/101016/j.technovation.2005.06.016.

Friedman, M. (2000).Commanding Height. Sitio disponible en: https://www.pbs.org/wgbh/commandingheights/shared/minitext/int_miltonfriedman.html.

Krügger, K. (2000). "Proceso de innovación y difusión de conocimientos en empresas". Scripta Nova, 69 (31).

Mejía Gutiérrez, Á.M. Recursos y servicios de información en línea en el Sistema de Bibliotecas de la Universidad de los Andes en Bogotá, Colombia. Disponible el 18 de julio de 2016 en: http:// www.uma.es/publicadores/biblioteca/wwwuma/02_COLOMBIA1.pdf.

Pérez Zuñiga, R., O. Camacho Castillo y G. Arroyo Cervantes (2013). "El incremento de la productividad y competitividad en México: Innovación, conocimiento y desarrollo". Revista de Tecnología y Sociedad, 3 (5). Disponible en: http://www.udgvirtual. udg.mx/paakat/index.php/paakat/article/view/204/290.

Wolfe, R.A. (1994). Organizational Innovation: Review, Critique an Suggested Research Directions. Journal of Management Studies, 31 (3), 405-431. 


\title{
El uso de la información desde la visión del consumidor: la Profeco
}

\author{
Rodolfo García García \\ Procuraduría Federal del Consumidor
}

\section{INTRODUCCIÓN}

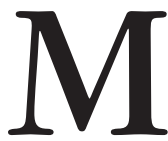

ejorar la toma de decisiones al realizar compras o alguna transacción comercial hoy en día requiere de un enfoque metódico, razonado y formal que permita enfrentar la complejidad dada por el gran número de variables involucradas en este proceso. Esto es un reto que implica varios obstáculos y en el que las tecnológicas y sistemas inteligentes impactan en los sectores productivos y económicos. Es fundamental contar y preparar a personal profesional en la información, debido a que éste juega un rol fundamental en el camino de aumentar el valor de la información. Con los factores citados, se pueden defender los derechos de los consumidores, prevenir abusos y garantizar relaciones de consumo justas.

Inicios del Derecho de Protección al Consumidor

Al referirnos a la materia de la protección al consumidor, debemos remontarnos a sus antecedentes, lo cual es de gran 
importancia porque la historia de la civilización se ha vinculado directamente con los actos de comercio; día a día van originándose nuevas formas para comercializar productos y servicios, por lo cual ha surgido la necesidad de avances jurídicos encaminados a la protección de los derechos del consumidor, así como de la literatura correspondiente. En tal virtud, las siguientes líneas están destinadas a exponer el desarrollo de las actividades comerciales, ya que son una fuente directa del derecho del consumidor.

\section{Primer movimiento de consumidores (1906)}

"Desde inicios del siglo $\mathrm{xx}$, los consumidores llevaron a cabo movimientos en Estados Unidos de América, motivados fundamentalmente por el aumento de precios y la venta de alimentos y substancias farmacéuticas sin control alguno"(García García, 2016: 9).

El movimiento inicial se desarrolló en el primer decenio del siglo $\mathrm{xx}$ y fue provocado, entre otros factores, por el aumento de los precios, los escritos polémicos de Upton Sinclair ${ }^{7}$ y los escándalos derivados de las substancias farmacéuticas. Este movimiento culminó con la aprobación de la Ley sobre la Genuinidad de las Substancias Alimenticias y Farmacéuticas de 1906; Ley sobre Inspección de Carne del mismo año, y con la creación, en 1914 de la Comisión Federal Para el Comercio (Ovalle Favela: 2001 3-4).

7 En 1904, Fred Warren, editor del periódico socialista Appeal to Reason, le encargó a Upton Sinclair un reportaje sobre las malas prácticas de la industria alimentaria que se convirtió en la novela La jungla, un éxito de ventas sin precedentes y un enorme revuelo internacional. Como consecuencia, el presidente Theodore Roosevelt, aunque muy alejado políticamente del socialismo de Sinclair, recibió al autor en la Casa Blanca y puso en marcha leyes para asegurar la calidad de los alimentos para el consumo humano. 


\section{SEgundo MOVImiento (AÑos TREINTA)}

Con motivo de la depresión económica ocurrida durante los años treinta en los Estados Unidos de América, se registró un nuevo aumento de precios, consecuentemente los consumidores se manifestaron por segunda ocasión y exigieron protección contra las actividades fraudulentas de los proveedores y los incrementos desmedidos de los precios.

Esta protesta tuvo lugar sobre la mitad del decenio de los treinta, fue motivada por un desmesurado incremento de los precios al consumidor en plena depresión económica, el escándalo de la sulfanilamida y la huelga de las amas de casa en Detroit. La protesta culminó con las reformas para fortalecer la Ley sobre la Genuinidad de las Substancias Alimenticias y Farmacéuticas de 1906, y la ampliación de los poderes normativos de la Comisión Federal para el Comercio, todo ello encaminado a combatir las actividades y las prácticas ilícitas o fraudulentas (ibidem: 9).

\section{TERCER MOVIMIENTO DE CONSUMIDORES (AÑOS SESENTA)}

Algunos medicamentos como la talidomida, el aumento de precios y la publicidad llevada a cabo por medios masivos de comunicación causaron durante los años sesenta el tercer movimiento de consumidores estadounidenses. Este movimiento

[...] es el resultado de una compleja convergencia de circunstancias, las cuales una de las más importantes es el contraste entre las prácticas habituales del comercio y los intereses a largo plazo de los consumidores. Los orígenes de este movimiento son consecuencia de diversos factores, entre los que se mencionan a Ralph Nader, el escándalo de la talidomida, el aumento de los precios y la acción de los medios de comunicación masiva (ibid.: 4). 
ConSECUENCIAS DE LOS MOVIMIENTOS

DE CONSUMIDORES VERIFICADAS ENTRE LOS PAÍSES EUROPEOS

El movimiento de consumidores de los sesenta

[...] se extendió a los países europeos. Surgieron asociaciones privadas de consumidores; se imprimieron revistas y artículos en defensa de los consumidores; aparecieron las primeras transmisiones radiofónicas y televisivas dedicadas a la información y a la educación de los consumidores; se realizaron congresos, mesas redondas, debates sobre la posición del consumidor y sus derechos, y, en fin, se crean organismos administrativos para la tutela de los intereses de los consumidores en Francia, Inglaterra, Suecia y Holanda (García García: 5).

De lo expuesto, es posible inferir que el Derecho de Protección al Consumidor se creó no por la iniciativa de los Estados, sino en virtud de la exigencia de los consumidores que se manifestaron durante más de medio siglo, así como derivado de las presiones internacionales. Esto debe servir como un referente para llevar a cabo nuevas acciones, ahora encaminadas a lograr que las instituciones protectoras de los derechos del consumidor se conviertan en organismos autónomos, en lugar de estar supeditadas a las dependencias de economía y comercio cuyas funciones son antagónicas.

Los CONSUMIDORES EN MÉXICO

En 1976 se promulgó la Ley Federal de Protección al Consumidor (LFPC) y surgió Profeco como la institución encargada de defender los derechos de los consumidores, prevenir 
abusos y garantizar relaciones de consumo justas. México se convirtió en el primer país latinoamericano en crear una procuraduría y el segundo con una ley en la materia.

Seis años después, en 1982 la institución ya tenía 32 oficinas en las principales ciudades del país. En la actualidad, Profeco cuenta con un total de 32 delegaciones y 19 subdelegaciones, lo cual suma un total de 51 oficinas en toda la república (Profeco, 2016).

La Profeco es una institución que sirve para apoyar al consumidor y mantenerlo al tanto de buenas prácticas a partir de las publicaciones que genera. Tiene como misión ser una institución que proteja y promueva los derechos de las y los consumidores, garantizando relaciones comerciales equitativas que fortalezcan la cultura de consumo responsable y el acceso a productos y servicios en mejores condiciones de mercado, asegurando certeza, legalidad y seguridad jurídica dentro del marco normativo de los derechos humanos reconocidos para la población consumidora.

En la actualidad dicha institución participa en la sociedad de manera muy activa para llevar estrategias que permitan ir acordes a la filosofía de gobierno abierto mediante las siguientes acciones:

- Garantizar la transparencia y la calidad en la prestación de los trámites y servicios, así como información eficaz.

- Contar con mecanismos de participación ciudadana para conocer la opinión de los y las usuarios/as sobre la calidad de los trámites y servicios.

- Buscar siempre soluciones innovadoras que permitan a la Institución alcanzar resultados de valor y credibilidad.

- Generar confianza y credibilidad en la ciudadanía.

- Mejorar los trámites de acuerdo con las necesidades de la ciudadanía. 
- Reunir en un sólo espacio la mayoría de los trámites y servicios que ofrece Profeco.

- Brindar atención integral en todas las ventanillas de contacto ciudadano (todo el personal está capacitado en todos los trámites y servicios).

- Reducir al mínimo el tiempo de atención.

- Brindar un espacio cómodo y agradable al ciudadano mientras espera (Profeco, 2016).

Al colaborar con tales acciones también permite que el consumidor se involucre y participe de manera más activa en cuestiones relacionadas con compras bien pensadas, tomando la información que el propio instituto genera a partir de investigaciones de campo y sondeos.

EL CONSUMIDOR Y LA INFORMACIÓN

EN MATERIA MERCANTIL Y COMERCIAL

Para entender el comportamiento del consumidor, muchos autores se han abocado a su estudio desde diferentes perspectivas; sin embargo, los estudios en el área bibliotecológica son escasos o casi nulos. En otros aspectos, este comportamiento se ha analizado desde diversos enfoques, por ejemplo, se ha abordado desde la parte legal o psicológica, según la cual se estudia cómo en el proceso de consumo que el individuo, grupos u organizaciones tienen que llevar a cabo intervienen diferentes factores mentales; así como el razonamiento que usan para seleccionar, comprar, usar y desechar productos, servicios, experiencias o ideas para satisfacer necesidades; además del impacto que estos procesos tienen en el consumidor y la sociedad. Aunque la mayor preocupación de estos estudios es entender el uso que 
el comprador hace de los productos, no se deben dejar de considerar otros aspectos como la forma de desecharlos, ya que hay una serie de problemas ambientales de gran impacto derivados de esto; o como la manera en que se utiliza la información para llevar a cabo compras más adecuadas.

La información para la toma de decisiones en cualquier ámbito siempre ha sido bien recibida. Esto ha sido especialmente considerado por las empresas, debido a que tomar una mala decisión por falta de información los puede llevar a pérdidas millonarias. Sin embargo, esto no es contemplado por la gran mayoría de consumidores, y es una lástima ya que al encontrarnos en un ambiente global y altamente competitivo, es muy complicado realizar buenas compras. Esta situación lleva a algunos consumidores y a algunas organizaciones a enfrentar los mercados con cautela.

Al hablar de una eficiente gestión de la organización, es imprescindible tomar en cuenta un factor clave que es la toma de decisiones. Este proceso puede considerarse la base del éxito de las buenas finanzas personales.

Un consumidor debe estar atento a costos, calidad y pertinencia de los productos para que en el momento en que tenga que llevar a cabo una compra pueda decidir entre miles de marcas o muchos mercados. Además de que debe hacer sus compras considerando que éstos sean:

- Oportunas.

- Rápidas.

- Informadas.

- Efectivas.

- Eficientes (en uso de recursos).

La información tiene que ser diferenciada de otro concepto que es el ruido debido a que la característica principal 
de la información es que debe ayudar a resolver el problema al que se tiene que enfrentar la persona que toma una decisión. Se entiende por decisión el proceso de transformación de la información en acción.

Esta definición de la toma de decisiones nos permite considerar la información con el input (entrada) de la decisión y advertir además que sin información no puede haber decisión. Además, el grado en el cual se acierta en la decisión depende de la calidad, cantidad y oportunidad de la información disponible. Si además se reflexiona que la administración es un proceso global de toma de decisiones no es fácil deducir la importancia vital que tiene para cualquier consumidor o institución la información. La información será necesaria para cualquier tipo de planificación (El Ergonomista, s.f., s.p.).

Ahora bien, ¿cuáles serían los posibles obstáculos cuando uno tiene que utilizar información para la toma de decisiones? Caiceo (2012) menciona que para que dicho proceso genere decisiones alineadas con los objetivos estratégicos de la organización, es esencial que los sistemas de información también estén integrados, ya que ello puede proporcionar mayor confianza y flexibilidad para enfrentar las distintas barreras que puedan surgir en la toma de decisiones. Entre estos posibles obstáculos destacan los siguientes:

1.- La ansiedad que puede llevarnos a tomar decisiones de manera impulsiva.

2.- La falta de información que nos impide disminuir la incertidumbre de la decisión.

3.- Contar con información equivocada que nos lleve a tomar decisiones erróneas.

4.-Poseer demasiada información o información redundante, lo cual aumenta el tiempo de la toma de decisión. 
LOS TEXTOS EN MATERIA DE

PROTECCIÓN AL CONSUMIDOR RECOPILAdOS POR PROFECO

A finales del 2001, comenzó el proyecto para el acondicionamiento de las instalaciones del CEDOC en la Procuraduría Federal del Consumidor con el propósito de poner al alcance del público el material informativo que esta institución ha recopilado y generado como parte de su tarea cotidiana.

Fue hasta marzo de 2003 que se concretó dicho proyecto, en un espacio específicamente diseñado para proporcionar servicio a los servidores públicos de la institución, así como a los estudiantes, consumidores y proveedores que requirieran algún material.

\section{A. Material con que cuenta el CEDOC}

El material con que cuenta el CEDOC es el siguiente:

- Revistas.

- Acervo bibliográfico de 2,166 libros publicados por Profeco, el Instituto Nacional del Consumidor ${ }^{8}$ y otras editoriales; adquisiciones de Profeco y donaciones.

- Otro tipo de materiales: audiovisuales, documentos electrónicos, etcétera.

B. Textos objeto de consulta Desde los inicios del CEDOC de la Procuraduría Federal del Consumidor, los textos solicitados se concentraron en la $R e-$ vista del Consumidor, así como en los libros en materia de

8 En 1979, en lo que era el Instituto Nacional del Consumidor (INCO), surgió la primera biblioteca sobre consumo. Estaba constituida, además de libros, por una hemeroteca y una videoteca, constaba de aproximadamente cuatro mil documentos. Cuando el Inco se fusionó con la Profeco en 1993, este centro cerró sus instalaciones; sin embargo, se integró a la Dirección General de Publicaciones un área limitada, destinada al préstamo y consulta de la Revista del Consumidor. 
consumo publicados por dicha institución y el INCO. A partir de la publicación del Tratado sobre Derecho de Protección al Consumidor por la editorial Porrúa, los usuarios de dicho servicio han preferido consultar esta obra, tendencia que aumentó a partir de la segunda edición, publicada en el año 2016 (García García, 2016).

\section{Revista del Consumidor}

El primer número de la Revista del Consumidor se imprimió en noviembre de 1976. Hasta la fecha, se han impreso un total de 475 números todos ellos forman parte del acervo del CEDOC y están a la disposición de los consumidores. Para préstamo, se cuenta con ejemplares de noviembre de 1976 a noviembre de 2016; para venta, se cuenta con ejemplares desde enero de 2011 con un costo de $\$ 28.00$ pesos.

D. Libros en materia de consumo

publicados por Inco y Profeco

La totalidad de los libros publicados por Profeco e Inco están referidos al tema de consumo, al igual que las revistas; no así a la materia de derecho de protección al consumidor. Fundamentalmente, abordan los siguientes temas:

- Información y publicidad.

- Investigaciones realizadas por Profeco acerca de la calidad de bienes y servicios.

- Tecnologías domésticas.

- Educación sobre consumo dirigida a niños.

- Educación sobre consumo dirigida a jóvenes.

- Consumo internacional.

- Consumo sustentable para preservar el medio ambiente.

- Temas relativos a consumo de temporada: regreso a clases, vacaciones, fiestas tradicionales, Navidad, Día de reyes, etcétera. 
E. Uso de los servicios en el CEDOC

No se requiere llenar ningún tipo de solicitud ni presentar alguna credencial o identificación para tener acceso al servicio, es suficiente acudir con las dudas o inquietudes que sobre consumo se tengan.

El personal del Centro de Documentación está en la mejor disposición de ayudar al público en su búsqueda, así como canalizarlo a la instancia correcta, en caso de que la información que necesite sea competencia de otra dependencia de gobierno o centro educativo o de investigación.

F. Usuarios que frecuentan el Centro de Documentación Los usuarios del CEDOC de Profeco son trabajadores de la misma institución, investigadores, estudiantes y consumidores.

- Estudiantes. Este grupo de usuarios contempla el rango de entre los 18 y 45 años de edad.

- Jóvenes. Este grupo está integrado entre el rango de edad de 12 a 29 años.

- Adultos. Este grupo incluye personas con edad de 30 a 59 años.

- Investigadores. El rango de edad está entre los 30 y 55 años.

G. Temas consultados con mayor frecuencia Los más consultados son los temas relacionados con el derecho de protección al consumidor previsto en distintas leyes, así como los procedimientos a substanciar, contenidos en el Tratado sobre Derecho de Protección al Consumidor, ${ }^{9}$ referido con anterioridad. En síntesis, son los siguientes:

9 Este tratado es la obra más completa que se ha publicado sobre la materia de protección al consumidor. El prólogo a la segunda edición fue elaborado por el licenciado Rafael Ochoa Morales, subprocurador jurídico de la Procuraduría Federal del Consumidor. 
1. Temas eminentemente jurídicos

Temas que pertenecen a sistemas jurídicos diversos, cuya vigilancia corresponde no sólo a la Profeco, sino también a las siguientes instituciones: CONDUSEF, CONAMED, COFEPRIS, IFT y COFECE. Una obra en su totalidad contiene los conocimientos necesarios para un nivel particular de especialización.

La finalidad primordial de la obra jurídica consiste en resolver la carencia de estudios reflexivos y sistematizados en la materia que nos ocupa y solucionar la problemática relacionada con la misma, de la cual es notoria su limitada eficacia.

El estudio parte del surgimiento del Derecho de Protección al Consumidor, y pasa por las tesis relativas a los derechos humanos de sus titulares y su evolución hasta llegar a su reconocimiento por la onU.

Dichos trabajos de investigación profundizan en todos los procedimientos sobre la materia: evaluación de la conformidad, métodos de prueba, muestreo, verificación, conciliación, procedimiento por infracciones a la ley, arbitraje, acciones colectivas, procedimientos en materia de telecomunicaciones, registro de contratos de adhesión, recursos de revisión y revocación, los distintos juicios contencioso-administrativos ante el Tribunal Federal de Justicia Administrativa, incluyendo aquellos contra la CFE, los seguidos por Cofece, etcétera, y las jurisprudencias y tesis aisladas.

Además se analizan temas particulares entre los que destacan la naturaleza jurídica de la sanción administrativa, medidas de apremio y precautorias, valoración de la prueba, metrología y normalización, y delitos con motivo de las relaciones de consumo. Asimismo, se aborda el tema de actualidad e interés mundial relativo a la Tercera Revolución Industrial, por tanto contamos con un trabajo exhaustivo. 
2. Temas en materia de consumo

Información relativa a temas de novedad como el apagón analógico, información crediticia y acciones de la Profeco; en Internet se pueden consultar los servicios que ofrece la Procuraduría como el "Quién es Quién" en los precios, canasta básica y normatividad diversa, información de tecnología doméstica y "Platillo Sabio", estudios de calidad, así como el uso de Internet en diversas páginas de la Profeco e instituciones gubernamentales. De igual forma, a través del envío de un correo electrónico se les brinda a los suscriptores acceso a información sobre reportes de temas especiales. Otros temas que pueden consultarse son los antecedentes de Profeco, su organigrama, su código de ética, los pasos de un consumo inteligente, los derechos de los consumidores, los valores de Profeco; su misión, visión y objetivos, la calidad de los útiles escolares, y multifuncionales.

Algunas veces, los usuarios hacen consultas relacionadas con las frases que ha empleado la Procuraduría Federal del Consumidor para captar la atención. A continuación se citan las principales:

- Si de precios te quieres enterar, sólo un número tienes que marcar: 55688722 (Instituto Nacional del Consumidor).

- Si la leche es poca, al niño le toca.

- Esta ley es suya, hágala valer.

- Regale afecto, no lo compre.

- Cómo, cuándo y dónde quejarse.

- En esta Cuaresma, no sólo de pescado vive el hombre.

- En esta Cuaresma, en la variedad está el ahorro.

- Profeco te protege y asesora.

- El juguete caro no es siempre el más adecuado.

- Antes de comprar, se debe informar.

- Listos con la lista. 
- Litros de a litro.

- En el súper o en el mercado, ir bien informado da buen resultado.

- Celebremos nuestras tradiciones.

- Compara precios antes de comprar.

- Imaginar es lo que cuenta para jugar.

- Al mercado por pescado, ve bien informado.

- El aprecio no se demuestra con el precio.

- ¡Águila con su aguinaldo!

- El aguinaldo es un derecho, no un regalo navideño.

- Ésta es la nueva Profeco, defensora del consumidor.

H. Convenios interbibliotecarios

La Dirección General de Planeación y Evaluación, a cuyo cargo está el CEDOc de la Procuraduría Federal del Consumidor, ha celebrado diversos convenios interbibliotecarios con distintas instituciones universitarias; el más sobresaliente es el que suscribió con la Biblioteca Central de la UNAM.

IMPACTO DE LAS CONSULTAS REALIZADAS AL CEDOC

En conclusión, los resultados, que derivan de las consultas de libros y revistas al CEDOC de la Procuraduría Federal del Consumidor, son los siguientes:

- Los consumidores han encontrado elementos para realizar la mejor elección de productos y servicios.

- Los usuarios del CEDOC adquieren información relacionada con productos y servicios de temporada, por ejemplo: útiles y uniformes escolares, centros vacacionales, precios de productos como pescados, mariscos, frutas, legumbres, etcétera. 
- Es recurrente la consulta del "Platillo Sabio", el cual apoya a los consumidores en su alimentación y economía.

- Los consumidores se enteran de temas de vanguardia, particularmente los relativos a la reforma energética, tales como el apagón analógico, los servicios de Internet, telefonía celular y televisión por cable.

- Asimismo, el público se informa de los servicios que proporciona la Procuraduría Federal del Consumidor.

- Los estudiantes de diversos niveles adquieren conocimientos en relación a los antecedentes de Profeco, su organigrama y el código de ética.

- En lo que se refiere a temas eminentemente jurídicos, los abogados de la Procuraduría Federal del Consumidor han encontrado elementos suficientes para fundar y motivar sus actuaciones.

- Quienes realizan trabajo de investigación, han encontrado el material necesario para continuar y, en su caso, concluir su actividad.

- Los estudiantes que realizan su tesis en materia de protección al consumidor han encontrado en el CEDOC los ingredientes necesarios para encaminarla correctamente, así como para culminarla. - En general, los consumidores encuentran en el material del CEDOC de la Profeco los medios necesarios para atender uno de sus derechos fundamentales reconocidos tanto por la onu como por la Ley Federal de Protección al Consumidor: la educación en materia de consumo.

Con el uso de todos estos contenidos, se ha podido mejorar la toma de decisiones en los sectores productivos y económicos de nuestro país. La Profeco ha sido una institución involucrada en tal fin, y en apoyar y defender los derechos de los consumidores por medio de información pertinente y actual con la cual se realizan compras más razonadas. 


\section{Bibliografía}

Caiceo, J. (2012). "El valor de la información para la toma de decisiones”. Revista Gerencia. Disponible en: http://www.emb.cl/ gerencia/articulo.. vvc?xid=372.

El Ergonomista. "Papel de la información en la toma de decisiones". Disponible el 12 de julio de 2017 en: http://www.elergonomista.com/relacioneslaborales/rl79.html.

García García, R. (2016). Tratado sobre derecho de protección al consumidor. México: Porrúa.

(2005). Tratado sobre derecho de protección al consumidor. México: Porrúa

Ovalle Favela, J. (2001). Derechos del Consumidor. México: Cámara de Diputados (LvIII Legislatura) / unAm.

Profeco (2016). Portal de la Procuraduría General del Consumidor. Disponible en: http://www.profeco.gob.mx/n_institucion/q_somos.asp. 


\section{Uso de la información por los consumidores y fabricantes del sector textil}

Cinthya de Jesús Ríos Flores

Biblioteca Hispano-Mexicana "Carlos Prieto"

\section{INTRODUCCIÓN}

T a industria textil no es un mundo ajeno al ámbito bibliotecológico. Los datos que arrojan cada uno de estos materiales significativos como información transforman al textil en un documento factible de organizarse. A continuación, se presenta un panorama del ámbito textil en México, de su tratamiento de la información y de cómo estos objetos contribuyen al desarrollo y la difusión del trabajo artesanal de los productores de textiles indígenas, al conocimiento y la colaboración de la industria textil contemporánea y, en general, al enriquecimiento de este ámbito productivo. Además, se presenta la aplicación de un catálogo especializado en estos materiales como una herramienta útil de resguardo y organización de estos valiosos acervos documentales.

Sector textil en México

México es un país multicultural con una larga tradición textil. Por un lado, se puede observar diversidad en los diferentes 
trajes típicos de las regiones del país, herederos de las culturas prehispánicas; por otro, la industria establecida ha llevado opciones de desarrollo a diferentes regiones. Sin embargo, en los últimos años una parte importante de este sector ha sufrido una contracción debido al desplazamiento de la maquila a productos exportados a Estados Unidos por competidores de otros países, principalmente del sureste asiático y China.

El panorama multiétnico que conforma nuestro país resulta en un conjunto de códigos y símbolos que llamamos identidad, lo que hace que la cultura funja como una voluntad colectiva transmisora de su herencia social y que se materializa en objetos utilitarios, que conllevan un gusto estético y refinado.

Tanto la moda como el arte se basan en tradiciones compartidas que están en constante cambio, evolucionando hacia nuevas formas, lo que permite que el individuo se sienta identificado en un entorno y grupo social específico. Las modas y los grupos sociales se adecúan a las necesidades de una sociedad ávida de consumo y por ello es importante que se reconozcan y valoren las materias primas con las que por naturaleza y riqueza cultural cuentan, los textiles indígenas, que a su vez se adaptan a la moda contemporánea.

Según el Instituto Nacional de Estadística y Geografía (INEGI), la industria textil en su conjunto registró en 2011 un valor de ventas de productos manufacturados por $\$ 89,448.00$ millones de pesos, un $2.38 \%$ del PIB manufacturero ( $\mathrm{Tu}$ interfaz de negocios, 2013), y obtuvo ingresos provenientes de maquila por $\$ 23,163.00$ millones de pesos. En cuanto a sus indicadores mensuales, la fabricación de prendas de vestir representa un valor del $\mathbf{9 8 . 9 \%}$ de la actividad industrial en nuestro país. 
Estas cifras no desestiman la importancia de esta industria en México. Sin embargo, las estadísticas que no se conocen a ciencia cierta son las de la producción textil indígena, como si se estuviera anticipando que este tipo de arte no se puede medir.

En las comunidades indígenas, las mujeres tienen un papel importante dentro de las actividades económicas, y son las que emigran a la ciudad para recibir una remuneración por las actividades que comúnmente realizarían en sus comunidades, como son la cría de animales, el cultivo de hortalizas o la elaboración de artesanías (INEGI, 2004).

En este último trabajo, tan exclusivo de las mujeres, siempre ha existido la disputa de definirse como arte o artesanía, pero fuera de ello, lo que queda muy claro es que cada una de estas piezas son únicas e irrepetibles creaciones de los diversos indígenas que conforman nuestro país multicultural.

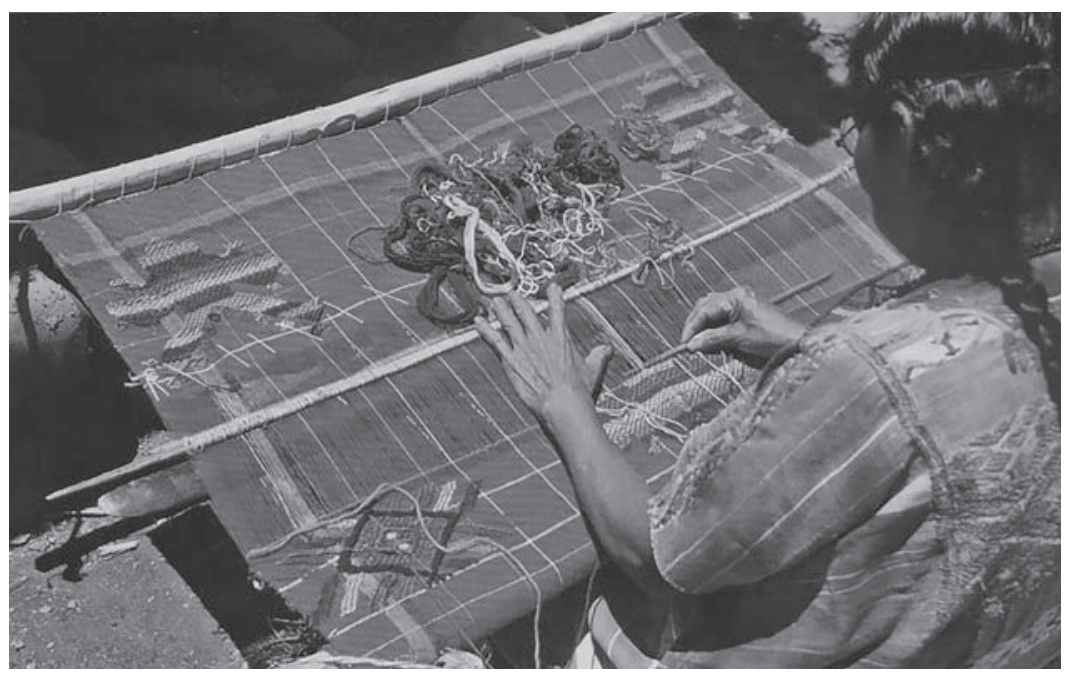

Tejedora chinanteca usa un palo delgado para levantar las urdimbres e insertar las tramas de un motivo de brocado discontinuo en un paño. San Felipe Usila, Oaxaca, 1952.

Fuente: Kirsten Johnson (2015: 131). 
USO DE LA INFORMACIÓN POR LOS CONSUMIDORES Y FABRICANTES

Pero, ¿de qué sirve conocer un textil indígena, organizar la información que contiene, resguardarlo y preservarlo? A los consumidores y pequeños empresarios les permite mejorar su entorno y preservar sus tradiciones, por ejemplo: en Mesoamérica, las mujeres de todas las clases sociales elaboraban las telas en telar de cintura y las adornaban con bordados, aplicaciones de conchas, piedras preciosas, etcétera, que ahora han servido de influencia para diseñadores que los anexan en sus colecciones y los proyectan nacional e internacionalmente.

Marcas y organizaciones se han dado a conocer por su arraigo a las culturas mesoamericanas, y han fomentado vinculaciones de apoyo entre agrupaciones indígenas que colaboran con su trabajo en la creación de hermosas prendas; de esta manera enriquecen pasarelas y la moda mexicana, y también corresponden con la difusión del increíble trabajo que realizan y con la formación de fundaciones que ayudan a la cohesión social y la reintegración del tejido social entre comunidades.

Es así como el conocimiento de esta información permite identificar mercados de productos textiles originales y de alta calidad, y fortalece las capacidades técnicas de los creadores y artesanas, así como fomenta su participación organizativa. Además, surgen espacios donde se pueden intercambiar conocimientos y capacitaciones de los interesados, y mercados donde se ofrecen productos con técnicas de herencia cultural de nuestro país combinados con los requerimientos del consumidor actual.

Como ejemplo particular, la Comisión Nacional para el Desarrollo de los Pueblos Indígenas, que en adelante se denominará CDI, tiene como objetivo resguardar y promover el arte y la cultura indígena a través de sus distintos museos (CDI, 2016a).

La CDI cuenta con seis acervos que difunden la pluralidad de los grupos indígenas, las características de su vida cotidiana, sus 
ritos y costumbres, su cosmovisión, forma de organizarse y producción económica. Todos estos elementos son dados a conocer a la población heredera de la cultura prehispánica de México. Los acervos son: acervo bibliográfico de la biblioteca Juan Rulfo; acervo de cine y video Alfonso Muñoz; fonoteca Henrietta Yurchenco; fototeca Nacho López; mapoteca Germán Parra, y el Acervo de Arte Indígena (CDI, 2014).

Este último Acervo de Arte Indígena resguarda las piezas creadas por artesanos de toda la República Mexicana, es una de las mayores colecciones de textiles, y es un indicador más de la importancia de estos objetos, ya que conserva en mayor medida la pureza de técnicas prehispánicas, que para Marín de Paalen son "de entre todas las artesanías, las que se manifiestan con mayor diversidad en sus tejidos, decorados y teñidos, y ello contribuye a otorgarles un valor de primerísimo orden entre las demás" (Marín, 1974: 78).

Los usuarios principales de estos objetos son investigadores y académicos interesados en presentar trabajos de investigación histórica, antropológica y sociocultural de la población indígena, así como artesanos directamente involucrados en estos diferentes acervos.

Como parte del trabajo documental de estos materiales, la CDI gestionó la creación de un catálogo especializado con el registro de cada una de las piezas de arte indígena que conforman su acervo de más de 23 mil ejemplares, agrupados en más de veinte ramas artesanales. Cada uno de los elementos, cada detalle que forma un textil indígena está cargado de información histórica y cultural de nuestro país. El proceso de su elaboración implica la recolección de la fibra, el hilado, el teñido, la técnica del tejido, el decorado con íconos significativos y el uso de la prenda que representará estatus o pertenencia; en cada elemento mencionado se pueden observar datos históricos y de cosmovisión indígena. 
Mayor desglose merece la significación de su iconografía, que vale todo un estudio antropológico para conocer la cosmovisión y tradición de profundas raíces culturales de los pueblos indígenas, diversas y en continua transformación.

Por mencionar un detalle, los mesoamericanos, al no poder explicarse los fenómenos naturales, recurrieron a los mitos y supersticiones para comprender su entorno y tomaron a los dioses como protectores o amuletos que debían llevar con ellos a todas partes; por lo que, primero, el cuerpo fue el medio para llevarlos mediante los tatuajes y, con el paso del tiempo, los textiles se encargaron de portar los símbolos asociados a las deidades. Por ejemplo, al no comprender la fertilidad, ésta fue asociada al sapo y a la lagartija como seres con el poder de fecundar a la mujer. Velasco en su obra Origen del textil en Mesoamérica (Velasco, 1995: 119) argumenta que tal vez esta asociación surgió al comparar el parecido de los abortos fetales con estas criaturas, y posteriormente plasmaron este símbolo en sus tejidos.

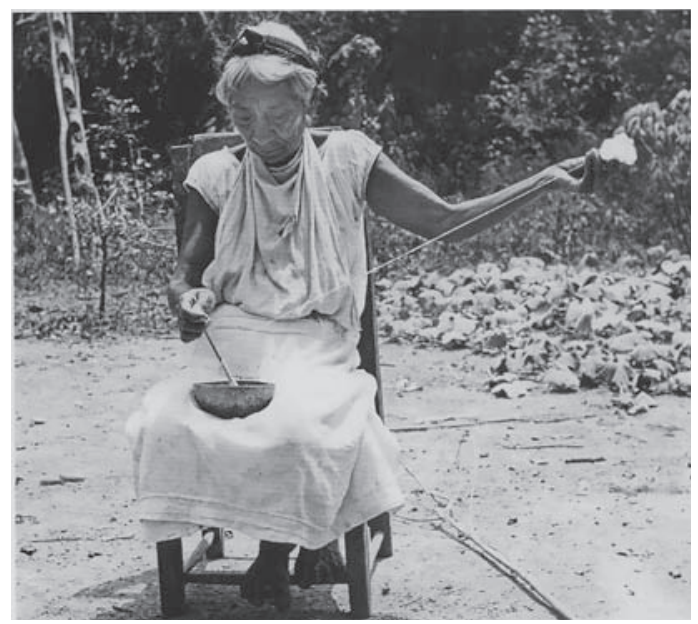

Mujer totonaca hilando algodón, El Tajín, Papantla, Veracruz, 1953.

Fuente: Kirsten Johnson (2015). 
Cada uno de los registros que conforman este catálogo son testimonios de toda la información que representa el textil indígena, lo que lo convierte en un documento tangible de la cosmovisión de los pueblos, que se puede encontrar en gran variedad de formas, y, lo más importante, representa un documento único sin oportunidad de copias.

Para esquematizar, se detallan los siguientes resultados obtenidos de la funcionalidad de estos catálogos especializados:

- La utilidad como herramienta de combinación de saberes y técnicas antiguas, novedosas y destacadas en los ejemplares contemporáneos.

- Se tiene un testimonio documental que presenta el recorrido histórico y de diseño de cada una de las piezas textiles, y la información que se puede encontrar en los registros de textiles indígenas. Esta información contiene datos de procedencia de la pieza (como fecha de elaboración, lugar de procedencia, artesano creador); descripción física en la que se especifican elementos físicos de la pieza; descripción de la técnica, donde se menciona la fibra utilizada, el hilado, el teñido, la técnica del tejido, el decorado con íconos significativos; datos históricos de la prenda, su uso y del significado de los símbolos utilizados.

- La información iconográfica es de gran valor cultural, en ésta se puede encontrar el significado de colores como el blanco, que está relacionado con el crepúsculo; el rojo con la sangre; el fuego; el color del Dios Sol; los puntos cardinales; los atributos de las deidades y cada elemento de la naturaleza con su propio significado.

- Los datos provenientes de piezas antiguas y en desuso describen técnicas que el artesano utiliza para preservar las técnicas tradicionales de su comunidad, por lo que el catálogo representa una fuente rica en información para el rescate de métodos de elaboración, inclusive muchos de los artesanos encuentran piezas que pertenecieron a algún familiar ya fallecido, por lo que contar con esta información 
organizada y disponible en un medio electrónico implica tener al alcance datos que ya son imposibles de recuperar.

- Además, de ser posible, se registran los nombres de todas las personas involucradas en la elaboración del textil, por lo que surge su importancia como directorio y referencia de diversas asociaciones que se encuentran a lo largo del país.

Por otra parte, es útil para la elaboración de las cédulas que documentan las piezas integrantes de una exposición. En el caso de la CDI, se montan exposiciones temporales en muchas de las sedes nacionales e internacionales que integran el bagaje de difusión cultural de esta institución gubernamental, o de forma permanente en el Museo Indígena de la colonia Peralvillo. Por mencionar la más reciente, se realizó la exposición México megadiverso: culturas indígenas contemporáneas con gran éxito en el aeropuerto de la Ciudad de México.

Otro factor importante de la organización documental de los textiles es que permite generar plataformas, crear marcas y brindar trabajo a diferentes sectores de la sociedad, así como la colaboración de indígenas con diseñadores. A continuación, se mostrarán ejemplos de cada uno de ellos.

Amanoarte es una plataforma para mujeres indígenas y diseñadoras que impulsan sus proyectos. A través de este medio pueden dar a conocer sus creaciones. El objetivo principal es el apoyo a la mujer indígena mexicana por medio de la difusión su arte y legado, para que logren ser emprendedoras y autosustentables sin necesidad de salir de su comunidad, y bajo el reglamento de un comercio justo (Daniela, 2015).

Marcas y diseñadores como María Patrona recientemente han ganado múltiples premios por su compromiso con la moda mexicana a través del reconocimiento del textil indígena. La marca María Patrona posee la Fundación María Patrona, la cual se basa en promover y motivar a los productores 
artesanales para seguir creando y transmitiendo sus conocimientos en pro de la preservación de las tradiciones artísticas mexicanas; además se encarga de difundirlas y dar un porcentaje del valor de cada producto, el cual se asigna al sector artesanal para proyectos de educación (Daniela, 2015).

La Asociación Mexicana de Arte y Cultura Popular (AMACUP) es una sociedad civil sin fines de lucro que realiza acciones tendientes a la recuperación del patrimonio cultural vertido en la indumentaria de diversos estados, por ejemplo Oaxaca, considerado un importante estado productor de textiles.

El Fondo Nacional para el Fomento de las Artesanías (Fonart) es un fideicomiso público del gobierno federal que promueve la actividad artesanal del país y contribuye al desarrollo humano, social y económico de los artesanos y sus familias; además, ayuda a difundir el patrimonio cultural de México. Por otra parte, otorga apoyos para capacitación y producción, impulsa el comercio y organiza ferias, exposiciones y concursos de arte popular (Súper usuario, 2016).

La marca Lydia Lavín agrupa experiencias centradas en la riqueza cultural y textil de México. Desde su creación en 2005, la marca se ha distinguido por su cercana colaboración con artesanos. Esta propuesta ha sido llevada a las más importantes plataformas de moda en el país como Sapica, Fashion Week México, Intermoda y el Mercedes Benz Fashion Week México (Lavín, 2016).

Fábrica Social es una empresa conformada por una organización que impulsa el desarrollo de las capacidades de mujeres artesanas textiles a través de una escuela rural itinerante que imparte talleres en diseño, organización, administración y comercio justo a mujeres indígenas de México (Hello DF, 2016).

En cada uno de los ejemplos se contó con la información necesaria para el empoderamiento de estas comunidades. 


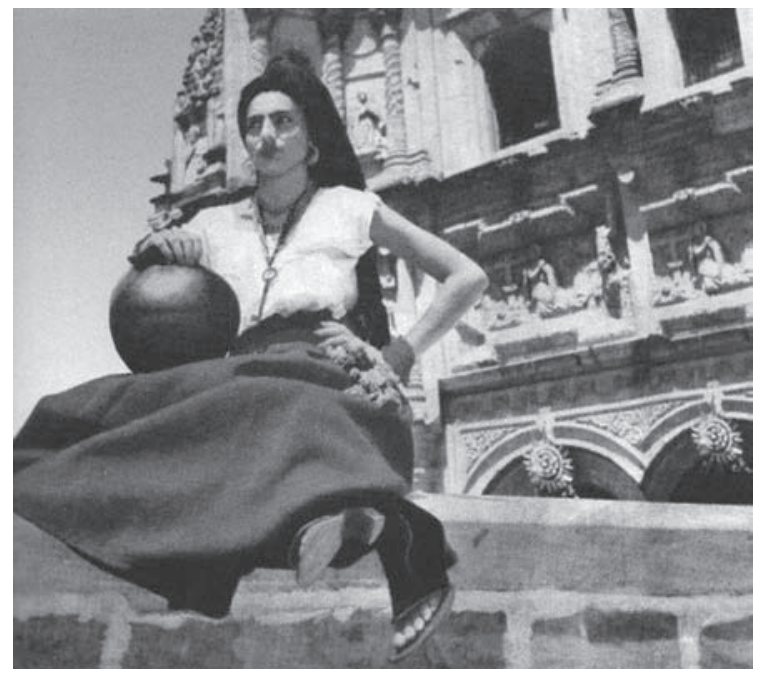

Mujer zapoteca del Valle de Mitla con sus "cactles" o "cáciles", calzado que sólo se usa durante las fiestas y las procesiones.

Fotografía 34C de Nicolas Johnson, 2002. En Claude Stresser-Péan (2012).

Actualmente, son muchos los foros de difusión de la industria textil mexicana: en el Festival Cervantino, en Guanajuato, se montó la exposición Arte Popular Poblano, Pasado y Presente. En ella, se mostraba parte de la colección del Museo Santa Rosa, con artesanías y piezas que resguarda del siglo XVIII y xIx. En una sección se encontraban los textiles más representativos de la zona: telares de cintura de Cuetzalan, indumentaria de mujeres de Hueyapan, San Pablito Pahuatlán, Altepexi, San Gabriel Chilac; éstas son algunas de las regiones poblanas exhibidas en cuadros y representaciones en maniquíes que muestran la belleza estética que poseemos (Maka México, 2016).

La exposición de Fomento Banamex titulada Indumentaria y moda en México: 1940-2015 presentó un recorrido de 75 años de historia de la moda e indumentaria mexicanas que conjuntó el diseño y el arte popular (Fomento Cultural Banamex, 2016). 
Una parte fundamental son los concursos y certámenes que promueven la creación de nuevos diseños, los cuales inclusive han dado un giro a la visión de competencia de los creadores, pues entre los artesanos han aparecido firmas para identificar su pieza dentro del mercado.

Además, desde hace tres años se organiza la Expo de los Pueblos Indígenas en las instalaciones de Expo Reforma, donde se reúne el trabajo de los artesanos integrantes de los diversos programas de apoyo que dirige y coordina la CDI. Estos grupos artesanales tienen como principal forma de sustento la elaboración de textiles, por lo que producen una cantidad considerable para la venta en centros turísticos y forman asociaciones que respaldan el trabajo indígena. Como parte del apoyo para seguir desarrollando sus técnicas, la CDI promueve estos espacios como medios para que los artesanos establezcan vínculos comerciales nacionales e internacionales para sus productos. En este magno evento, se pueden conocer y adquirir textiles, cestería, juguetes, mezcales, entre otros productos de más de 127 asociaciones indígenas que promueven sus creaciones; además, se presenta una degustación gastronómica de las regiones, se comparten conocimientos de medicina tradicional y se difunde la cultura indígena con una serie de presentaciones de música, danza y talleres (CDI, 2016b).

La importancia de las cooperativas radica en que además de sus fines empresariales de obtención de ganancias, se manejan intereses de carácter colectivo que mejoran la calidad de vida de sus miembros. Así, se tienen asociaciones como Tejedoras Triquis de Yosoyuxi de Santiago Juxtlahuaca, Oaxaca; Mujeres Conservando Raíces de Hueyapan, Puebla; Las Orquídeas de Xochistlahuaca, Guerrero y Esperanza Artesanal de San Bartolo Tutotepec, Hidalgo, por mencionar algunas sociedades respaldadas por la CDI que forman parte del catálogo de sociedades constituidas. Estas asociaciones ya han recibido 
apoyo del Fondo Nacional de Atención a Comunidades Indígenas, además de que cuentan con su registro ante Hacienda y el Instituto Mexicano de la Propiedad Intelectual.

Como parte de este esfuerzo conjunto se creó la marca registrada Manos Indígenas, Calidad Mexicana para respaldar los productos indígenas con esta marca que garantiza la calidad de los productos.

No es de extrañarse que sean los extranjeros los que valoren más el trabajo artesanal indígena de México; se pueden encontrar diversas páginas internacionales de Internet que difunden la venta de textiles y describen con una gran precisión y detalle cada uno de los aspectos de las piezas para documentar sus productos; estas cédulas de información tienen un gran valor al obtenerse de fuentes primarias como las entrevistas directas a los artesanos creadores de las prendas.

\section{Conclusiones}

La intención de este trabajo es la de compartir la importancia de documentar y organizar los textiles indígenas, ya que representan un documento ilimitado de la memoria de un pueblo indígena, pero, sobre todo, representan un documento que contiene información de valor trascendental para la memoria de la humanidad.

Los ejemplos anteriores de la labor de promoción en el sector textil representan el trabajo de diseñadores mexicanos, escritores y blogueros que mantienen viva la cultura como dignos representantes de la moda mexicana. La información, en todos los casos, les permite a los pueblos indígenas de nuestro país mejorar su situación social y económica y, por ende, el desarrollo de su comunidad.

Para concretar, es necesario enaltecer y revalorar el textil indígena como un documento al alcance de todos para que 
cuando sea adquirido por un consumidor no sólo lo adquiera por su valor estético, sino con el conocimiento de toda la información histórica, antropológica y social que engloba esta prenda además de concientizar que está adquiriendo una parte del alma del artesano y, más aún, un pedazo de historia de la nación mexicana.

El sello de Hecho en México nunca se verá mejor respaldado que con el trabajo de indígenas satisfechos de poder vender su creación a consumidores conocedores del valor de su trabajo.

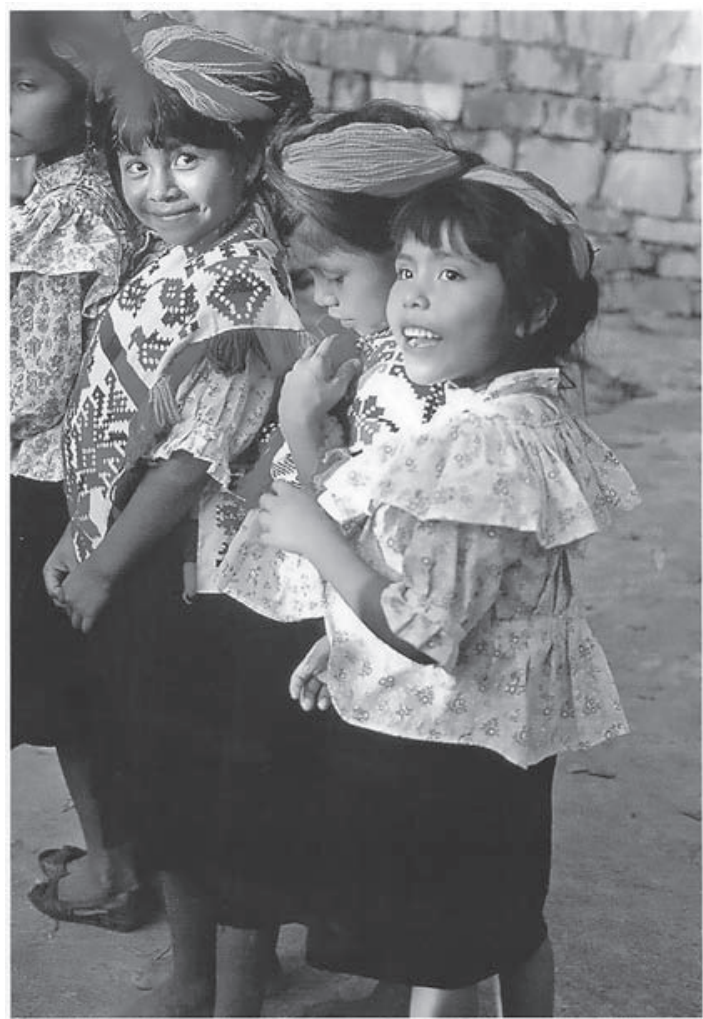

Niñas huastecas de Paytzen, San Antonio, San Luis Potosí.

Fotografía 30C de Claude Stresser-Péan. Fuente: Claude Stresser-Péan (2012). 


\section{Bibliografía}

Comisión Nacional para el Desarrollo de los Pueblos Indígenas (2016a). ¿Qué hacemos? Disponible el 20 de septiembre de 2016 en: http://www.gob.mx/cdi/que-hacemos.

(2016b). Se realiza la expo de los pueblos indigenas 2015. Disponible el 28 de septiembre de 2015 en: http://www.gob.mx/ cdi/prensa/se-realiza-la-expo-de-los-pueblos-indigenas-2015cdi?idiom $=$ es.

(2014). Arte y memoria indígena de México: el acervo de la Comisión Nacional para el Desarrollo de los Pueblos Indígenas. México: CDI.

Daniela (2015). Fashion Blog México. Entrada de blog disponible el 28 de septiembre de 2016 en: http://fashionblogmexico.com/ textiles-indigenas-en-la-moda-contemporanea/.

Fomento Cultural banamex (2016). Indumentaria y moda en México. 1940-2015. Disponible el 28 de septiembre de 2016 en: http:// fomentoculturalbanamex.org/noticias/indumentaria-y-moda-en-mexico-1940-2015/.

Hello D.F. (2016). "Fábrica social al rescate de las mujeres indígenas de nuestro país". Entrada de blog disponible el 28 de septiembre de 2016 en: http://hellodf.com/fabricasocial-al-rescate-de-las-mujeres-indigenas-de-nuestro-pais-mexico-fairtrade/.

Instituto Nacional de Estadística y Geografía (2004). La población indígena en México. Disponible el 22 de septiembre de 2016 en: http://inegi.org.mx/prod_serv/contenidos/espanol/bvinegi/productos/censos/poblacion/poblacion_indigena/Pob_Ind_Mex.pdf.

Johnson, K. (2015). Saberes enlazados: la obra de Irmgard Weitlanear Johnson. México: Artes de México.

Lavín, L. (2016). Trayectoria. Entrada de blog disponible el 28 de septiembre de 2016 en: https://lydialavin.com/. 
Maka México (2016). "Textiles indígenas incorporados a la moda contemporánea". Entrada de blog disponible el 28 de septiembre de 2016 en: https://makamexico.com/blog/textiles-indigenas-incorporados-a-la-moda-contemporanea.html.

Marín de Paalen, I. (1974). Historia general del arte mexicano: etnoartesanías y arte popular. México: Hermes.

Stresser-Péan, C. (2012). De la vestimenta y los hombres: una perspectiva histórica de la indumentaria indígena en México. MéXico: FCE.

Súper Usuario (2016). “QQué es el FONART?” Disponible el 28 septiembre de 2016 en: https://www.fonart.gob.mx/web/index.php/conoce-fonart/que-es-fonart.

Tu interfaz de negocios (2013). "La industria textil en México: hacia su recuperación”. Disponible el 25 de septiembre de 2016 en: http:// www.tuinterfaz.mx/articulos/10/77/la-industria-textil-en-mexico-hacia-su-recuperacion/.

Velasco Rodríguez, G.J. (1995). Origen del textil en Mesoamérica. México: IPN. 


\section{El consumidor ante los productos y servicios de contenidos audiovisuales}

Francisco Esquivel del Reyo

Infosferas, México

\section{INTRODUCCIÓN}

71 consumidor de productos y servicios de contenidos audiovisuales ha evolucionado en el contexto contemporáneo de una sociedad mediática y globalizada. Considerando las características de las diferentes generaciones que coexisten actualmente, se analiza la interacción que el mercado de consumo tiene con los recursos y servicios audiovisuales.

Una de las salidas profesionales para los bibliotecarios y documentalistas es el sector corporativo, desde la industria farmacéutica, hasta los medios de comunicación. En este sector, la incorporación de los profesionales de la información se da con éxito y marca una diferencia significativa en los sectores productivos y económicos, además de que genera la apertura de más fuentes de empleo, oportunidades para prácticas profesionales de los estudiantes en las carreras de ciencias de la información y documentación, e información para la investigación en estas disciplinas. 
EL CONSUMIDOR

Partiendo de las tendencias que se han presentado durante las primeras décadas del siglo actual, los recursos y servicios audiovisuales para los consumidores han evolucionado en diferentes formatos y plataformas. Iniciamos por definir al consumidor. Para ello, revisamos la definición de la Real Academia Española: "Consumidor, ra. 1. adj. Que consume. 2. m. y f. Persona que adquiere productos de consumo o utiliza ciertos servicios".

Para ampliar este concepto, debemos considerar también el comportamiento del consumidor, así como observar y conocer la forma en que compran los consumidores finales, es decir los individuos o familias que obtienen bienes y servicios, en este caso, productos audiovisuales para consumo personal. De acuerdo con lo que señalan Kotler y Gary (2007: 7), "Un mercado es el conjunto de compradores reales y potenciales de un producto. Tales compradores comparten una necesidad o un deseo en particular, el cual puede satisfacerse mediante relaciones de intercambio".

Este mercado de consumo se ha vuelto complejo, y nuestro contexto actual mantiene diferentes generaciones coexistiendo e interactuando en los sectores productivos y económicos, que generan datos que pueden ser de gran utilidad para la solución de problemas complejos respecto al uso de información.

A continuación, se presenta una infografía que forma parte de un artículo titulado "Marketing, insights y generaciones”. El texto señala lo siguiente:

Mientras las empresas buscan formas creativas de comunicarse con sus clientes y diferentes segmentos, olvidan algunas veces la importancia de los llamados "INSIGHTS" del consumidor. Los insights pueden ser definidos como vivencias con las que cuentan las personas 
y a través de las cuales se pueden activar "Experiencias" con la comunicación creativa de la empresa y desarrollar así la creación de vínculos, participación, impacto e involucramiento con las diferentes audiencias, parte muy importante en el proceso de generación de campañas de comunicación y estrategias de marketing enfocadas a motivar a usuarios entendiendo sus insights y generaciones a las que pertenecen (2016).

Las nuevas generaciones son protagonistas de los cambios:

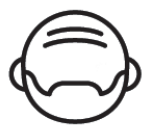

Baby Boomers $22 \%$

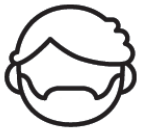

$\mathrm{X}$ $18 \%$

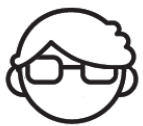

Millenials (Y)

$42 \%$

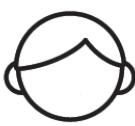

$\mathrm{Z}$ $\mathbf{2 2 \%}$

\begin{tabular}{|c|c|c|c|c|}
\hline & Análogos & Inmigrantes & \multicolumn{2}{|c|}{ Nativos Digitales (59\%) } \\
\hline Año & $\begin{array}{c}\text { 1946-1964 } \\
\text { (49-57 años) }\end{array}$ & $\begin{array}{c}1965-1979 \\
\text { (35-48 años) }\end{array}$ & $\begin{array}{c}1980-1999 \\
(15-34 \text { años })\end{array}$ & $\begin{array}{c}2000 \\
\text { (0-14 años) }\end{array}$ \\
\hline Hitos & $\begin{array}{l}\text { Guerra fría, } \\
\text { Woodstock }\end{array}$ & $\begin{array}{l}\text { Muro de Berlín, } \\
\text { Early mobile }\end{array}$ & $\begin{array}{c}\text { Globalización, } \\
9 / 11\end{array}$ & $\begin{array}{c}\text { Calentamiento } \\
\text { global }\end{array}$ \\
\hline Comm. & & & & \\
\hline Shop & $\begin{array}{c}\text { Son reflexivos } \\
\text { y lentos }\end{array}$ & $\begin{array}{c}\text { Son reflexivos } \\
\text { y lentos }\end{array}$ & $\begin{array}{l}\text { Toman decisio- } \\
\text { nes inmediatas }\end{array}$ & $\begin{array}{l}\text { Inmediatez y } \\
\text { Switch }\end{array}$ \\
\hline Motivación & $\begin{array}{c}\text { Orden } \\
\text { Estructura }\end{array}$ & $\begin{array}{l}\text { Logros } \\
\text { Metas }\end{array}$ & $\begin{array}{c}\text { Socialización } \\
\text { Disfrute }\end{array}$ & $\begin{array}{c}\text { Contribución } \\
\text { Movilidad }\end{array}$ \\
\hline
\end{tabular}

Base total: 6,750 casos; 6,834 Exp. 
La dinámica de nuestro tiempo nos obliga a ver más allá y buscar formas de colaboración multidisciplinaria. Es en este punto donde la experiencia de profesionistas de otras áreas (comunicación, mercadotecnia, sociología) nos puede aportar información valiosa para obtener una mayor comprensión de nuestro entorno y mejorar la participación con los diferentes tipos de consumidores de recursos y servicios de contenidos audiovisuales.

Tomando en consideración que el consumidor del siglo xxI tiene a su disposición una gama muy amplia de recursos y servicios de contenidos audiovisuales para obtener recreación, hacerse de información, educarse o formarse continuamente, revisemos a detalle estos aspectos:

\section{A. Recreación}

Actualmente, los medios de comunicación ofrecen servicios y recursos diseñados para diferentes plataformas: televisión abierta, televisión de paga, sitios web, aplicaciones para dispositivos móviles e incluso presentaciones en cine.

Como ejemplo reciente, podemos mencionar la transmisión de los juegos olímpicos de Río de Janeiro en el año 2016, cuando el consumidor tuvo acceso a canales de recursos audiovisuales de los eventos deportivos durante las transmisiones en vivo, y la oportunidad de escoger el video de su preferencia dentro de una videoteca en línea de la jornada olímpica del día, así como de los días previos. Lo anterior estuvo disponible desde la página web o la aplicación para dispositivos móviles de Claro Sports. ${ }^{10}$

Otro ejemplo son las cápsulas breves que la plataforma Twitter pone a disposición del consumidor gracias a la alianza que tiene con la National Football League (NFL), que permite

10 Canal de entretenimiento deportivo por televisión e Internet que transmite las 24 horas del día. Está disponible en Latinoamérica y es propiedad de América Móvil. 
a cada espectador compartir el contenido directamente desde sus redes sociales. Esta opción es parte del fenómeno actual de las dos o tres pantallas de que dispone un consumidor al momento de utilizar productos o servicios de contenidos audiovisuales. Así se modifica la dinámica, de solamente ser un espectador frente al televisor, a poder compartir en tiempo real segmentos en video del evento deportivo, así como agregar comentarios, en este caso por medio de las redes sociales. Lo que le agrada al consumidor respecto a esta nueva dinámica es:

- Poder participar con comentarios y likes.

- Compartir contenido en video por medio de redes sociales.

- Elegir lo que quiere ver, cómo lo quiere ver y a la hora que lo quiere on demand, y seguir la transmisión en segunda o tercera pantalla para revisar estadísticas, compartir memes, etcétera.

\section{El consumidor valora:}

- Costo. Paga por contenidos de calidad. El alto número de suscriptores de sistemas de contenidos de entretenimiento de pago en todo el mundo, y su crecimiento en diversas plataformas y servicios como Netflix, es una muestra de esta creciente tendencia.

- Accesibilidad. Tener la posibilidad de acceder a los sitios web para buscar la información y servicios que requiere, algunos de ellos personalizados por segmento de la población.

- Portabilidad. Tener la posibilidad de hacer uso de recursos o servicios desde diversos tipos de equipos, sobre todo dispositivos móviles.

Además de lo anterior, el consumidor del siglo xxi es diferente al que conocíamos o pretendíamos conocer en el siglo $\mathrm{xx}$, pues ha desarrollado competencias como: 
- Saber utilizar el hardware, el equipo en el que tiene instalado el software para recibir los recursos de entretenimiento; presenta un buen conocimiento del uso de los dispositivos móviles.

- Contar con un dominio de la plataforma en web; aprendió con el uso a buscar y recuperar contenidos, a programar y seleccionar los mismos.

- Poder realizar pagos electrónicos y efectuar trámites como buscar estados de cuenta.

\section{B. Información}

El consumidor actual tiene acceso a información en diferentes formatos como texto, audio, video, fotografías, mapas y realidad aumentada, durante las 24 horas del día, los siete días de la semana, a lo largo de todo el año, desde cualquier dispositivo. Conviene subrayar que esto es posible gracias al desarrollo de software que permite romper la barrera del idioma.

En cuanto a la información para resolver su día a día, la tiene a disposición casi de inmediato. Recordemos la forma antigua de llegar a una dirección dentro de cualquier ciudad, particularmente en la Cuidad de México: antes consultábamos la Guía Roji, un mapa de la ciudad con planos en forma de libro para llevarlo mientras caminabas, viajabas en transporte público o en el auto y que servía para ubicar la dirección; esto después de preguntar a un familiar, o en la calle, por la dirección requerida.

Ahora, para la misma situación, tenemos a nuestra disposición diversas opciones que en tiempo real nos ofrecen información tan completa como:

- Personalizar la ruta.

- Ubicación geográfica en mapa.

- Datos del tráfico vehicular. 
- Tiempo estimado de traslado.

- Rutas alternas.

Estos servicios permiten, entre otras posibilidades, tomar decisiones en tiempo real y corregir la ruta sobre la marcha de acuerdo con las incidencias de tráfico vial que se presentan. El reporte de tráfico en la radio, que era utilizado frecuentemente como primera referencia a finales del siglo $\mathrm{xx}$ e inicio del presente siglo actualmente es una fuente de información complementaria, porque se usa como primera opción los datos de las aplicaciones móviles como Waze. Lo que al consumidor le gusta de esta nueva forma de uso de la información es:

- Construir comunidad. La posibilidad de aportar (cultura colaborativa), compartir información de los accidentes viales, cámaras de seguridad y baches. Actualizar información en las entradas de Wikipedia y recomendar hospedaje, por mencionar algunos ejemplos; evaluar y recomendar servicios de consumo colaborativo como Bla, bla, Car y calificar servicios como uber o Cabify.

- Compartir en redes sociales. Beneficiar a la comunidad compartiendo información de las que consideran mejores opciones o emitir valoración de productos y servicios.

- Generar ahorro en tiempo, dinero y esfuerzo para beneficio personal y de la comunidad.

El consumidor valora los siguientes aspectos:

- Rapidez y utilidad. La dinámica de la vida urbana demanda información precisa y expedita, que aporte algo útil, para la toma de decisiones.

- Accesibilidad. Tener la posibilidad de acceder a los sitios web para buscar la información y servicios que requieren, algunos de ellos personalizados por segmento de la población. 
- Usabilidad. La facilidad de uso de una plataforma es un punto esencial, ya que mucha de la información es de primera mano; por ejemplo, una señora que busca un plomero, o un taxista que busca la dirección donde recoger a su pasajero. Éstos son tan sólo dos de los millones de usos que tienen en nuestra vida cotidiana.

- Claridad en el precio y posibilidad de calificar el servicio. Para productos y servicios, las tendencias a nivel mundial nos enseñan que las personas requieren información clara de los costos y tener la capacidad de evaluar los servicios o a los prestadores de los mismos. Incluso valoran la posibilidad de evaluar la usabilidad de las plataformas.

Además de lo anterior, el consumidor de productos y servicios de contenidos audiovisuales del siglo xxI es diferente al que se conocía o pretendía conocer en el siglo xx por presentar diversas competencias adquiridas. Es un consumidor sofisticado.

\section{Educación y formación continua}

La revolución educativa que estamos viviendo actualmente permite que mucha información valiosa para generar conocimiento, que antes estaba concentrada en las instituciones educativas, esté disponible para aquellas personas que la necesiten a través de repositorios de acceso abierto en formatos digitales tan diversos como videos de YouTube, libros en PDF descargables de páginas web, tutoriales y cursos en línea. Asimismo, la tendencia de muchos profesionales y expertos de compartir conocimiento de forma gratuita y a distancia se suma a la consciencia de las instituciones públicas para compartir a toda la población los productos académicos o de investigación. Al mismo tiempo, los entornos personales de aprendizaje permiten cada vez más perfilar y especializar a cada persona de acuerdo con su vocación y ritmo de aprendizaje. 
Ciertamente, vivimos en un momento histórico en el que todas las instituciones, incluyendo las educativas, se ven rebasadas por el contexto mundial y se enfrentan a nuevos paradigmas que atender de forma inmediata; una de ellas es reducir la brecha entre el mundo académico y las necesidades del mercado laboral.

Es en este contexto que los consumidores aprovechan la creciente y cada vez más variada oferta de la educación mediada por tecnologías, que incluye los productos y servicios de contenidos audiovisuales, para complementar su educación formal, diversificarse ante las condiciones de empleabilidad en el cambiante mercado laboral, y dar curso a su vocación formándose de manera autónoma en temas de interés personal tan diversos como plomería, guitarra, yoga, fotografía, cocina y hasta impresión de objetos en 3D.

Sea para recibir un ingreso extra o para lograr un beneficio social, definitivamente vivimos una nueva etapa de la cultura maker en la que el "hágalo usted mismo" se nutre de los beneficios de las Tecnologías de la Información y Comunicación y de la visión de las generaciones Y y Z que prefieren entornos de estudio y trabajo colaborativos, además de que son generosos al compartir ideas, información y conocimiento. A todo lo anterior, se suma el hecho de que el mercado laboral busca competencias que van más allá de los títulos académicos. En definitiva, el consumidor valora:

- Un recurso o servicio de información que se adapte a su estilo de vida, disponible las 24 horas, los siete días de la semana y los 365 días del año.

- A lo anterior se suma que esté disponible de manera remota porque el teletrabajo y la tele-educación ya son estilos de vida.

- Contar con un interlocutor en tiempo real, y es mejor si éste puede comunicarse en más de un idioma. 
El consumidor ahora presenta las siguientes competencias adquiridas:

- Sabe crear alertas, configurar plataformas y sistemas para hacerse de información filtrada, publicada o por publicarse. Los más avezados se dirigen a las fuentes primarias; también usan las redes sociales para crear y administrar grupos de especialistas que generan información y conocimiento fuera de las estructuras establecidas en las instituciones académicas.

- Comparte información desde las plataformas.

- Aporta experiencia de uso o de compra.

- Evalúa servicios.

- Sabe usar buscadores y operar gestores de referencias.

- Sabe trabajar con grandes cantidades de datos.

- Genera tutoriales en YouTube, publica en blogs, crea y diseña su propia página web.

Todo esto es suficiente para vislumbrar el reto que plantea a los profesionales de la información atender a un consumidor tan sofisticado. Pero aún viene lo mejor, porque en la Era de David (David contra Goliat), en la que los pequeños pueden dar batalla a los grandes, un porcentaje de estos consumidores, los creativos, los divergentes, los impulsivos, ya han empezado a crear ellos mismos sus propios contenidos y se han convertido en generadores de productos y servicios de contenidos audiovisuales.

\section{Prosumidores}

El prosumidor es un ente primordialmente creador que vive en los ecosistemas Wiki (Wikipedia) y maker (cultura maker); es un investigador nato, que lo mismo se interna en los textos 
más novedosos de su disciplina que aprende de producción de video, redacción, programación, transferencia de archivos, etcétera. Colabora, comparte, aprende creando y es generoso con el conocimiento adquirido.

Toffler (1980: 106) en su libro La tercera ola define a este nuevo actor señalando:

El prosumidor abandona la faceta pasiva para convertirse en generador de contenidos y creador de ideas y opiniones que ejercen influencia a la comunidad de compradores de una marca o un producto, lo cual, genera cambios: Las marcas concebían a los consumidores como masas homogéneas cuya función era consumir. En la Web 2.0 y con la proliferación de las comunidades interactivas, las marcas no sólo debían convencer a los consumidores, además, tenían que escucharlos.

Como resultado, el consumidor se encuentra entrenado para usar el software y tiene la posibilidad de compartir contenido de todo tipo en la web, lo que genera una explosión de documentos que plantea un pendiente en la curaduría de los mismos, su organización y preservación. ¿Qué es lo valioso?, ¿para quién?, ¿es un documento con información histórica? Son tantos los planteamientos que la mirada con ojos de siglo xx puede generar una miopía documental, y seguramente las generaciones del siglo xxi, desde su visión, entenderán de forma distinta y plantearán soluciones, si son necesarias, desde su particular forma de ver y construir el mundo.

\section{INFLUENCERS}

Este anglicismo se utiliza para definir a las personas que pueden influir en una decisión de consumo de algún producto o servcio. De acuerdo con la definición de Wikipedia: 
El marketing influyente es una forma de marketing que ha surgido a partir de una variedad de prácticas y estudios recientes, en la que se enfocan en las claves específicas de los individuos más que en el mercado objetivo en su conjunto. Identifica a las personas que tienen influencia sobre los compradores potenciales y las actividades de marketing orientadas en torno a estas personas influyentes.

Por tanto, el abanico de las personas influyentes es variado de acuerdo con cada generación, como se detalla en la tabla 1.

Algunos ejemplos de este tipo de personas influyentes, que tienen en la actualidad mucha visibilidad en las generaciones jóvenes de México, son los youtubers; pongamos por caso a Yuya, Werevertomorro y recientemente Chumel Torres y Franco Escamilla. Entre los extranjeros de habla hispana, sin duda esta Germán Garmendia.

\section{OTRAS TENDENCIAS Y FENÓMENOS ACTUALES}

Durante la transición que se experimenta a nuestro alrededor, mientras avanzamos en el presente siglo, son varias las tendencias y los fenómenos que vivimos diariamente. Algunos de ellos los adoptamos de forma natural y para otros tenemos reservas. En la tabla 2 se observan algunas de las tendencias y los fenómenos implicados en la relación entre los productos y servicios de contenidos audiovisuales, y los consumidores.

Cada una de estas tendencias y fenómenos se van adaptando y mutan. Es importante conocer su existencia y obtener datos sobre la relación con el consumidor para mejorar los servicios y productos de contenido audiovisual. 


\begin{tabular}{|c|c|c|c|}
\hline Generación & Tipo de influencer & Medio & Cobertura \\
\hline Baby Boomers & $\begin{array}{c}\text { Conductores de } \\
\text { noticieros y programas de } \\
\text { entretenimiento }\end{array}$ & $\begin{array}{l}\text { Televisión y } \\
\text { radio oficiales } \\
\text { y cadenas } \\
\text { comerciales }\end{array}$ & $\begin{array}{c}\text { Regional o } \\
\text { nacional }\end{array}$ \\
\hline Generación $\mathbf{X}$ & $\begin{array}{c}\text { Conductores de } \\
\text { noticieros y programas de } \\
\text { entretenimiento }\end{array}$ & $\begin{array}{l}\text { Televisión y radio } \\
\text { oficiales, cadenas } \\
\text { comerciales } \\
\text { y medios } \\
\text { alternativos }\end{array}$ & $\begin{array}{c}\text { Regional o } \\
\text { nacional }\end{array}$ \\
\hline Generación Y & $\begin{array}{c}\text { Personalidades, artistas } \\
\text { conductores de noticieros } \\
\text { y programas de } \\
\text { entretenimiento, youtubers, } \\
\text { blogueros }\end{array}$ & $\begin{array}{l}\text { Televisión y } \\
\text { radio migradas } \\
\text { a Web, canales } \\
\text { nativos en web } \\
\text { alternativos }\end{array}$ & $\begin{array}{c}\text { Internacional } \\
\text { o nacional }\end{array}$ \\
\hline Generación Z & $\begin{array}{l}\text { Youtubers, blogueros } \\
\text { y programas de } \\
\text { entretenimiento }\end{array}$ & $\begin{array}{c}\text { Canales en } \\
\text { web, cadenas } \\
\text { comerciales, } \\
\text { alternativos, } \\
\text { de amistades y } \\
\text { propios }\end{array}$ & $\begin{array}{c}\text { Internacional } \\
\text { o nacional }\end{array}$ \\
\hline
\end{tabular}

Tabla 1. Tipos de influencer por generación.

\begin{tabular}{|c|c|c|c|}
\hline Culturales & Consumo & Revolución educativa & TICS \\
\hline $\begin{array}{l}\text { - Youtubers } \\
\text { - Nuevos medios } \\
\text { de comunicación y } \\
\text { entretenimiento } \\
\text { - Narrativas } \\
\text { transmedia } \\
\text { - Investigación } \\
\text { aplicada }\end{array}$ & $\begin{array}{l}\text { - Consorcios } \\
\text { - Consumo } \\
\text { colaborativo } \\
\text { personal (Bla bla } \\
\text { Car) } \\
\text { - Espacios } \\
\text { coworking } \\
\text { - Espacios colab's }\end{array}$ & $\begin{array}{l}\text { - Inteligencias múltiples } \\
\text { - Educación a distancia } \\
\text { - Learning commons } \\
\text { - Entornos personales de } \\
\text { aprendizaje } \\
\text { - Universidades } \\
\text { corporativas }\end{array}$ & $\begin{array}{l}\text { - Web } 2.0 \\
\text { - Dispositivos } \\
\text { móviles } \\
\text { - Realidad } \\
\text { aumentada } \\
\text { - Internet } \\
\text { - Big Data }\end{array}$ \\
\hline
\end{tabular}

Tabla 2. Tendencias en el siglo xxI. 


\section{Conclusiones}

Vivimos un momento histórico, propio del cambio en el que las normas establecidas y operantes en el siglo anterior se ven rebasadas por el contexto actual. En definitiva, es indispensable obtener más datos sobre los consumidores de productos y servicios audiovisuales, su relación con los modelos de gestión y la administración de los mismos. Los profesionales de la información tenemos una oportunidad para aprender y aportar valor desde nuestra disciplina a los sectores productivos y económicos.

Respecto a los consumidores de contenidos audiovisuales, podemos mencionar lo siguiente:

- Existen diversos perfiles de consumidores.

- Acostumbran compartir, construir comunidad, crear y colaborar.

- Están aumentando lo prosumidores y algunos de ellos son influencers.

Respecto a los profesionales de la información, podemos comentar:

- Como salida profesional, existe la opción de colaborar desde nuestras instituciones en el desarrollo de servicios y productos de contenido audiovisual para los consumidores con conocimiento de sus características, intereses y estilos de vida.

- Otra salida profesional es la especialización en la organización documental de servicios y productos de contenido audiovisual tanto para el sector público como para la iniciativa privada. 


\section{Bibliografía}

Del Alcázar, Ponce Juan Pablo (2016). "Insights y generaciones impactan a nuestras marcas y la forma en que las gestionamos". Formación Gerencial Internacional. Disponible en: http://blog. formaciongerencial.com/2016/01/08/insightsygeneraciones/.

Kotler, Philip y Gary Armstrong (2007). Marketing versión para Latinoamérica. México: Pearson. Disponible en: https://uvgcancun.files.wordpress.com/2016/03/kottler-phillip-armstrong-gary-marketing-versic3b3n-para-latinoamc3a9rica.pdf.

Toffler, Alvin (1980). La tercera ola. México: Plaza y Janés. Disponible en: https://cruceshernandezguerra.wikispaces.com/file/ view/La+tercera+ola.pdf. 


\section{La organización documental en las industrias creativas}




\title{
La organización documental en las industrias creativas
}

\author{
Catalina Naumis Peña \\ Instituto de Investigaciones Bibliotecológicas y de la Información \\ UNAM
}

Ta diversificación de los soportes de información, una 1 característica presente desde el siglo $\mathrm{xx}$, se manifiesta entre otros aspectos en las industrias creativas debido al valor económico que han ido adquiriendo y a las nuevas tecnologías que hacen posible crear sistemas de visibilidad. Como consecuencia, surge la necesidad de conocerlas, analizarlas y organizarlas para plasmar sus contenidos en los sistemas de información con la finalidad de recuperarlos para los usuarios finales.

La primera ocasión en que se discutió acerca de la economía basada en la creatividad fue en 1998 en un reporte oficial del Departamento de Cultura, Medios y Deportes del Reino Unido. En éste, se especificaba que las industrias creativas son "aquellas que tienen su origen en la creatividad, habilidades y talento individual y cuyo potencial se extiende a través de la generación y exportación de la propiedad intelectual" (Higgs et al., 2008: 22, apud Sava, 2016: 403). 
Esta definición no ha estado exenta de críticas por diversas razones, como lo explica Diana Sava, investigadora de la Facultad de Ciencias Económicas de la Universidad de Oradea, Rumania. El señalamiento implica, por ejemplo, que la definición del término tal como se presentó en 1998 abarcaría industrias como la farmacéutica o la ingeniería de negocios (Newbigin, 2010: 23, apud Sava, 2016: 403).

Con el ánimo de clarificar, el propio Departamento de Cultura, Medios y Deportes del Reino Unido identificó trece sectores económico-culturales con actividades que podrían estar comprendidas bajo este campo (Newbigin, 2010: 23). A saber, incluyó:

- Arquitectura.

- Artes representacionales.

- Artesanía.

- Cine.

- Creación de software.

- Diseño de modas.

- Diseño.

- Edición.

- Mercado de arte y antigüedades.

- Música.

- Publicidad.

- Radio.

- Televisión.

- Videojuegos.

A partir de esta distinción realizada en el Reino Unido, las economías de diferentes países adoptaron el término y su conceptualización. A su vez, realizaron las adaptaciones necesarias para ajustarlo hasta incluir expresiones creativas de diversos sectores industriales que tienen mayor peso y participación en la construcción del Producto Interno Bruto, 
entre otras variables. Es decir, el rol de las industrias creativas ha crecido hasta convertirse en una parte importante del sistema económico.

Sava asegura que, desde una perspectiva semántica, la economía creativa está conectada con otros términos como economía del conocimiento, economía de la información, industrias creativas e industrias culturales. En este sentido, emerge un espacio donde estos y otros conceptos se vinculan con el campo de la investigación bibliotecológica.

Como ha sido profusamente documentado, es reconocido el paradigma de las industrias culturales, particularmente desde la investigación social, tal como ocurre en los estudios antropológicos, sociológicos y de la comunicación, por ejemplo. Esto sucede ya desde hace varias décadas. Al respecto, hay que tomar en consideración que para diferentes organismos internacionales relacionados con el patrimonio de la humanidad, las industrias culturales han quedado circunscritas al ámbito de las industrias creativas; por ejemplo, para la Unesco y la Conferencia sobre Comercio y Desarrollo de las Naciones Unidas (UNCTAD por sus siglas en inglés).

En los reportes de la Unesco, las industrias culturales son presentadas como una sección o parte de las industrias creativas, y son reconocidas como formas de producción y consumo cultural, que en esencia tienen componentes simbólicos o elementos expresivos, con independencia del valor económico que puedan aportar (Unesco, 2013: 20). En un esfuerzo por categorizar o clasificar las industrias creativas, las organizaciones relacionadas con ellas han tomado en consideración diferentes criterios:

- El Departamento de Cultura, Medios y Deportes del Reino Unido ha tomado en consideración el criterio más amplio tal como ya se comentó al inicio de esta presentación. 
- La Comisión Europea ha realizado la clasificación tomando en cuenta si las industrias creativas se dedican esencialmente al arte (como las artes visuales y las artes dramáticas) o si tienen conexión con los medios de comunicación. Adicionalmente, han distinguido industrias y actividades creativas que se emplean en sectores no necesariamente culturales (diseño, arquitectura y publicidad).

- La Unesco clasifica las industrias creativas en dos ramas. La primera considera aquellas que esencialmente están conectadas con alguna expresión cultural (museos, galerías, bibliotecas, festivales, artes visuales, artes dramáticas, televisión y radio, cine y video, edición, fotografía e interactive media). La segunda categoría apela a las industrias creativas que van más allá de lo cultural a lo comercial como son la música, publicidad, arquitectura, artes gráficas y desarrollo de software).

- La World Intellectual Property Organization toma en cuenta como criterio la relevancia de la gestión de derechos autorales. Las clasifica en:

- Industrias creativas dependientes del copyright: publicidad, música, artes dramáticas, cine, video, edición, software, televisión, artes visuales y gráficas.

- Industrias creativas parcialmente conectadas con el copyright: arquitectura, moda, diseño, juguetes.

- Industrias creativas interdependientes del copyright: equipos electrónicos de consumo, instrumentos musicales, equipo fotográfico.

El ámbito de las industrias creativas y culturales está en estudio y nuevas vertientes de investigación surgen a su alrededor. En contraste, la bibliotecología y los estudios de la información se han aproximado desde diferentes visiones que tocan los linderos del patrimonio bibliográfico y documental, lo mismo que la producción de software y, como se reflexionará 
en esta mesa, las artesanías, piezas museográficas, los fondos documentales cinematográficos y la producción audiovisual de la televisión presente en la web.

Sin duda, el incremento de información en las industrias creativas es un reto para la investigación bibliotecológica, dada la variedad de soportes y expresiones artísticas y tecnológicas que deben ser organizados para asegurar una recuperación del conocimiento y la información que contienen. Y todo ello, como bien destaca el conferencista doctor Trejo, con la "más escrupulosa neutralidad académica”. 


\section{Bibliografía}

Mietzner, Dana y Martin Kamprath (2013). "A competence Portfolio for Professionals in the Creative Industries". Creative and Innovation Management, 22 (3), 280-295.

Sava, Diana (2016). "Cultural and Creative Industries". Annals of the University of Oradea, Economic Science Series 25 (1), 402-409.

Unesco (2013). Creative Economy Report. Special Edition. Disponible el 6 de octubre de 2016 en: http://academy.ssc.undp.org/ GSSDAcademy/Upload/CER13_Report_web_optimized.pdf. 


\title{
Industrias creativas. Cultura, mercado y libertad en el entorno digital
}

\author{
Raúl Trejo Delarbre \\ Instituto de Investigaciones Sociales \\ UNAM
}

\begin{abstract}
ierto afán de corrección política, pero también de precisión analítica, ha puesto de moda el término industrias creativas para denominar a las que durante más de medio siglo consideramos como industrias culturales. No son exactamente idénticas, pero se parecen demasiado. Se ubican en entornos distintos, pero generan, aprovechan y ponen en circulación esencialmente lo mismo, es decir, mensajes y contenidos que alcanzan audiencias masivas. Se trata de actividades e instituciones dedicadas fundamentalmente al entretenimiento y la información, aunque con repercusiones distintas en cada uno de los paradigmas analíticos que está detrás de esas denominaciones.

Son industrias creativas, esencialmente, las que resultan del ingenio de las personas para producir mensajes y/o contenidos que tienen sentido en tanto son mostrados o difundidos entre núcleos amplios de la sociedad. Podríamos añadir que las industrias creativas se benefician de la reproductibilidad y propagación que permiten las tecnologías digitales. Aunque puede haber contenidos en formatos analógicos,
\end{abstract}


por lo general las industrias creativas son parte del nuevo entorno digital.

Entre las industrias creativas, se encuentran artes, medios y prácticas tradicionales como la literatura y la producción de libros, el cine y la televisión, la música y sus diversas formas de propagación, la publicidad y el diseño. Pero el término también comprende la creación de software y videojuegos, la prensa y la radio en línea, los videos y en general los contenidos que circulan por las redes digitales. Además, entre ellas se encuentran los museos, el turismo y diversas formas de organizar, satisfacer y mercantilizar el ocio en las sociedades contemporáneas.

MASIFICACIÓN Y REPRODUCCIÓN

EN LAS INDUSTRIAS CULTURALES

Muchas de esas expresiones artísticas y mediáticas no existían cuando en la segunda mitad de la década de los cuarenta (del siglo xx, por supuesto) los patriarcas de la Escuela de Frankfurt etiquetaron a las industrias culturales para subrayar el carácter masivo, los alcances sociales, la naturaleza mercantil y, sobre todo, los alcances ideológicos de los bienes de consumo que eran posibles gracias a la transmisión a distancia y la reproducción más o menos masiva de contenidos. El cine y la radio, además de la imprenta y, de manera muy incipiente, la televisión, conformaban ya una cultura de masas en donde las modas literarias y las maneras de vestir uniformaban a muchas personas de manera similar a la cohesión que asumían ante ideologías y preferencias políticas.

La propagación y creación intensa de contenidos en los medios de comunicación condujo a la denominación de "industrias culturales" para las actividades que multiplicaban 
la difusión de contenidos. Ese término reconocía tres rasgos esenciales. Por una parte, se encontraba el proceso industrial en serie, en el que se maquilaban tales contenidos. Se trataba de industrias, es decir, de negocios, que requerían de maquinaria o artefactos especializados tanto para reproducir un producto cultural (los ejemplares de un periódico, por ejemplo), como para esparcir a distancia un contenido (como sucede con las transmisiones radiofónicas); o para registrarlo con el propósito ulterior de reproducir copias de ese contenido (como hace la cámara de cine que registra imágenes para, una vez procesadas y editadas, ser mostradas por el proyector en la sala habilitada para ello).

Gracias a esos recursos se establecía, en un segundo momento, un proceso de comunicación. Del emisor al medio, de allí a una plataforma de transmisión (las ondas hertzianas, el kiosco de periódicos, la sala de cine) y, de ahí, a los receptores o públicos: así de sencillo, pero también así de vertical ha sido el proceso de la comunicación de masas. Aunque los patriarcas de Frankfrut no se inquietaron demasiado por ello porque les parecía evidente y quizá inevitable, ese proceso está singularizado por una transmisión autoritaria: unos cuantos difunden para muchos más. La comunicación de masas, podemos decir ahora, nunca es democrática. No es de masas sino para ellas.

El tercer rasgo de esa producción en masa de los mensajes comunicacionales es su degradación, que a final de cuentas implica el menoscabo de la originalidad y calidad de la cultura. Al ser concebida como una sucesión de productos para la industria cultural, o al ser convertida en tales productos, la cultura, en la concepción de aquellos pensadores de origen alemán, se degrada debido a la producción en masa. Sometida a las exigencias de la mercantilización, la cultura se convierte en industria del entretenimiento como 
tanto nos consta a quienes, en diferentes generaciones, crecimos con la televisión.

Determinada por los requerimientos del negocio y no por la creatividad sin sujeciones, la cultura resulta estandarizada y se produce en serie. La estética queda supeditada al consumo y las modas, y no necesariamente la calidad determina el éxito de la obra de arte o, de manera más modesta, del producto cultural. Las finanzas nunca son un buen criterio para determinar la relevancia de un producto de esa índole pero, imbricadas con las habitualmente veleidosas preferencias del público, muy frecuentemente condicionan contenidos y formas de las creaciones culturales. Cuando es propalada en los medios de comunicación de masas, la cultura se autolegitima y vale como mercancía independientemente (o incluso a falta de) su valor estrictamente estético. Para Theodor Adorno (1964: 10), en la industria cultural "las masas no son el factor primordial, sino un elemento secundario, un elemento de cálculo; un accesorio de la maquinaria”. Las personas, así masificadas, son destinatarias y no actoras en ese proceso. Son consumidores y no ciudadanos, como diríamos en una clave analítica más reciente.

Las reflexiones en torno al término industria cultural les permitieron a autores como Adorno, Max Horkheimer y más adelante Herbert Marcuse y Hans Magnus Enzensberger subrayar la masificación en la producción de contenidos, su carácter mercantil, la perplejidad del público homogeneizado y el verticalismo en la propagación de posiciones ideológicas. Esas contribuciones fueron muy importantes para develar los sesgos políticos e ideológicos de la comunicación de masas, aunque a menudo hayan sido un tanto mecánicas al prescindir de un análisis más fino de la complejidad de los públicos (de los cuales hay que hablar en plural) de la comunicación de masas. 
CONTINUIDAD Y CONTRAPOSICIÓN

EN DOS CONCEPTOS QUE COEXISTEN

A la Escuela de Frankfurt, aunque sería necesario un examen más puntual para aquilatar sus contribuciones con frecuencia brillantes y pioneras, se le puede señalar una insuficiencia básica. El interés por cuestionar la reproducción industrial de contenidos a menudo soslaya la creatividad individual que es el principio de cualquier proceso de producción cultural. Ya sea que se multiplique gracias a técnicas de reproducción y/o propagación de contenidos, o que se muestre en ejemplares únicos o casi únicos, la creación cultural tiene una dosis de originalidad e ingenio que la singularizan y le confieren valor tanto en sentido mercantil como estético.

El juicio crítico que se encuentra en la concepción de las industrias culturales subraya la masificación y de allí las posibilidades de manipulación y alienación del público sometido a contenidos que se repiten una y otra vez, o de uno a otro sitio, sin modulaciones ni cambios. La obra cultural reproducida masivamente, o para públicos de masas, en la era de las industrias culturales, por lo general es un contenido que se repite hasta parodiarse a sí mismo: se trata de creaciones que no cambian.

La creación cultural que se desarrolla a partir de los últimos años del siglo xx y que descansa en la reproducción digital puede ser más maleable y modificable, pero además, la multiplicación de copias se realiza con una calidad que no tienen las versiones analógicas. Aunque el entorno digital favorece la reproducción a escalas nunca antes vistas (como sucede con los contenidos populares en Internet que son replicados mucho más allá de lo que pueden advertir sus creadores), allí también hay contexto para reconocer la influencia y creatividad de los autores. 
El concepto de industrias creativas nace en parte como continuación, pero también en contraposición a la idea de industrias culturales. En los circuitos empresariales y de gobierno que promueven el desarrollo de iniciativas culturales y que convergen en organismos internacionales dedicados a esos menesteres, la idea de industrias culturales resultaba incómoda tanto por su origen marxista como por los cuestionamientos que implica a la manipulación ideológica. Por otra parte, algunos estudiosos interesados en comprender y clasificar las actividades culturales en el entorno global y digital de nuestros días encontraron que aquel término resultaba insuficiente.

El investigador español Enrique Bustamante ha escrito que las industrias culturales implican "toda una serie de creaciones simbólicas que, multiplicadas en numerosas copias en soportes materiales o inmateriales, van al encuentro de sus receptores" (Bustamante, 2003: 13). Es decir, las multicitadas industrias culturales sólo tienen sentido y relevancia si se reconoce a sus públicos. Para decirlo de manera obvia, sin masas no hay comunicación de masas; sin públicos no hay contenidos que sean recibidos, comprendidos y/o decodificados. A las industrias culturales, hay que entenderlas en el contexto del proceso comunicativo que desemboca en los receptores.

La idea de industrias creativas es tan reciente y pragmática, pero además se refiere a sectores tan cambiantes, que no tiene una definición suficientemente completa. Desde el campo de la consultoría ligada a las empresas, se les ha descrito como "actividades que tienen su origen en la creatividad del individuo, la habilidad y el talento, y que tienen potenciales para la creación de empleo y trabajo a través de la generación y explotación de propiedad intelectual" (Braun y Lavanga, 2007, apud Bustamante, 2011: 123). 
Esa concepción subraya los dos ejes en los que descansan las industrias creativas. Por un lado, el ingenio individual. Por otro y al mismo tiempo, su aprovechamiento para hacer negocio. Creación de fuentes de empleo, utilización y reivindicación de la propiedad intelectual y otras consecuencias virtuosas de las industrias culturales dependen del usufructo económico. Nada hay de cuestionable en la inversión financiera tanto privada como pública para respaldar iniciativas de carácter cultural. Pero cuando la cultura depende sólo o de manera importante de los réditos económicos o políticos cuando las inversiones que la propician son de carácter público, entonces la creatividad que se postula como valor esencial puede quedar en entredicho.

INVERSIONES, NEGOCIO Y RÉDITOS:

RELEVANCIA Y RIESGOS CULTURALES

En la sociedad contemporánea, cultura y emprendimiento financiero están estrechamente ligadas. De hecho, y para aportar un punto de vista adicional, se puede reconocer que gran parte de la creación cultural, en cualquier terreno en el que se piense (cine y televisión, teatro y artes plásticas, juegos digitales, etcétera) son impulsados con el propósito de hacer negocio. Pensemos en las aplicaciones (apps) que empleamos en nuestros teléfonos celulares, en las series producidas por empresas de distribución audiovisual en línea como Netflix o en las exposiciones de grandes pintores que reúnen el Moma neoyorquino, el Museo Reina Sofía en Madrid o la Tate Modern Gallery en Londres. En todos esos casos, se requieren fuertes inversiones financieras para las cuales se busca alguna forma de recuperación, ya sea monetaria y/o social o incluso mediática. 
Esas empresas culturales, que funcionan como industrias creativas, obedecen a capacidades y necesidades que ha desarrollado la sociedad contemporánea. Sobre todo en los países más desarrollados, pero también en aquellos con economías en desarrollo, el consumo cultural se ha convertido en negocio social y empresarial pero además es una exigencia creciente de los ciudadanos. La gente cuenta con más tiempo para ejercer su ocio de maneras variadas y versátiles y además tiene capacidad de consumo, aunque a veces con limitaciones, para pagar por los productos que satisfacen sus deseos de entretenimiento, contemplación, aprendizaje o experiencia cultural.

El negocio de la cultura se ha convertido en uno de los más dinámicos y fructíferos en las economías contemporáneas. Quizá el autor que ha reflexionado sobre estas tendencias con más riqueza informativa y analítica es Gilles Lipovetsky, que ha escrito sus libros recientes al alimón con Jean Serroy. Esos especialistas (2015: 38) explican la "generalización de la dimensión empresarial de las industrias culturales y creativas. Los mundos del arte son cada vez menos un 'mundo aparte' o una 'economía al revés': están regidos por las leyes generales de la empresa y de la economía de mercado, con sus imperativos de competencia y rentabilidad".

Las industrias creativas se despliegan en el escenario creado por la sociedad de la información. La digitalización de contenidos, la posibilidad de propagarlos a escala global, la expansión de Internet con su carácter reticular y la catarata de información a la que estamos cotidiana y crecientemente expuestos forman parte de ese nuevo entorno.

Sociedad de la Información le hemos llamado siguiendo denominaciones pioneras de pensadores como Daniel Bell y Manuel Castells (Trejo Delarbre, 2006) a ese entorno que circunscribe de manera desigual las relaciones sociales y 
culturales y que está sujeto a coberturas, prácticas y restricciones distintas de un país a otro pero que indudablemente se ha convertido en motor a la vez que en resultado de la globalización contemporánea.

El hecho de que tengamos ese contexto al que llamamos sociedad de la información no significa que todos compartamos las mismas concepciones ni que esa información se traduzca por sí sola en conocimiento. Hablar de sociedad de la información no implica legitimarla como sociedad del conocimiento. Se trata de dos momentos diferentes. La primera resulta del diagnóstico de los datos y contenidos a los que podemos tener acceso en las sociedades contemporáneas. La otra, la sociedad del conocimiento, es una aspiración sustentada en la sociedad de la información.

Al ubicar las industrias creativas en el contexto de la sociedad de la información, los promotores de ese término subrayan la relevancia de las tecnologías digitales en la propagación de la cultura, pero además buscan revestir esas actividades con el prestigio público que tiene el entorno digital. El investigador Nicholas Garhnam ha explicado de qué manera en el Reino Unido, y de manera más amplia en Europa, la etiquetación de las actividades culturales y mediáticas como industrias creativas está relacionada con la gestión de recursos públicos. En vez de estar orientada por la búsqueda y administración de respaldo para las artes, la política cultural sería definida por prioridades de la sociedad de la información (Garhnam 2011, p. 46). Para ese investigador británico, la denominación industrias creativas "sirve como eslogan, como referencia rápida, y por ello moviliza irreflexivamente un conjunto de posiciones políticas y teóricas que lo apoyan. Esta falta de reflexión es esencial para alcanzar su poder ideológico" (Garhnam, 2011: 22). 
CONTENIDOS CREATIVOS, VALOR ECONÓMICO Y EMPRESAS

Las prevenciones de Garhnam destacan el sesgo ideológico que tiene el término que nos ocupa, así como algunas de sus implicaciones. Desde luego, las industrias creativas no podrían explicarse al margen de la sociedad de la información. Unas y otras se expanden gracias a las plataformas digitales y requieren de reglas para resolver dilemas y conflictos que se suscitan debido a la circulación de contenidos. De hecho, y en alguna medida, en la discusión internacional desde comienzos del siglo xxi se habla de industrias creativas como reacción a la intensa y en buena medida incontrolable propagación de contenidos en línea. Pero la dependencia de la cultura respecto de consideraciones ajenas a la creatividad y la libertad implica riesgos claros.

En 2010 la Conferencia de las Naciones Unidas para Comercio y Desarrollo, unCTAD, describió así a las industrias creativas (los subrayados en esta cita son nuestros):

Son los ciclos de creación, producción y distribución de los bienes y servicios que tienen como base fundamental la creatividad y el capital intelectual; [...] constituyen un conjunto de actividades basadas en el conocimiento, pero no limitándose en las artes, para generar ingresos en relación al comercio y derechos de propiedad intelectual [...] Comprenden productos tangibles e intangibles o servicios artísticos con contenido creativo, valor económico y objetivos de mercado (PNUD y UNCTAD, 2010: 34).

Los términos subrayados en el párrafo anterior destacan la diversidad de condiciones $u$ opciones que toman en cuenta los promotores de la idea de industrias creativas. Se trata de actividades de elaboración y circulación que pasan por varias fases, de allí que se hable de ciclos. La producción de bienes 
culturales tiene sentido en tanto que se le distribuye (como sucede con las industrias culturales), y se menciona expresamente la importancia del capital intelectual. En ese concepto hay una doble implicación. Por una parte, se reconoce con toda claridad la importancia de la creación de ideas, por otra, se le considera un insumo necesario en las actividades de esa índole. A la creación intelectual no se le menciona como simple actividad o trabajo, sino como capital.

Ese término cobra sentido con mayor claridad en el segundo fragmento. Las industrias creativas han de generar ingresos. No está mal. De hecho, es plausible esa mención de la centralidad que tiene el trabajo intelectual y/o creativo. Pero cuando ese reconocimiento queda supeditado al rédito monetario, uno puede preguntarse si la creatividad sólo importa cuando hay rendimientos financieros. Desde luego, sin dinero no hay industria, pero ¿la producción de software que no resulta exitosa, las novelas que se venden poco o las películas que no alcanzan las cuotas de taquilla necesarias para recuperar la inversión que las ha hecho posibles quedan fuera de la definición de ese organismo internacional porque no han generado ingresos?

La dependencia que se propone que tenga la cultura respecto de la economía queda subrayada en el tercer fragmento de esa definición de la UNCTAD. Las industrias creativas, se dice, han de tener valor económico y objetivos de mercado. De hecho, cualquier creación tiene el primero de esos atributos. Todo vale, aunque sea poco o nada. Pero a ese valor se le ubica dentro del mercado que por supuesto impone un contexto de competitividad, ceñido por la demanda y la oferta, a cualquier bien, cultural o no, que sea puesto a circular. El problema radica en la idea de que las actividades culturales reconocidas como industria deban contar con "objetivos de mercado". 
INVENTARIO DE LA INVENTIVA.

UNA PROPUESTA DE CLASIFICACIÓN

De acuerdo con esa concepción, el mencionado organismo internacional y, de manera más amplia, la discusión sobre el tema, consideran industrias culturales a una muy variada gama de actividades. A partir de diversas clasificaciones (PNUD y UNCTAD, 2010: 31 y ss.), elaboramos este inventario de industrias creativas.

1. Artes tradicionales: música, literatura, pintura, teatro y artes escénicas, artes visuales.

2. Industrias culturales: cine, libros e industria editorial, fonogramas.

3. Medios de comunicación: televisión, radio, prensa.

4. Instituciones de cultura: museos, bibliotecas, archivos, colecciones, promoción cultural.

5. Actividades creativas: fotografía, artesanías, deporte.

6. Emprendimiento creativo: publicidad, moda, diseño, arquitectura.

7. Procesamiento digital: software, videojuegos, productos electrónicos.

No incluimos a la Internet en este inventario. Preferimos reconocerla como parte del contexto de toda la actividad informática y creativa en nuestros días. La red de redes es un medio de medios: en ella se reproducen contenidos de todos los medios de comunicación y surgen expresiones peculiares que no han pasado por los sistemas comerciales y/o institucionales para la propagación de mensajes. A pesar de no estar mencionada en ninguna de las siete categorías, y precisamente por eso, la Internet se encuentra imbricada con todas ellas.

La anterior clasificación por supuesto es discutible. Se trata de categorías distintas que pueden traslaparse unas con otras. De las artes tradicionales, con frecuencia resultan 
productos que nutren a las industrias culturales. A los medios de comunicación no se les puede entender sin las actividades enlistadas en los dos primeros rubros. Todas las que mencionamos son actividades creativas y no únicamente las incluidas en el punto 5. Hoy en día, los procesos digitales están vinculados de una u otra manera con todas las actividades mencionadas.

De cualquier manera, esa clasificación permite resaltar e identificar la muy amplia variedad de actividades consideradas entre las industrias creativas. Todas ellas están o pueden estar relacionadas con las actividades económicamente productivas. Y todas dependen del talento, la imaginación y, desde luego, la creatividad de quienes las practican.

Definiciones y clasificaciones como las anteriores permiten organizar la discusión acerca de las industrias creativas, a la vez que suscitan cuestionamientos elementales. Tales actividades son espacios o recursos de creación, pero además de propagación de contenidos. En la sociedad digitalizada de nuestros días, cada vez hay más contenidos que se producen no para públicos amplios o generalistas, sino para segmentos de audiencias o destinatarios específicos.

LIBERTAD, APERTURA Y

ACCESO CON RESPALDOS DIGITALES

La inquietud más importante que surge ante definiciones como la que comentamos es la dependencia que la creatividad puede tener respecto de los procesos industriales y de las tendencias e incluso exigencias de los mercados. Como posición de principio, es factible sostener que en toda creación de contenidos tendrían que existir amplias garantías para el desarrollo y el ejercicio de la diversidad, libertad, 
originalidad y calidad. Sin embargo, las presiones del mercado, que siempre han existido, pueden multiplicarse debido a la amplia propagación de contenidos que permiten ahora las redes digitales.

La centralidad de los autores en la concepción de industrias creativas implica, como señalamos antes, un reconocimiento justo. Si el talento es el origen de la creatividad que singulariza tales actividades, nada más importante que defender el crédito y los derechos de los autores. Pero la defensa de los derechos autorales puede estar más relacionada con intereses de corporaciones privadas que con el trabajo de los creadores individuales. Cuando el autor de una melodía, un guion cinematográfico o una fotografía, por ejemplo, ha sido patrocinado por una empresa y/o le ha vendido sus derechos sobre esa creación, entonces el interés para defender derechos autorales no es del creador original. La disputa por el plazo que deben estar vigentes los derechos de autor antes de que una obra pase a ser del dominio público ha mostrado el intenso y lucrativo interés de las empresas que se dedican a tareas consideradas como creativas.

El debate sobre estas industrias también involucra a las tareas del Estado en la promoción de la cultura. Si se les ubica bajo una definición de industrias creativas como la que hemos comentado, numerosas actividades de creación y difusión cultural pueden quedar supeditadas a consideraciones comerciales. El profesor canadiense Gaëtan Tremblay (2011: 74) ha expresado su preocupación ante

La disolución de la especificidad de las industrias culturales y el debilitamiento del argumento a favor de la intervención de los poderes públicos. Las nociones de servicio público y de los bienes de mérito, por ejemplo, bastante maltratadas por el neoli- 
beralismo de las últimas décadas, corren el riesgo de perder toda credibilidad si se intenta extender su aplicación a dominios como la moda y el videojuego.

\section{ArChivos y COLECCIONES \\ EN EL INEVITABLE CONTEXTO DIGITAL}

La digitalización implica cambios en la creación, reproducción, circulación, conservación y almacenamiento de los contenidos mediáticos (y, en general, de todo tipo de documentos). Los contenidos que son elaborados en formato digital, o convertidos a él, pueden ser enviados a distancia o colocados en línea para ser accesibles a grandes cantidades de usuarios. La disponibilidad y clasificación de libros, documentos y archivos de toda índole, e incluso su preservación, se facilitan gracias a los recursos digitales.

Archivos, bibliotecas y colecciones reúnen la memoria de nuestras sociedades. El aislamiento y la inaccesibilidad que con frecuencia tienen los acervos originales pueden remediarse, al menos en parte, gracias a los recursos digitales. Incluso las dificultades de espacio, clasificación y propagación de documentos reunidos en tales instituciones son aminoradas cuando esos contenidos son procesados, copiados u organizados de manera digital.

La informática y la compresión de contenidos, para que pueda almacenarse más documentos en menos espacio, permiten incluso que la necesidad de seleccionar y discriminar entre unos documentos y otros, que constituye un dilema frecuente para bibliotecarios o archivistas, pueda resolverse. El propósito ideal es que los responsables de compendiar colecciones no tengan que discriminar documentos en beneficio del espacio. Es más adecuado guardar y conservarlo 
todo. Las cartas personales, los archivos oficiales o las publicaciones que hoy pueden parecer insustanciales o triviales, mañana o pasado mañana pueden alcanzar importancia histórica.

La compilación y el mantenimiento de colecciones requiere de la mayor libertad y, si se nos permite el término, de la más escrupulosa neutralidad académica. No pretendemos que el trabajo académico carezca de sesgos o preferencias, pero sí que es pertinente reconocerlas y, cuando se trata de establecer criterios y tomar decisiones de selección, hacer todo lo posible para evitar que propicien exclusiones.

De los acervos documentales, que entre otras funciones sirven de respaldo para el desempeño de otras industrias creativas, es indispensable que sean compilados, clasificados, resguardados y puestos a disposición de sus usuarios con plena libertad y transparencia. Por eso resulta pertinente que no se les considere como una industria creativa más. Sobre todo, es necesario que la existencia y el desarrollo de tales acervos no estén supeditados a prioridades mercantiles ni a criterios de selección estética, política o de cualquier índole. 


\section{Bibliografía}

Adorno, T. (1967). "La industria cultural". En Theodor W. Adorno y Edgar Morin. La industria cultural. Buenos Aires: Galerna.

Braun, E. y M. Lavanga (2007). An International Comparative Quick Scan of National Policies for Creative Industries. Rotterdam: EURICUR / Erasmus University. Citado en Bustamante (2011).

Bustamante, E. (2011). Industrias creativas. Amenazas sobre la cultura digital. Barcelona: Gedisa.

(2003). "Las industrias culturales, entre dos siglos". En Enrique Bustamante (coord.). Hacia un nuevo sistema mundial de comunicación. Barcelona: Gedisa.

Garnham, N. (2011). "De las industrias culturales a las creativas. Análisis de las implicaciones en el Reino Unido". Citado en Bustamante (2011).

Lipovetsky, G. y J. Serroy (2015). La estetización del mundo. Vivir en la época del capitalismo artístico. Barcelona: Anagrama.

PNUD y UNCTAD. (2010) Economía creativa. Informe 2010. (Copia en PDF, sin pie de imprenta).

Tremblay, G (2011). "Desde la teoría de las industrias culturales. Evaluación crítica de la economía de la creatividad". Citado en Bustamante (2011).

Trejo Delarbre, R. (2006). Viviendo en El Aleph. La Sociedad de la Información y sus laberintos. Barcelona: Gedisa. 


\title{
Representación temática de los noticieros en la web
}

\author{
Silvano Soto Hernández \\ IDMS Consulting, SC
}

CONSIDERACIONES INICIALES

O i existe una industria que en el momento actual requiere del soporte científico y metodológico de la bibliotecología y los estudios de la información, ésa es la televisión. Esta participación académica tiene como objetivo exponer algunas de las posibles contribuciones de la disciplina referida a la representación temática de los noticieros en México.

A través del tratamiento y análisis documental se accede al contenido para generar ciertos productos como el resumen y la atribución de ciertos términos, o bien, palabras clave que describan el tema y los subtemas albergados en un soporte impreso, digital o de otra índole, tal como sucede con cierto tipo de obras artísticas. En este contexto, la representación temática es un proceso de producción léxico-conceptual que facilita la organización del conocimiento y la información. A su vez, permite la concreción de otros aspectos igualmente relevantes como la clasificación 
y la catalogación. En consecuencia, tiene un efecto en las probabilidades de visibilidad y recuperabilidad ante las demandas de información de los usuarios en diversidad de centros documentales (Naumis, 2008).

En la web, los motores de búsqueda son la puerta de acceso para los usuarios hacia los contenidos. Ante una consulta, devuelven páginas de resultados donde se enlistan recursos de información jerarquizados bajo ciertos criterios como la frecuencia con la que es visitado, la relevancia del tema y, desde luego, la efectividad de la representación temática.

La presentación de estos resultados no siempre es orgánica, es decir, no en todos los casos obedece a la calidad del recurso de información y su representación temática. Considerando que los motores de búsqueda también forman parte de una industria, la venta de primeras posiciones (posicionamiento) y de anuncios pagados también forma parte de los hallazgos que recibe el usuario una vez que realiza una petición.

Centro esta exposición en el posicionamiento orgánico, con la finalidad de que los motores de búsqueda faciliten la visibilidad y recuperación de la información: El productor de los contenidos web debería seguir una serie de recomendaciones, entre ellas las que están vinculadas con la representación temática. Éstas son aplicadas de manera prácticamente indistinta al texto, imágenes fijas, videos y otros recursos, por ejemplo, las presentaciones ofimáticas (MS Power Point, Keynote, Prezi, etcétera).

REPRESENTACIÓN TEMÁTICA

DE LOS NOTICIEROS EN LA WEB

El término noticiero, como se le denomina de manera coloquial en la industria audiovisual mexicana (más por usos y 
costumbres que por preceptiva) es un producto periodístico complejo manufacturado por una organización televisora, o bien, una agencia de información. De acuerdo con el diccionario de la Real Academia Española, el noticiero se define como: "adj. Que da noticias. Periódico noticiero.; m. y f. Persona que da noticias por oficio.; m. Cuba, El Salv., Guat., Ur. y Ven. noticiario (II programa de radio o de televisión)”. En tanto, el noticiario como: " $\mathrm{m}$. Programa de radio, cine o televisión en que se dan, generalmente ilustradas, noticias de actualidad. $\mathrm{m}$. Sección de un periódico en la que se dan noticias diversas, generalmente breves".

Para contrastar la caracterización de los términos, se realizó la búsqueda en algunos diccionarios con mayor grado de especialización en comunicación (escasos en español, por cierto), como el desarrollado en México por Rodríguez Vázquez, donde se define noticiario como "Programa de tipo informativo y periodístico en cine, radio o televisión, que presenta o da las noticias ilustrándolas con filmes, fotografías, declaraciones grabadas o videos" (2016: 298). Esta entrada no consideró las nuevas plataformas para la difusión digital con base en Internet y el entorno web. Luego, en la misma obra, siguiendo la orientación del Diccionario de la Real Academia, noticiero es definido como "Persona o presentador de una emisión que da las noticias".

En el Diccionario Enciclopédico de Ciencias de la Documentación, coordinado por López Yepes (2004: 254), el responsable de la sección de medios de comunicación, José Luis del Río Sadornil, profesor titular de la Facultad de Ciencias de la Información en la Universidad Complutense de Madrid, señala respecto al término noticiario:

Programa de noticias difundido por la radio, el cine o la televisión. También cualquier sección de noticias breves, de la misma o de distinta 
naturaleza. En un principio, se llamaron así a las informaciones de actualidad que se emitían como antesala de las películas de las proyecciones cinematográficas [...] El noticiario plantea, como género, una separación casi estricta entre los contenidos de la banda de imagen y la banda de sonido. La imagen ilustra, recrea, divaga en aquello que el texto cierra. Esta distinción se hace en presencia de una "VOZ en off», que asume la función de narrador, dando cohesión y homogeneidad narrativa a la diversidad y dispersión de las noticias e imágenes.

Río Sadornil no incluye el término noticiero dentro de las entradas del Diccionario Enciclopédico de Ciencias de la Documentación. No obstante, tal como sucede con el vocabulario de corte profesional y técnico que varía entre los diferentes contextos sociolingüístico y semántico, ha incorporado un término de uso en la mayoría de las televisoras de España: el telediario, que define como "Conjunto de noticias e informaciones de naturaleza diversa, debidamente jerarquizado, que cada día emite la televisión, generalmente en horarios fijos. La estructura de su contenido es similar a la de un diario impreso" (López Yepes, 2004: 484).

En México, se utilizan de forma indistinta las expresiones noticiero y noticiario, con privilegio a la primera forma, que se incorpora al vocabulario profesional, técnico y de la audiencia. El uso se ha fijado en el contexto sociolingüístico y semántico con base en la frecuencia de repetición de títulos de este tipo de contenido audiovisual en las campañas de promoción. Por ejemplo, en Televisa están $E l$ Noticiero con Guillermo Ortega o El Noticiero con Joaquín López-Dóriga.

Otras televisoras utilizan títulos diferentes como Hechos en TV Azteca u Once Noticias en el Canal 11 del Instituto Politécnico Nacional. Sin embargo, la audiencia los reconoce 
como "el noticiero de Javier Alatorre" o "el noticiero de Javier Solórzano", a quienes, por cierto, igual que a los titulares de Televisa, se les reconoce como "conductores" y no como "noticieros" o lectores de noticias.

Desde la conceptualización jurídica, según el país y su legislación, como en el caso mexicano, es posible expresar que el noticiero es una obra intelectual colectiva resultado de la actividad periodística desarrollada por una estación televisora (la denominación puede variar de un país a otro, y, por tanto, de un contexto jurídico a otro. Para el caso mexicano, $c f r$. la Ley Federal del Derecho de Autor).

En este sentido, de forma colectiva y consensuada, el noticiero es la suma de un conjunto de fragmentos de discurso producidos en formato de texto, sonido e imágenes fijas o en movimiento, con o sin sonido, cuya difusión, distribución, publicación y comercialización está regulada por las leyes vigentes en materia de derecho de autor y televisión de cada país.

Llama la atención que diccionarios técnicos de cine y televisión, como el de Páramo, no proporcionen una entrada que defina o delimite conceptualmente al noticiario. En todo caso, la entrada más cercana sería la de programa: "Material audiovisual que, junto con las expresiones secuenciales, va a ser utilizado para la presentación de una producción audiovisual que, normalmente, se pasará más tarde en TV" (Páramo, 2002: 560). Esta definición resulta confusa y ambigua.

En Maza, "un noticiario es el equivalente audiovisual del periódico. Podría definirse como un producto del periodismo audiovisual, estructurado con base en una serie de descripciones y narraciones de eventos que se consideran relevantes porque afectan directa o indirectamente a un público o audiencia" (1999: 281).

Para contribuir a la discusión, Aguado agrega que "el noticiario es aquel programa que informa sobre los hechos y 
sucesos de actualidad para mantener al tanto de la problemática cotidiana tanto a nivel regional como nacional e internacional, en los campos más diversos de interés social: política, economía, salud pública, seguridad social, educación, etcétera" (2005: 49). Habría que agregar que también expone eventos en retrospectiva. Tomando en consideración la mirada del análisis funcionalista de Lasswell y Wright, el noticiero es un producto periodístico audiovisual que se transmite por televisión y que tiene como propósito cumplir con las funciones asignadas a los medios de comunicación de masas: supervisión del entorno, correlación, transmisión de la cultura y entretenimiento.

Con el ánimo de profundizar y aproximarse a una definición del noticiero de televisión, habría que caracterizar bajo la mirada estructuralista y semiológica a las funciones de este producto periodístico. En este sentido, el noticiario es una macroestructura resultado de la combinación y yuxtaposición de signos lingüísticos y audiovisuales (imágenes fijas y en movimiento, sonido ambiental, efectos de sonido, voz, música, entre otros).

Siguiendo el planteamiento que Van Dijk propone para el análisis de discursos y textos periodísticos, Gil Leiva (2008: 2123) añade que el noticiero es una macroestructura. Al realizar su investigación, identificó que bien podría tratarse del resultado de tres articulaciones de signos. Hay una articulación al nivel de microestructuras en la que se conjuntan los textos leídos por el presentador con unidades sintagmáticas igualmente complejas como noticias, reportajes, entrevistas, crónicas, etc. A la vez, estas microestructuras se articulan a partir de proposiciones menos complejas equivalentes a las oraciones en un discurso completamente textual, en los que texto, sonido, e imágenes en movimiento, principalmente, se yuxtaponen a través del proceso de montaje o edición electrónica. Cada noticiero guarda un determinado nivel de coherencia y congruencia 
entre las proposiciones, las microestructuras y las macroestructuras. Esto permite que el mensaje del noticiero pueda comunicarse con significado, sentido y dirección hacia el receptor (figura 1).

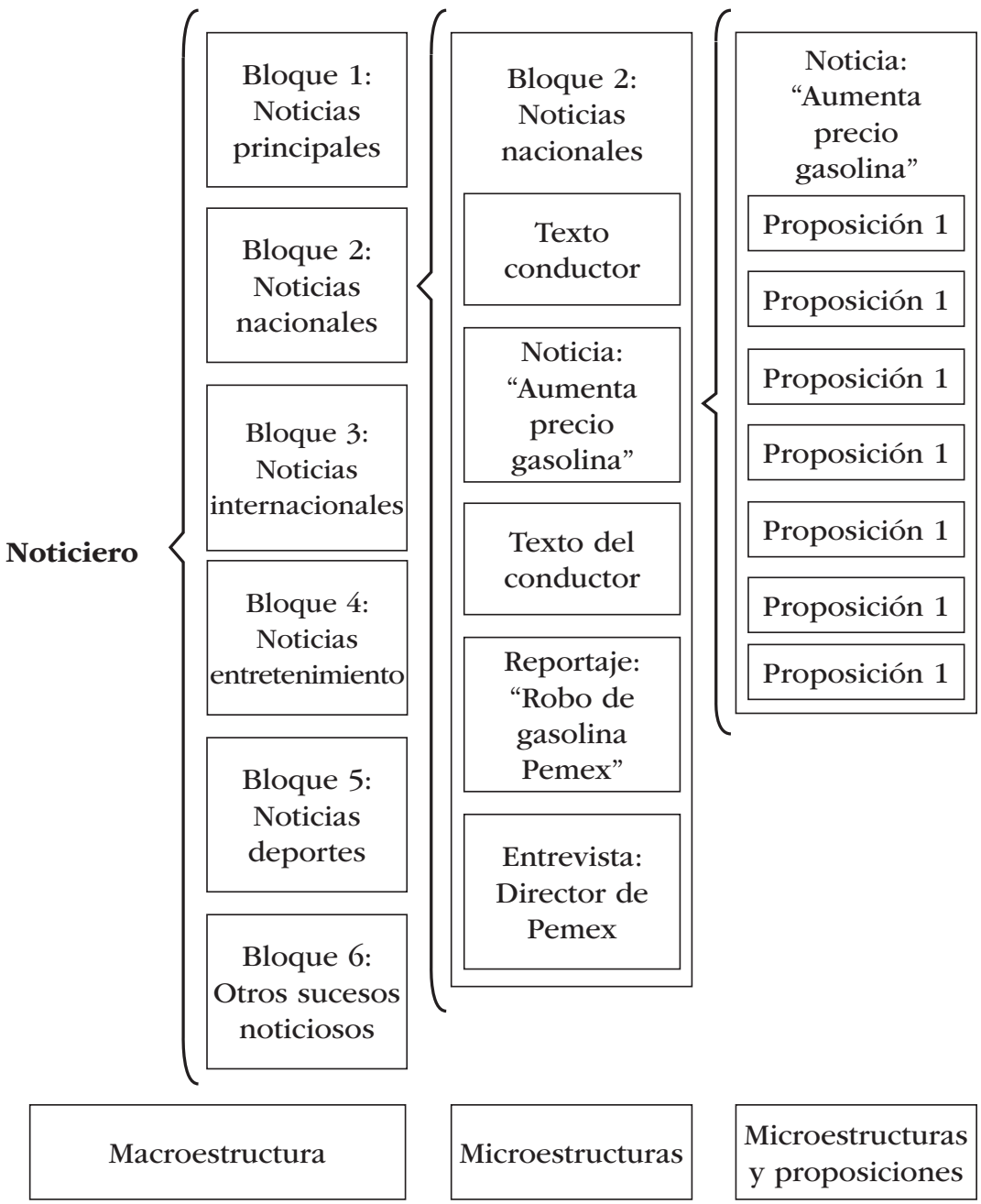

Figura 1. El noticiero como macroestructura. Elaboración propia. 
La definición aquí propuesta para noticiero representa un concepto complejo de la producción periodística audiovisual que incluye elementos de corte jurídico y tecnológico, funciones, estructura discursiva y un componente más que es el factor administrativo y operativo en el que se origina.

El noticiero se podrá comprender en el contexto de esta investigación como una obra intelectual (mensaje), producida de forma colectiva (una organización) a través de un proceso administrativo y un conjunto de operaciones de producción audiovisual con la colaboración de talento humano especializado en la actividad periodística, que genera documentos, archivos y colecciones que llegan a tener valor histórico y para la investigación social (emisor). Es resultado de la cobertura periodística de hechos relevantes, significativos y de interés para una comunidad determinada (contexto). Está codificada por medio de los lenguajes textual y audiovisual mediante la articulación de proposiciones, microestructuras y macroestructuras de signos - lingüísticos y audiovisuales - como el texto, el sonido y las imágenes fijas y en movimiento (código). Ha sido producida y transmitida, de forma analógica o digital, a través de la televisión y sus señales, sean abiertas, de paga o restringidas; también puede haber sido emitida en un portal web o en aplicaciones para dispositivos móviles (canal). Es dirigida hacia una audiencia específica conformada por varios segmentos de composición y características variables (receptor). Asimismo, es capaz de cumplir con una, varias o todas las funciones inherentes a los medios de comunicación de masas (supervisión del entorno, correlación, transmisión de la cultura y entretenimiento). De igual forma, es susceptible de llevar a cabo una retroalimentación de parte de los receptores que se efectúa a través de otros medios como las cartas a la dirección editorial del noticiero, las llamadas telefónicas, las 
redes sociales en Internet $y$, aunque de forma mediatizada, por medio de los indicadores de audiencia.

Los primeros esfuerzos por publicar los noticieros de televisión en la web fueron emprendidos por TV Azteca hacia finales de la primera década del año 2000. Este hecho marcó un antes y un después al implementar el uso de plataformas tecnológicas que facilitaron el flujo de datos de video (video streaming), y al embeber un código HTML o un código similar para incluir el reproductor para el usuario (video player). En aquel tiempo, se publicaban los episodios completos de los noticieros estelares sin incluir un título unificado para describir el contenido con el menor número de palabras posible. No se incluían resúmenes temáticos o referencias onomásticas a los protagonistas de las noticias; cuando más, se refería el nombre del conductor, por ejemplo, Javier Alatorre.

En los años siguientes, otras televisoras se unieron a esta tendencia que, sin haber surgido en México, cobraba fuerza en el país. Entre las empresas que se sumaron a este movimiento se encuentran Esmas.com (Televisa), que replicaba contenidos de Noticieros Televisa como cápsulas informativas (notas), reportajes, crónicas, reseñas y algunas secciones especiales (por ejemplo, "Las mangas del chaleco").

En el caso de Esmas.com, no se publicaban los noticieros como episodio completo debido a las consideraciones de carácter jurídico y de pago de derechos a agencias de información nacionales e internacionales que, dicho sea de paso, encarecían la operación web sin que hubiera un punto de equilibrio ni un retorno de inversión apropiado. Fue hasta que se constituyó Televisa.com, entre 2010 y 2012, cuando se llegó a un acuerdo comercial con los principales dueños de los derechos de propiedades digitales para que se difundieran los noticieros completos. 


\begin{tabular}{|l|l|l|l|}
\hline \multicolumn{1}{|c|}{ Televisora } & TV abierta & TV de paga & TV web \\
\hline $\begin{array}{l}\text { Aprende Televisión } \\
\text { Educativa }\end{array}$ & No aplica & $\mathrm{X}$ & $\mathrm{X}$ \\
\hline CNN en Español & No aplica & $\mathrm{X}$ & $\mathrm{X}$ \\
\hline Canal Once & $\mathrm{X}$ & $\mathrm{X}$ & $\mathrm{X}$ \\
\hline Efekto TV & No aplica & $\mathrm{X}$ & $\mathrm{X}$ \\
\hline Excelsior TV (*) & No aplica & $\mathrm{X}$ & $\mathrm{X}$ \\
\hline Foro TV/Televisa (*) & $\mathrm{X}$ & $\mathrm{X}$ & $\mathrm{X}$ \\
\hline Fuerza Informativa & $\mathrm{X}$ & $\mathrm{X}$ & $\mathrm{X}$ \\
\hline Milenio Noticias (*) & No aplica & $\mathrm{X}$ & $\mathrm{X}$ \\
\hline MVS Noticias & No aplica & $\mathrm{X}$ & $\mathrm{X}$ \\
\hline Noticieros Televisa & $\mathrm{X}$ & $\mathrm{X}$ & $\mathrm{X}$ \\
\hline Proyecto 40 & $\mathrm{X}$ & $\mathrm{X}$ & $\mathrm{X}$ \\
\hline Telefórmula & No aplica & $\mathrm{X}$ & $\mathrm{X}$ \\
\hline $\begin{array}{l}\text { Televisión } \\
\begin{array}{l}\text { Metropolitana Canal } \\
\text { 22 }\end{array}\end{array}$ & $\mathrm{X}$ & $\mathrm{X}$ & $\mathrm{X}$ \\
\hline $\begin{array}{l}\text { TV unam } \\
\text { Nota: Se tomaron en consideración las televisoras que producen y transmiten } \\
\text { por lo menos un noticiero al día. Los casos señalados con (*) son televisoras con } \\
\text { temática periodística, transmitiendo las 24 horas. }\end{array}$ \\
\hline
\end{tabular}

Cuadro 1. Noticieros televisivos mexicanos en la web. Televisoras según plataforma de distribución.

Fuente: Soto-Hernández y Naumis-Peña (2014).

Soto-Hernández y Naumis-Peña (2014: 80-86) reportaron cuáles eran las empresas e instituciones productoras de noticieros (aunque no cumplieran la condición de ser televisoras) que generaban y transmitían este tipo de contenido audiovisual en televisión abierta, televisión de paga y la web (cuadro 1).

Una vez que las empresas televisoras decidieron difundir en la web productos terminados como el noticiero televi- 
sivo, surgió la necesidad de incorporar otro tipo de perfil profesional conocido como editor web. Éste es responsable de asegurar la ejecución de una serie de tareas que van desde la preparación de los materiales, hasta otras vinculadas con el análisis de contenido. En el cuadro 2, se presentan las principales diferencias de ejecución en el tratamiento y

\begin{tabular}{|l|l|l|}
\hline Operación & \multicolumn{1}{|c|}{ Enfoque editorial web } & Enfoque bibliotecológico \\
\hline $\begin{array}{l}\text { Análisis del } \\
\text { contenido } \\
\text { de los elementos de mayor } \\
\text { relevancia periodística que } \\
\text { despierten la atención del } \\
\text { usuario. }\end{array}$ & $\begin{array}{l}\text { Orientado hacia la } \\
\text { organización del } \\
\text { conocimiento. }\end{array}$ \\
\hline $\begin{array}{l}\text { Elaboración } \\
\text { de resumen }\end{array}$ & $\begin{array}{l}\text { resumen, es decir, un } \\
\text { resumen de un contenido } \\
\text { periodístico creado } \\
\text { originalmente para la } \\
\text { televisión (primera pantalla). }\end{array}$ & $\begin{array}{l}\text { Redactado considerando } \\
\text { la organización del } \\
\text { conocimiento y las } \\
\text { necesidades de } \\
\text { información de la } \\
\text { comunidad a la que } \\
\text { atiende. }\end{array}$ \\
\hline $\begin{array}{l}\text { Descripción } \\
\text { temática }\end{array}$ & $\begin{array}{l}\text { Ejecutada desde } \\
\text { la perspectiva del } \\
\text { posicionamiento en motores } \\
\text { de búsqueda. }\end{array}$ & $\begin{array}{l}\text { Ejecutada desde la } \\
\text { perspectiva de los } \\
\text { lenguajes documentales. }\end{array}$ \\
\hline $\begin{array}{l}\text { Etiquetado o } \\
\text { tagging }\end{array}$ & $\begin{array}{l}\text { Realizada con el soporte de } \\
\text { herramientas especializadas } \\
\text { controlados, taxonomías, } \\
\text { ontologías, Topic Maps, listas } \\
\text { de términos descriptores. }\end{array}$ & $\begin{array}{l}\text { Realizada con el } \\
\text { soporte de herramientas } \\
\text { especializadas, } \\
\text { vocabularios controlados } \\
\text { taxonomías, ontologías, } \\
\text { Topic Maps, listas de } \\
\text { términos descriptores. }\end{array}$ \\
\hline
\end{tabular}

Cuadro 2. Diferencias de ejecución en el tratamiento y análisis documental. Elaboración propia. 
análisis documental. Por un lado, se muestran las operaciones bajo el enfoque del editor web y, por otro, las que se efectúan con la perspectiva bibliotecológica.

A reserva de desarrollar una exposición con mayor profundidad, se identificó que ambos enfoques tienen la oportunidad de coexistir y enriquecerse de forma bidireccional, aportando valor a la visibilidad y posicionamiento web al utilizar ciertos elementos de uso estratégico que proceden del contexto de la optimización para motores de búsqueda (Search Engine Optimization) y de la bibliotecología y los estudios de la información. Estos elementos se describen de forma general a continuación $y$, en todo caso, la recomendación principal consiste en darles el giro de la descripción temática; de este modo, los motores de búsqueda contarán con mayor soporte para la elaboración automática de resúmenes, representación e indización.

\section{Densidad de palabras Clave}

La densidad de una palabra clave se establece considerando el número de repeticiones o veces que aparece en el cuerpo de un texto que se presenta al usuario en un contenido publicado en la web. Es un indicador que se estructura en función del número de repeticiones en el contexto del total de palabras que conforman el texto de la página en cuestión (no del total del sitio web).

A través de la densidad de palabras clave, los motores de búsqueda determinan cuál es el asunto principal que se aborda en la página web (aboutness). Se recomienda utilizar todas las palabras de un mismo campo semántico incluyendo sinónimos, antónimos, variantes (plurales, prefijos, sufijos) y formas verbales. De este modo, aumenta la densidad de la temática sin necesidad de incrementar la repetición de las palabras clave. 
Es importante equilibrar la densidad de las palabras clave, así como su distribución en todos los espacios donde se pueda aumentar la relevancia. De otro modo, el abuso puede ser interpretado como spam por los motores de búsqueda e, incluso, puede haber una penalización en la evaluación de relevancia total del sEo de una página web. Las penalizaciones han sido impuestas por los motores de búsqueda para sancionar a editores web interesados en promover, mediante algún tipo de operación engañosa, las herramientas de indización.

Para calcular un estado óptimo de la densidad de palabras clave, se puede utilizar la fórmula donde la densidad de la palabra clave es igual al número de sus caracteres de texto, dividido entre el número de caracteres de la página web, multiplicado por 100. Si el rango es menor al 15\%, la temática estará pobremente representada. Por el contrario, si el rango es mayor al $70 \%$ la densidad es excesiva y podría llegar a ser interpretada como spam.

Etiqueta Title (<Title $>)$

Se refiere al uso imprescindible de la palabra clave que mejor represente el contenido de la página web en la etiqueta. Se considera balanceado el empleo de sesenta a ochenta caracteres como máximo para que aparezca correctamente en el snippet o descripción que proyectan las Search Engine Results Page (SERP). Este es un factor fundamental para que el usuario, al ver la palabra clave en el snipett, haga clic y vaya al sitio web o página interior. Se recomienda incluir en la página Home y procurar que el contenido de cada página interior cuente con la palabra clave que asegure la mejor representación en la etiqueta. 
ETiquetas Meta

(KEYWORDS, DESCRIPTION Y AUTHOR)

Para la evaluación de la relevancia que ejecutan los motores de búsqueda, estas etiquetas suelen ser poco pertinentes, excepto en el caso de las etiquetas meta que incluyen keywords o palabras clave. Por ejemplo, <meta name="Keywords" content="Chespirito, muere, Roberto Gómez Bolaños, noticias, información, especiales, notas, videos, curiosidades, nacional, internacional, por el planeta" $>$.

De igual forma, aplica la utilidad para las etiquetas meta que incluyen descripciones o representaciones del contenido, por ejemplo, $<$ meta name="Description" content="Lobos solitarios son la nueva amenaza. No están integrados en células terroristas, pero están dispuestos a cometer atentados en cualquier momento">.

Por último, aunque en sí es una variante onomástica, se encuentra la etiqueta meta para describir al autor. Un autor puede ser un tema, por ejemplo, <meta name="author" content="Carmen Aristegui">.

\section{ETIQueTas H1 y H2}

Las etiquetas $\mathrm{H} 1, \mathrm{H} 2$ y $\mathrm{H} 3$ permiten estructurar el discurso de texto de una página web en secciones separadas por epígrafes. La etiqueta $\mathrm{H} 1$ se utiliza para indicar el título principal de una página web (por ejemplo, el título de una noticia, reportaje, entrevista o artículo). Hay que incluir en ella la palabra clave que mejor represente el contenido.

Las etiquetas $\mathrm{H} 2$ se emplean para subtitular secciones dentro del cuerpo de un texto (por ejemplo, los epígrafes que separan las subsecciones de una noticia). Las etiquetas $\mathrm{H} 3$ se recomiendan para configurar apartados más pequeños dentro de las secciones del cuerpo del texto. 
TAGGING

(INTERNO Y SOCIAL)

La construcción y el uso de repertorios, vocabularios, diccionarios, taxonomías, ontologías y listas de palabras e incluso términos descriptores es una de las estrategias que agregan mayor control a la representación semántica de los contenidos en la web. Para ello, los Content Management Systems (CMs) pueden contar con editores de etiquetas (tags) para su representación semántica.

Por ejemplo, Adobe CQ5, una de las herramientas de fuerte calado en el mercado corporativo, cuenta con un editor especial para crear repertorios de palabras clave. Éstas se registran dentro de un módulo especial en el cMs para que posteriormente puedan ser utilizadas por los editores web responsables de las altas, bajas y cambios de contenidos.

Es recomendable contar con políticas y procedimientos claros para mantener actualizadas y vigentes todas las entradas de palabras clave.

En lo que concierne al social tagging, se recomienda su uso implementando en la arquitectura de información del cMs un diseño de hojas de estilo (css) capaz de soportar que los usuarios etiqueten o asignen palabras de vocabulario natural y coloquial, con la finalidad de generar mayor proximidad entre el contenido web y el estilo de la producción lingüística de las personas.

Asimismo, sería conveniente evaluar la posibilidad de que el usuario comparta a través de medios sociales por medio de la incorporación de la función de etiquetar o taggear a personas que forman parte de su lista de contactos o amigos.

De este modo, el contenido puede tener mayores posibilidades de aumento de visibilidad. 
Metadescripciones

La mayoría de los Content Management Systems (cms) disponibles en el mercado de software contienen editores de etiquetas para formar repertorios o vocabularios de palabras clave y, en su caso, términos descriptores. Como parte de estas herramientas, los editores web suelen tener a su disposición la asignación de las palabras clave a los contenidos web. De igual manera, tienen acceso a colocar descripciones verbales que representen el contenido dentro de campos que forman parte de la gestión del sEo. Se recomienda que el editor incluya en estas metadescripciones aquellas palabras clave que mejor representan el contenido web.

\section{Palabras Claves en URL}

La inclusión de la palabra clave en la URL se considera ya un estándar. El Content Manager System o cMs (herramienta que permite gestionar o administrar la creación, las altas, bajas y los cambios de contenido dentro de un sitio web; fundamentalmente es una herramienta de publicación) debería generar por cada página interior una URL que contenga la palabra clave con la menor extensión de caracteres. Éste es un indicador de relevancia para los motores de búsqueda. Resulta altamente recomendable en el caso de que se publiquen contenidos multimedia (fotos, videos e interactivos) y hay que evitar el uso de abreviaturas.

\section{USO EN LOS NOTICIEROS}

Si bien existen cada vez más estudios sobre Search Engine Optimization y algunos de éstos son producto de su aplicación en el ámbito del periodismo en la web, no ocurre lo mismo con 
la implementación en los noticieros de televisión llevados a la escena de Internet.

En lo que concierne a la producción y distribución de noticias, el seo llegó a las redacciones de noticias hace apenas una década, cuando impulsó entre los profesionales de media el diseño y la implementación de nuevas prácticas (Richmond, 2008) que se requieren sistematizar y estudiar a fondo. Newman y Levy (2014) reportaron que los motores de búsqueda continúan siendo la principal puerta de acceso para que los usuarios se conecten con las noticias, artículos, reportajes y contenidos periodísticos en video.

El impacto del sEo ha sido tal que, en 2009, la British Broadcasting Company (BBC) desarrolló una posición laboral de especialista en SEo Periodismo. En 2011, Los Angeles Times instituyó la figura de ejecutivo C-Suite denominada SEO Chief, que es considerada un factor clave para conducir las estrategias de incremento de tráfico (Ellis, 2011).

Estos y otros ángulos del tema han sido reportados por Giomelakis y Veglis (2015, 2016), quienes presentaron trabajos sobre la optimización del posicionamiento en buscadores web en relación a contenidos periodísticos. En 2016, publicaron un estudio centrado, por un lado, en la aplicación del SEO en sitios web con contenido en formatos de texto, imágenes fijas y video; por otro, en descubrir la frecuencia de uso que hacen los profesionales de la industria mediática en Grecia para incrementar el tráfico web.

Giomelakis y Veglis expusieron en su investigación que la literatura científica o especializada acerca de la relación entre SEO y periodismo es insuficiente en el contexto geográfico en general, así como en Grecia, territorio donde residen y en el que se localizan los medios de comunicación que formaron parte de su estudio de campo. No obstante, realizaron una recuperación de datos y hechos relevantes: 
De acuerdo con Stabiner (2011) y Bakker (2012), el SEO se puede comprender como un proceso que sirve a los editores web para crear y ajustar los encabezados de las noticias o los textos de sus publicaciones a fin de mejorar su posicionamiento en Google y otros motores de búsqueda, para tener mayores oportunidades de ser consultados por los usuarios.

Retoman a Spyridou y Veglis (2012), que señalan que las organizaciones periodísticas, entre otras, redefinen y modifican sus procesos para la producción de noticias alrededor del sEo con el propósito de enfrentar y asumir los desafíos del posicionamiento web, el cambio tecnológico y la convergencia digital. Giomelakis y Veglis concluyeron que:

- Existe una clara correlación entre el tráfico web y varios de los factores SEO como los hipervínculos internos (backlinks), la tasa de rechazo o rebote y la práctica de intercambiar información a través de hipervínculos externos.

- sEo puede tener un efecto significativo en la profesión periodística y, específicamente, llegar a jugar un rol relevante en la gestión de los sitios web ricos en recursos multimedia y en el desempeño del tráfico web.

- Los expertos en SEo anticipan una transición del modo tradicional en el que se gestionan los factores que consolidan el posicionamiento web, y buscan analizarlos y comprenderlos de manera más profunda para obtener ventaja de los contenidos con otro tipo de cualificaciones como los que aportan los medios sociales.

- El seo permanecerá por mucho tiempo como una de las claves para asegurar la calidad de las estrategias web en el mundo de los buscadores.

- Indudablemente, el uso adecuado del seo no garantiza la producción de un tráfico web elevado. No obstante, con una estrategia efectiva puede llegar a hacerlo y auxiliar a los profesionales 
de los medios de comunicación a obtener ventajas y rendimientos mayores.

- Las empresas de comunicación web y los periodistas necesitan estar conscientes y al pendiente del desarrollo tecnológico y comprender cómo se transforma la cultura del consumo de noticias en línea, a fin de tener la capacidad para crear mejores sitios web e incrementar las oportunidades de ser consultados por los usuarios.

Gonzalo, Codina y Rovira (2015: 19-27) añaden que las tendencias más recientes en materia de optimización de posicionamiento web en buscadores (SEO) se enfocan cada vez más en dos aspectos relacionados con los usuarios: el perfil del usuario que realiza la búsqueda y la interpretación de la intención de la búsqueda.

Asimismo, Iglesias-García, Pedraza y García-Carretero (2016) expresan la necesidad de que las informaciones periodísticas sean respaldadas por una política empresarial que les permita incrementar su visibilidad y posicionamiento web para alcanzar mejores métricas de desempeño en lo que concierne al tráfico de usuarios.

Soto Hernández y Naumis Peña (2014: 80-86) elaboraron una matriz en la que se representa el uso de elementos para mejorar el posicionamiento en motores de búsqueda. En la lista que aparece a continuación, se destacan con negritas los que tienen carácter semántico, temático y que son resultado de la producción léxico-conceptual del editor web o del profesional de la información. En el cuadro 3 se muestra la matriz.
A = Título del noticiero/noticia .
$\mathrm{B}=$ Fecha del noticiero/noticia .
$\mathrm{C}=$ Horario de transmisión/fecha y hora de posteo.
$\mathrm{D}=$ Conductores . 
$\mathrm{E}=$ Síntesis del noticiero/nota .

$\mathrm{F}=$ Palabras clave o términos descriptores.

$\mathrm{G}=$ Nombres propios de personas o lugares.

$\mathrm{H}=$ Temas relacionados .

I = Extensión de contenido en redes sociales.

$\mathrm{J}=$ Ofrece el noticiero en versión completa en vivo o bajo demanda.

$\mathrm{K}=$ Ofrece guión, escaleta, transcripciones o traducciones/subtítulos del noticiero completo.

$\mathrm{L}=$ Ofrece los fragmentos del noticiero bajo demanda.

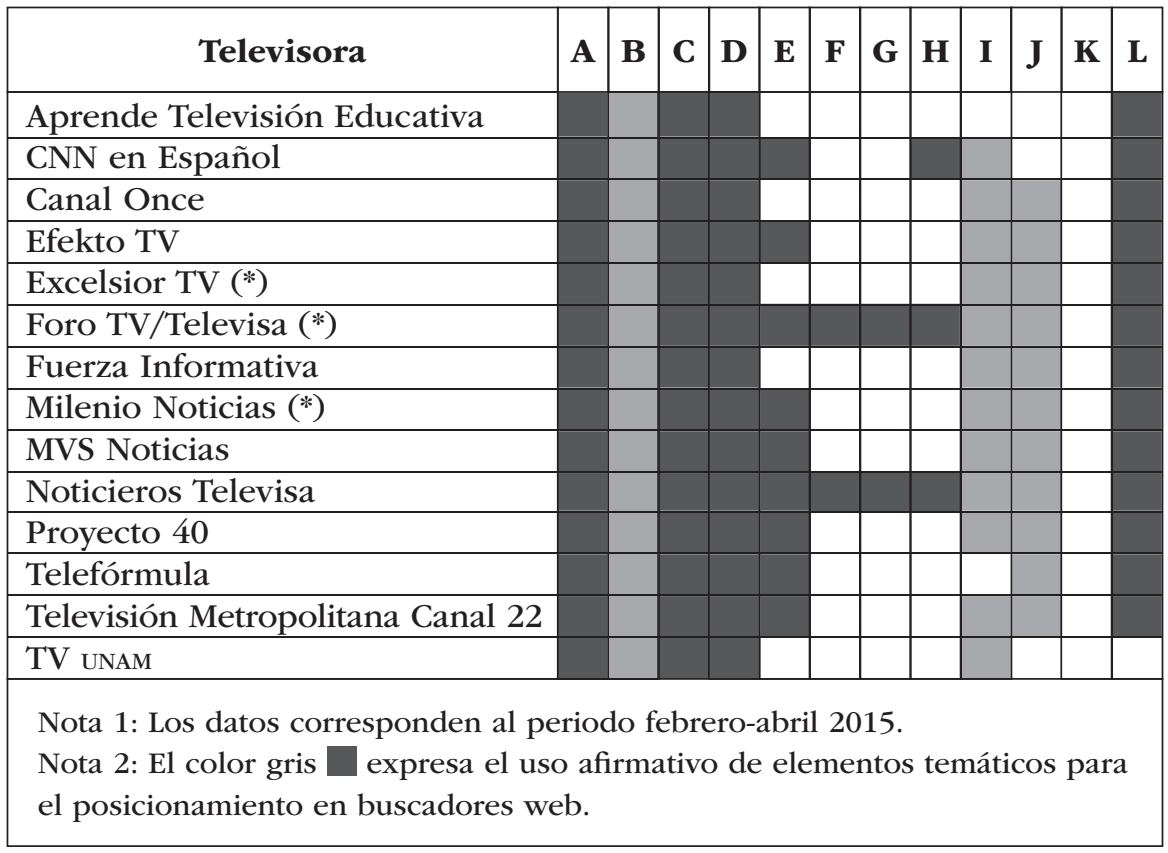

Cuadro 3. Noticieros televisivos mexicanos en la web. Uso de elementos temáticos para el posicionamiento en noticieros.

Elaboración propia. 


\section{Conclusión}

Los productores de contenido aspiran a contar con la mayor visibilidad posible en la web. En el caso de las televisoras y diarios que generan noticieros para la televisión, o bien, nativos para Internet, están a la expectativa de encontrar respuestas a las interrogantes que plantean los motores de búsqueda y los intersticios de las relaciones cognitivas que modelan los usuarios para estar en contacto con los contenidos que requieren o prefieren.

La riqueza semántica aportada por el tratamiento y el análisis documental brinda todas las oportunidades para fortalecer las estrategias de representación temática de los noticieros en la web. Está demostrado por los propios motores de búsqueda que el uso de una mayor cantidad y calidad de elementos semánticos y ciertos metadatos y microdatos técnicos facilitan los procesos de evaluación, indización y posicionamiento.

En la medida que un contenido web cuente con una estrategia de representación temática ejecutada con una perspectiva amplia, capaz de incluir las bondades del tratamiento y análisis documental, se lograrán también mayores niveles de satisfacción en los usuarios.

Las noticias en la web son un contenido valorado y de gran consumo a través de los portales de los periódicos y televisoras, lo mismo que en las redes sociales. De ahí que la necesidad de facilitar el vínculo con las personas consumidoras de estos productos audiovisuales supone un planteamiento de gran interés para la formación de recursos humanos profesionales e investigación especializada desde la bibliotecología y los estudios de la información a fin de brindar respuestas a la industria. 


\section{Bibliografía}

Aguado Cruz, E.F. (2005). Los géneros periodísticos de opinión en la televisión mexicana. Tesis de Maestría en Comunicación. México: unAm.

Bakker, P. (2012) "Aggregation, Content Farms and Huffinization". Journalism Practice, 6 (5-6): 627-637. doi:10.1080/17512786. 2012.667266.

Codina, L., M. Iglesias García, R. Pedraza y L. García Carretero (2016). Visibilidad y posicionamiento web de informaciones periodísticas: el framework SEO-RCP. Serie Editorial DigiDoc. Audiencias activas y periodismo. Barcelona: Departament de Comunicació, Universitat Pompeu Fabra. 2016.

Ellis, J. (2011). "Traffic Report: Why Pageviews and Engagement Are Up at Latimes.com". Nieman Journalism Lab, 16 de agosto.

García-Carretero, Lucia; Lluís Codina y Rafael Pedraza-Jiménez (2016). Indicadores para el estudio de la visibilidad y del impacto de los cibermedios en el ecosistema digital. Barcelona: Universitat Pompeu Fabra.

Gil Leiva, I. (2008). Manual de indización. Teoría y práctica. Gijón: Trea.

Giomelakis, D. y A. Veglis (2015). "Employing Search Engine Optimization Techniques in Online News". Studies in Media and Communication, 3. (1), 22-33.

_ (2016). "Investigating Search Engine Optimization Factors in Media Websites". Digital Journalism, 4 (3), 379-400.

Gonzalo, C, L. Codina, y C. Rovira (2015). "Recuperación de información centrada en el usuario SEO: categorización y determinación de las intenciones de búsqueda en la Web". Index. Comunicación, 5 (3), 19-27.

López Yepes, A. (2004). Diccionario Enciclopédico de Ciencias de la Documentación. Madrid: Síntesis. 
Maza, M. (1999). Guion para cine, radio y televisión. México: Pearson Education, 280.

Naumis Peña, C (2009). Memorias del I Simposio Internacional sobre Organización del Conocimiento: Bibliotecología y Terminología. México: cuib

Newman, N. y D. Levy (2014). Reuters Institute Digital News Report 2014 - Tracking the Future of News. Oxford: Reuters Institute for the Study of Journalism, University of Oxford.

Páramo, J.A. (2002). Diccionario Espasa Cine y TV. Terminología técnica. Madrid: Espasa, 560.

Richmond, S. (2008). "HOW SEO is changing journalism". British Journalism Review, 19 (4), 51-55.

Rodríguez Vázquez, A.G. (2016). Diccionario de Comunicación. México: unam.

Soto Hernández, Silvano y Catalina Naumis Peña (2014). "Análisis bibliotecológico de los noticieros televisivos mexicanos en la web”. El Profesional de la Información, 23 (1), 80-86.

Stabiner, K. (2011). "CJR Column Mentions The Simpsons. A Second Look at SEO”. Columbia Journalism Review. 


\title{
El textil tradicional como soporte de información. Su análisis y organización
}

\author{
Patricia Alejandra Méndez Zapata \\ Posgrado en Bibliotecología y Estudios de la Información \\ UNAM
}

En este huipil, llevo grabado todo lo que padecí y gocé en los primeros cuarenta años de mi vida. Estas seis flores rojas son los corazones de mis abuelas, de mi madre y de mis tres hermanas que ya murieron. Estos muñequitos son mis bijos, nueve que be tenido, y se distinguen los que no se han logrado porque llevan una planta de maiz, es decir, que ya se fueron a alimentar la tierra. Y vea usted esta greca para que se dé cuenta de lo difícil que ha sido mi vida, que hasta remolinos de llanto hay abí. Éste es mi ángel de la guarda, y éste otro es el demonio que me tienta. Los cocoles son mi marido, que como me abandonó nomás me la paso pensando en él. Éste es mi árbol de la vida y de la muerte, y yo estoy en su centro porque aqui ando cumpliendo mi destino. Ya voy a labrar otro huipil con más cosas que be vivido, y cuando me muera, me vestirán con los dos uno encima del otro. Cuando suba al cielo, nomás de verlos ya sabrá Dios de qué me ha de enjuiciar. 
INTRODUCCIÓN

T a palabra textil proviene del latín texere, que significa tejer. La palabra textil es definida de acuerdo con el diccionario de la Real Academia (DRAE) como "perteneciente o relativo a los tejidos" o "dicho de una materia: Capaz de reducirse a hilos y ser tejida”. Es común encontrar esta definición en textos que tratan el tema, aunque también en no pocas ocasiones encontramos el término "industria textil" o "tejido" debido principalmente a la relación tan estrecha que existe entre éstos; sin embargo, para efectos del presente documento, utilizaremos el término textil para referirnos a la vestimenta $y$, en específico, la vestimenta que ha sido elaborada de manera artesanal, con técnicas tradicionales de hilado, urdido y tejido, principalmente en los pueblos indígenas.

En este sentido, es importante mencionar que el término tradicional remite al valor que de manera colectiva se le ha dado a algo y que es transmitido de generación en generación, "implica un grupo de prácticas, normalmente gobernadas por reglas aceptadas abierta o tácitamente y de naturaleza simbólica o ritual que buscan inculcar determinados valores o normas de comportamiento por medio de su repetición, lo cual implica automáticamente continuidad con el pasado" (Hobsvawm, 2002: 8). Es decir, la tradición implica dar continuidad a costumbres, saberes y experiencias que se tienen, se transmiten de generación en generación y que le dan identidad a un grupo, los cuales en conjunto conforman lo que se denomina conocimiento tradicional.

El conocimiento tradicional, de acuerdo con la Unesco (2006), es el "conjunto acumulado y dinámico del saber teórico, la experiencia práctica y las representaciones que poseen los pueblos con una larga historia de interacción con su medio natural. La posesión de esos conocimientos, que están 
estrechamente vinculados al lenguaje, las relaciones sociales, la espiritualidad y la visión del mundo, suele ser colectiva". Por tanto, podemos considerar que un textil adquiere su valor de tradicional a partir de que es parte del patrimonio cultural de un pueblo y de su identidad. De acuerdo con Alejandro González (2014: 10), "decir que los textiles son tradicionales significa usar una poderosa estrategia social para asegurar que es valioso, que habla elocuentemente acerca de quienes elaboran los materiales".

La elaboración de textiles es parte de las tradiciones de diversos pueblos indígenas, es un símbolo de identidad, una herencia que va pasando de generación en generación y aunque no es una actividad exclusiva del género femenino, son las mujeres quienes, en la mayoría de los casos, tejen y además portan los textiles. En ellos se va plasmando información (implícita o explícitamente) que hace que sean portadores de historias, "los textiles son fuentes de información para obtener datos sobre sus creadores, de sus historias míticas y la forma en que ven el mundo"(idem), y esto es lo que hace que los textiles sean utilizados y puedan ser considerados soportes de información, en tanto que un soporte de información es "cualquier medio sobre el que se ha registrado información escrita, impresa o grabada o es apto para registrarla [...]" (García, 2000: 411).

Desde épocas antiguas, el ser humano ha utilizado diversos soportes para plasmar información en la búsqueda de trascender o dar a conocer algo. Encontramos entre éstos las piedras talladas, madera tallada o papel caligrafiado. Éste es el caso de los lienzos o telas utilizados por los pueblos indígenas de Mesoamérica para plasmar y transmitir información, a través de los cuales ha sido posible conocer o interpretar la historia, vida y costumbres de épocas determinadas. Para ello, los lienzos son sometidos a procesos específicos de 
análisis, en la mayoría de los casos de tipo arqueológico, en los que, a partir de categorías específicas, se ubica al objeto en un contexto a partir del cual puede ser estudiado.

En las ciencias de la información también se han generado metodologías desde las que es posible llevar a cabo procesos de análisis de objetos textiles, esto a partir de considerar los documentos susceptibles de ser sometidos a estudio.

ANÁLISIS TEXTIL

El término análisis, de acuerdo con el DRAE, hace referencia a la "distinción y separación de las partes de algo para conocer su composición”. Es un conjunto de operaciones que permiten identificar y por tanto representar un objeto.

En el área de la bibliotecología y las ciencias de la información, se utiliza el término análisis documental para definir "el complejo de operaciones que afectan al contenido y la forma de los documentos originales para transformarlos en otros documentos representativos de aquellos que facilitan al usuario su identificación precisa, su recuperación y su difusión" (Pinto Molina, 1992: 89). A través de esto, el objeto es llevado a un proceso de análisis-síntesis en donde por medio del análisis se observan las partes del objeto de estudio, y por medio de la síntesis se establecen las relaciones entre los componentes en la búsqueda de tener una representación del mismo.

Considerando esto, podemos definir análisis textil como el proceso de identificación de todos los elementos (internos y externos) que conforman el objeto para poder representarlo y dar acceso al mismo; es decir, es el estudio detallado de las piezas textiles con la finalidad de identificar los materiales, los procesos y las técnicas de elaboración, así como los símbolos y cualquier otro tipo de información vinculada. 
La metodología para llevar a cabo el proceso de análisis textil debe ser muy similar a la que se utiliza para realizar el análisis documental al nivel que se desee; es decir, hay que considerar el análisis externo para la descripción del objeto y el análisis interno para la identificación de elementos que tienen que ver con las maneras de recuperación de la información obtenida del proceso de análisis, como son las formas de indización y la elaboración de resúmenes.

En la literatura, es muy común encontrar casos de análisis textil, principalmente desde el punto de vista arqueológico. En ellos se estudian principalmente textiles antiguos de manera extensa y muy profunda, aplicando elementos químicos a los objetos en los que a simple vista es difícil identificar aspectos como la temporalidad, el tipo de materiales que lo constituyen, las técnicas de tejido, entre otras cosas.

Desde el punto de vista antropológico, también hay un considerable número de procesos de análisis textil, los cuales son muy similares a los realizados desde la arqueología. En éstos, se identifican las características del tejido, las dimensiones, el material de elaboración, las densidad de los hilos, los orillos, la cabecera y la juntura, las tramas de relleno, la técnica del tejido, el diseño de bordes, etcétera. Además, existe una norma que puede ser utilizada para ello, ésta es la Guía para la clasificación de los datos culturales o Guía Murdock.

Desde la bibliotecología, existen marcos normativos a partir de los cuales también es posible analizar los textiles. Entre éstos, podemos mencionar las Reglas de catalogación angloamericanas, que contienen normas para la descripción de diversos tipos de materiales, y el Cataloging Cultural Objects, una herramienta que busca normar los procesos de catalogación y clasificación de objetos culturales.

Ambas proponen la identificación de elementos que pueden describir al objeto y que permiten su representación. Ejemplos 
de éstos son el nombre de la pieza, el nombre de quien la elaboró, el lugar de procedencia, la fecha de elaboración, las dimensiones, los colores y las decoraciones. En la medida de lo posible, se debe contextualizar con un breve resumen y asignar descriptores para su recuperación.

Cada una de las normas antes mencionadas (Murdock, RCAA y CCO) contienen apartados o áreas específicas para la descripción de los textiles, mismos que se pueden ubicar y relacionar en el siguiente cuadro:

A partir de la revisión de cada uno de los apartados y de la naturaleza específica de los marcos antes mencionados, se pueden observar diversas categorías para realizar el análisis, las cuales pueden ser agrupadas de la siguiente manera:

\begin{tabular}{|l|l|l|}
\hline \multicolumn{1}{|c|}{ Guía Murdock } & \multicolumn{1}{|c|}{ RCAA 2 ed. } & \multicolumn{1}{c|}{ CCO } \\
\hline Vestido habitual & Título & Denominación del objeto \\
\hline $\begin{array}{l}\text { Adornos y atavíos, } \\
\text { pieles, tejidos y } \\
\text { manufacturas }\end{array}$ & Notas & Características físicas \\
\hline $\begin{array}{l}\text { Manufactura de } \\
\text { vestidos }\end{array}$ & Descripción física & Características físicas \\
\hline $\begin{array}{l}\text { Nombre del lugar } \\
\text { Lugar de } \\
\text { publicación }\end{array}$ & $\begin{array}{l}\text { Año de } \\
\text { publicación geográfica }\end{array}$ & $\begin{array}{l}\text { Información estilística, } \\
\text { cultural y cronológica }\end{array}$ \\
\hline Identificación & Tema & Clase \\
\hline Vestido & Notas & Descripción \\
\hline $\begin{array}{l}\text { Resumen de la } \\
\text { cultura }\end{array}$ & Descripción física & Características físicas \\
\hline $\begin{array}{l}\text { Manufactura de } \\
\text { vestidos }\end{array}$ & Descripción física & $\begin{array}{l}\text { Información estilística, } \\
\text { cultural y cronológica }\end{array}$ \\
\hline Adornos &
\end{tabular}

Cuadro 1. Fuente: Méndez Zapata (2012). 
1. Denominación: identificar la manera en que se nombra el textil.

2. Uso: conocer con qué fines está hecho.

3. Descripción física: reconocer las características físicas del textil (partes, tamaños, colores, etc.).

4. Relación con: identificar su relación con otras prendas.

5. Materiales: saber de qué materiales está hecho.

6. Lugar: identificar el lugar de origen y si tiene similitudes y/o diferencias con los textiles de otras regiones.

7. Tiempo: listar las etapas, el tiempo de elaboración y la temporalidad o las fechas de elaboración.

8. Técnicas y proceso de elaboración: saber los procedimientos que se siguen para elaborar el textil.

9. Iconografía: identificar los elementos y simbolismos existentes.

10. Contexto: identificar las circunstancias alrededor del textil.

Con la identificación de los elementos mencionados, es posible tener una descripción contextual completa del objeto, de manera que se puede contar con una representación lo más cercana posible a su realidad. En esta propuesta, se pueden identificar elementos incluidos en las diversas normas, pero que no necesariamente están incluidos en todas. Lo que se ha buscado es determinar los elementos que es importante tener en cuenta para la significación de un objeto textil.

Hay que resaltar que la categorización antes mencionada parte de las diez categorías aristotélicas para organizar el conocimiento: sustancia, cantidad, relación, cualidad, lugar, tiempo, posición, hábito, acción y pasión, las cuales también fueron utilizadas por Ranganathan para diseñar su sistema de clasificación facetado, el cual está basado en cinco categorías fundamentales: tiempo, espacio, energía, materia y personalidad. 


\section{Organización}

A partir del análisis que se haga a los textiles, se obtendrá una importante cantidad de datos, los cuales necesitarán ser normalizados para posteriormente ser recuperados. Actualmente, con el uso de las tecnologías en las unidades de información se han diseñado sistemas gestores en los que, es posible organizar la información para recuperarla con el uso de metadatos o etiquetados semánticos; sin embargo, es un tema que aún está siendo explorado.

En las unidades de información, se hace uso de catálogos de acceso público en línea (OPAC) en el mejor de los casos, y de repositorios digitales en los que es posible compilar los datos que se recuperan de los procesos de análisis de los textiles en las bibliotecas y/o museos en donde se cuenta con colecciones de este tipo. De esta manera, el acceso se resuelve de manera inmediata debido a que ambos funcionan en contextos web y así casi cualquier persona, en cualquier parte del mundo, podría tener acceso. Sin embargo, no siempre es así ya que para que esto sea posible, todas las personas requieren conocer las direcciones electrónicas de cada uno de los sistemas o del descubridor de la unidad de información (en caso de que tenga) para poder consultar los recursos, los cuales en algunos casos se encuentran dispersos.

En este sentido, se observa la importancia de contar con herramientas como las ontologías, taxonomías y tesauros, los cuales son modelos de dominio que se han utilizado para organizar y recuperar información; son formas de representar un campo o ámbito de conocimiento e incluyen una serie de términos especializados que pueden ser codificados para actuar en sistemas web.

Para la elaboración de dichos sistemas, existen metodologías ya definidas en donde, aplicando técnicas propias de la lingüística 
y en algunos casos de la documentación, expertos en el tema o bibliotecarios con conocimiento del mismo generan herramientas terminológicas con la finalidad de uniformar y, por tanto, recuperar mayores cantidades de información; sin embargo, en pocas ocasiones para la elaboración de dichas herramientas se toma en cuenta el punto de vista del usuario, aspecto que puede dar como resultado poca funcionalidad real debido a que los términos utilizados pueden ser desconocidos para los usuarios de la información (Méndez, 2015).

Por ello se propone crear sistemas a partir de llevar a cabo proyectos multidisciplinares en los que puedan involucrarse los trabajos, las sugerencias y las experiencias de informáticos, ingenieros de sistemas, bibliotecólogos, terminólogos y, para el caso específico de los textiles, museólogos, antropólogos, arqueólogos y personas estudiosas del tema; además, dar garantía de uso a partir de la consideración del contexto y la experiencia de las tejedoras.

Para la organización de la información del textil tradicional y la creación de un sistema que pueda dar acceso a ésta, se propone generar un sistema de clasificación multidimensional, el cual será modelado desde la teoría comunicativa de la terminología тст, de Teresa Cabré. El término multidimensionalidad hace referencia a los diversos niveles o facetas que conforman y/o desde los que puede ser observado algo, y la тст propone analizar las unidades terminológicas desde tres planos o dimensiones: un plano referencial, uno cognitivo y uno lingüístico que se desprenden de un corpus de especialidad. Para ello, será necesario tomar en cuenta documentación especializada, así como el punto de vista de estudiosos del tema y las tejedoras.

Después del diseño del sistema de clasificación y de los procesos de verificación y evaluación de la información 
plasmada, será necesario implementarlo en un soporte diseñado específicamente para organizar y recuperar conocimiento, el cual podrá ser integrado posteriormente en diversos sistemas de gestión de información, lo que permitirá normalizar la terminología utilizada en un dominio de conocimiento específico; esto se verá reflejado en un mayor acceso, y en la compartición y recuperación de recursos disponibles vía web.

Comentarios finales

Las propuestas de organización y análisis aquí descritas son parte de un proyecto que realizo actualmente, el cual surge de un particular interés por integrar en áreas como la organización de la información y el conocimiento, y la terminología, el caso de los textiles tradicionales; éste además es un buen pretexto para comenzar a hablar de la organización de objetos desde el área bibliotecológica.

Durante varios años de trabajo en descripción de arte popular, he podido encontrar un área a explorar en la que los bibliotecarios y/o gestores de información deberíamos colaborar. Es muy común observar, por la naturaleza de los materiales, a museógrafos y/o antropólogos llevar a cabo esta tarea; sin embargo, la formación que los bibliotecólogos recibimos como investigadores-documentalistas, nos ofrece la posibilidad de análisis de cualquier objeto; lo importante es explotar y explorar metodologías que nos permitan llevarlo a buen fin.

En el área de los textiles tradicionales, he podido identificar, a partir de los diversos procesos de análisis que he realizado, una gran cantidad de información que en pocas ocasiones es reconocida. Los textiles tradicionales suelen 
ser vistos desde lados "románticos" como las vestimentas hermosamente elaboradas por mujeres bellamente ataviadas que mueven sus manos de manera armónica entre los hilos y los telares, pero perdemos de vista el lado humano y contextual a partir del cual son elaboradas, una perspectiva que no quitaría del textil el lado poético pero que nos permitiría entender la cosmovisión, historia y geografía que también dan identidad a un pueblo.

Cuando admiramos la indumentaria tradicional de diversas regiones de México y otros países, solemos enfocarnos en las prendas tejidas localmente. Nos llaman la atención las fibras procesadas a mano, al igual que los tintes extraídos de plantas y animales con los que convive determinado grupo humano. Muchas veces idealizamos los textiles artesanales como expresiones de un equilibrio saludable entre las comunidades preindustriales y su entorno natural (Alejandro de Ávila). 


\section{Bibliografía}

Ávila, A. (2013). Plata, vidrio y algodón: reflejos de la ciudad en los atuendos indigenas de Oaxaca. Disponible en: bit.ly/2uQeRma.

García Ejarque, L. (2000). Diccionario del archivero bibliotecario: terminología de la elaboración, tratamiento y utilización de los materiales propios de los centros documentales. Madrid: Trea.

Gaspa,S. A Study on the Terminology and the Material Culture of the Textiles in the Neo-Assyrian Empire. Recuperado de bit.ly/2wy1938.

González, V.A. (2014). Cambio y continuidad en las organizaciones indígenas textiles femeninas: Del capital social a la tradición textil. México: Dirección General de Culturas Populares.

Hobsbawm, E. y T. Ranger (2002). La invención de la tradición. Barcelona: Crítica.

Johnson, K. (2015). Saberes enlazados: la obra de Irmgard Weitlaner Johnson. México: Artes de México.

Méndez Zapata, P.A. (2015). Clasificación lingüística multidimensional del textil tradicional indígena. Protocolo de investigación.

Pinto Molina, M. (1992). El resumen documental: principios y métodos. Madrid: Pirámide.

Unesco. (2006). Conocimientos tradicionales. París. Disponible en: http://megaslides.es/doc/453649/conocimientos-tradicionales.

Weber, M. (1992). Economía y sociedad: esbozo de sociología comprensiva. México: FCE. 


\title{
Organización de la colección \\ fílmica del programa \\ Archivo Memoria \\ de la Cineteca Nacional
}

\author{
Hilda Gabriela lobatón Cruz \\ Cineteca Nacional de México
}

\section{INTRODUCCIÓN}

71 cine surgió como un medio de distracción para la clase alta que presentaba al público un nuevo espectáculo. Con el paso del tiempo, este espectáculo fue consolidándose hasta ser considerado el "séptimo arte".

La cinematografía ha sido considerada mayormente un objeto comercial o cultural en el campo del ocio y el entretenimiento; sin embargo, con el surgimiento de la sociedad de la información y el conocimiento, y el mayor acceso a las redes informáticas, se ha transformado en una gran fuente de contenidos que puede ofrecer de forma inmediata información para tareas generales o específicas, así como para la difusión y la divulgación. En este sentido, se destaca la necesidad de otorgarle a los materiales fílmicos un rol primordial, puesto que al igual que los materiales impresos, son un testimonio de la historia de la humanidad.

En la era de la información, las imágenes en movimiento son uno de los soportes primarios de la memoria colectiva, 
así como una fuente básica de la documentación histórica. La difusión de documentos fílmicos es muy descuidada. La misión de estos archivos no sólo es conservar estos soportes sino darlos a conocer, ya que su esencia es la conservación para su futura difusión.

\section{ORGANIZACIÓN Y NORMALIZACIÓN \\ EN LOS ARCHIVOS FÍLMICOS}

A nivel mundial, se logró normalizar desde 1970 la catalogación de las imágenes en movimiento con las Reglas de Catalogación de la FIAF para Archivos Fúlmicos. En algunos archivos, se creó una metodología que tendía a realizar una descripción de contenido más detallada para poder hacer frente a las demandas de los investigadores que solicitan planos, tomas o secuencias específicas.

Estas normas, desarrolladas para permitir el uso de un lenguaje común, orientado hacia los procesos de catalogación y clasificación de los documentos fílmicos, nos sirven para realizar no sólo la descripción integral del documento, sino una eficaz recuperación de la información.

Con el análisis documental, se inicia la identificación y descripción de la obra o documento; forma y contenido son las dos referencias de este proceso y ambas interactúan en la dinámica de la creación constante de nuevas formas documentales.

Según Alfonso López Yépez (apud. Clausó García, 1993: 13), el análisis documental se define como:

El conjunto de operaciones que permiten desentrañar del documento la información contenida en él. El resultado de esta metamorfosis, que el documento sufre en manos del documentalista, 
culmina cuando la información "liberada" se difunde y se convierte en fuente selectiva de información. Entonces el mensaje documentado se hace mensaje documental, información actualizada. Los dos polos que concretan su campo de actuación son el análisis formal y el análisis de contenido.

Si adaptamos la definición anterior al análisis de documentos fílmicos, se constata que en el proceso de valoración de estos fondos se deben contemplar tanto la descripción sintética de la obra (catalogación), como la descripción de las secuencias o de los planos (análisis de contenido) para mantener la integridad del documento.

Así, cuando nos encontramos frente a un documento fílmico, por ejemplo, un documental o una película de ficción en formato cinematográfico, el cual es una composición de varios planos o de un plano secuencial, éste es susceptible de ser investigado por el usuario a dos niveles: el todo o la parte; es decir, la obra en sí misma o un extracto de esa obra, lo que hace necesario una doble descripción: la catalogación, que implica una síntesis o resumen de conjunto de la obra por un lado, y la descripción de contenido específica de secuencias o de planos por otro.

ORgANiZACión DE LA COLECCIÓN

fílmica del programa ArChivo Memoria

\section{Archivo Memoria}

Desde 1983, un año después del incendio de la primera sede de la Cineteca Nacional, se recibió un gran número de donaciones por parte de la comunidad cinematográfica. Estas donaciones incluían desde material en $35 \mathrm{~mm}$ de títulos de exhibición comercial, hasta material de cine casero 
en 16mm. Las películas "caseras" fueron almacenadas en una bóveda sin registro alguno. Fue hasta el 2010 que se comenzó un proyecto de rescate de "películas huérfanas" (anteriormente llamadas "películas caseras") con la intención de hacerlas accesibles al público. Una "película huérfana” es, en su concepción más estrecha, una película que ha sido abandonada por su dueño. En términos generales, se trata de cualquier película que exista fuera del espectro comercial y que ha sido descuidada, escondida o es única. De la suma de imágenes puestas en una película a lo largo del siglo pasado, sólo un porcentaje reducido ha formado el estrecho canon de largometrajes que usualmente son vistos como la Historia del cine. Pero la historia de la imagen en movimiento está hecha, también, de lo "no visto": tráileres, cine casero, películas amateurs, materiales censurados, cine educacional, obra experimental, pruebas de cámara, material de archivo, animaciones, pietaje y otros fragmentos efímeros. Actualmente, la Cineteca Nacional cuenta con un programa de donación para los interesados en legar este tipo de películas.

El programa Archivo Memoria está diseñado para preservar las imágenes que conforman nuestra memoria social y generar consciencia sobre su importancia a través de un amplio programa de preservación y acceso. Más allá de "salvar" las películas huérfanas, el proyecto tiene el objetivo de la creación: se conciben las actividades del archivo como un medio para crear nuevos conocimientos y nuevos proyectos creativos a través de la reutilización de estas imágenes en movimiento.

En la actualidad, el Archivo Memoria está conformado por cerca de cinco mil rollos de película que se encuentran en formatos como $16 \mathrm{~mm}, 9.5 \mathrm{~mm}, 8 \mathrm{~mm}$ y súper $8 \mathrm{~mm}$ (Cineteca Nacional, 2016). 


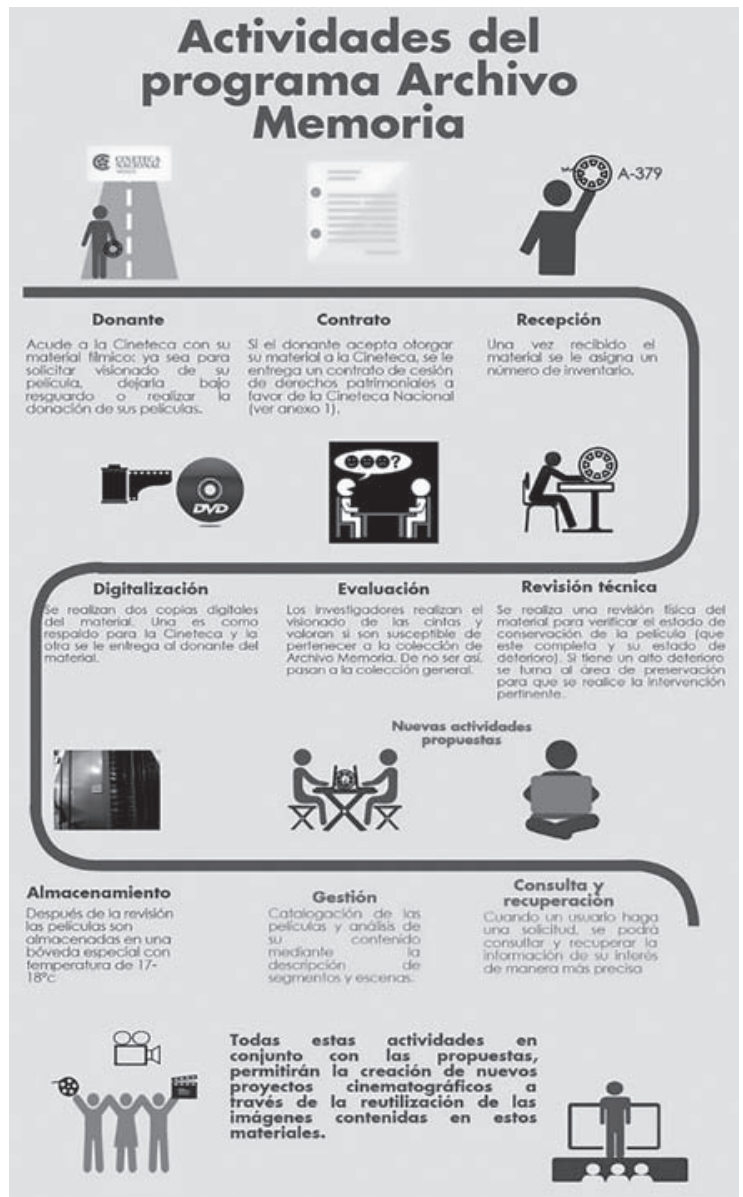

Imagen 1. Actividades del programa Archivo Memoria.

En los archivos fílmicos, la organización de la información se inicia con dos pasos esenciales que son el inventario y la verificación técnica de cada uno de los elementos que componen las unidades documentales visuales. Estos procesos permiten extraer la información fundamental sobre las características físicas del documento y los datos de los créditos que se incluirán dentro del catálogo. Para llevarlos a cabo, es necesario: 
1. Conocer el lenguaje de la imagen en movimiento para poder identificar y describir los elementos de la realidad visual y sus técnicas, asimismo, la diversidad de géneros en que se manifiesta su creación. 2. Identificar cada una de las áreas que componen la descripción catalográfica y de contenido que permiten estructurar la metodología adecuada para el análisis documental de la imagen en movimiento: visualizar, resumir e indizar, para un uso general o de extractos de la obra.

3. El diseño o aplicación de software de bases de datos que permitan de manera sistemática, flexible, interactiva y rápida la recuperación de la información contenida en esta clase de documentos. En este caso, se utiliza el software libre Koha.

Los esquemas de catalogación presentados a continuación se basan en las Reglas de Catalogación de la FIAf, adaptación que realizó la Comisión de Catalogación de la fiaf sobre las ISBD-NBM para satisfacer las necesidades específicas de recuperación de la información en archivos fílmicos. Las Reglas están diseñadas como una guía para la preparación de registros catalográficos que posibiliten el intercambio de información filmográfica universalmente. Para los metadatos, se utilizará el formato MARC21 junto con las AMIM2 (Archival Moving Image Materials), que retoma los campos MARC destinados a documentos audiovisuales. La plantilla inicial para la descripción de la película (como un todo) se presenta a continuación en un cuadro basado en los acuerdos de catalogación entre los archivos fílmicos mexicanos del programa Ibermedia "Catálogo Colectivo de Archivos fílmicos de Latinoamérica, el Caribe y España”. 


\begin{tabular}{|c|c|c|c|}
\hline $\begin{array}{l}\text { Etiqueta } \\
\text { MARC21 }\end{array}$ & Nombre etiqueta & $\begin{array}{c}\text { Indicadores / } \\
\text { subcampos MARC1 }\end{array}$ & $\begin{array}{l}\text { Ejemplo de } \\
\text { catalogación }\end{array}$ \\
\hline LD05 & Estado del registro & $\mathrm{n}$ - Nuevo & $\mathrm{N}$ \\
\hline LD06 & Tipo de registro & g-Medio proyectable & G \\
\hline LD07 & Nivel bibliográfico & m - Monografía/Ítem & $M$ \\
\hline LD08 & Tipo de control & \# - Indefinido & \# \\
\hline LD09 & $\begin{array}{l}\text { Esquema de la codificación } \\
\text { de caracteres }\end{array}$ & \# - MARC8 & \# \\
\hline Cabecera 10 & Conteo de indicadores & Generado por el sistema & \\
\hline Cabecera 11 & $\begin{array}{l}\text { Conteo del código de } \\
\text { subcampo }\end{array}$ & Generado por el sistema & \\
\hline Cabecera 12-16 & $\begin{array}{l}\text { Dirección base para los } \\
\text { datos }\end{array}$ & Generado por el sistema & \\
\hline LD17 & Nivel de codificación & $\begin{array}{l}5 \text { - Nivel parcial (preli- } \\
\text { minar) }\end{array}$ & 5 \\
\hline LD18 & $\begin{array}{l}\text { Forma de la catalogación } \\
\text { descriptiva }\end{array}$ & \# - Non-ISBD & \# \\
\hline LD19 & $\begin{array}{l}\text { Nivel del registro en partes } \\
\text { múltiples }\end{array}$ & \# - No especificado & \# \\
\hline Cabecera 20 & $\begin{array}{l}\text { Longitud de la porción de } \\
\text { la longitud de campo }\end{array}$ & Generado por el sistema & \\
\hline Cabecera 21 & $\begin{array}{l}\text { Longitud de la porción del } \\
\text { carácter de inicio }\end{array}$ & Generado por el sistema & \\
\hline Cabecera 22 & $\begin{array}{l}\text { Longitud de la porción de } \\
\text { implementación }\end{array}$ & Generado por el sistema & \\
\hline Cabecera 23 & $\begin{array}{l}\text { Posición de carácter indefi- } \\
\text { nida de mapa de entrada }\end{array}$ & Generado por el sistema & \\
\hline 001 & Número de control & Generado por el sistema & \\
\hline $\begin{array}{l}\text { 008 Campos de } \\
\text { datos variables } \\
00-05\end{array}$ & $\begin{array}{l}\text { Fecha de ingreso del } \\
\text { registro }\end{array}$ & $\begin{array}{l}\text { Se genera automática- } \\
\text { mente según este patrón: } \\
\text { aammdd }\end{array}$ & 151204 \\
\hline 008-06 & $\begin{array}{l}\text { Tipo de fecha/Estado de } \\
\text { publicación }\end{array}$ & $\begin{array}{l}\text { n - Fecha desconocida } \\
\text { s - Unica fecha conocida, } \\
\text { fecha probable }\end{array}$ & $S$ \\
\hline 008-07 10 & Fecha 1 & $\begin{array}{l}\text { Año de producción } \\
1-9 \text { - Dígitos de la fecha }\end{array}$ & 1995 \\
\hline 008-11 14 & Fecha 2 & $\begin{array}{l}\text { Año de producción } \\
\text { 1-9 - Dígitos de la fecha }\end{array}$ & $\# \# \#$ \\
\hline 008-15 17 & $\begin{array}{l}\text { Lugar de publicación, pro- } \\
\text { ducción o ejecución }\end{array}$ & $\begin{array}{l}\text { Lista de códigos MARC } \\
\text { para países }\end{array}$ & Mx (México) \\
\hline $\begin{array}{l}\text { 008-18-20-VM } \\
\text { (Visual Materials) }\end{array}$ & $\begin{array}{l}\text { Tiempo de duración de pe- } \\
\text { lículas y videograbaciones }\end{array}$ & $\begin{array}{l}000 \text { - Tiempo de ejecu- } \\
\text { ción que excede tres } \\
\text { caracteres }\end{array}$ & 025 \\
\hline
\end{tabular}




\begin{tabular}{|c|c|c|c|}
\hline $\begin{array}{l}\text { Etiqueta } \\
\text { MARC1 }\end{array}$ & $\begin{array}{l}\text { Nombre eti- } \\
\text { queta }\end{array}$ & $\begin{array}{c}\text { Indicadores / } \\
\text { subcampos MARC1 }\end{array}$ & $\begin{array}{l}\text { Ejemplo } \\
\text { de catalo- } \\
\text { gación }\end{array}$ \\
\hline & & $\begin{array}{l}\text { 001-999 - Tiempo de ejecución } \\
\text {--- Tiempo de ejecución desconocido } \\
\text { nnn - No aplicable } \\
\text { ||| - No se codifica }\end{array}$ & \\
\hline $008-22$ & Audiencia & | - No se codifica & | \\
\hline $008-23-27$ & No definidos & \|\|$\|$ - No se codifica & \|\||| \\
\hline $008-28$ & $\begin{array}{l}\text { Publicación gu- } \\
\text { bernamental }\end{array}$ & | - No se codifica & | \\
\hline $000-29$ & $\begin{array}{l}\text { Forma del ma- } \\
\text { terial }\end{array}$ & | - No se codifica & | \\
\hline 008-30-32 & No definidos & || - No se codifica & $\|$ \\
\hline 008-33 & $\begin{array}{l}\text { Tipo de material } \\
\text { visual }\end{array}$ & m - Película & M \\
\hline $\begin{array}{l}008-34-\mathrm{VM} \\
\text { (Visual } \\
\text { Materials }\end{array}$ & Técnica & $\begin{array}{l}\text { a - Animación } \\
\text { c - Animación y live action } \\
1 \text { - Live action } \\
\text { n - No aplicable } \\
\text { u - Desconocido } \\
\text { z - Otra técnica } \\
\text { | - No se codifica }\end{array}$ & $\begin{array}{l}\mathrm{L} \text { (Live } \\
\text { action) }\end{array}$ \\
\hline $008-35-37$ & Idioma & Lista de códigos MARC para idiomas & spa (Español) \\
\hline $008-38$ & $\begin{array}{l}\text { Registro modifi- } \\
\text { cado }\end{array}$ & | - No se codifica & 1 \\
\hline 008-39 & $\begin{array}{l}\text { Fuente de catalo- } \\
\text { gación }\end{array}$ & d - Otra & $\mathrm{D}$ \\
\hline 024 & $\begin{array}{l}\text { Otros números o } \\
\text { códigos normali- } \\
\text { zados }\end{array}$ & $\begin{array}{l}\text { Primer indicador } \\
77-\text { Fuente especificada en subcampo } \\
\$ 2 \\
\text { Segundo indicador } \\
\#-\text { Indefinido } \\
\text { Subcampos } \\
\text { \$a) - Número estandarizado o código } \\
(\$ 2) \text { Fuente, número o código }\end{array}$ & $\begin{array}{c}{[7 \mid \#]} \\
(\$ a) 18400 \\
\text { (\$2) Expe- } \\
\text { diente de } \\
\text { Cineteca } \\
\text { Nacional }\end{array}$ \\
\hline 035 & $\begin{array}{l}\text { Número de con- } \\
\text { trol de sistema de } \\
\text { procedencia }\end{array}$ & $\begin{array}{l}\text { (Expediente de Cineteca Nacional) } \\
\text { Primer indicador } \\
\text { \# - Indefinido } \\
\text { Segundo indicador } \\
\text { - Indefinido: Subcampos } \\
\text { mero de control de sistema }\end{array}$ & $\begin{array}{c}{[\# \mid \#]} \\
(\$ a) 1895\end{array}$ \\
\hline 040 & $\begin{array}{l}\text { Fuente de catalo- } \\
\text { gación }\end{array}$ & $\frac{\text { Primer indicador }}{\# \text { - Indefinido }}$ & \\
\hline
\end{tabular}




\begin{tabular}{|c|c|c|c|}
\hline $\begin{array}{l}\text { Etiqueta } \\
\text { MARC1 }\end{array}$ & $\begin{array}{c}\text { Nombre eti- } \\
\text { queta }\end{array}$ & $\begin{array}{c}\text { Indicadores / } \\
\text { subcampos MARC1 }\end{array}$ & $\begin{array}{l}\text { Ejemplo } \\
\text { de catalo- } \\
\text { gación }\end{array}$ \\
\hline & & $\begin{array}{l}\text { Segundo indicador } \\
0 \text { - Caracteres no indizables } \\
\text { Subcampos } \\
\text { (\$a) Título } \\
\text { (\$h) Medio } \\
\text { (\$c) Mención de responsabilidad }\end{array}$ & $\begin{array}{l}\text { (\$a) El apar- } \\
\text { tamento } \\
(\$ \mathrm{~h})[\text { Obra } \\
\text { audiovi- } \\
\text { sual]/ } \\
\text { (\$c) Gilles } \\
\text { Mondet } \\
\text { García }\end{array}$ \\
\hline 246 & Variantes de título & $\begin{array}{l}\text { Primer indicador } \\
0-\text { Nota, no se añade entrada } \\
\text { Segundo indicador } \\
3-\text { Otro título } \\
\text { Subcampos } \\
\text { (\$a) Título, título corto }\end{array}$ & \\
\hline 264 & $\begin{array}{l}\text { Publicación, dis- } \\
\text { tribución, etc. }\end{array}$ & $\begin{array}{l}\text { Primer indicador } \\
\text { \# - No se proporciona información } \\
\text { Segundo indicador } \\
\text { 0 - Producción } \\
\text { Subcampos } \\
\text { (\$a) - Lugar de producción } \\
(\$ b) \text { - Nombre del productor } \\
(\$ c) \text { - Fecha de producción }\end{array}$ & $\begin{array}{l}{[\# \mid 0]} \\
\text { (\$a) México: } \\
\text { (\$b) Gilles } \\
\text { Mondet } \\
\text { García, (\$c) } \\
1995\end{array}$ \\
\hline 300 & Descripción física & $\begin{array}{l}\text { Primer indicador } \\
\text { \# - Indefinido } \\
\text { Segundo indicador } \\
\text { \# - Indefinido } \\
\text { Subcampos } \\
\text { (\$a) Duración, metraje: } \\
\text { (\$b) Emulsión, formato, paso de } \\
\text { banda; } \\
\text { (\$c) Dimensiones }\end{array}$ & $\begin{array}{l}{[\# \mid \#]} \\
(\$ a) 1 \\
\text { carrete de } \\
\text { película } \\
(25 \mathrm{~min} .) \\
185 \mathrm{~m} .: \\
(\$ \mathrm{~b}) \text { East- } \\
\text { mancolor, } \\
\text { Panorámico; } \\
(\$ \mathrm{c}) 35 \mathrm{~mm} .\end{array}$ \\
\hline 336 & $\begin{array}{l}\text { Tipo de conte- } \\
\text { nedor }\end{array}$ & $\begin{array}{l}\text { Primer indicador } \\
\text { \# - Indefinido } \\
\text { Segundo indicador } \\
\text { \#- Indefinido } \\
\text { Subcampos } \\
\text { (\$a) - Término del tipo de contenido }\end{array}$ & $\begin{array}{l}{[\# \mid \#](\$ a)} \\
\text { Imáge- } \\
\text { nes en } \\
\text { movimiento } \\
\text { bidimensio- } \\
\text { nales }\end{array}$ \\
\hline 490 & Mención de serie & $\begin{array}{l}\text { Primer indicador } \\
\#-\text { Trazado de serie } \\
\text { Segundo indicador } \\
\#-\text { Indefinido } \\
\underline{\text { Subcampos }} \\
\text { \$a) Título de serie, colección }\end{array}$ & \\
\hline
\end{tabular}




\begin{tabular}{|c|c|c|c|}
\hline $\begin{array}{l}\text { Etiqueta } \\
\text { MARC1 }\end{array}$ & $\begin{array}{c}\text { Nombre eti- } \\
\text { queta }\end{array}$ & $\begin{array}{c}\text { Indicadores / } \\
\text { subcampos MARC1 }\end{array}$ & $\begin{array}{c}\text { Ejemplo de catalo- } \\
\text { gación }\end{array}$ \\
\hline 500 & Nota general & $\begin{array}{l}\text { Primer indicador } \\
\# \text { - Indefinido } \\
\text { Segundo indicador } \\
\# \text { - Indefinido } \\
\text { Subcampos } \\
\text { (\$a) - Nota general }\end{array}$ & $\begin{array}{l}{[\# \mid \#]} \\
\text { (\$a) Seudónimos } \\
\text { (si es que los hubiera) }\end{array}$ \\
\hline 500 & Nota general & $\begin{array}{l}\text { Primer indicador } \\
\#-\text { Indefinido } \\
\text { Segundo indicador } \\
\#-\text { Indefinido } \\
\underline{\text { Subcampos }} \\
\$ \text { a) - Temas musicales }\end{array}$ & $\begin{array}{l}{[\# \mid \#] \text { (\$a) Música: Chase, }} \\
\text { Peter. Canciones: La } \\
\text { temps, - Davis, Jeff. -Az- } \\
\text { navour, Charles- - Charles } \\
\text { Aznavour. Same kind of } \\
\text { woman - Chase, Peter. } \\
\text { - Chase, Peter. }\end{array}$ \\
\hline 505 & $\begin{array}{l}\text { Nota de conte- } \\
\text { nido }\end{array}$ & $\begin{array}{l}\text { Primer indicador } \\
\text { \# - Indefinido } \\
\text { Segundo indicador } \\
\# \text { - Indefinido } \\
\text { Subcampos } \\
(\$ a) \text { - Contenido }\end{array}$ & \\
\hline 508 & Nota de créditos & $\begin{array}{l}\text { Primer indicador } \\
\# \text { - Indefinido } \\
\text { Segundo indicador } \\
\# \text { - Indefinido } \\
\text { Subcampos } \\
\text { (\$a) Créditos }\end{array}$ & $\begin{array}{l}{[\# \mid \#]} \\
\text { (\$a) Bruno Fernández } \\
\text { Vella (Técnico video } \\
\text { 1) Juan Carlos Martín } \\
\text { Alonso (Técnico video } \\
\text { 2) }\end{array}$ \\
\hline 511 & $\begin{array}{l}\text { Nota de partici- } \\
\text { pantes o intér- } \\
\text { pretes }\end{array}$ & $\begin{array}{l}\text { Primer indicador } \\
1 \text { - Elenco } \\
\text { Segundo indicador } \\
\# \text { - Indefinido } \\
\text { Subcampos }(\$ a) \text { - Intérpre- } \\
\text { tes: Nombre, alias, papel }\end{array}$ & $\begin{array}{l}1 \mid \#] \text { (\$a) Romance } \\
\text { Bohringer (Lisa), Tateo } \\
\text { Isaizaki (Max, Médico } \\
\text { cirujano), Schimizu Tsuyu } \\
\text { (Padre de Lisa), Ricardo } \\
\text { Mateo (Médico cirujano), } \\
\text { Vincent Nemeth (Barman) }\end{array}$ \\
\hline 511 & $\begin{array}{l}\text { Nota de partici- } \\
\text { pantes o intér- } \\
\text { pretes }\end{array}$ & & Intervenciones \\
\hline 511 & $\begin{array}{l}\text { Nota de partici- } \\
\text { pantes o intér- } \\
\text { pretes }\end{array}$ & & $\begin{array}{l}\text { Personajes de anima- } \\
\text { ción: personaje, voz del } \\
\text { personaje }\end{array}$ \\
\hline 518 & $\begin{array}{l}\text { Nota de fecha/ } \\
\text { hora y lugar de un } \\
\text { acontecimiento }\end{array}$ & $\begin{array}{l}\text { Primer indicador } \\
\# \text { - Indefinido } \\
\text { Segundo indicador } \\
\# \text { - Indefinido } \\
\text { Subcampos } \\
\text { (\$a) Fecha, hora, lugar }\end{array}$ & $\begin{array}{l}\# \mid \#] \\
(\$ a) \text { Estrenos, fecha } \\
\text { de inicio y fecha final } \\
\text { de rodajes, notas de } \\
\text { estreno }\end{array}$ \\
\hline
\end{tabular}




\begin{tabular}{|c|c|c|c|}
\hline $\begin{array}{l}\text { Etiqueta } \\
\text { MARC1 }\end{array}$ & $\begin{array}{l}\text { Nombre eti- } \\
\text { queta }\end{array}$ & $\begin{array}{c}\text { Indicadores / } \\
\text { subcampos MARC1 }\end{array}$ & $\begin{array}{c}\text { Ejemplo de cataloga- } \\
\text { ción }\end{array}$ \\
\hline 520 & $\begin{array}{l}\text { Nota de } \\
\text { sumario, etc. }\end{array}$ & $\begin{array}{l}\text { Primer indicador } \\
\text { finido } \\
\text { Segundo indicador } \\
\text { - Indefinido } \\
\text { Subcampos } \\
\text { (\$a)-Sinopsis }\end{array}$ & $\begin{array}{l}{[\# \mid \#](\$ a) \text { Max está a }} \\
\text { punto de } \\
\text { casarse, pero vive atra- } \\
\text { pado por un recuerdo. } \\
\text { Cree reconocer la voz } \\
\text { de Lisa, de quien estuvo } \\
\text { enamorado hace tiempo, } \\
\text { y sale a su encuentro. }\end{array}$ \\
\hline 520 & $\begin{array}{l}\text { Nota de suma- } \\
\text { rio, etc. }\end{array}$ & & Notas a sinopsis \\
\hline 522 & $\begin{array}{l}\text { Nota de ámbi- } \\
\text { to geográfico }\end{array}$ & $\begin{array}{l}\text { Primer indicador } \\
\text { finido } \\
\text { Segundo indicador } \\
\text { \#- Indefinido } \\
\text { Subcampos } \\
\text { (\$a) - Locaciones }\end{array}$ & $\begin{array}{l}{[\# \mid \#]} \\
\text { (\$a) México: Ciudad de } \\
\text { México }\end{array}$ \\
\hline 530 & $\begin{array}{l}\text { Nota de } \\
\text { formato físico } \\
\text { adicional dis- } \\
\text { ponible }\end{array}$ & $\begin{array}{l}\text { Primer indicador } \# \text { - Inde- } \\
\text { finido } \\
\text { Segundo indicador } \\
\text { \# - Indefinido } \\
\text { Subcampos } \\
\text { (\$a) - Notas de duración }\end{array}$ & $\begin{array}{l}{[\# \mid \#]} \\
(\$ a) \text { Notas a la duración }\end{array}$ \\
\hline 536 & $\begin{array}{l}\text { Nota de patro- } \\
\text { cinador }\end{array}$ & $\begin{array}{l}\text { Primer indicador } \# \text { - Indefinido } \\
\text { Segundo indicador } \\
\text { - Indefinido } \\
\text { Subcampos } \\
\text { (\$a) Subvenciones, finan- } \\
\text { ciación, notas a subvencio- } \\
\text { nes-financiación, otros datos } \\
\text { a subvencioes-financiación }\end{array}$ & $\begin{array}{l}{[\# \mid \#]} \\
\text { (\$a) Financiada por el } \\
\text { propio director }\end{array}$ \\
\hline 546 & $\begin{array}{l}\text { Nota de idio- } \\
\text { ma }\end{array}$ & $\begin{array}{l}\text { Primer indicador } \# \text { - Inde- } \\
\text { finido } \\
\text { Segundo indicador } \\
\text { - Indefinido } \\
\text { Subcampos } \\
\text { (\$a) - Nota de idioma }\end{array}$ & (\$a) En español \\
\hline 650 & $\begin{array}{l}\text { Temas gene- } \\
\text { rales }\end{array}$ & $\begin{array}{l}\text { Primer indicador } \\
\# \text { - No information provided } \\
0 \text { - No level specified } \\
1 \text { - Primary } \\
2 \text { - Secondary } \\
\text { Segundo indicador - Tesauro } \\
4-\text { Fuente no específicada } \\
\text { Subcampos } \\
\text { (\$a) Temas generales }\end{array}$ & \\
\hline
\end{tabular}




\begin{tabular}{|c|c|c|c|}
\hline $\begin{array}{l}\text { Etiqueta } \\
\text { MARC1 }\end{array}$ & $\begin{array}{l}\text { Nombre } \\
\text { etiqueta }\end{array}$ & $\begin{array}{c}\text { Indicadores / } \\
\text { subcampos MARC1 }\end{array}$ & $\begin{array}{c}\text { Ejemplo de catalo- } \\
\text { gación }\end{array}$ \\
\hline 653 & $\begin{array}{l}\text { Término de } \\
\text { indización - no } \\
\text { controlado }\end{array}$ & $\begin{array}{l}\text { Primer indicador } \\
\text { \# - No se proporciona información } \\
\text { Segundo indicador } \\
0-\text { Término general } \\
\text { Subcampos } \\
(\$ a)-\text { Término no controlado }\end{array}$ & $\begin{array}{l}{[\# \mid 0]} \\
(\$ a) \text { Ficción }\end{array}$ \\
\hline 655 & $\begin{array}{l}\text { Término de indi- } \\
\text { zación - Género/ } \\
\text { forma }\end{array}$ & $\begin{array}{l}\text { Primer indicador } \\
\#-\text { Básico } \\
\text { Segundo indicador } \\
\begin{array}{c}4-\text { Fuente no especificada } \\
\text { Subcampos }\end{array} \\
(\$ a)-\text { Longitud }\end{array}$ & $\begin{array}{l}{[\# \mid 4]} \\
\text { (\$a) Cortometraje }\end{array}$ \\
\hline 655 & $\begin{array}{l}\text { Término de indiza- } \\
\text { ción - Género/forma }\end{array}$ & Género & $\begin{array}{l}{[\# \mid 4]} \\
\text { (\$a) Romance }\end{array}$ \\
\hline 700 & $\begin{array}{l}\text { Encabezamiento se- } \\
\text { cundario - Nombre } \\
\text { de persona }\end{array}$ & $\begin{array}{l}\text { Primer indicador } \\
\text { 1-Entrada por apellido } \\
\text { Segundo indicador } \\
\text { 2- Entrada analítica } \\
\text { Subcampos } \\
(\$ a)-\text { Nombre }(\$ a) \text { - Función }\end{array}$ & $\begin{array}{l}{[1 \mid 2]} \\
(\$ a) \text { Nombre } \\
(\$ \mathrm{e}) \text { Director }\end{array}$ \\
\hline 700 & $\begin{array}{l}\text { Encabezamiento se- } \\
\text { cundario - Nombre } \\
\text { de persona }\end{array}$ & Productor & $\begin{array}{l}{[1 \mid 2](\$ a) \text { Nombre }} \\
(\$ e) \text { Productor }\end{array}$ \\
\hline 700 & $\begin{array}{l}\text { Encabezamiento se- } \\
\text { cundario - Nombre } \\
\text { de persona }\end{array}$ & Productor ejecutivo & $\begin{array}{l}{[1 \mid 2](\$ a) \text { Nombre }} \\
\text { (\$e) Productor eje- } \\
\text { cutivo }\end{array}$ \\
\hline 700 & $\begin{array}{l}\text { Encabezamiento se- } \\
\text { cundario - Nombre } \\
\text { de persona }\end{array}$ & Intérpretes & $\begin{array}{l}\text { [1|2] } \\
\text { (\$a) Apellidos, } \\
\text { Nombre } \\
\text { (\$e) Intérprete } \\
\text { (\$g) Papel }\end{array}$ \\
\hline 700 & $\begin{array}{l}\text { Encabezamiento se- } \\
\text { cundario - Nombre } \\
\text { de persona }\end{array}$ & & $\begin{array}{l}\text { Y así con el resto de } \\
\text { las personas implica- } \\
\text { das en la película }\end{array}$ \\
\hline 710 & $\begin{array}{l}\text { Encabezamiento se- } \\
\text { cundario - Nombre } \\
\text { de entidad }\end{array}$ & $\begin{array}{l}\text { Primer indicador } \\
\text { 2- Nombre en ordendirecto } \\
\text { Segundo indicador } \\
\# \text { - Indefinido } \\
\text { Productora }[2 \mid \#](\$ a)(\$ \mathrm{e})\end{array}$ & \\
\hline 710 & $\begin{array}{l}\text { Encabezamiento se- } \\
\text { cundario - Nombre } \\
\text { de entidad }\end{array}$ & $\begin{array}{l}\text { Productora en colaboración } \\
{[2 \mid \#](\$ a)(\$ \mathrm{e})}\end{array}$ & \\
\hline
\end{tabular}




\begin{tabular}{|c|c|c|c|}
\hline $\begin{array}{l}\text { Etiqueta } \\
\text { MARC1 }\end{array}$ & $\begin{array}{l}\text { Nombre } \\
\text { etiqueta }\end{array}$ & $\begin{array}{c}\text { Indicadores / } \\
\text { subcampos MARC1 }\end{array}$ & $\begin{array}{c}\text { Ejemplo de catalo- } \\
\text { gación }\end{array}$ \\
\hline 710 & $\begin{array}{l}\text { Encabezamien- } \\
\text { to secundario } \\
\text { - Nombre de } \\
\text { entidad }\end{array}$ & $\begin{array}{l}\text { Productora participante }[2 \mid \#] \\
(\$ a)(\$ \mathrm{e})\end{array}$ & \\
\hline 710 & $\begin{array}{l}\text { Encabezamien- } \\
\text { to secundario } \\
\text { - Nombre de } \\
\text { entidad }\end{array}$ & & $\begin{array}{l}{[2 \mid \#](\$ a) \text { En caso de }} \\
\text { que exista una produc- } \\
\text { tora en asociación }\end{array}$ \\
\hline 710 & $\begin{array}{l}\text { Encabezamiento } \\
\text { secundario - Nom- } \\
\text { bre de entidad }\end{array}$ & $\begin{array}{l}\text { Primer indicador } \\
2 \text { - Nombre en order directo } \\
\text { Segundo indicador } \\
\# \text { - Indefinido } \\
\text { Subcampos } \\
\text { (\$a)- Nombre de laboratorio } \\
\text { (\$e) - Si es o no el } \\
\text { laboratorio original }\end{array}$ & $\begin{array}{l}{[2 \mid \#]} \\
\text { (\$a) Fotofilm } \\
\text { (\$e) Laboratorio } \\
\text { original }\end{array}$ \\
\hline 710 & $\begin{array}{l}\text { Encabezamiento } \\
\text { secundario - Nom- } \\
\text { bre de entidad }\end{array}$ & & $\begin{array}{l}\text { Y así con el resto de } \\
\text { las personas implica- } \\
\text { das en la película }\end{array}$ \\
\hline 740 & $\begin{array}{l}\text { Entrada secun- } \\
\text { daria - Título } \\
\text { relacionado o } \\
\text { analítico no } \\
\text { controlado }\end{array}$ & $\begin{array}{l}\text { Primer indicador } \\
0-\text { Caracteres no indizables } \\
1-9-\text { Número de caracteres } \\
\text { no indizables } \\
\text { Segundo indicador } \\
\text { \#- No se proporciona información } \\
\text { Subcampos } \\
\text { (\$a) - Otros títulos originales }\end{array}$ & \\
\hline 856 & $\begin{array}{l}\text { Localización y } \\
\text { acceso electróni- } \\
\text { co (URL) }\end{array}$ & $\begin{array}{l}\text { Primer indicador - Método de } \\
\underline{\text { acceso }} \\
\# \text { - No proporciona información } \\
0 \text { - Email } \\
1 \text { - FTP } \\
2 \text { - Remote login } \\
\text { Segundo indicador - Relación } \\
\text { - No proporciona información } \\
0 \text { - Recurso } \\
1 \text { - Versión del recurso } \\
2 \text { - Recurso relacionado } \\
\text { Subcampos } \\
\text { (\$a) - Nombre del Host } \\
\text { (\$u) - Identificador uniforme } \\
\text { del recurso } \\
\text { (URL) } \\
\text { (\$q) - Tipo de formato elctrónico }\end{array}$ & \\
\hline
\end{tabular}


ANÁLISIS DE CONTENIDO

El análisis de contenido es importante por la variedad de temas abordados en los documentos fílmicos, pues ofrece diversidad de formas y temáticas que los hacen aptos para distintos modelos de explotación o utilización. De esta manera, se puede ofrecer a los investigadores en cinematografía nuevas fuentes documentales y a los creadores la reutilización de extractos en nuevas producciones. En el análisis de contenido, es indispensable principalmente para los materiales fílmicos el "visionado", que consiste en revisar la película fotograma por fotograma con el uso de una moviola para evitar una proyección innecesaria que pueda afectar la estabilidad de la cinta.

En la página siguiente, se presenta el modelo de análisis de contenido "por secuencia". Cabe destacar que posteriormente se contempla realizar el análisis cuadro por cuadro.

\section{Conclusiones}

Conservar y difundir el cine en toda su pluralidad es el objetivo principal de todo archivo fílmico. Es por ello que estas instituciones deben realizar mayores esfuerzos para promover y difundir el conocimiento y disfrute del cine en toda su diversidad y riqueza, y de esta manera contribuir a la construcción de la memoria audiovisual de la sociedad.

En su constante proceso de crecimiento, la Cineteca Nacional ha reconocido la necesidad de contribuir a la formación de usuarios activos y críticos ante el fenómeno audiovisual, para hacer del arte cinematográfico una experiencia al alcance de todos. Don esta propuesta se busca que con la gestión y el uso de esta colección se dé a conocer y se fomente la importancia de preservar y organizar la memoria contenida en imágenes en movimiento pertenecientes al patrimonio audiovisual de nuestro país. 
Organización de la colección fúlmica...

\begin{tabular}{|c|c|c|c|}
\hline 造 & 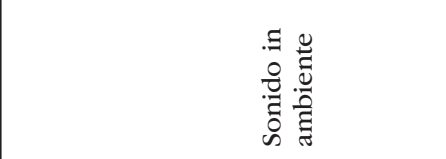 & & 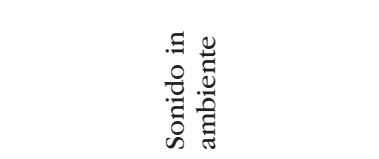 \\
\hline 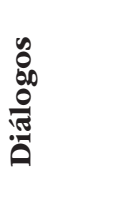 & 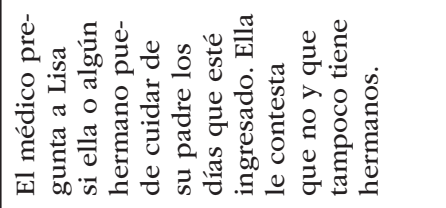 & & \\
\hline 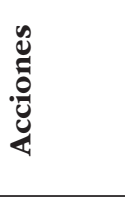 & 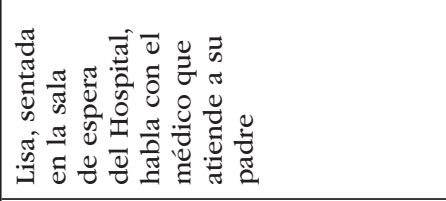 & & 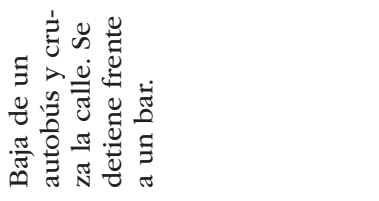 \\
\hline 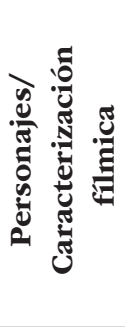 & 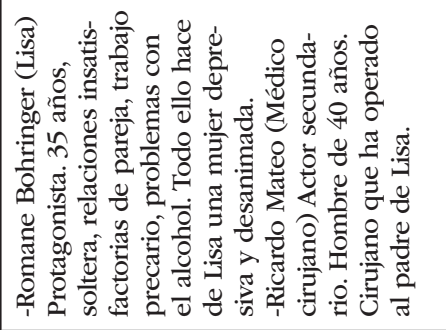 & 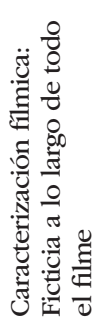 & 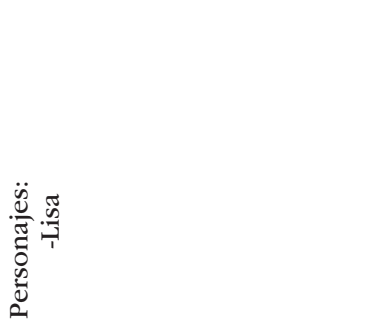 \\
\hline$\underset{\exists}{\mathfrak{g}}$ & 襡 & & 丞 \\
\hline 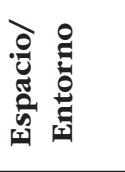 & 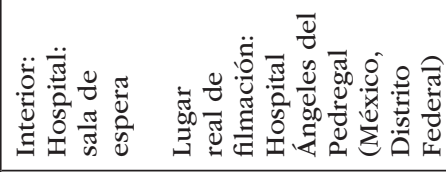 & & 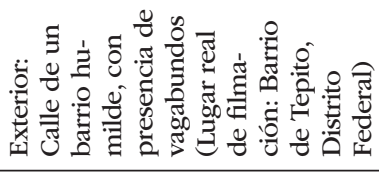 \\
\hline : & 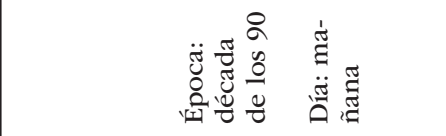 & & 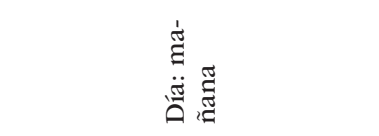 \\
\hline 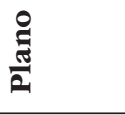 & 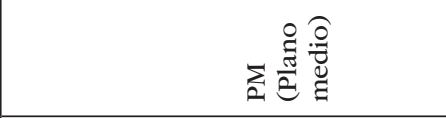 & & 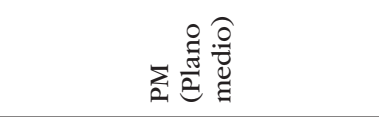 \\
\hline نू & 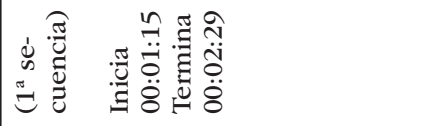 & & 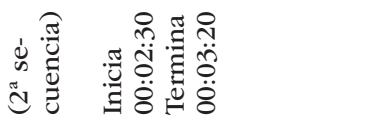 \\
\hline
\end{tabular}




\begin{tabular}{|c|c|c|c|}
\hline . & 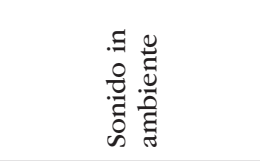 & 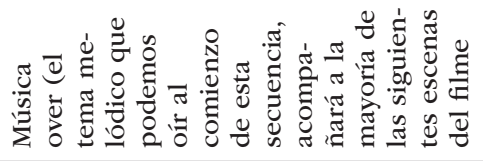 & 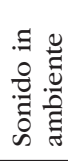 \\
\hline $\begin{array}{c}0 \\
0 \\
0 \\
0 \\
0 \\
0 \\
0\end{array}$ & 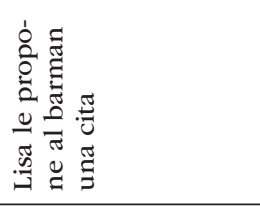 & 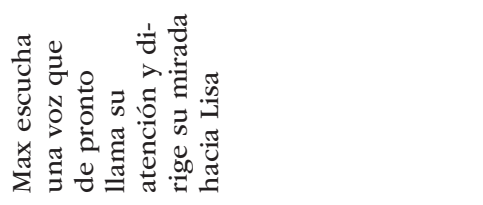 & \\
\hline$\frac{8}{\mathscr{0}}$ & 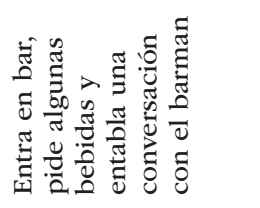 & 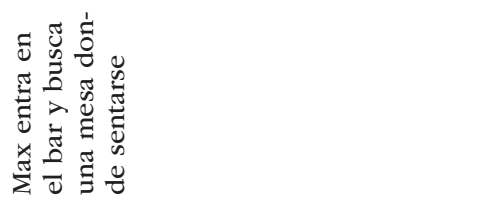 & \\
\hline 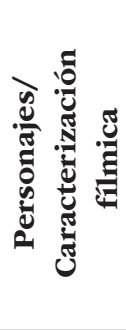 & 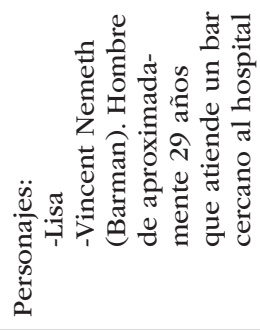 & 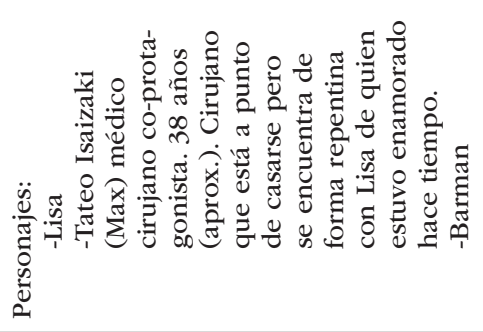 & \\
\hline$\stackrel{N}{3}$ & 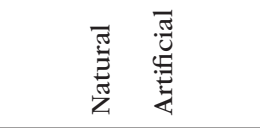 & 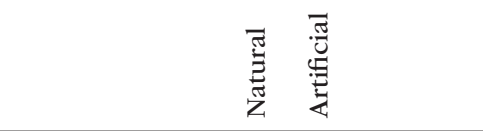 & \\
\hline 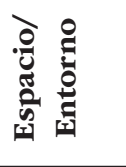 & 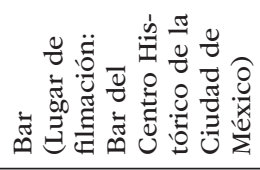 & 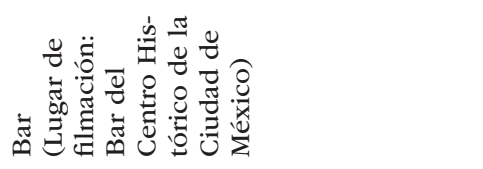 & \\
\hline$\stackrel{\circ}{\stackrel{E}{E}}$ & 苗茪 & 苗茪 & \\
\hline$\frac{8}{\stackrel{3}{2}}$ & 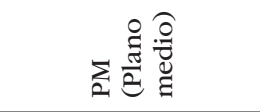 & 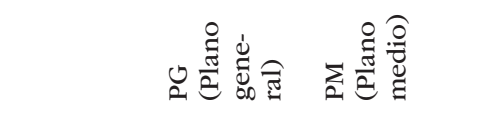 & \\
\hline \&્ల & 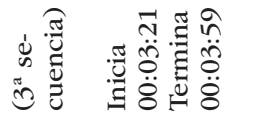 & 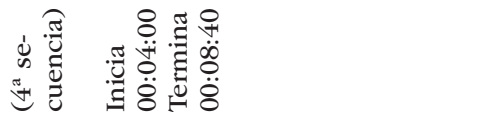 & \\
\hline
\end{tabular}


Organización de la colección fílmica...

\begin{tabular}{|c|c|c|c|}
\hline 导 & 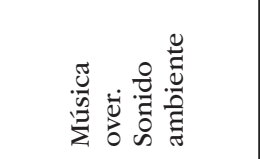 & 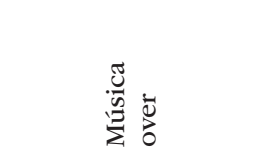 & 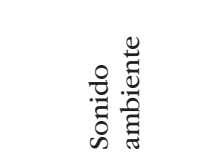 \\
\hline 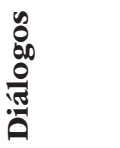 & & & \\
\hline$\frac{8}{d}$ & 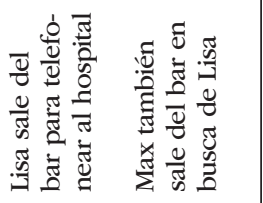 & 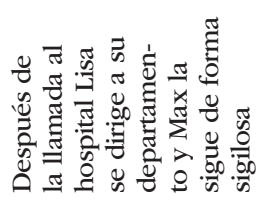 & 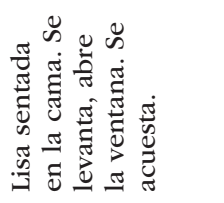 \\
\hline 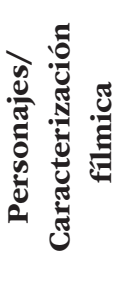 & 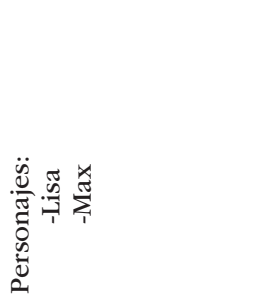 & 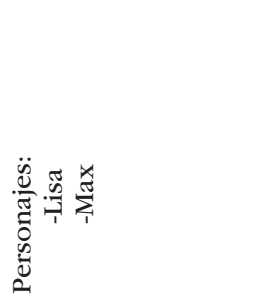 & 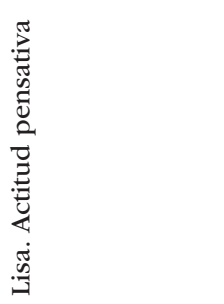 \\
\hline ב & 莺 & 苞 & 丞 \\
\hline 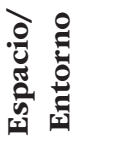 & 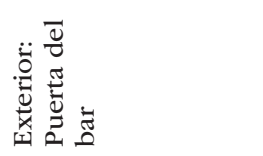 & 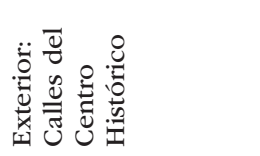 & 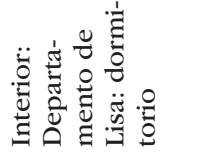 \\
\hline ֻٕ: & 茴 & 苗 & 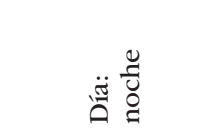 \\
\hline$\frac{\stackrel{0}{E}}{2}$ & 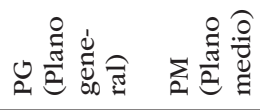 & $\begin{array}{l}\bigcup \\
2\end{array}$ & $\bigcup_{2} \quad \sum_{a}$ \\
\hline نं & 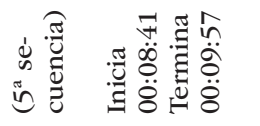 & 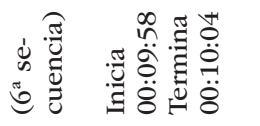 & 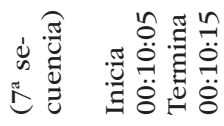 \\
\hline
\end{tabular}




\section{Bibliografía}

Cineteca Nacional (2016). Página de internet. Disponible el 29 de septiembre de 2016 en: http://www.cinetecanacional.net.

Clausó García, A. (2007). Manual de análisis documental. Pamplona: Eunsa.

Dávalos Orozco, F. (1993). Guía para la catalogación descriptiva de materiales audiovisuales. México: Dirección General de Bibliotecas, UNAM.

Espinal Arenas, L. (1989). Análisis y organización de materiales audiovisuales. Armenia: Universidad del Quindío.

Federación Internacional de Archivos Fílmicos (FIAF) (1998). Reglas de catalogación de la FIAF. Jorge Arellano Trejos (trad.). México: Archivo General de Puerto Rico / Filmoteca de la UNAM.

Federación Internacional de Asociaciones de Bibliotecarios y Bibliotecas (IFLA) (1993). Descripción Bibliográfica Internacional Normalizada para materiales no librarios. Madrid: Anabad / Arcolibros.

International Federation of Film Archives, Documentation Commission (1986). FIAF Classification Scheme for Literature on Film \& Television. Copenhague: FIAF.

Filmoteca Española (1983). Lista para temas de cine. Madrid: Filmoteca Española.

Fournial, C. (1986). "Análisis documental de imágenes en movimiento". En Panorama de los archivos audiovisuales. París: FIAT / IFTA / Unesco.

International Federation of Film Archives (FIAF) (2016). The FIAF Moving Image Cataloguing Manual. Bruselas: FIAF. (2001). Subject Headings Film ( $7^{\mathrm{a}}$ ed.). Bruselas: FIAF. 
Organización de la colección fúlmica...

(1991). The FIAF Cataloguing Rules for Film Archives. Múnich / Nueva York / París: FIAF.

Kula, S. (1983). La evaluación de las imágenes en movimiento de los archivos: un estudio del RAMP con directrices. París: Unesco.

Saavedra Bendito, P. (2011). Los documentos audiovisuales. Gijón: Trea. 


\section{El uso de la información en la alta gerencia}




\title{
La innovación en los servicios y el uso de la información en la alta gerencia
}

\author{
Ariel Alejandro Rodríguez García \\ Instituto de Investigaciones Bibliotecológicas y de la Información
}

UNAM

INTRODUCCIÓN

1 mensaje más importante que contiene este trabajo E es muy simple: las bibliotecas y los bibliotecólogos deben trabajar para innovar en los servicios, así como cambiar en su forma de pensar y actuar. En momentos en los que hay una infinidad de cambios "turbulentos", si se logra dominar y superar esas realidades, se gana. Si no se hace bien, se perderán oportunidades para posicionarse en ese mundo competitivo.

El reto que nos hemos propuesto para esta ocasión es tomar como punto de partida las cinco nuevas leyes de la bibliotecología propuestas por Gorman (1995: 784-785), 1) las bibliotecas sirven a la humanidad, 2) considerar todos los formatos por medio de los cuales el conocimiento es comunicado, 3) emplear la tecnología inteligentemente para dar realce a los servicios, 4) proteger el libre acceso al conocimiento y 5) honrar el pasado y crear el futuro. 
Las leyes no serán explicadas ni descritas, lo que deseamos hacer con éstas es contextualizarlas para entender por qué la innovación en los servicios, como es el caso de los sistemas de información gerencial y bibliotecológicos, deben mirar hacia el futuro y orientar los esfuerzos hacia un cambio a gran escala.

El bibliotecólogo tendrá que salir de su trinchera histórica de mediación instrumental y situarse en la visión de los nuevos usuarios-consumidores de información, quienes con su alta capacidad de autonomía sustentada por la tecnología se ubican como los creadores y consumidores de información.

\section{ENTORNO INTEGRAL}

Para comprender lo que queremos destacar sobre un entorno integral, nos guiaremos por los ocho pasos para un cambio exitoso a gran escala propuestos por Kotter y Cohen (2003): aumentar la urgencia; crear el equipo conductor; obtener la visión adecuada; comunicar para conseguir la aprobación; dar autoridad o responsabilidad para la acción; lograr pequeñas victorias a corto plazo; no abandonar; y hacer que el cambio prevalezca.

De estos ocho pasos, Kotter y Cohen indican que el problema más grave en todas las fases es cambiar el comportamiento de los individuos.

Para el bibliotecólogo que se encuentra envuelto en una profunda mezcla de tradiciones de más de un grupo disciplinar, hablar de innovaciones puede no ser muy claro. Por ejemplo, respecto a lo que se entiende por la innovación disruptiva, se tiene duda de si lo que se emprenderá es una reestructuración, retroalimentación o un reempaquetamiento en los servicios. 
En estos momentos de la información digital, el bibliotecólogo debe tener presentes tres aspectos fundamentales: su actualización permanente, que implica estar al tanto de las fluctuaciones económicas, ya que la sociedad está transitando a una economía basada en la innovación tecnológica que obliga a todos a orientar sus conocimientos y habilidades hacia el teletrabajo; el trabajo multitareas y la participación en grupos multidisciplinarios; y, finalmente, las labores encaminadas a diseñar actividades centradas en los usuarios.

Hay un aspecto que nos parece importante resaltar y es el que establece la diferencia entre la organización de la información en los sistemas bibliotecológicos y los sistemas de información gerencial. Al respecto, Glushko (2013) puntualiza que para la bibliotecología un sistema organizado es aquél que arregla intencionalmente las colecciones de recursos y la interacción entre éstas. Es decir, por mucho tiempo, los sistemas de información bibliotecológicos se han dedicado a la organización de objetos físicos como libros, hojas, mapas, CD, DVD, entre otros.

Mientras que los sistemas de información gerencial, señalan Laudon y Laudon (2012), son esenciales para realizar actividades comerciales diarias. Por ejemplo, las empresas de comercio electrónico no podrían vivir sin un sistema de información, debido a que hay una interdependencia cada vez mayor entre las habilidades de una empresa para usar las tecnologías de información y su destreza para implementar estrategias competitivas con el firme propósito de lograr sus objetivos corporativos.

Es suma, las empresas invierten mucho en sus sistemas de información gerencial con el único fin de lograr, según Laudon y Laudon (idem), sus seis objetivos de negocios estratégicos: excelencia operacional; nuevos productos, servicios 
y modelos de negocios; intimidad con los clientes y proveedores; toma de decisiones mejoradas; ventaja competitiva; y sobrevivencia.

Actualmente, las semejanzas y diferencias entre un sistema de información bibliotecológico y una gerencia no son demasiadas porque ambos se perfilan para ser competitivos con base en el uso de la información digital. De ahí que concordemos con Glushko (2013) cuando dice que debemos tomar el punto de vista transdisciplinar, el cual enfatiza que hay diferencias disciplinares pero que todas las disciplinas tienen un rasgo común. Por ejemplo, anteriormente se decía que las actividades de descripción bibliográfica y catalogación eran realizadas bajo la forma tradicional de organización, pero con la introducción del procesamiento automático de texto y la indización como parte de la disciplina de la organización de la información, se tuvo que cambiar hacia la interconexión de los sistemas para desarrollar una funcionalidad inteligente entre éstos.

El uso de la información en la alta gerencia y en la bibliotecología actualmente se ve como un elemento estratégico. Así lo indica Todaro (2014: 88) en sus nuevos y contemporáneos servicios y recursos, al referir que la administración de los servicios y recursos bibliotecarios debe modificar su administración externa, cambiar sus políticas y procedimientos; incrementar los modelos de presupuesto y financiamiento con el firme propósito de proporcionar nuevos servicios y recursos; balancear los materiales nuevos y clásicos, entre otros aspectos más.

La innovación en los servicios está siendo un asunto coyuntural en toda organización, y la biblioteca no es la excepción puesto que se enfrenta a nuevos entornos y retos que incitan a repensar qué servicios se están ofreciendo a comunidades que entre sus derroteros actuales se ven orilladas a depender en gran medida de las tecnologías. 
La cultura de la innovación está reconociendo que los procesos y las prácticas actuales son mejores que las anteriores y apostando a que los bibliotecólogos incorporen a sus nuevos roles una visión más abierta respecto a lo que se entiende por economía global (Rifkin, 2002), la cual se enfrenta a un nuevo mundo de símbolos, redes y bucles de retroalimentación.

Los nuevos saberes del bibliotecólogo le invitan a comprender que hay una nueva cultura económica, la estructura de la vida comercial ya no es tan simple y la reorganización de toda institución depende en gran medida de la tecnología. Es decir, se ha dejado atrás la economía basada en la industria por una economía sustentada por la tecnología de la información. Entonces, la innovación en los servicios se verá condicionada por la manera en que se comprendan tres aspectos fundamentales: la racionalización, reestructuración e intensificación del trabajo intelectual.

La práctica que siga el bibliotecólogo en este nuevo entorno dependerá de la apropiación de los conocimientos y habilidades tecnológicos, del entendimiento de ambientes de trabajo multirregional, del desprendimiento progresivo del trabajo visto como una obligación, del trabajo con horarios flexibles, y del rompimiento del paradigma de "vivir para trabajar" por el de "trabajar para vivir".

LAS DIMENSIONES DE LOS SISTEMAS

DE INFORMACIÓN BIBLIOTECOLÓGICO Y DE GERENCIA

La innovación varía según su tipo, como lo señalan King y Anderson (2003: 125). Existe aquélla que puede dirigirse al producto o proceso, aquélla que se orienta al servicio y aquélla otra que por naturaleza genera nuevos entornos. Por ejemplo, la innovación disruptiva acepta que la inno- 
vación tecnológica ha sustituido el paradigma que sostenía que las comunidades únicamente consumían información, por la idea de que ahora la abundante producción es almacenada en distintos formatos disponibles.

De ser así lo anterior, concordamos con lo que refieren Schmit y Cohen (2013: 30) sobre el entorno digital. A saber, que éste será más eficiente en la medida en que la conectividad digital llegue a los lugares más remotos del globo, y los nuevos usuarios la utilizarán para mejorar su amplia gama de mercados, sistemas y comportamientos. Si esta idea se contextualiza a un ámbito particular como es el bibliotecario, entonces la biblioteca habrá dejado de ser solamente un almacén con libros y pasará a ser una proveedora de servicios, y el bibliotecario-educador se convertirá en un bibliotecario disruptivo que se vuelve en protagonista por su nuevo liderazgo.

A partir de esta prospectiva, surge la iniciativa de desarrollar programas educativos orientados a facilitar el acceso y uso delos recursos de información digital, así como la perspectiva del transformador que al relacionarse con los miembros de su comunidad establece una simbiosis integral para hacer viables los esfuerzos institucionales.

Nos parece significativo mencionar la prioridad de los paradigmas de Kuhn (2007), quien señala que los nuevos profesionales deberán formarse y ejercer su oficio tomando en consideración el surgimiento de teorías novedosas. Es decir, el posicionamiento epistemológico en la preparación actual del bibliotecólogo no debe transitar de manera aislada al desarrollo de su entorno, porque de seguir así le estará dando la espalda a la realidad actual del mundo laboral y a las presentes y futuras comunidades a las que sirve.

En suma, los sistemas de información bibliotecológica en la actualidad se han transformado y apuntan a que no sólo 
es importante organizar los objetos físicos y recursos digitales, y el desarraigo comunitario no es la mejor manera de sobrevivir en un mundo competitivo. Lo que se espera de los sistemas de información bibliotecario es que interactúen con aquellos como los gerenciales puesto que, aunque sus roles y funciones difieren sustancialmente, no sólo deben atender intereses académicos, sino todos aquellos latentes e impuestos por el comercio electrónico, como lo refiere Shumaker (2012) en la descripción de las actividades del bibliotecólogo disruptivo. Otras actividades de este tipo de profesionistas son etiquetar contenidos, proveer alertas de novedades, recuperar nuevos conocimientos y ser investigador.

Ahora bien, la interrelación de estos sistemas de información a través de las tecnologías permite vislumbrar nuevos retos que promueven el aprendizaje en puntos clave con el fin de impulsar y, por qué no, adelantarse a la competencia.

\section{LA INFRAESTRUCTURA INTELIGENTE}

EN BENEFICIO DE LA ALTA GERENCIA

La industria 4.0, el Big Data, los datos vinculados, los servicios centrados en el usuario, entre otros aspectos, están propiciando que los procesos y las prácticas en la innovación de los servicios de las bibliotecas se reconfiguren en función de la revolución tecnológica.

No sólo los sistemas bibliotecarios, sino otros similares están proporcionando servicios de acuerdo con los cambios frecuentes suscitados en el campo computacional. Tales servicios paulatinamente están incorporando la tecnología basada en la web semántica (Min, 2012), los patrones de reconocimiento y las búsquedas inteligentes, lo cual permite entender 
el contexto de la información y los servicios con valor agregado que se deberán proporcionar a las comunidades.

De ahí que se comience a señalar que la innovación en los servicios de información dará un salto; de proveer servicios pasivos con una simple acumulación de conocimientos, a la creación de servicios que faciliten el desarrollo de conocimiento creativo y que se realicen a través de colectivos inteligentes. Entonces, los servicios modernos de información en las bibliotecas se estarán ideando para un mundo globalizado, gobernado por los teléfonos inteligentes, las tabletas y todo dispositivo móvil que requiere conexión a Internet, lo que provocará la creación y reconfiguración permanente de servicios de información. Esto es, la interoperabilidad semántica en un entorno de red global.

Actualmente, se habla y discute en torno a lo que persigue la era digital. Hay autores como Schmit y Cohen (2013: 30) que dicen que en la medida en que la conectividad digital llegue a los lugares más remotos del globo, los nuevos usuarios utilizarán mejor los objetos digitales y esto permitirá ampliar la gama de mercados, sistemas y comportamientos.

De igual forma, Rifkin (2002: 187) señala que en la nueva cultura del capitalismo, el acceso cobra importancia frente a la propiedad en la estructuración de la vida económica:

Las relaciones de propiedad son compatibles con un mundo en el que la primera tarea de la vida económica es la elaboración, fabricación y distribución de bienes físicos. Los objetos inanimados son fácilmente mensurables y, puesto que los bienes físicos pueden ser fácilmente cuantificados, se les puede asignar un precio... Pero en la nueva cultura económica, la estructura de la vida comercial ya no es simple. Estamos ante un mundo de símbolos, redes y bucles de retroalimentación, de conexiones e interacción, cuyas fronteras se oscurecen, donde todo lo sólido se desvanece en el aire. 
La era de la información invita a descubrir nuevos saberes y a comprender que hay una nueva cultura económica, que la estructura de la vida comercial ya no es tan simple, y que la reorganización de toda institución depende en gran medida de la tecnología.

El bibliotecólogo, frente a tal cambio, ha emprendido nuevos retos, los cuales lo han empujado a repensar su quehacer desde los fundamentos de la cultura de la innovación, la cual reconoce que los procesos y las prácticas actuales son mejores que las anteriores; y a apostar a que su rol profesional debe estar abierto a interpretar qué se entiende por economía global e innovación en los servicios, como una manera de reconfigurarse dentro de la revolución tecnológica.

Se advierte que en la era digital las innovaciones en los servicios de información estarán dando un salto de proveer servicios pasivos con una simple acumulación de conocimientos, a crear servicios que faciliten el desarrollo del conocimiento creativo y servicios a través de colectivos inteligentes.

LA GESTIÓN FORMAL E INFORMAL DE LA INFORMACIÓN

La formación y actualización de los ejecutivos es necesaria y más ahora que se están introduciendo diversos sistemas de gestión que requieren del uso de la tecnología. Varios son los motivos por los que los ejecutivos se renuevan en sus funciones, ya sea por una obligación específica, por la actualización en los procesos de trabajo y/o para la toma de decisiones.

Una de las conveniencias adoptadas en la mayoría de las empresas mexicanas ha sido la conferencia presencial, la cual cumple con el objetivo de difundir oralmente los conocimientos, que son compartidos por los expertos invitados 
quienes, a través de un modelo clásico de plática magistral, transmiten sus saberes y novedades. Este escenario dificulta la recopilación de información, pues algunos de los conferencistas se limitan a transmitir su comunicación de memoria, otros traen algunas notas manuscritas y los conferencistas más jóvenes traen una presentación visual.

Konzepte \& Conceptos (K\&C) es una empresa de servicios que se dedica a la organización de conferencias específicamente en los temas de actualidad en la administración. Su contacto con la gestión de la información gerencial inicia desde la petición y llega hasta la realización de una conferencia, la cual finaliza con la elaboración del reporte final denominando $\mathrm{K} \& \mathrm{C}$. El Reporte $\mathrm{K} \& \mathrm{C}$ es una pieza que está ligada de manera tangible al contenido de la conferencia. Es decir, la empresa abarca desde que el empresario hace su petición hasta la evaluación recabada por los asistentes del evento.

Ahora bien, ¿de qué forma han contribuido la bibliotecología y los estudios de la información a esta organización y gestión de la información en el Reporte K\&C? ¿Cómo se comprueba que el Reporte $\mathrm{K} \& \mathrm{C}$ capitaliza el retorno de inversión hecho por los empresarios en el sentido de ser generador de nuevos conocimientos para la organización? ¿El Reporte K\&C emplea alguna de las técnicas del análisis documental y crea algún sistema de información documental? K\&C desarrolló un sistema de información documental de conferencias formado por los siguientes elementos:

1. Identificación de la necesidad de información.

2. Preproducción. Identificación de la necesidad de formación/ capacitación.

3. Producción. Elaboración del programa.

4. Ejecución. Realización del evento. 
5. Postproducción. Análisis de resultados del evento.

6. Difusión. Entrega de resultados y comunicación de los mismos.

El valor agregado del sistema de información y el producto documental de este sistema es el reporte ejecutivo. Este documento contiene el registro de toda la información formal, informal y analítica emitida en cada conferencia.

I. Información formal. Es aquella información dictada durante la conferencia por el conferenciante; tanto la que se emite oralmente al exponer el tema, como la que hace referencia al material usado durante la exposición.

II. Información informal. Considerada aquélla que emiten los asistentes durante el evento y que suele convertirse en participaciones orales o escritas, expresiones, soluciones, análisis, sugerencias, acuerdos, etc. Pocos sistemas la registran, por lo que en la mayoría de estos eventos se ignora y se pierde una valiosa oportunidad de captarla y convertirla en un factor clave de creación de conocimiento.

III. Información analítica. Es aquella que puede medir factores predictivos de la satisfacción y el "valor" percibido por los asistentes con base en escalas numéricas, y que refiere específicamente a la contenida en las evaluaciones K\&C. Es decir, refiere a aspectos sobre la ejecución del evento y del desempeño del conferenciante.

Este reporte es entregado a las empresas clientes de K\&C. El reporte ejecutivo es una herramienta documental que provee de información clave para una mejor toma de decisiones en la formación de sus recursos humanos y que permite reflejar un mayor costo-beneficio de la inversión realizada en este tipo de eventos, al quedar registrada y ser susceptible de posteriores consultas y generadora de conocimiento. 


\section{Conclusiones}

Hemos de concluir este trabajo con el punto de vista bibliotecológico sobre la ventaja competitiva en la interacción entre los sistemas de información de gerencia y bibliotecarios, así como con la visión de un estudio práctico encuadrado en la obtención de información de la actividad de mayor significado para las empresas mexicanas: la realización de conferencias.

En el mudo empresarial, hablar de ventaja competitiva es sumamente común, no así en el ámbito bibliotecario. Para el empresario, existen factores que lo invitan a reflexionar si aún no ha comprendido la importancia de las tecnologías de la información en los sistemas gerenciales. Por ejemplo, la información sirve para tres objetivos organizacionales: la operatividad, el control y el contexto estratégico, además de los seis objetivos que mencionamos con antelación.

En el ámbito bibliotecario, Shumaker (2012: 28-29) refiere que el imperativo de la ventaja competitiva es mantenerse en la economía global. Esto es, los servicios bibliotecarios deben desarrollarse y mantenerse de acuerdo con las premisas de reducir sus costos con el propósito de ser competitivos. Además, deben considerar el valor agregado de sus servicios, así como desarrollar los perfiles apropiados para el bibliotecólogo disruptivo, como su alta especialización y capacidad de adaptarse a los constantes cambios que están experimentado los sistemas de información.

La nota final es que la posición que tome el bibliotecólogo disruptivo frente al reto de incorporarse al mundo empresarial será muy ambivalente. Por una parte, las empresas requieren de profesionales capaces y aptos para trabajar con las tecnologías de la información y los sistemas de información gerencial. Por otra, debido a su visión corta y permanencia en su trinchera histórica, puede ser que un 
bibliotecólogo no pueda adaptarse por querer conservar su integridad e independencia sin tomar parte en la toma de decisiones que le conciernen.

\section{Bibliografía}

Avendaño Garza, H. (2013). ¡A romper las reglas! Desde la idea hasta el negocio. Guía para emprendedores. México: Lena Verde Editores.

Glushko, Robert J. (ed.) (2013). The Discipline of Organizing. Massachusetts: The міт Press.

Gorman, M. (1995). "Five New Laws of Librarianship". American Libraries (septiembre).

King, N. y N. Anderson (2003). Cómo administrar la innovación y el cambio: guía para organizaciones. México: Thomson.

Kotter, J.P. y D.S. Cohen (2003). Las claves del cambio: casos reales de personas que han cambiado sus organizaciones. Barcelona: Deusto.

Kuhn, T. (2007). La estructura de las revoluciones científicas. Carlos Solís (trad.). México: FCE.

Laudon, K.C. y J.P. Laudon (2012). Sistemas de información gerencial. Alfonso Vidal Romero Elizondo (trad.). México: Pearson.

Min, Byung-Won (2012). "Next Generation Library Information Service-'Smart Library'". International Journal of Software Engineering and its Applications, 6 (4).

Rifkin, J. (2002). La era del acceso: la revolución de la nueva economía. Barcelona: Paidós.

Schmidt, E. y J. Cohen (2013). El futuro digital. Madrid: Social Business. 
Shumaker, D. (2013). The Embedded Librarian: Innovative Strategies for Taking Knowledge where it's Needed. Nueva Jersey: Information Today.

Todaro, J. (2014). Library Management for the Digital Age: A New Paradigm. Lanham: Rowman \& Littlefield.

Wilson, K. (2006). Computer in Libraries: An Introduction for Library Technicians. Nueva York: The Haworth Information Press. 


\title{
Uso de la información en la alta gerencia
}

\author{
Kenia Olivera González \\ Konzepte \& Conceptos (KEC)
}

\section{$\tau$}

a primera conferencia sobre administración la realizó el Servicio Postal Alemán en 1882, como afirma Peter Drucker (2002). En esa ocasión, la audiencia convocada estaba conformada por ejecutivos de la alta dirección y el tema fue cómo dejar de tenerle miedo al teléfono. Sin duda, el tema era adecuado para la época; sin embargo, nadie se presentó. Para los directivos fue ofensiva la invitación: ¿Cómo, si tenían subalternos, debían usar el teléfono? Con el paso del tiempo, la realidad se impuso.

Ciertamente, desde 1882 el mundo es diferente y del uso del teléfono la humanidad saltó al uso de las tecnologías de información (TI), pero hay cosas que permanecen; una de éstas es la resistencia al cambio. Con la explosión de la información y la masificación de las Ti, el paradigma del proceso informativo ha cambiado el lugar y modos de almacenamiento, búsqueda, recuperación y difusión de la información; estas modificaciones presentan un nuevo reto para los directivos, quienes deben desarrollar sus habilidades informativas para incursionar en la economía digital y ser partícipes activos en ella. 
Otro aspecto que se mantiene es la necesidad de información para el desempeño de tareas. El uso de la información es un tema que se ha estudiado desde mediados del siglo xx; sin embargo, el enfoque hacia el usuario de la información como el sujeto medular de la investigación y la determinación de sus necesidades informativas se dio hasta el último tercio de ese siglo. Podemos decir, de forma específica, que el estudio de los gerentes y directivos como usuarios de la información se realizó en la década de los setenta, cuando el objetivo de la investigación era determinar las necesidades y los usos que este tipo de usuario daba a la información. El que se hicieran esta clase de análisis en esa década no fue casualidad, sino resultado del advenimiento de la sociedad de la información, de la cual se tiene registro en la década de los sesenta.

Ahora bien, los gerentes y directivos desarrollan sus responsabilidades profesionales dentro de un ecosistema llamado empresa que, tomando la definición acuñada por uno de los empresarios más exitosos de nuestro país, Lorenzo Servitje, se entiende como un instrumento de servicio capaz de llegar a una sociedad donde la economía está al servicio del hombre y no al revés. Para Lorenzo Servitje, la empresa, independientemente de que requiera cumplir con cierta rentabilidad, debe ser total y plenamente humana. En ella, sus miembros están comunicados, organizados, coordinados y estructurados para realizar una actividad determinada que les es de interés común. En este microambiente, se tienen normas, reglamentos, valores perfectamente definidos, metas y objetivos conocidos por cada integrante, los cuales sirven de guía para que cada elemento del ecosistema cumpla con sus tareas de la mejor manera.

La empresa está estructurada por áreas, y cada área tiene sus propias metas y objetivos que, a través de su cumplimiento, apoyan el logro de objetivos generales de la organización. 
Además, cada área tiene sus departamentos, sus procesos y operaciones, y a través de ellos éstas se interrelacionan. Lo anterior se puede equiparar a la manera en que cada órgano y miembro del cuerpo humano se relaciona uno con otro para mantener al cuerpo en su totalidad dentro de un sano equilibrio.

En el interior de la organización, existe una relación directa entre las necesidades de información y la especificidad de las funciones desempeñadas por sus miembros. Mientras más exacta es la función de un departamento, la información que requiera la persona que en él se desempeña también será más acotada. Pero para aquellas áreas en donde los ejecutivos no tienen tareas como la supervisión, sino que sus funciones son de estrategia, las responsabilidades los obligarán a necesitar información que ya no es tan específica, y por lo tanto, tampoco tiene una ubicación y recuperación inmediata. Las necesidades informativas de la alta dirección, señaló desde 1978 John Rockart, no están determinadas con tanta claridad en la alta gerencia debido a las responsabilidades mismas del puesto, y no se debe perder de vista que la responsabilidad más demandante para los directivos es la toma de decisiones.

Con la Sociedad de la Información y la Sociedad del Conocimiento, se plantean las llamadas "metas del milenio", a las cuales las empresas no son ajenas; por este motivo, se han determinado un conjunto de habilidades que el directivo del tercer milenio necesita cumplir, y la primera de éstas es tomar decisiones sustentadas en información valiosa. Al hablar de información, se está haciendo referencia a toda la información existente, no únicamente aquella que posee o genera la empresa. Esto supone un gran reto porque con la explosión de la información, el ejecutivo no sólo se enfrenta a una mayor cantidad, sino también a la velocidad inimaginable de su generación y disposición gracias a Internet. 
Además de la velocidad con la que se genera y se hace disponible, la información ahora proviene de múltiples plataformas tanto móviles como estacionarias.

El dictamen de las metas del milenio para las empresas es claro: poseer información valiosa, no más decisiones basadas en la experiencia del directivo y de la empresa, no más intuición. Ahora se pide que se recupere toda la información generada hasta la fecha en un determinado tema para que sea puesta a la disposición del ejecutivo y éste pueda analizarla y tomar una decisión fundamentando por qué la tomó. En el microambiente de las empresas, esto se hace más complejo que en cualquier otro; en las organizaciones, las decisiones y su ejecución deben hacerse a la brevedad porque la competencia y el mercado no esperan.

En 1977 se publicó la entrevista que J.F. Rockart hizo a Anthony J.F. O'Reilly, entonces presidente de H.J. Heinz, y a William Dougherty, entonces presidente del banco de Carolina del Norte. En la entrevista, O'Reilly declaró que, en cuanto al tema de la información, lo que directamente golpea al directivo es la cantidad de información que se obtiene iporque es mucha!, y esto les genera encrucijadas porque deben lidiar con una gran cantidad de datos, muchos de los cuales son irrelevantes. Además, el director no tiene tiempo para analizar ese monto de información. Por su parte, William Dougherty apuntó que el problema es que la alta gerencia se enfrenta a enormes paquetes de reportes en los que debe determinar la información crítica para la toma de decisiones, y -nuevamente- no cuenta con el tiempo suficiente para ello.

La problemática comienza a plantearse, el ejecutivo debe contar con la información que le permita tomar decisiones fundamentadas en el menor tiempo posible. Para maximizar el uso del tiempo, lo ideal sería que él mismo pudiera seleccionar la información de valor al momento en que la va 
recuperando. Para ello, debe aprender a utilizar las plataformas de información y sus tecnologías con el fin de recuperar la mayor cantidad de datos útiles. El problema expresado en una pregunta es, ¿cómo lograr que el ejecutivo de la alta dirección solucione el proceso de búsqueda, recuperación y utilización de la información para que pueda tomar decisiones sustentadas en ella? Como profesionales de la información, sabemos que la respuesta es: desarrollando sus habilidades informativas (DHI); sin embargo, dado el perfil de este usuario y su contexto, el modelo bajo el cual se diseñe el programa para el DHI debe ser muy especial y cumplir con ciertas características.

El ejecutivo necesita información de valor especialmente para tomar decisiones. El proceso de toma de decisiones, que no se explicará en este trabajo, está enmarcado en una necesidad informativa. Esto significa que toda la actividad intelectual que se produce para decidir qué hacer se desarrolla dentro de la comprensión de esa necesidad de información, la cual es el parámetro para determinar qué se busca, dónde buscarlo, qué se adquiere y qué se desecha. Para realizar este procedimiento racional, también se necesita hacer uso de la información y experiencia adquiridas en el pasado y que, gracias a su implementación y análisis, se han convertido en un conocimiento tanto para el ejecutivo como para la organización en general (conocimiento explícito). Existe, pues, una amalgama de la nueva información recuperada con la información y experiencia acumulada. Este proceso, apoyo para la generación del conocimiento, obliga a que el programa de DHI se enmarque en un modelo que permita:

1. Comprender la situación real en la que se requiere tomar una decisión y saber qué información se requiere para poder fundamentar dichas decisiones. 
2. Con base en la comprensión de la situación, ser capaz de buscar, ubicar y recuperar la información.

3. Valuar la información recuperada para determinar cuál es útil o no.

4. Aplicar la información adquirida para tomar decisiones.

5. Ser capaz de medir la efectividad de todo el procedimiento para introducirlo a un proceso de mejora continua.

Para buscar una solución a esto, se incursionó en una revisión bibliográfica que diera respuesta a las necesidades específicas detectadas en estos usuarios, porque con base en los puntos arriba enumerados es entendible que este tipo de usuario requiere de otras habilidades además de las informativas. Si la toma de decisiones estratégicas basadas en información y no sólo en intuición y experiencia supone ser capaz de conjugar la situación en la que se encuentra la empresa, sus valores, sus políticas, su operación, sus finanzas, su posición en el mercado, su posición ante la competencia y la meta de satisfacer a sus clientes y accionistas, con todo el bagaje de experiencia y conocimiento adquirido en el pasado, entonces el ejecutivo requiere desarrollar su pensamiento crítico. Por otra parte, al desempeñarse dentro de una organización, se ve obligado a medir cada proceso que ejecute para conocer su efectividad e introducirlo al mundo de la mejora continua para hacer de él una ventaja competitiva. Para lograr este último aspecto, el ejecutivo debe desarrollar su capacidad de aprendizaje para toda la vida.

La revisión de la literatura nos llevó a la medicina basada en la evidencia (MBE), que es definida por David Sackett como el uso consciente, explícito y juicioso de la mejor evidencia actual en la toma de decisiones sobre el cuidado de los pacientes individuales. De la MBE se desprende el modelo de obtención de información basada en la evidencia (MOIBE), en 
el cual cada variable clínica es tomada en cuenta: las preferencias del paciente y sus acciones son lo más importante, después se toman en cuenta su estado clínico y sus circunstancias, y en último lugar se considera la evidencia de la investigación. Las primeras variables se evalúan, se integran a la experiencia del médico y se usan para decir qué se puede hacer; pero es la información valiosa en conjunto con el todo generado lo que deja ver al médico lo que debería hacerse.

El MoIBE tiene cinco etapas:

1. Preguntar. Reconocer la información que se necesita y expresarla en una pregunta.

2. Adquirir. Encontrar toda la información que se ha generado sobre el tema en cuestión para hacerse de la mejor evidencia.

3. Valorar. Seleccionar la mejor evidencia.

4. Aplicar. Hacer uso de la información.

5. Evaluar. Analizar cómo se desarrolló todo el proceso para mejorarlo.

El programa de DHI propuesto para la alta gerencia tiene cinco módulos correspondientes a cada una de las etapas del MoIBE. El primer módulo trata sobre entender la necesidad de información en su complejidad total, al grado de poder expresarla en una pregunta que pueda ser contestada con la información que se recupere.

El segundo módulo abarca el tema del diseño de una estrategia de búsqueda. Aquí el ejecutivo determinará cuáles son los elementos que conforman su necesidad informativa y cómo nombrarlos - la idea del lenguaje controlado, los motores de búsqueda, las bases de datos, las fuentes de información, etcétera. Todo ello se conjuga en este módulo, que es tratado bajo la óptica del ejecutivo. 
En el tercer módulo, se inicia con la valoración de la información recuperada. Aquí se le enseña al ejecutivo a evaluar la calidad de las diferentes fuentes tanto de texto como electrónicas. Las ideas del meta-análisis y del ordenamiento de la información se hacen presentes en este módulo. En él, el ejecutivo también aprenderá a realizar una síntesis de información.

El cuarto módulo es la aplicación de la información ya valorada y calificada. El ejecutivo se basará en su síntesis de información para proyectar escenarios y resultados posibles al aplicarla. Esto es una tarea estratégica en su totalidad.

Finalmente, en el quinto módulo se evaluará todo el proceso. El ejecutivo hará un diagrama de éste y puntualizará las fuerzas y debilidades del mismo, así como sus oportunidades y amenazas. No se trata de que haga un análisis de su desempeño; el enfoque a seguir es determinar las áreas de oportunidad que tiene el proceso para que éstas sean mejoradas y se pueda obtener una mayor ventaja de él hasta convertirlo en una ventaja competitiva.

La respuesta que se entrega a esta comunidad de usuarios es un programa personalizado en el que la tarea fundamental de formación de usuarios se pone al servicio del sector productivo. La problemática de éstos no podría ser solucionada por un agente diferente al profesional de la información porque es él quien tiene el conocimiento de las nuevas formas de ordenar la información, de búsqueda y de recuperación. Sólo él puede capacitar a estos usuarios y trabajar con ellos de forma multidisciplinaria.

El programa ya ha sido llevado a las puertas de una de las empresas nacionales líderes en la industria alimenticia a nivel global. Sus resultados son motivo de otra publicación. 


\section{Bibliografía}

Adams, N.E. (2014). A Comparison of Evidence-Based Practice and the ACRL Information Literacy Standards: Implications for Information Literacy Practice. Disponible el 16 de julio de 2017 en: https://pdfs.semanticscholar.org/6802/b81afb28cf40e07a91 882ad14ea2ace95415.pdf.

Delgado-Noguera, M. (2015). "David Sackett y la medicina basada en la evidencia”. Revista Ciencias de la Salud, 17 (3), 8-9.

Drucker, P.F. (2002). La generación en la sociedad futura. México: Norma.

Hernández, P.E.S. (2015). “Transformación de la metodología para estudiar a los usuarios de la información”. En Jaime Ríos Ortega y César Augusto Ramírez Velázquez (coords.). Naturaleza y método de la investigación bibliotecológica (209-252). México: IIBI.

Pfeffer, J. y R.I. Sutton (2006). "Evidence-Based Management”. Harvard Business Review, 1 (13). Disponible en: https://hec.unil. ch/docs/files/56/1290/pfeffer_\%26_sutton_2006_evidence_based_management_hbr.pdf.

Satterlee, B. (1999). The Acquisition of Key Executive Skills and Attitudes Required for International Business in the Third Millenium: Documento ERIC.

The Center for Evidence-Based Management (s/f). Disponible el 18 de agosto de 2015 en: http://www.cebma.org/.

The Centre for Evidence-Based Medicine. Critical Appraisal (s/f). Disponible el 17 de febrero de 2016 en: www.cebm.net/index. aspx?o=1157. 


\title{
El profesional de la información \\ y sus servicios en el análisis de la información formal, informal y analítica en las conferencias de negocios
}

\author{
María de Lourdes Nieto Ponce \\ Konzept \& Conceptos (K\&C)
}

\section{INTRODUCCIÓN}

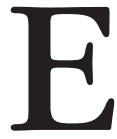

n este caso de estudio, se aborda la aplicación de un sistema de información documental para conferencias que ha sido probado por más de veinte años en el área de formación de recursos humanos, y el impacto que ha tenido en un grupo financiero mexicano.

\section{LA CONFERENCIA DE NEGOCIOS}

Las empresas del sector productivo requieren desarrollar sus recursos humanos como una acción clave para enfrentar la competencia y para asegurar que su operación, objetivos y estrategias sean viables y sostenibles. La formación de los recursos humanos puede llegar a ser un activo de conocimiento si la información que se produce en estos esfuerzos se visualiza como un factor susceptible de registrarse, representarse y recuperarse. 
La necesidad de información en la formación de ejecutivos deriva de diversos requerimientos: obtener una instrucción especializada; encontrar soluciones para una problemática operativa; enfrentar un nuevo reto en un área específica de la organización; o simplemente actualizar y/o especializar a un grupo de ejecutivos. Las respuestas para estas demandas usualmente son resueltas con la inversión en diferentes eventos como conferencias, seminarios, cursos, benchmarking, etcétera.

Para efectos de esta presentación, se tratará solamente el caso de la conferencia interna o in-house. En este tipo de conferencia, el "objetivo es que el asistente encuentre la información específica que requiere para actualizar, resolver, homologar y/o tomar decisiones aplicables en un área de la empresa. Para su realización, las empresas invierten considerables recursos económicos que reflejan un beneficio tangible cuando los conocimientos son puestos en práctica" (Nieto, 2016: 42). Su característica principal es que se produce $e x$ profeso para una organización, usualmente por proveedores externos a ella. En este caso, es la empresa Konzepte \& Conceptos (K\&C) la firma productora de la conferencia que ha sido realizada para la empresa financiera en cuestión.

Las empresas producen y usan importantes volúmenes de información, los cuales requieren generar conocimiento específico para mejorar la realización de actividades y procesos del negocio. Una herramienta para lograrlo es la memoria de la organización — recogida por la gestión del conocimientoque puede ser ubicada en los repositorios institucionales. Ésta debe ser reconocida como un activo intangible, es decir, que se considere su valor potencial de generación de conocimiento para la organización. Una de las vías que las empresas pueden aprovechar como una fuente para la gestión del conocimiento, como materia prima del repositorio, son las conferencias. 
El planteamiento que hace la disciplina bibliotecológica al visualizar las conferencias como un recurso de información ofrece a la empresa la posibilidad de maximizar su costo-beneficio en la inversión de estos eventos. La conferencia como evento de formación, debería ser reconocida como un recurso de información, es decir,

una conferencia que se dicta en formato presencial, que por tanto es primero una fuente de información oral que posteriormente es registrada en un documento en formato textual y que requiere un análisis documental para convertirse en un recurso de información que asegure que podrá ser recuperado y potencializarse como generador de conocimiento (Nieto: 9).

Con la aplicación de un sistema que permita registrar, representar y recuperar la información pueden ser maximizados los beneficios de los esfuerzos de aprendizaje y formación que se realizan en la organización, incluidas las conferencias. Las conferencias llevadas a un sistema de información documental además pueden convertirse en la entrada al proceso de gestión de conocimiento.

Usualmente, las conferencias que se dictan en las empresas han sido vistas desde un sólo enfoque, el comunicacional. En este enfoque, las conferencias se perciben simplemente como un acto de comunicación entre un remisor y un receptor, lo que implica una comunicación unidireccional que limita la visualización de éstos como eventos en donde sólo existe transmisión de información $y$, por tanto, a su término finaliza el ejercicio informativo.

Bajo el enfoque de la disciplina bibliotecológica, se concibe las conferencias bajo el concepto de un sistema de información, es entonces que el evento toma el sentido de un recurso 
generador de conocimiento. Si la información que genera una conferencia se registra y queda plasmada en un documento para el caso que describimos, el documento es el Reporte Ejecutivo $\mathrm{K} \& \mathrm{C}$ - , se podrá dar un tratamiento documental para identificar su contenido y posteriormente será susceptible de ser recuperado. "[...] entonces y sólo entonces, podremos decir que esta fuente de información oral se ha convertido en un recurso de información al ser la representación tangible que permitirá que la información pueda ser susceptible de recuperarse y potencialmente pueda crear conocimiento" (Nieto, 2016: 26).

Robert Taylor señala que los sistemas de información son una serie de procesos formales por los que la utilidad potencial de un mensaje específico se ve reforzada al ser procesado, es decir, se le agrega valor. "Energía, tiempo y dinero deben ser invertidos para cambiar datos inútiles en conocimiento productivo a través de un proceso de valor agregado" (Taylor, 1982: 341).

Por su parte, el Diccionario de Ciencias de la Documentación define el Sistema de Información Documental como un conjunto de personas, máquinas y procedimientos que transforman una información documental de entrada (input) en una de salida (output) preparada para que un determinado usuario obtenga una nueva información y tome una decisión eficaz (Nieto, 2016: 53).

El Sistema de Información Documental de Conferencias K\&C se ha desarrollado como respuesta de la disciplina bibliotecológica para contribuir en la maximización del costo-beneficio de la inversión que el área de formación de la organización realiza en conferencias.

El Sistema de Información Documental de Conferencias K\&C está conformado por los siguientes elementos:

1. Identificación de la necesidad de información. 
2. Pre producción.

3. Producción.

4. Ejecución.

5. Postproducción.

6. Difusión.

\section{Sistema De Información Documental de Conferencia} K\&C

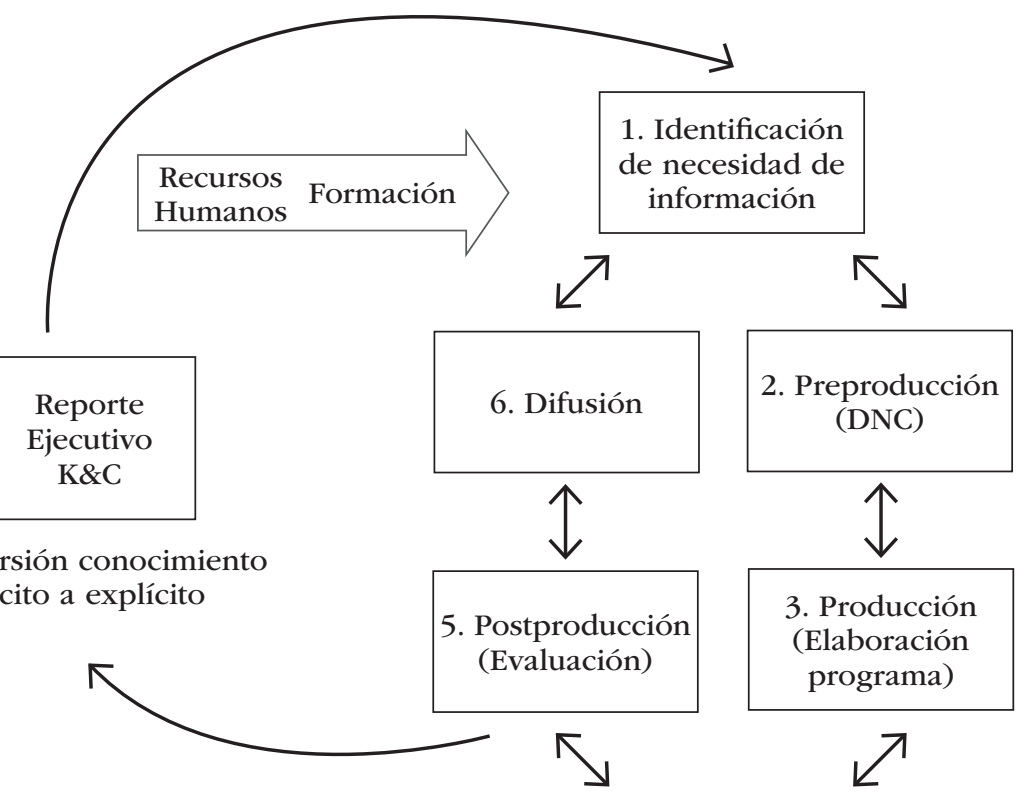

Conversión conocimiento tácito a explícito

3. Producción (Elaboración programa)

4. Ejecución (Realización)

El sistema de información documental de conferencias K\&C.

Fuente: Nieto P. (2016: 59). 
El Sistema de Información Documental K\&C inicia con la Identificación de la necesidad de información. Durante esta fase, se realiza el contacto con el cliente, quien demanda el servicio de información en una conferencia. En esta fase, se deberá entender cuál es la información que requiere el cliente e identificar claramente dos elementos fundamentales: el tema a desarrollar y los alcances del mismo, es decir, qué quiere lograr el cliente con ello.

Con la información recabada durante la entrevista y plasmada en el Pliego de peticiones, se inicia la fase de Preproducción. Como su nombre lo dice, esta fase es previa a la producción del evento y, por tanto, de no ser aprobada por el cliente, el proceso se cierra en este paso. Si el cliente aprueba, K\&C convierte la información proveída por el cliente en una respuesta en forma de programa de conferencia, el cual es plasmado en el documento Propuesta técnica, cuyo fin es satisfacer la necesidad de capacitación y/o formación en objetivos generales y contenidos. En esta propuesta, se incluye la investigación y el desarrollo de temas y subtemas asegurando que el contenido sea conforme a lo que espera el cliente con equilibrio en la entrega de la información, evitando la redundancia y ajustándolo al horario aprobado, entre otros requerimientos.

La Producción inicia cuando se aprueba la Propuesta técnica y durante esta fase se consideran todas las acciones que implican convertir el programa aprobado en un programa de conferencia que sea realizable.

La siguiente fase, Ejecución, es el momento en el que se lleva a cabo el evento: es la conferencia. Aquí se realiza el dictado de la conferencia, la sesión de preguntas y respuestas y la aplicación de Evaluaciones. La mayoría de los procesos de conferencias consideran su término en este momento. En el sistema de información documental de K\&C, el evento no finaliza aquí, se añade una fase más que es el factor determinante 
para generar valor: el monitoreo durante toda la ejecución de la conferencia. Esta información contiene los detalles de todo lo acontecido durante el evento, tanto la información formal que el conferenciante ha entregado, como la informal que han vertido los asistentes a lo largo de la sesión. Con ellas se constituirán los elementos del Reporte Ejecutivo K\&C.

El valor agregado de la conferencia se realiza en la postproducción. En ella se lleva a cabo el análisis de resultados del evento, en el que se contiene el trabajo de documentación más significativo; se compendia toda la información vertida durante la conferencia y se documenta en el Reporte Ejecutivo. El denominado Reporte Ejecutivo $\mathrm{K} \& \mathrm{C}$ permite resguardar los contenidos de los diversos temas que de manera oral y/o escrita son compartidos por los conferencistas, la información que generan los asistentes de las empresas solicitantes y los resultados de la evaluación que contiene la percepción que los asistentes se han formado de la conferencia. Por medio de este reporte, los ejecutivos de una organización pueden obtener la información completa que ha sido compartida durante el evento por el especialista del tema y, más aún, la generada entre los grupos de trabajo (acuerdos, recomendaciones, propuestas, quejas, soluciones, etcétera.), lo que puede proporcionar a la organización conocimiento tácito y un pulso sobre el clima organizacional.

BENEFICIOS REPORTADOS SOBRE LA APLICACIÓN DEL Sistema de Información Documental K\&C PARA UNA EMPRESA DE SERVICIOS FINANCIEROS

El Sistema de Información Documental de Conferencia K\&C se aplicó en una conferencia para una empresa de servicios financieros. Esta empresa de negocio de pagos y cambios de 
divisas desde 1985 es líder en el mercado nacional, cotiza en la Bolsa Mexicana de Valores y tiene un alcance de servicios nacional e internacional. La necesidad de esta institución financiera era que los ejecutivos de la zona metropolitana reforzaran sus habilidades de comunicación personal y aprendieran a relacionarse en forma efectiva con sus colaboradores. La propuesta de la firma Konzepte \& Conceptos $(K \& C)$ fue la realización de una conferencia titulada "Eneagrama, la identidad de tu zona humana" para que cada ejecutivo identificara sus habilidades psicobiológicas y aprendiera a establecer una mejor comunicación con sus alternos, subalternos y directivos. La conferencia se ejecutó de acuerdo con lo propuesto y se aplicó el Sistema de Información Documental. Se entregó al cliente el documento Reporte Ejecutivo K\&C.

Este reporte contenía tres bloques:

- Información formal. La descripción de cómo se llevó a cabo el evento.

- Información informal. Todas las expresiones de los asistentes durante el evento: los acuerdos a los que llegaron, su definición de objetivos para el próximo año, así como sugerencias para siguientes acciones en cuanto a seguimiento de capacitación y desarrollo. - Información analítica. Los resultados de la evaluación del evento y del speaker que han hecho los asistentes de acuerdo con sus expectativas y objetivos a cumplir.

La entrega de este documento se hizo al ejecutivo que solicitó la realización de la conferencia, quien lo revisó y reportó sus beneficios en este V Coloquio de Investigación Bibliotecológica y de la Información: Colaboración entre la bibliotecología y los sectores productivos y económicos. El ejecutivo expuso durante su participación que el Reporte Ejecutivo K\&C le permitió identificar que: 
- De todos sus proveedores de conferencias, la firma K\&C es la única que entrega este reporte con información clave de la conferencia. - Con este reporte, se puede tener conocimiento de cómo fue el evento aun sin estar presente.

- Con este reporte, se puede tener información específica de lo que han comentado los asistentes: acuerdos, sugerencias, propuestas, inclusive quejas, lo que convierte al evento en información de ida y vuelta, no sólo de ida como una conferencia tradicional que no se registra.

- El Reporte Ejecutivo es un apoyo para la toma de decisiones en la formación de los recursos humanos y para futuros eventos de formación.

- El costo-beneficio de este reporte se maximiza, ya que al mismo tiempo que se cumplen los objetivos de formación de los recursos humanos, también se cuenta con un documento que expande la información al identificar los aportes de la audiencia, además de que, al tener registrado el evento, es susceptible de ser conservado y, por tanto, consultado para posteriores eventos a desarrollar.

Con base en este testimonio, se constató que el Reporte Ejecutivo K\&C puede generar para la empresa-cliente beneficios de valor agregado, mejoría en la toma de decisiones, maximización de tiempo para los ejecutivos, mejoría del costo-beneficio y la posibilidad de ser un elemento clave para la generación de conocimiento, pues contiene la información informal que bajo la concepción teórica de Nonaka y Takeuchi (1995) se considera conocimiento tácito, el cual puede llegar a convertirse en conocimiento explícito $y$, por tanto, en un valor altamente apreciable para la empresa que realiza esfuerzos de gestión de conocimiento.

Para la disciplina bibliotecológica, este caso permite inducir que si la información que genera la conferencia se registra en un documento y este documento es sometido a técnicas 
de análisis documental, entonces y sólo entonces podremos decir que esta fuente de información oral se ha convertido en un recurso de información al haber sido transformada en una representación tangible que permitirá que la información pueda ser susceptible de recuperarse, y que potencialmente pueda crear conocimiento en la empresa.

Este caso también lleva a identificar que existe una oportunidad para la disciplina bibliotecológica en el estudio y la entrega de servicios para las empresas y la resolución de sus necesidades de información. La empresa puede ser vista como otro campo de actividad para los profesionales de la información, su participación implica un elemento clave para añadir valor a la información que ésta genera. La diferencia entre contar con especialistas de la información o no puede dar a la organización la ventaja competitiva que éstai requiere no sólo en el área de formación ejecutiva, sino en todas aquéllas susceptibles de generar información. 


\section{Bibliografía}

Nieto, P. (2016). Conferencias de negocios: Análisis de la información formal, informal y analítica. México: unam. Disponible el 25 de noviembre de 2016 en: http://132.248.9.195/ptd2016/ octubre/080378475/Index.html.

Taylor, A.G. y D.N. Joudrey (2004). "The Organization of Information". Organization in Human Endeavours, 1, 1-14. Disponible en octubre del 2016 en: http://ils.unc.edu/courses/2013_ spring/inls200_002/Readings/Taylor1999.pdf.

Taylor, R.S. (1982). "Value Added Processes in the Information Life Cycle". Journal of the American Society for Information Science, 33 (5), 341-346. Disponible en octubre del 2015 en: https:// www.asis.org/Publications/JASIS/Best_Jasist/1982Taylor.pdf.

Yepes, J.L. (2005). "Diccionario enciclopédico de Ciencias de la Documentación”. En Documentación de las Ciencias de la Información. Madrid: Síntesis. 
Investigaciones posdoctorales en el IIBI 


\title{
Usabilidad del software como indicador de la Information Literacy: una propuesta para la comprensión de la inteligencia en la Era de la Información
}

\author{
Marco Brandẽo \\ Programa de Becas Posdoctorales en la UNAM \\ Becario del Instituto de Investigaciones \\ Bibliotecológicas y de la Información
}

INTRODUCCIÓN

n tiempos en los que la información está en evidencia,
al justificar las concepciones de sociedad o Era de la
Información muchos análisis tienen lugar para definir
el alcance de estos cambios en todas las áreas y niveles. Es
cierto que la información siempre ha estado presente en la
humanidad como un factor clave para las relaciones del hom-
bre con la naturaleza y con la sociedad en todos sus aspectos.
Es por ésa y otras razones que pensadores como Kumar
(1997) la considera un elemento omnisciente y omnipresen-
te en la humanidad cuyas características no están sólo en las
abstracciones alfanuméricas.
Sin embargo, es a través de estas abstracciones alfanumé-
ricas que la información aumenta su potencialidad cada vez
más y seguramente por ser hoy multifacética en una amplia 
variedad de formatos, proporcionada principalmente por las tecnologías digitales, se destaca como un factor de cambio en todas las áreas. Una de éstas es la que concierne a habilidades humanas identificadas como "la inteligencia", un tema tradicionalmente complejo y que consiste en la percepción y confrontación de otras tantas áreas del conocimiento. Una definición reciente del Mainstream Science on Intelligence en 1994 describe la inteligencia como:

Una capacidad mental muy general que, entre otras cosas, implica la habilidad de razonar, planear, resolver problemas, pensar de manera abstracta, comprender ideas complejas, aprender rápidamente y aprender de la experiencia. No es un mero aprendizaje de los libros, ni una habilidad estrictamente académica, ni un talento para superar pruebas. Más bien, el concepto se refiere a la capacidad de comprender el propio entorno.

Lo expresado en esa concepción parece interesante para la superación del concepto de inteligencia como algo más que un aprendizaje de libros y un talento para superar exámenes, este tipo de significado está relacionado con la idea de que la gente inteligente es culta o son los mejores estudiantes de la escuela.

Por otra parte, en una época en la cual el acceso a la información es más abierto y democrático a través de las tecnologías, y la información está en la base de cualquier conocimiento o habilidad (Morales, 2013: 120), una percepción de la inteligencia humana debe considerar habilidades de gestión de la información.

Aquí se presenta el resultado de una investigación que apunta a la expansión del concepto de inteligencia a términos de una realidad en la cual las tecnologías digitales representan significativamente los medios con los que se obtienen resultados de inteligencia y productividad. 
LA INVESTIGACIÓN: EL ORIGEN, LA METODOLOGÍA COMO PROCESO Y LA METODOLOGÍA COMO PRODUCTO

\section{Origen}

Esta investigación se originó en el año 2007 a partir de la observación de un fenómeno en una universidad brasileña: al implementar una política de software libre, se notó que los funcionarios y los estudiantes eran resistentes al cambio de software operativo y a las nuevas aplicaciones, y que su productividad se vio significativamente afectada.

Algunos estudiantes empezaron a usar los nuevos softwares en el desarrollo sus trabajos con las diferentes herramientas informáticas, y estuvieron más orientados a la ejecución de la actividad que al software con el cual la harían. En esa primera observación, fue constatado que estos estudiantes eran más independientes, demandaban menos ayuda; cuando se les preguntó sobre lo que hacían en el laboratorio de cómputo, contestaron con el nombre de la tarea, no con el nombre del software; eran los más detenidos en el trabajo, menos dispersos, y tenían un rendimiento superior en las disciplinas de su curso.

Estas percepciones crearon las preguntas básicas de la investigación que hasta hoy conforman su gran problemática: ¿la capacidad de un individuo de usar diferentes softwares puede servir como un indicador de productividad? ¿La cantidad de softwares utilizados puede ser un parámetro para evaluar la capacidad de conocimiento? ¿El uso de software puede considerarse como un elemento para la evaluación del desempeño?

Un esfuerzo de comprensión empezó a tomar forma para responder a estas cuestiones, especialmente en sistemas de activos intangibles, como es considerada la educación o una 
empresa de conocimiento. El primer reto fue una construcción metodológica que resultó ser no sólo el procedimiento de la investigación, sino también parte de su resultado.

\section{La metodología como proceso}

En la construcción de la metodología como proceso, el primer paso fue considerar que las computadoras han constituido una parte significativa del trabajo de hoy y, en el caso de la organización estudiada, se evidenció en sus procesos funcionales; en segundo lugar, se comprendió la dependencia técnica que implica esta tecnología en las organizaciones, es decir, el sentido de su uso como un medio para cumplir una tarea; y en tercer lugar, se intentó identificar el componente del trabajo del que se encarga esta herramienta hasta llegar a la unidad básica de todas las situaciones humanas: la información.

De esta manera, se considera que las computadoras, a través de sus softwares, son manipuladores de información: sirven para hacer peticiones (entradas) y devolver las respuestas (salidas) necesarias para trabajar. Por ejemplo, un robot recibe información (caminar, pintar, buscar etcétera.) vía software. Esta información regresa como una respuesta a la tarea solicitada (llevar algo, pintar una superficie, obtener información en un sitio, etécetera).

La información no está en un software, puede ser manipulada por diferentes aplicaciones, es decir, la misma tarea puede ser realizada por diferentes softwares. Por lo tanto, sería necesario evaluar la usabilidad de software de una persona para presentar la probabilidad que tiene de utilizar eficientemente la información. Esta hipótesis condujo al concepto de Information Literacy como la forma de evaluar la capacidad de información de una persona. 


\section{La metodología como producto}

De la asociación entre la usabilidad del software y el concepto de Information Literacy, se creó una metodología de evaluación que genera un índice probabilístico de una persona para utilizar eficientemente la información. Este índice, identificado en la función siguiente, fue llamado "Índice de Information Literacy" $\left(C_{i)}\right.$

donde

$$
C_{i}=x(1,2,3,4,5,6,7,8,9,)
$$

$$
x=\text { puntos de la Information Literacy }{ }^{1}
$$

$$
x \neq 0
$$

Esa metodología fue aplicada a más de cuatro mil empleados que han sido estudiantes de la universidad y se analizaron 17.4 por ciento de la muestra (la perspectiva era 10 por ciento), cuyos $C_{i}$ se compararon con los índices de rendimiento escolar y de productividad laboral, de lo cual resultó una interesante coherencia (véase gráficos de págs. 366 y 367). ${ }^{11}$

Estos resultados permitieron las consideraciones que condujeron el estudio a otro nivel, incluyendo a esta investigación postdoctoral, que pretendía aclarar y consolidar los factores que identifican y escalan la Information Literacy al mostrar los aspectos que contemplan y complementan una nueva comprensión de inteligencia que tiene la información como el paradigma.

11 Clasificación de áreas de conocimiento según CAPES (Brasil, 2013): DUR: Ciencias Duras (matemáticas, física, química, etc.); ING: Ingenierías; HUM: Humanidades (sociología, psicología, historia, etc.); BIO: Ciencias biológicas (medicina, biología, zoología, etc.); ARTE: Artes y literatura (teatro, artes plásticas, literatura, etc.); APL: Ciencias sociales aplicadas (derecho, administración de empresas, etc.). Fuente: Brandao, 2013: 94-96. 


\section{Rendimiento escolar}

7

6

5

4

3

2

1

0

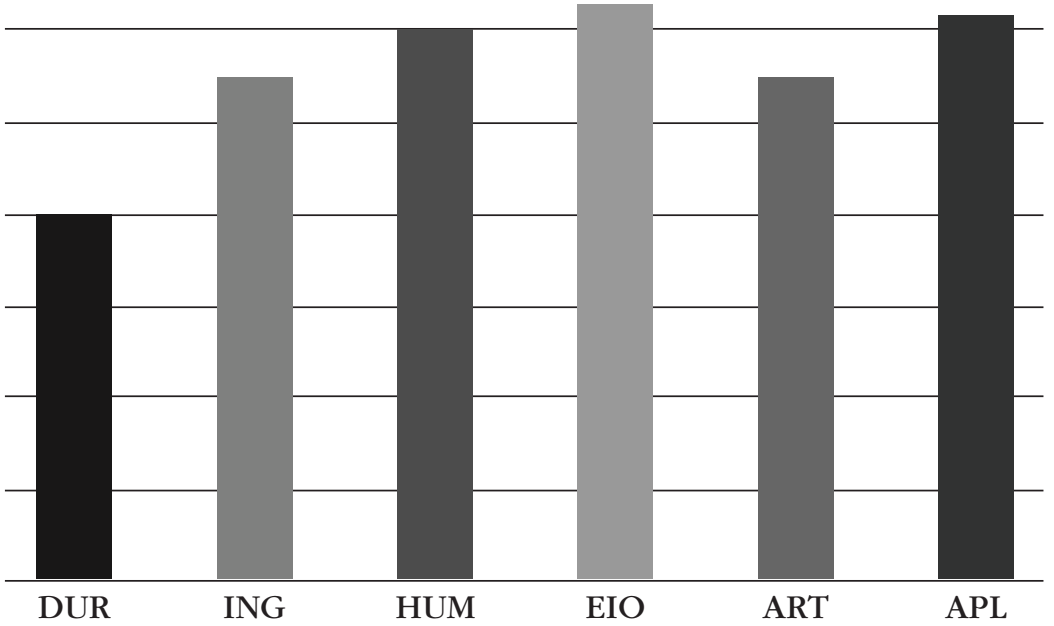

Gráfico 1. Evaluación del rendimiento escolar por área de conocimiento.

\section{Productividad}

7

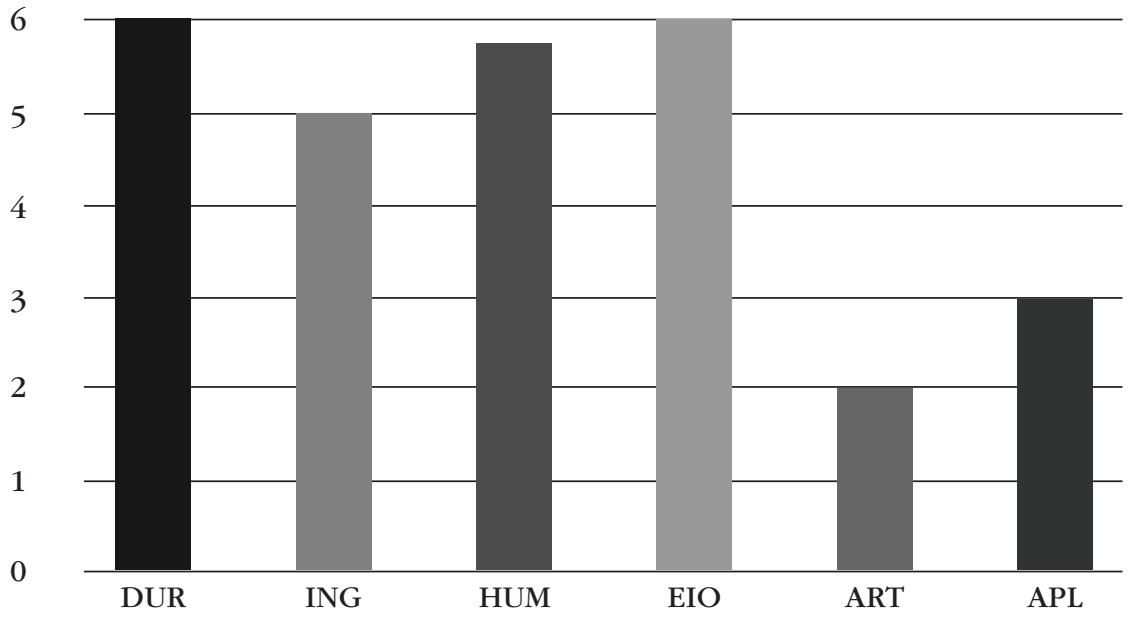

Gráfico 2. Evaluación de productividad por área de conocimiento. 
8

$C_{i}$

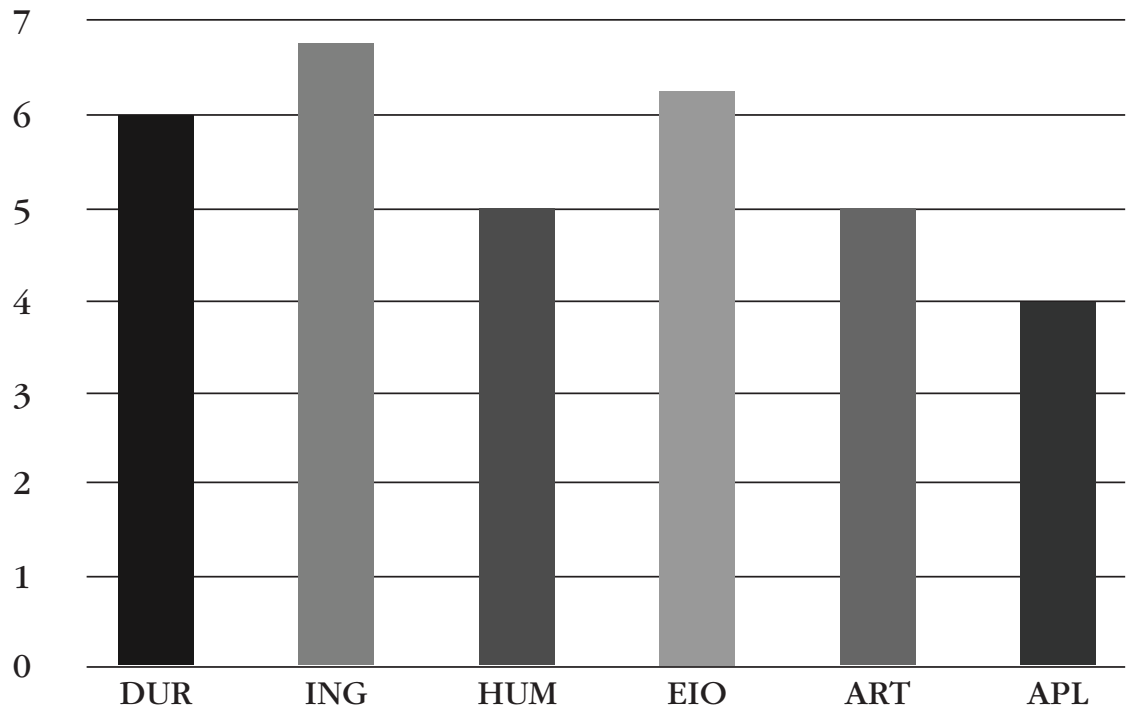

Gráfico 3. Índice de Information Literacy obtenido por área de conocimiento.

LA INTELIGENCIA ES SER INTELIGENTE

El concepto de inteligencia ha evolucionado en el tiempo y espacio. Chamovitz (2014), en el artículo titulado "Fundamentos de Inteligência, Informação e ações por Tutores em EAD" ('Fundamentos de Inteligencia, Información y acciones de los Tutores en Educación a Distancia'), ofrece una diversidad de escenarios, actores y propósitos con que se utiliza el término en diferentes áreas:

[...] en psicología, los profesionales pretenden comparar formas de aprendizaje individual y de cómo cada persona se adapta a situaciones y resuelve problemas (Goleman, 1995; Gardner, 2000); 
en Marketing y Estrategia, las empresas buscan ampliar la gama de los consumidores, o mantener la fidelidad o el liderazgo conquistado, invertir en Inteligencia de Negocios (Chandra y Gomes, 2000) e Inteligencia Competitiva (Lages y Zitz, 2005; Dos Reis Machado et. Otros., 2013); en el área de Seguridad, acciones de inteligencia pueden resultar en decisiones de impacto como en 2013, cuando fue la cancelación de la visita de la Presidenta de Brasil a Estados Unidos por cuenta de la denuncia de espionaje $y$, sin embargo, a través de su discurso en la onu, con influencia internacional (Estadão, 2013); en Tecnología de Información aplicada a los negocios, hay un creciente interés en inteligencia de negocios, por el advenimiento del Big Data (Berenitz y Silva, 2013) y de la Business Intelligence (Prado et al., 2012), también como consecuencia de la necesidad, cada vez más, el proceso y analizar la gran cantidad de datos [...] (Chamovitz, 2014: 13) [Traducción libre].

La inteligencia, por lo tanto, está difundida en una serie de componentes que deben ser interpretados y evaluados en causa y consecuencia para una toma de decisión. El comportamiento inteligente implica saber manejar estos componentes, es decir, interpretar y evaluar la información por ellos fornecida. No existe inteligencia sin información.

La reciente definición del Mainstream Science on Intelligence apunta a concebir la inteligencia como algo que depende de contextos que deben ser interpretados y evaluados en causa y consecuencia para una decisión, es decir, de un análisis de la información de la realidad para razonar, planear, pensar de manera abstracta, comprender ideas, aprender rápidamente y aprender de la experiencia.

Esa capacidad no puede ser algo programado en los términos que conocemos como "inteligencia artificial" (AI en inglés) (Boden, 1984; Trillas, 1998); lo mismo cuando nos 
preparamos para una prueba: en ambos casos, la máquina o el humano ya "saben" cómo funciona la realidad y tienen los parámetros para actuar en ella; un cambio de esa realidad crea dificultades que necesitan de nuevos parámetros. En otras palabras, el conocimiento anterior sí es extremadamente importante; sin embargo, la capacidad de comprender y de cambiar con el entorno no está plasmado en ningún lugar.

Por esta razón es que la inteligencia debe tener una buena estructura de información que depende, entre otras cosas, de tecnologías y personas que sepan interpretar, evaluar y usar la información eficientemente.

En una época en que se puede obtener información en forma digital, eso implica capacidades humanas no sólo de operar software, sino también de manejar eficientemente la información, interpretando y evaluando las fuentes y los más diversos temas para decidir en la causa y efecto. Sin embargo, operar un software despunta como uno de los componentes básicos al nivel de la lectura y la escritura en esa nueva manera de tener acceso a la información.

EL SOFTWARE Y LA INFORMATION LITERACY

El software es el que permite acceder a y operar las tecnologías digitales, básicamente es un medio de entrada y salida (inputs, outputs) de información para acciones (Brandão, 2013: 12). Es un manipulador de información y el que permite el acceso a los sistemas de información. Esto requiere de los seres humanos habilidades para manejarlos, pero también para entenderlos como un medio, no como un fin.

En la realidad investigada, un cambio de software hizo a las personas bajar su productividad, lo que identificó otro nivel de dependencia tecnológica: a pesar de las computadoras, las 
redes y los sistemas que se utilizan para el trabajo, un nuevo software ha significado problemas porque las personas estaban acostumbradas a utilizar las herramientas para actuar y no a actuar con las herramientas. Esto es sintomático y peligroso en una sociedad que ofrece varios modos de acceso y uso de la información, pero limita este potencial a ciertas herramientas, sin las cuales no puede haber otras formas de acción.

En este contexto de grandes posibilidades de información con acceso posible por muchos softwares, la Information Literacy aparece como una capacidad necesaria para la actividad de inteligencia. Es un concepto que considera la realidad de la sociedad contemporánea como una sociedad de información con organizaciones que demandan la información y el conocimiento (Cortés y Lau, 2004: 272).

El concepto destaca la competencia tradicional y única del bibliotecólogo en el abordaje crítico de la información, en su capacidad de manejar una variedad de formatos de información y en su sensibilidad para entender las necesidades de información de las diferentes categorías de usuarios (AAsL, 1998: 3).

En Estados Unidos, país de origen del término, la expresión se refiere también a las habilidades de uso de la información electrónica, donde la base de las políticas es la acción pedagógica de varios sistemas de bibliotecas escolares en aquel país. Tomando en cuenta el carácter electrónico con el que la información ha sido manipulada hoy, Caregnato (2000, p. 50) ha ampliado el término a que los estudiantes desarrollen las habilidades informacionales necesarias para interactuar en el ambiente digital, un concepto que es reforzado en la compilación de Cortés y Lau (2004). Si estas habilidades informacionales para interactuar en el ambiente digital son solamente posibles por un software, eso limita no sólo el acceso, sino también el uso eficiente de la información y las capacidades vinculadas a ella, como la inteligencia. 
De esta manera, una nueva comprensión de la inteligencia toma lugar y debe considerar el campo de la Information Literacy y de la usabilidad de software como fundamentales en la Era de la Información.

Conclusión:

UNA NUEVA COMPRENSIÓN DE INTELIGENCIA

Se debe considerar que éste es un aspecto de la inteligencia: no está sólo en el dominio de la tecnología, sino en el entendimiento de la información en diferentes sistemas, diferentes contextos y en su uso de manera eficiente. El acceso a la información vía software es un medio con el cual también se obtienen resultados de inteligencia y productividad.

Por esta razón, el software, al potencializar el uso de la información, no puede limitar las acciones humanas, especialmente las que dependen de sistemas de información a los cuales se accede por medio de diferentes recursos digitales. La investigación revela cuestiones que impactan la percepción y evaluación de la eficiencia en la productividad humana, y tiene como factor principal la información en estos sistemas de educación y trabajo. Además, se ha identificado otro nivel de dependencia tecnológica que vuelve más polémico el concepto de inteligencia.

Se añade que cualquiera que sea la forma de identificar o comprender la inteligencia, ésta debe tener en cuenta la complejidad que la Era de la Información impone en los términos que la información asume en diferentes contextos para que pueda ser utilizada eficientemente. $\mathrm{Y}$ en formato electrónico, se puede acceder a ella por medio de muchas herramientas (software) con la comprensión de la necesidad de información y no de la necesidad de la herramienta. 
La necesidad de explorar lo que implica la definición de inteligencia teniendo en cuenta la Information Literacy puede conducir a la revisión de las metodologías para detectar la inteligencia en una sociedad que todavía sigue distorsionando algunas de sus percepciones: es muy común considerar a los profesionales de la tecnología (ingenieros, analistas, programadores, matemáticos, etcétera.) como personas "inteligentes", o a organizaciones altamente automatizadas como lo mismo. La idea pura y simple de la existencia de un Sistema de Información también conduce a esta falsa concepción de que procesos eficientes - e inteligentespueden operarse solamente con esta disponibilidad.

Así es que esta propuesta para la comprensión de la inteligencia en los tiempos actuales se conforma con la definición del Mainstream Science on Intelligence en la medida en que la información se pueda usar de diferentes formas para generar un análisis de la realidad para razonar, planear, pensar de manera abstracta, comprender ideas, aprender rápidamente y aprender de la experiencia.

En estos términos, la inteligencia debe tener una buena estructura de información que depende, entre otros aspectos, de tecnologías y personas con la Information Literacy que puedan acceder, interpretar, evaluar y usar la información eficientemente. En la Era de la Información, eso también implica capacidades humanas de operar softwares para interpetar y evaluar las fuentes y los más diversos temas para tomar decisiones basadas en sus causas y efectos, y no depender de uno de ellos para tener acceso a la información. 


\section{Bibliografía}

AASL (1998). Information Power: Building Partnerships for Learning. Chicago: ALA.

Brandão, Marco (2013). Usabilidade de software como indicador para a Competência em Informação. Río de Janeiro: UFRJ / COPPE.

Boden, M.A. (1984). Inteligencia artificial y hombre natural. Madrid: Tecnos.

Caregnato, S.E. (2000). "O desenvolvimento de habilidades informacionais: o papel das bibliotecas universitárias no contexto da informação digital em rede". Revista de Biblioteconomia E Comunicação, 8, 47-55. Disponible el 2 de diciembre de 2016 en: http://eprints.rclis.org/bitstream/10760/11663/1/artigoRBC.pdf.

Chamovitz, I. (2014). "Fundamentos de Inteligência, Informação e ações por Tutores em EAD”. Revista Inteligência em Foco. Edição Especial, 1, 14-24.

Cortés, J. y J. Lau (2004). Normas de alfabetización informativa para el aprendizaje. Ciudad Juárez: Universidad Autónoma de Ciudad Juárez.

Gottfredson, L.S. (1997). "Mainstream Science on Intelligence". Intelligence, 24, 13-23.

Kumar, K. (1997). Da Sociedade pós-industrial à pós-moderna: novas teorias sobre o mundo contemporâneo. Río de Janeiro: Zahar.

Morales Campos, E. (2013). Acceso a la educación y al conocimiento a partir del derecho a la información. México: UNAM.

(coord.). Regulaciones que impactan la infodiversidad y el acceso abierto a la información en la sociedad global y multicultural. Ciudad de México: unam.

Trillas, Enrique (1998). La Inteligencia Artificial. Máquinas y personas. Madrid: Debate. 


\title{
Asociaciones e instituciones culturales: \\ el caso de las bibliotecas en México y Argentina. Trayectos, hipótesis y problemas
}

\author{
María de las Nieves Agesta \\ CER/UNS-CONICET
}

S

ostiene Alberto Manguel (2007), actual director de la Biblioteca Nacional Argentina, que en las bibliotecas el tiempo parece detenerse. Sin embargo, esta experiencia subjetiva de la temporalidad lectora convive con la historicidad de la institución que, al decir de este mismo escritor, ha cumplido un papel especial como espacio simbólico donde se concentró durante siglos el poder intelectual occidental. Asimismo, fue a partir de ellas que se articuló en gran medida el proyecto democratizador que Néstor García Canclini (2001) ha definido como uno de los cuatro movimientos básicos de la modernidad y que hizo de la confianza en la educación, la difusión del arte y los saberes especializados, la condición de una evolución racional y moral de las sociedades.

Escribir la historia de las bibliotecas en América Latina significa, por ende, reconstruir el proceso de conformación de los Estados Nacionales y de la sociedad civil, con sus cruces y tensiones, tanto como explorar las transformaciones que se produjeron en las representaciones colectivas y las prácticas 
cotidianas que vincularon a los diferentes grupos sociales con la cultura impresa en el transcurso de los años. Agencia y poder se enlazan así en el pasado de estas instituciones culturales recordándonos que, si bien las bibliotecas sugieren e imponen un orden, no deciden por sus lectores sino que ofrecen un espacio donde cada uno opta por "ser conformista o revolucionario". Es en este sentido que leer puede convertirse, como sostiene Manguel, en un acto de rebeldía, en un acto subversivo.

El proyecto posdoctoral que desarrollo en la actualidad en el IIBI-UNAM bajo la dirección de la doctora Rosa María Fernández de Zamora constituye una primera aproximación al estudio de algunos aspectos de los sistemas bibliotecarios de ambos países durante las últimas décadas del siglo XIX y las iniciales del siglo xx, que tiene como principal objetivo la reconstrucción de los tránsitos bibliográficos entre uno y otro. Aunque el avance de la investigación se halla en un estado aún incipiente, el presente trabajo tiene como finalidad compartir el trayecto teórico y empírico que me ha conducido a la formulación de las hipótesis y los problemas que orientan este plan, y que me permiten plantear interrogantes no previstos inicialmente a que anticipan la potencialidad del enfoque comparativo entre ambos modelos.

Dado que mi formación específica en historia y sociología de la cultura imprime un sesgo particular a la perspectiva desde la cual se observan las bibliotecas en cuestión, es uno de los propósitos esenciales de mi estadía adquirir las herramientas teóricas y metodológicas que ofrece la bibliotecología para abordar la historia de estas instituciones, sus formas de organización y la conformación de sus patrimonios bibliográficos. Asimismo, en tanto mis estudios han estado ligados a la reconstrucción del pasado de un espacio local del Interior de la Argentina, se pretende avanzar sobre una dimensión comparativa que permita asumir una visión 
más integrada de las experiencias latinoamericanas. De este modo, las entidades bonaerenses que constituyen mi principal objeto de análisis podrán ser abordadas en su singularidad sin caer en miradas exclusivamente regionalistas mediante la inserción de los problemas específicos en el marco de otros más amplios de carácter nacional y continental.

DE LAS REVISTAS A LAS BIBLIOTECAS:

EL TRAYECTO DE LA INVESTIGACIÓN

Como señalé antes, hasta el momento mis puntos de vista han estado atravesados por las preocupaciones de la historia de la cultura y por la reflexión en torno al problema de la escala. Desde esta doble matriz, he abordado diversos objetos e instituciones que me han conducido al estudio de las bibliotecas. Desde 2004, en mi tesis de maestría (Agesta, 2009) y desde 2009 en mi investigación doctoral (Agesta, 2016), las revistas culturales editadas entre 1902 y 1907 de Bahía Blanca, una ciudad intermedia situada al sudoeste de la provincia de Buenos Aires, fueron el núcleo principal de mi trabajo. A partir de ellas, me introduje en otras cuestiones atinentes a la organización social y las prácticas culturales de la época, en particular, en aquellas referidas a la conformación del grupo letrado que llevó adelante estos proyectos editoriales modernos, que modificaron la composición y las prácticas de la élite mediante la diversificación de las bases sociales de su legitimidad. En este contexto, adquirió una relevancia especial la creación de nuevas instituciones dedicadas exclusivamente a la producción y difusión de la cultura pero también su articulación con distintas entidades de la burguesía local que, al igual que las de extracción popular, se habían multiplicado desde fines de la centuria anterior. 
De este modo, mi investigación experimentó un desplazamiento de la historia cultural a la historia social y una ampliación temporal que extendió mi término a quo hasta las últimas décadas del siglo XIX. El análisis de las asociaciones culturales bahienses entre 1882 y 1927 a fin de reconstruir el proceso de ampliación y de diversificación de la élite y el rol que en ella ocuparon los grupos letrados fue el nuevo eje de trabajo, así como su vínculo con las demás instituciones culturales de la zona.

BIBLIOTECA POPULAR Y BIBLIOTECA PÚBLICA, DOS MODELOS ALTERNATIVOS

Las bibliotecas populares del sudoeste bonaerense constituyeron un claro ejemplo de articulación entre formaciones e instituciones en tanto que surgieron de agrupaciones civiles que llevaron adelante estos proyectos de promoción de la cultura letrada. En este sentido, es de mi interés abordar tres bibliotecas creadas entre 1882 y 1930: la Biblioteca Popular Bernardino Rivadavia de Bahía Blanca (1882), la Biblioteca Popular Sarmiento de Tres Arroyos (1899) y su homónima de Coronel Suárez (1915), que resultan comparables desde el punto de vista institucional y geopolítico. Esta consonancia no implica, por supuesto, desconocer las especificidades que distinguieron estas experiencias, aunque sí supone articular las realidades locales en un constructo regional sustentado por la existencia de redes de sociabilidad y de intercambio de bienes culturales.

El calificativo "popular" con que fueron creadas, las distingue como parte de un proceso más general que caracterizó la conformación del sistema bibliotecario argentino desde sus inicios. En efecto, a diferencia de países como México, donde las bibliotecas públicas se convirtieron en vectores 
de democratización de la cultura y en medios a partir de los cuales canalizar las demandas de extensión del beneficio de la educación al pueblo, en Argentina este rol fue ocupado por las bibliotecas populares. Junto a la escuela pública, ellas constituyeron las bases sobre las cuales se asentó el proyecto de educación nacional llevado adelante por el Estado argentino que, sin embargo, confió parte de sus prerrogativas a la sociedad civil en expansión. Sin dudas, mucho tuvo que ver en la configuración de este sistema la magnitud y la proyección pública de la figura de Domingo Faustino Sarmiento, quien fue presidente de Argentina entre 1868 y 1874, y centró gran parte de sus esfuerzos en la promoción de la educación mediante la creación de nuevas escuelas y colegios nacionales, la compra de materiales y libros, la renovación del modelo pedagógico a través de la introducción del normalismo y, por supuesto, del fomento de las bibliotecas a fin de estimular la expansión de la lectura. ${ }^{12}$

Personaje polémico y provocador, Sarmiento fue sumamente importante tanto para el avance legislativo y material del sistema bibliotecario, como para su conceptualización. Valga mencionar que, durante su gestión presidencial, las bibliotecas pasaron de 64 a 125, cuando se extendieron a buena parte de las provincias. Fue a partir de sus viajes a Estados Unidos entre 1847 y 1865 que desarrolló su idea de estimular las bibliotecas populares de acuerdo con el modelo de los Clubes de Lectores concebidos por Benjamin Franklin en 1727 en la ciudad de Filadelfia, y de las experiencias estadounidenses en las zonas rurales y en las ciudades. Tal como sostenía en su texto de 1840 "Espíritu de asociación", la iniciativa privada debía preceder al accionar gubernamental

12 Sobre la figura de Domingo Faustino Sarmiento en relación con el desarrollo de las bibliotecas populares en la Argentina, véase Planas (2008 y 2012). 
dado que, de acuerdo con su perspectiva, los pueblos que gozaban "del inestimable bien de la libertad" eran aquellos donde proliferan las asociaciones. Por ello, se volvía necesario promover la formación de "sociedades para fomentar la lectura de libros útiles, la difusión de los diarios entre los ciudadanos y la instrucción primaria en todas las clases de la sociedad" y así constituir bibliotecas en "cada aldea, villa o ciudad" (Sarmiento, 1939: 11-14).

Como indica Javier Planas, fundar una biblioteca de esta forma no sólo significaba crear un espacio para el préstamo de libros sino que suponía, en principio, organizar una entidad vecinal básica: proponer la idea, buscar adeptos, participar de la recaudación inicial, debatir los estatutos y los reglamentos, escoger un lugar físico y amueblarlo, asignar responsabilidades, armar la lista de los libros que desean adquirir, etcétera, y construir así un sentimiento de pertenencia comunitaria. En este primer momento, la responsabilidad de la expansión bibliotecaria quedaba casi con exclusividad en manos de la sociedad civil y, más específicamente, de sus élites, dado que el Estado se hallaba en pleno proceso de institucionalización y, por ende, no estaba en condiciones de asumir la constitución de una red de bibliotecas financiadas completamente por las arcas públicas.

Aunque sosteniendo la importancia de la iniciativa privada, más tarde Sarmiento fue matizando estas ideas iniciales para proponer un sistema de bibliotecas en el que deberían combinarse el esfuerzo público y el privado. El Estado funcionaría, en este marco, como ente regulador a la vez que como fuente complementaria de financiamiento a partir de la implementación de una política de subsidios. Fue así que en 1870, durante su presidencia, se promulgó la Ley 419 (reemplazada en 1989 por la 23.351), por la que se creó la Comisión Protectora de Bibliotecas Populares. A través suyo, el Estado tenía la misión de promocionar, apoyar y supervisar las bibliotecas 
dejando a cargo de los ciudadanos dos aspectos sustanciales: la fundación y la administración. El éxito de la normativa fue indiscutible y así se deduce del notable crecimiento del número de bibliotecas populares que se produjo hasta 1876 , fecha en que fue derogada la ley. ${ }^{13}$

Las instituciones bonaerenses formaron parte de este movimiento más amplio y, en consecuencia, su estudio permite reconstruir a partir de la dimensión microanalítica los avatares del proceso de configuración del sistema bibliotecario argentino desde sus inicios. En efecto, en los tres casos se trataba de bibliotecas surgidas a partir de sociedades civiles autónomas (Asociación Bernardino Rivadavia, Centro Recreativo del Comercio y Logia Masónica Abnegación) que - públicas por su acceso pero no por su gestión y financiamiento - se hallaban abiertas al público pero eran dirigidas y sostenidas por sus socios, que otorgaban a la cultura un rol fundamental en el desarrollo civilizatorio.

Las particularidades de las localidades examinadas, marcadas por una fundación relativamente tardía y un crecimiento acelerado vinculado a una inserción exitosa en el modelo agroexportador a partir de la expansión de la red ferroviaria, las convirtieron, de acuerdo con la definición de Mariano Plotkin y Eduardo Zimmerman (2012), en "zonas grises" donde la intervención estatal en la institucionalización de la cultura resultó más limitada y asistemática que en otros lugares del país. En este contexto, las élites locales, reunidas en entidades y agrupaciones de distinto tipo, como las bibliotecas, asumieron un rol decisivo en el desenvolvimiento de los procesos culturales, aunque siempre reclamando una intervención más activa por parte del Estado.

13 De diez bibliotecas populares que existían en 1870 , se pasó a 106 en 1872 , 156 en 1874 y doscientas en 1876. 
En este sentido, es posible formular una primera hipótesis comparativa entre la realidad argentina y la mexicana según la cual las diferencias que evidencian ambos sistemas bibliotecarios encuentran sus orígenes en una concepción distinta de las relaciones entre Estado, sociedad civil y cultura. Aunque unidos por la confianza ilustrada en la cultura letrada como instrumento de transformación social y por un cierto reformismo liberal que compartieron las élites dirigentes de las naciones latinoamericanas, mientras en México el gobierno revolucionario (Quintana Pali, Gil Villegas y Tolosa Sánchez, 1988) asumió casi íntegramente un amplio proyecto bibliotecario donde la biblioteca pública fue considerada el elemento fundamental de la educación del pueblo, en Argentina este proceso fue compartido con la sociedad civil en la cual el Estado delegó parte de sus prerrogativas en materia de educación. Fue entonces la biblioteca popular y no la pública el eje del sistema bibliotecario en el país sudamericano. Si bien aún queda mucho por indagar en este sentido, podemos conjeturar que dicha particularidad argentina se debió tanto a la impronta sarmientina antes mencionada y la conformación de una esfera pública activa, como a la relativa precocidad de la implantación de dicho proyecto que provocó que su implementación no pudiera ser asumida en su totalidad por un Estado que se hallaba todavía en proceso de conformación y de consolidación.

LOS TRÁNSITOS BIBLIOGRÁFICOS EN LA CONFORMACIÓN DE LOS CATÁLOgos bonaerenses. El caso de la Biblioteca Popular Bernardino Rivadavia de Bahía Blanca

Hasta el momento y por razones de tiempo, mis investigaciones se han limitado a indagar la formación, la composición y el funcionamiento de la Biblioteca Popular Bernardino Rivadavia 
de Bahía Blanca. Esta entidad cultural, la más antigua de la ciudad, surgió como una iniciativa de la Asociación del mismo nombre creada en 1882 por un grupo heterogéneo de ciudadanos conspicuos. La misión pedagógica de alcance popular que se atribuía a la Biblioteca Rivadavia enunciaba, desde su misma fundación, un compromiso con el proyecto nacional de alfabetización y formación de los ciudadanos y venía a suplir, en cierta medida, las carencias del propio Estado en materia educativa. En este sentido, su existencia estuvo marcada por la tensión entre la reivindicación de autonomía y los reclamos de apoyo gubernamental a través de la política de subsidios.

El estudio sobre esta biblioteca y su asociación se ha realizado por ahora a partir de tres líneas de investigación. La primera atañe a sus aspectos sociales e institucionales y resulta complementaria con otros estudios previos sobre los procesos de profesionalización de los grupos letrados en la ciudad. Dado que su accionar como "animadores culturales", deseosos de crear las condiciones para el intercambio intelectual en una localidad provinciana los llevó a involucrarse en diferentes proyectos culturales (Martínez, 2013: 169-180), es ineludible rastrear su presencia en la gestación, dirección y administración de la biblioteca fundada por una de las asociaciones más antiguas del lugar. La exploración puso de relieve, por un lado, los nexos y las contradicciones entre las normas regulatorias y las formas efectivas de funcionamiento y, por el otro, las dinámicas asociativas en regiones relativamente alejadas de los nodos de producción y consumo intelectual. De este modo, se habilitó una reflexión sobre las tensiones entre lo estatal y lo privado en materia cultural, así como sobre las representaciones del Estado y el rol que sostuvieron los sectores dirigentes en los espacios considerados (Agesta, 2016b). 
Un segundo eje se centra en la dimensión ideológica de la institución a la que se consideraba parte del proyecto modernizador y civilizatorio del país. En efecto, la confianza en el libro y la lectura como motores del progreso, fundamentada en el pensamiento ilustrado, sustentó las políticas de alfabetización impulsadas a partir del siglo xIX en los nacientes Estados latinoamericanos e impulsó la creación de bibliotecas populares como una muestra de la vocación pública de las élites. De acuerdo con ello, se han examinado las actividades de promoción y de divulgación cultural llevadas adelante por la Asociación, encaradas por una dirigencia que se concebía destinada a dirigir el rumbo de los asuntos públicos y cuyo deber era encabezar el progreso moral e intelectual de sus compatriotas. Este espíritu de reforma cultural formó parte de un proyecto más extenso que incluía, además, la cuestión social, la modificación del sistema político sobre bases legalistas y la reformulación del rol del Estado. Mediante los programas implementados, la asociación se transformó tanto en el núcleo de una intensa labor de difusión lectora y de extensión cultural, como en un centro irradiador y difusor de modelos intelectuales y en una plataforma de visibilización y de consagración social para los miembros de las sucesivas comisiones que se ocuparon de su dirección durante el período considerado (Agesta, 2016c).

La última línea de investigación desarrollada es de tipo intelectual o literario y aborda, mediante metodologías cuantitativas y cualitativas, la conformación y las transformaciones del material bibliográfico y hemerográfico que componía sus fondos (Agesta 2014 y 2012). De esta manera, se pretende analizar la importancia de la institución en la definición del gusto lector y la difusión de corrientes y modas literarias, así como su rol de mediadora entre los proyectos e intereses letrados y los de los usuarios. A modo de conclusión provisoria, 
puede afirmarse que se ha observado una modificación relevante en la composición de los catálogos editados entre 1900 y 1932. Durante todo el periodo, se evidencia una clara preferencia por los autores románticos y realistas/naturalistas, así como un predominio de la literatura de aventuras y el folletín. Sin embargo, hacia 1916 comenzaron a sumarse obras de autores argentinos y latinoamericanos como Ernesto Quesada, Carlos Bunge, Manuel Ugarte, Ricardo Rojas, Hilario Ascasubi, José Hernández, Estanislao del Campo, Marcos Sastre, Carlos Roxlo, Andrés Bello, Eugenio Cambaceres, Evaristo Carriego y Roberto Giusti, además de las de los miembros de la Generación del 98 española como Pío Baroja, Felipe Trigo, Jacinto Benavente, Miguel de Unamuno, Valle Inclán y Eduardo Zamacois, entre otros. Esta tendencia se acentuó en el catálogo de 1925 que denota una presencia creciente de autores hispanoamericanos, entre ellos mexicanos.

En relación con ello, se ha formulado una segunda hipótesis que sostiene que dichas transformaciones se debieron a la articulación de los intereses locales, cada vez más volcados a la búsqueda de una identidad latinoamericana y al tendido de redes con otros países del continente, específicamente con los Estados preocupados por la puesta en marcha de una activa política de difusión cultural. En efecto, en el caso de México resulta fundamental la política exterior desarrollada durante el ministerio educativo de José Vasconcelos, cuyos objetivos principales fueron divulgar la importante obra educativa y cultural impulsada por el Gobierno de la Revolución y concretar el viejo ideal bolivariano de "dignificar y unificar culturalmente a los pueblos iberoamericanos por medio de la difusión de lo mejor de su obra y de su pensamiento" (Quintana Pali, Gil Villegas y Tolosa Sánchez, 1988: 219), Esta política afectó directamente la composición de los acervos bibliográficos argentinos, tal como se deduce, por ejemplo, a partir del 
convenio firmado por Enrique González Martínez con la Comisión Protectora de Bibliotecas Populares para la distribución de publicaciones mexicanas en la red de bibliotecas bajo su jurisdicción (Yankelevich, 2007: 83-104). Aunque queda aún por hacer un estudio pormenorizado de los catálogos en función de las nóminas de libros enviados, puede conjeturarse, a partir de la creciente presencia de autores de esta nacionalidad en la Biblioteca Rivadavia, que dicha iniciativa tuvo una repercusión importante en la transformación del campo de lecturas disponible en el interior del país.

\section{Conclusiones}

A pesar de hallarse aún en un estado embrionario, el presente proyecto de investigación confirma la necesidad de avanzar en el desarrollo de los estudios comparativos latinoamericanos en materia de historia cultural. El caso de las bibliotecas permite, de hecho, una primera aproximación a problemas comunes como el rol diferencial asumido por el Estado mexicano y el argentino en la conformación de las tempranas agendas culturales de ambos países, y el papel que asignaron al libro como instrumento de difusión y de propaganda nacionales. La articulación con investigaciones previas hace posible insertar el pasado bibliotecario en un marco más amplio que reafirma la noción de una historia integrada donde lo social, político, ideológico, económico y cultural aparezcan imbricados en una trama de determinaciones mutuas. Por otra parte, habilita una reflexión metodológica al plantear el examen minucioso del devenir de algunas bibliotecas de una provincia argentina como punto de partida para la construcción de una historia de redes y tránsitos culturales intracontinentales. 
El análisis micro efectuado tanto a través de metodologías cuantitativas como cualitativas se convierte, así, en punto de partida para abordar problemas generales a una escala territorial más amplia.

La potencialidad de la comparación entre los procesos nacionales podrá ser explotada, entonces, a condición de enlazar los estudios sobre entidades particulares con los referidos a las políticas culturales estatales y al accionar de grupos e individuos comprometidos con el proyecto educativo y civilizatorio de la modernidad.

\section{Bibliografía}

Agesta, M. de las N. (2016). Páginas modernas: revistas culturales, transformación social y cultura visual en Babía Blanca, 1902-1927. Bahía Blanca: EdiUNS.

(2016b). "Modernismo de gente bien. Asociacionismo intelectual y cultura de élite en Bahía Blanca (1882-1930)". En Actas de las VJornadas de Historia Social. Córdoba: Red Internacional de Hist. Social / cEH Prof. Carlos Segreti.

(2016c). "A puertas abiertas. La Asociación Bernardino Rivadavia de Bahía Blanca: reformismo, distinción social y configuración urbana (1882-1930)". Estudios del ISHiR [en prensa].

(2014). "Literatura en los márgenes. El Modernismo en una ciudad del interior argentino (Bahía Blanca, 1900-1930)". Journal of Hispanic Modernism, 5, 152-169. Disponible en: http://jhm. magazinemodernista.com/2014/03/06/issue-5/.

(2012). "Rubén Darío en la 'ciudad de la mar'. La visita del poeta nicaragüense a Bahía Blanca y su impronta en la constitución del campo intelectual local a principios del siglo xx". En $I X$ 
Jornadas del Departamento de Historia. Mar del Plata: Facultad de Humanidades de la Universidad de Mar del Plata.

(2009). Proyecciones en imágenes: prensa ilustrada y cultura visual en el proceso de modernización de Babía Blanca (19091910). Buenos Aires: Idaes-unsa. Tesis de maestría. Disponible en: http://www.mediafire.com/?hdlocatevvwei19.

García Canclini, N. (2001). Culturas híbridas. Estrategias para entrar y salir de la modernidad. Barcelona: Paidós.

Manguel, A. (2007). "La lectura es un acto de rebeldía". La Voz on line. Disponible en: http://archivo.lavoz.com.ar/nota.asp?nota_ id $=48208$.

Martínez, A.T. (2013). "Intelectuales de provincia: entre lo local y lo periférico". Prismas. Revista de Historia Intelectual, 17 (2), 169-180.

Pasolini, R.O. (1997). "Entre la evasión y el humanismo. Lecturas, lectores y cultura de los sectores populares: La Biblioteca Juan B. Justo de Tandil. 1928-1945". Anuario IEHS "Prof. Juan C. Grosso", 12, 373-401.

Planas, J. (2012). "Libros, lectores y lecturas: las bibliotecas populares en la Argentina entre 1870 y 1876". La Plata: Universidad Nacional de La Plata. Tesis de maestría. Disponible en: http:// sedici.unlp.edu.ar/bitstream/handle/10915/26138/Documento_completo__.pdf?sequence=1.

(2008). Discurso sobre bibliotecas populares: Sarmiento. La Plata: Universidad Nacional de La Plata. Tesina de grado. Disponible en: http://www.memoria.fahce.unlp.edu.ar/tesis/te.1138/ te.1138.pdf.

Plotkin, M. y E. Zimmermann (comps.) (2012). Los Saberes del Estado. Buenos Aires: Edhasa.

Quintana Pali, G., C. Gil Villegas y G. Tolosa Sánchez (1988). Las bibliotecas públicas en México: 1910-1940. México: Dirección General de Bibliotecas. 
Quiroga, N. (2003). "Lectura y política. Los lectores de la Biblioteca Popular Juventud Moderna de Mar del Plata (fines de los años treinta y principio de los cuarenta)". Anuario IEHS "Prof. Juan C. Grosso", 18, 449-474.

Sarmiento, D.F. (1939). "El espíritu de asociación" [1841]. En Páginas selectas de Sarmiento sobre Bibliotecas populares (11-14). Buenos Aires: Comisión Nacional de Homenaje a Sarmiento.

Vignoli, M. (2015). Sociabilidad y cultura politica. La Sociedad Sarmiento de Tucumán, 1880-1914. Rosario: Prohistoria.

Yankelevich, P. (2007). "México-Argentina. Itinerario de una relación 1910-1930". Tzintzun. Revista de Estudios Históricos, 45, 83-104. 
Colaboración entre la bibliotecología y los sectores productivos y económicos. Instituto de Investigaciones Bibliotecológicas y de la Información/UNAM. La edición consta de 100 ejemplares. Coordinación editorial, Carlos Ceballos Sosa; formación editorial y corrección de pruebas, Paola Sanabria; corrección de pruebas, Valeria Guzmán González. Fue impreso en papel cultural de $90 \mathrm{~g}$. Se terminó de imprimir en el mes de septiembre de 2017 en los talleres AGYS Alevin, S.C., retorno de Amores no. 14, colonia Del Valle, c.p. 03100, delegación Benito Juárez, Ciudad de México. 